Anna Sroka / Fanny Castro-Rial Garrone / Rubén Darío Torres Kumbrián (eds.)

\title{
Radicalism and Terrorism in the 21st Century
}

Implications for Security 


\section{Anna Sroka / Fanny Castro-Rial Garrone / Rubén Darío Torres Kumbrián (eds.)}

\section{Radicalism and Terrorism in the 21st Century}

This book addresses the issues of radicalism and terrorism, which are of exceptional importance and relevance in contemporary society. Each of the two phenomena are analyzed from a multidisciplinary perspective. The book contains articles which explore legal, political, psychological, economic and social aspects of radicalism and terrorism. A portion of the contributions are of a theoretical nature, they constitute an attempt at constructing analytical frameworks for studies on the two phenomena. There are also studies of particular cases, such as radicalism in Poland and in Spain, as well as within the European Union as a whole. This collective work is a response to the need for analyses of two issues which are increasingly responsible for determining the level of security which characterizes the contemporary world.
The Editors

Anna Sroka is Assistent Professor and head of the Graduate Programme in Security Studies at the University of Warsaw, Institute of Political Science. She is also a member of the board of the IPSA "Quality of Democracy" scientific committee, coordinator of the Polish-Spanish Scientific Research Network, and a member of the ECPR Executive Committee.

Fanny Castro-Rial Garrone received her $\mathrm{PhD}$ in law from the Complutense University of Madrid. She is a permanent Lecturer of IS International Public Law and International Relations, director of the University Institute for Domestic Security Research, and coordinator of the UNED Law School Security Masters and professor at the Spanish School of Diplomacy.

Rubén Dario Torres Kumbrian received his $\mathrm{PhD}$ from the Doctoral Programme of Community law and European Union, Centers for European Studies and PhD at Doctoral Program in Employment, Industrial Relations and Social Dialogue in Europe at the Complutense University of Madrid. He is Professor and Director of the Department of Social Work, Faculty of Law, UNED. 
Radicalism and Terrorism in the 21st Century 


\section{STUDIES IN POLITICS, SECURITY AND SOCIETY}

Edited by Stanisław Sulowski

Institute of Political Science of the University of Warsaw

VOLUME 9 
Anna Sroka / Fanny Castro-Rial Garrone /

Rubén Darío Torres Kumbrián (eds.)

\section{Radicalism and Terrorism in the 21st Century}

Implications for Security 


\section{Bibliographic Information published by the Deutsche Nationalbibliothek}

The Deutsche Nationalbibliothek lists this publication in the Deutsche Nationalbibliografie; detailed bibliographic data is available in the internet at http://dnb.d-nb.de.

An electronic version of this book is freely available, thanks to the support of libraries working with Knowledge Unlatched. $\mathrm{KU}$ is a collaborative initiative designed to make high quality books Open Access for the public good. More information about the initiative and links to the Open Access version can be found at www. knowledgeunlatched.org.

Open Access: The online version of this publication is published on www.peterlang.com and www.econstor.eu under the international Creative Commons License CC-BY-NC-ND 4.0. Learn more on how you can use and share this work: https://creativecommons.org/licenses/by-nc-nd/4.0/.

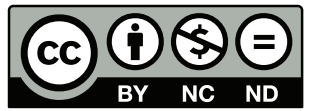

All versions of this work may contain content reproduced under license from third parties. Permission to reproduce this third-party content must be obtained from these third-parties directly.

This publication was financially supported by the Institute of Political Sciences of the University of Warsaw, Poland, as well as by Faculty of Law of the National Distance Education University (UNED), Spain.

ISSN 2199-028X

ISBN 978-3-631-67542-7 (Print)

E-ISBN 978-3-653-06974-7 (E-PDF)

E-ISBN 978-3-631-70638-1 (EPUB)

E-ISBN 978-3-631-70639-8 (MOBI)

DOI 10.3726/b10680

(C) Peter Lang $\mathrm{GmbH}$

Internationaler Verlag der Wissenschaften

Frankfurt am Main 2017

Peter Lang Edition is an Imprint of Peter Lang GmbH.

Peter Lang - Frankfurt am Main · Bern · Bruxelles · New York ·

Oxford $\cdot$ Warszawa $\cdot$ Wien

This publication has been peer reviewed.

www.peterlang.com 


\section{Table of Contents}

Introduction

Stanisław Sulowski

Counter-Terrorism: Correlating Security and Freedom

Fanny Castro-Rial Garrone

An Updated Approach to the Study of Terrorism.

Sebastian Wojciechowski

Reasons of Contemporary Terrorism. An Analysis of

Main Determinants

Pablo de Diego Ángeles and Rubén Darío Torres Kumbrián

An Approach to the Economic and Financial Dimensions of

Radicalization and Terrorism

Jesús Pérez Viejo and Ángeles Martínez Boyé

An Analysis of the Psycho-Social Factors Involved in

Jihadist Radicalization Process and Terrorist Violence.

Anna Potyrała

Islamic State - Disputed Statehood.

Hallar Abderrahaman Mohamed

Woman and ISIS: Social Diagnosis and Interventions.....

Anna Sroka and Katarzyna Trofimowicz

Terrorism and Political Radicalism in the Security Strategies of

Poland and Spain versus Public Opinion

José María Blanco Navarro

The Fight against Jihadism in Spain Special Mention to the

Spanish Civil Guard

Damian Szlachter and Piotr Potejko

Religious Extremism among Islam Believers Living in

Poland - the Results and Conclusions of the Research 
Andrzej Misiuk and Magdalena Dobrowolska-Opała

Terrorist Threats and Mass Events

Claribel de Castro Sánchez

Security, Migrant Flows, and Terrorism in the European Area of

Freedom, Security and Justice

Teresa Marcos Martín

Legal Instruments and Specific Actions in the EU's Fight against Terrorism.

Juan Manuel Goig Martínez and María Acracia Núñez Martínez

The Islamic State's Political Organization. The Political Impact of

Jihadist Terrorrism: Consequences in the European Union. 261

Daniel Przastek and Elżbieta Borowska

Theme of Terrorism in Art of the $21^{\text {st }}$ Century

Notes on Contributors 


\section{Introduction}

This book can be described as the result of an ongoing research project within the International Permanent Seminar for Homeland and Foreign Security in the European Union in the era of Globalization. This event has been organized by the Institute of Political Science at the University of Warsaw and the Universitarian Institute for Homeland Security Research (Civil Guard and the Spanish Open University UNED), the Spanish-Polish Network for Scientific Research and the Legal Practice School at the UNED Law School.

Our purpose is to offer the reader the less-known comprehensive and unavoidable keys to understanding the violent radicalization and terrorism that has been labelled by the media, and a considerable portion of the scientific literature, as "Jihadism." We cannot avoid pointing out that both the Spanish and Polish authors of this book, as well as the institutions which have promoted it, know and accept that the concept of "Jihad" rejects the current terrorist brutality perpetrated in its name, as well as in the name of Islam and Muslims.

According to statistics, approximately thirteen million Muslim citizens currently belong to a European Union Member States. If we take into account the entire European territory, Muslim communities make up a population segment of up to forty four million human beings.

A contextualized and precise reading of statistical data allows us to conclude that the millions of European Muslims follow a normalized social trend that rejects violent radicalization and terrorism of any denomination, and above all, the one committed in the name of Islam, the Jihad and Muslims.

Many among us are determined to eradicate the personalization of the ideology of hatred. To achieve this goal, European political and social leaders should always be assisted by Islamic religious leaders, who preach a moderate interpretation of Islamic scripture, effectively severing the link between the concept of Holy War and terrorism.

We must abandon the commonly used terms, such as "Islamic terrorism" or "jihadist terrorism," since it is important to avoid the mistake of stigmatizing a religious belief such as the real Islam. We believe that repeated use of those terms could play into the argumentation of jihadist terrorists, thus turning the situation in their favor and creating the counterproductive side effect of reinforcing these groups' false premise of western hostility toward Islam, which would support the intent of presenting themselves as victims of the western world for their beliefs. The very essence of democratic values in a multicultural society supports and 
defends freedom, a freedom which is used perversely with criminal intent, lacking any true religious purpose, promoting a lawless indoctrination leading to terrorist acts, which are perpetrated against the citizens of a democratic society under the shelter of its established liberties.

In his speech before the Summit on Countering Violent Extremism, Barack Obama stressed the urgency of specific codification, not as an issue of political correctness, but as a strategic and operational priority. This is considered an unavoidable option, since certain risks derived from an inadequate codification are the wrongful characterization of Islam as a synonym for terrorism, contributing to the spread of islamophobia and as a consequence, the risk of neutral or favorable reactions and attitudes of moderate Muslims toward terrorists.

The use of terms such as Jihad, with the only definition being "holy war", or Salafism as a synonym for jihadist terrorism, among others, entails accepting and legitimizing the ideologists' digital narrative supporting violent and terrorist radicalism. Those ideologists preach an exemplary action according to Islam principles, but in truthfulness, they digitally falsify their religion.

This work is encased within this perspective, analyzing the impact of globalization on the creation of new forms of terrorism and radicalization, testing the capacities of States, international organizations and the scientific community.

This research delved into the European scene, where jihadism constantly defies domestic and foreign security strengths, increases actions within the European Union, and strains the already delicate balance between security and fundamental rights or individual liberties.

The narrative resulting from this research emphasizes how the conceptual differentiation between Domestic and Foreign Security regains new and more precise meaning within the context of global strategies designed and implemented by the UN and the European Union. Strategic and operational multilateralism, together with a cross-disciplinary scientific research, the transfer of knowledge and the extrapolation of verified good practices, are imperative priorities in interventions against terrorism and radicalization - above all, in operational areas related to anticipation and prevention.

In the European Union, the risks derived from radicalization and terrorism are attributed to a geopolitical context of conflict, economic crisis, and a surge of ideologies of hatred. Along the Mediterranean, the causes are linked to the Arab spring, the definition of Libya as a failed state, the fragmentation of Syria and Iraq in favor of the expansion of Daesh, and the survival of Al Qaeda and an extensive network of its subsidiaries. In eastern Europe, the Russian annexation of Crimea and the Ukrainian war design a stage of crisis and instability. The terrorist attacks 
in Madrid, London, Paris, and Copenhagen confirm that the European Member States constitute the main staging area for global jihadism.

Within the frame of this comprehensive context, Polish and Spanish authors enlist on an analytic immersion hoping to contribute from the respective fields of Law, Political Science, and Social Work to the knowledge and understanding of a pivotal issue of our time.

Fanny Castro-Rial Garrone 



\section{Stanisław Sulowski \\ Counter-Terrorism: \\ Correlating Security and Freedom}

\section{Introduction}

The 9/11 terrorist attacks in New York and Washington, which came as a complete surprise to the USA and the countries of Europe, indubitably represent a turning point in the political and academic discourse on internal and international security. A number of European states have experienced acts of terrorism in the 1970 s - these were acts of an endemic nature. At the turn of the twenty-first century, these crises subsided into the past, attracting insufficient attention in the public realm. However, the new threat facing the US, especially its domestic security - as the country, at that time, lacked experience in this field, and coupled with the shock - instilled a sense of helplessness among its political elites and the wider public. This led the US President to announce that his country was in a state of war with the new terrorism, the now infamous "War on Terror." In a word, this was a sign that a new form of threat to the security of the state and its public was faced by the rule of law democracies and they lacked the knowledge on how to deal with it.

What is more, the 9/11 attacks made it abundantly clear that, in the globalized and unilateral world we have today, the spheres of internal and external security interweave and are closely linked together. This brought a clear message to American decision-makers: matters of security and combating terrorism cannot be solved with measures hitherto applied. A new type of menace requires a new response. President Bush postulated that this new form of threat requires a new paradigm of thinking on the right to war. ${ }^{1}$ The terrorist attacks in Madrid in 2004 and in London the following year prompted individual countries to step up efforts to find solutions to the growing danger, placing that subject on the top of their political agenda.

1 Memorandum from the US President G. Bush, Human Treatment if Taliban and al Qaeda Detainees, available at http//www.fidh.org/IMG/pdf/memo11, accessed 21 December 2015. 


\section{Security and Terrorism Discourse in the Wake of 11 September 2001}

As already mentioned, the terrorist attacks of 11 September 2001 marked a significant watershed in academic research. Prior to these attacks, the investigation of terrorism was the sole domain of expert centers, government administration advisory bodies and the secret service while the main focus was on leftist, ethnic and sectarian terrorism. The terror attacks of 2001 shifted attention to the problem of international terrorism, generating increased funds for research, including academic investigation.

At the same time, the September attacks represent a turning point in the history of international terrorism. Violent, fear-inspiring attacks are, after all, an old phenomenon, but it is only the $9 / 11$ that maps out a new stage on the path of its growth. The specific nature and size of these attacks introduced into public and academic discourse a new type of terrorism, one that is linked to Islam. Thus, after 2001 Islamic terrorism becomes an object of attention. Over the years, it gained a strong religious legitimation, which was created - according to Gilles Kepel - in the process of grass-roots "re-islamization" across the Arabic world and in the Islamized areas of Western Europe. ${ }^{2}$ It must be added, of course, that this constitutes an abuse of Islamic religion and a highly instrumental approach to its religious tenets.

The phenomenon of Islamic terrorism is partly a consequence of global modernization which sees a clash between the traditional life-style (based on religion) and modernity (identified primarily with the Western culture). What is new about this type of terrorism is that it is not a method of reaching specific political goals but rather a strategy against a specified enemy. Certain new and hitherto unseen features seem to define it. Firstly, it is motivated by a strong religious message. Secondly, the perpetrators include mainly suicide bombers bent on killing and maiming the most number of people. Thirdly, they have at their disposal an effective system for generating vast funds. Fourthly, and most importantly, they have a new organization structure that is a flexible and global network.

The post 9/11 terrorist attacks had a mobilizing effect on Western states to undertake various counter measures. Among them were primarily the moves to change internal law in respect of state security and cooperation with other countries in order to combat terrorism. At this time, an international legal system comprising of procedures and institutions has been developed to safeguard against and to fight terrorism. It is made up of rules and regulations within the UN, the

2 G. Kepel, La revanche de Dieu. Chretiens, juifs et muslumans la reconquwete du Monde, Editions du Seuil, Paris 2003. 
Council of Europe and the European Union. What makes these regulations unique is the fact that they stress the need to comply with the basic standards in human rights protection, even with regard to the perpetrators of such acts. ${ }^{3}$ However, despite the considerable legal output of the international community tackling the new threats a single definition of terrorism acceptable to most states is yet to be written. The lack of such a definition makes the undertaking of counter-terrorism measures by states more difficult, especially where it concerns human rights and liberties. And without it, addressing international terrorism has more in common with politics and political deference than with international law.

As can be expected, this makes for a highly complex situation in Europe. Human rights and liberties entrenched in the constitutional and legal tradition of the West - won in a long historical process in opposition to a strong state - have been an incontestable and inviolable canon of the political system. And it is the system which, in turn, underpins provisions in international law. Rights and liberties have become common in democratic states ruled by law, whereas threats to security have never been considered with due attention. In Europe, the Hobbesian Leviathan, symbolizing a strong state, was constrained by the constitution and resigned to the primacy of law and freedom.

Western states, in the understanding of Giovanni Sartori, have become consolidated democracies, in other words they are no longer in danger of reverting to authoritarian rule. In fact, Western states have gone even further. As advocates of the expansion of democracy, following the perspectives of Samuel Huntington and Francis Fukuyama, they believe that it is necessary and justified to overthrow despots in the name of freedom in other parts of the world. But not enough thought is given to the strategic or even tactical consequences of such moves. Warnings that the endemic anarchy, practically unavoidable, could be worse than the regimes of secular despots were largely ignored. Thus, one cannot but agree with the view held by the British theoretician of liberalism, John Gray, claiming that states should be free to choose their course of development and, as long as they do not represent a threat to others, even undemocratic regimes should be tolerated. ${ }^{4}$

3 T. Aleksandrowicz, Terroryzm międzynarodowy, Oficyna Wydawnicza Łośgraf, Warsaw 2008, pp. 89-90.

4 J. Gray, Heresies: Against Progress and Other Illusions, Granta Books, London 2004, p. 91. 


\section{Liberties and Security in the Catalogue of Constitutional Rights}

The new type of threats that emerged in the wake of 2001 represented a serious challenge to the democratic states of Northern America and Europe. In this new situation, states not only wanted but also had to strengthen their power and the effectiveness of counter-terrorism measures. The tenet which says "rights and liberties as much as possible while security as little as necessary" as a political directive in the fight against terrorism has become untenable. Terrorist threats necessitate more state power, among other things, in order to make state policies effective. But expanding state power does not conform to the liberal tradition upheld by democratic rule-of-law states. This creates a tension - a conflict between measures aimed at increasing safety and the ingrained tradition of the sanctity of rights and liberties. Thus, the question arises: what should be done (and in what way) in order to guarantee security to our citizens without a recourse to limiting their rights and liberties? In these circumstances, can a balance be maintained between liberty and security? Do we require liberty at all cost? On the whole, the question of how to maintain an appropriate proportion between freedom and security has been a primordial one, raised by political philosophy, by governments and the governed as well.

After 2001, these questions have found their way into mainstream political thought. In the legal, constitutional and political discourse the concept of security collided with the issue of individual, group, social and national freedom. Freedom has always been firmly embedded in the constitutional landscape of democratic states under the rule-of-law; the same cannot be said about security, although in modern constitutionalism, security is frequently treated as the constitutional right of an individual.

The connection between liberty and security was noted by Wilhelm von Humboldt, who maintained that security was the precondition of liberty. ${ }^{5} \mathrm{John}$ Stewart Mill, in turn, claimed in his philosophical work On Liberty that the power of the rulers, if uncontrolled, can give rise to tyranny and for this reason he placed a higher premium on freedom. ${ }^{6}$ Benjamin Franklin is credited with saying "Those who would give up essential Liberty, to purchase a little temporary Safety, deserve neither." This statement, much as a host of other views voiced by many political

5 H. von Humboldt, Ideen zu einem Versuch, die Grenze der Wirksamkeit des Staates zu bestimmen, in, Menschenbildung und Staatsverfassung. Texte zur Rechtphilosophie, Freiburg 1994, p. 94.

6 J. M. Mill, On Liberty, Kaplan Publishing, New York 2009. 
thinkers, illustrates the complex nature of the relationship between freedom and security. But does this interdependence necessarily point to a hierarchy between the two? It transpires that this relationship is a highly complex one. Firstly, at a certain stage of state development both security and freedom have become the state's basic objectives. Secondly, the two notions are essentially diverse and often opposing. Thirdly, security is associated with the lack of threats, while freedom with the generation of threats. And fourthly, the fulfillment of state tasks in terms of freedom is of an individualized nature, whereas tasks in terms of security - are implemented collectively.

The opposition between the aims of fulfilling freedom and that of security within a state can produce a paradoxical situation. A state which aims to implement full security, needs to be omnipotent in all matters, thereby undermining freedom and, in this sense, indubitably, arousing the opposition between freedom and security.

From today's perspective, we are dealing with freedom when coercion is absent, and with security - when our life, body, privacy and freedom are not endangered. To guarantee security in freedom today means decidedly more than to effectively guarantee public order. What is more, fulfilling these tasks in the area of security should take place in such a manner so as not to curb the rights and freedom of the people. Security without freedom leads to authoritarian or totalitarian rule. Freedom, however, requires a certain dose of security: in order to live in freedom, we need security. Currently, the relationship between freedom and security is yet more complex than before, making Benjamin Franklin's opinion untenable, as the two values are difficult to hierarchize. With this in mind, let us turn to Karl R. Popper who believed that we can achieve security through freedom: "We must plan for freedom, and not only for security, if for no other reason than that only freedom can make security more secure."

The complex relationship between freedom and security is evident when the two values are implemented in governance. However, it is worth noting that in the process of their implementation the state behaves differently. In terms of security, state tasks would amount to protecting legal goods in the area of private relations and on preventing the interference of other agents into the citizens' matters. This implies an active role of the state and its institutions as expressed in its legislative, judiciary and administrative activity.

7 Ch. Gusy, Gewährleistung von Freiheit und Sicherheit im Lichte unterschiedlicher Staatsund Verfassungsverständnisse, in: Veröffentlichungen der Vereinigung der deutschen Staatsrechtslehrer, Berlin 2004, p. 155.

8 K. R. Popper, The Open Society and Its, Princeton University Press, Princeton 1994. 
From the perspective of freedom understood mainly in negative terms, the state is not required to be particularly active - it should just refrain from reacting, or act in such a way so as not to interfere into or restrict the activity of members of the public. But even if the law allows for imposing limits on our freedom, these limits inherent in the provisions in place should not constrain the very essence of freedom. In the latest interpretations, the so-called doctrine of positive obligations requires state organs to act while at the same time maintaining a balance between individual and collective interests in terms of exercising their right to freedom. States are obliged to facilitate the effective use of the rights and freedoms that the individual is entitled to by creating an appropriate legal system.

The history of the development of modern states has noted periods of exceptional tension between the guaranteeing of security and freedom. The expectation that the state would achieve both goals was met with varying degrees of success. In practice, more often than not, states would subordinate everything to security. In other words, we are dealing with the primacy of security over other areas of public life. The deviational nature of this superiority becomes evident in authoritarian and totalitarian regimes.

The problem of a relationship between the two values reemerged in the aftermath of the 9/11 attacks but this time it was approached differently. Exacerbating the complexity of this relationship is the fact that human rights and liberties are addressed by almost all state constitutions whereas security is sometimes overlooked. It is often difficult to speak of the right to security, and when it does take place it needs to be drawn from a broader interpretation of constitutional regulations.

Historically speaking, security as a right appeared for the first time in documents defining the natural rights of a human being arising from the human being's innate dignity. The need to protect this right was the motivation behind the authors of the American Declaration of Independence and the French Declaration of the Rights of Man and of the Citizen. Article 2 of the French Declaration reads: "The goal of any political association is the conservation of the natural and imprescriptible rights of man. These rights are liberty, property, safety and resistance against oppression." Subsequently, security as a right and a certain value was included in the French Constitution of 1793. Ideas embedded in the American Constitution and French Declaration have profoundly influenced European constitutionalism. In European liberal constitutional thought of the nineteenth century, the issue of security, next to freedom, was vitally important. It has to be underlined, however, that security at that time was interpreted as legal security which was to guarantee protection against the abuse of power and individual freedom. An outstanding Polish researcher, Brunon Hołyst, frames the matter 
unequivocally, when he states that security is a basic human right, but at the same time adds that it can be fulfilled only as long as there is social and political understanding of the ethical and moral responsibility of both the state and society. ${ }^{9}$

Currently, in many European states constitutional or legal rules refer to security as an obligation of state authorities and, at the same time, as individual or people's rights. We must note, however, that this is not rendered expressis verbis in all basic laws. Often the right to individual security must be derived from a wider interpretation of constitutional provisions.

In the Polish 1997 Constitution, we find the concept of security in several articles. Article 5, for instance, speaks of the security of the citizens, which is seen as one of the state's basic tasks; and in Articles 26 and 126 - of the security of the state - as the general social weal, for the protection of which limits on the rights and liberties of individuals are allowed.

But as Dariusz Dudek rightly notes, "the security of a state has only prima facie higher value over the value of a human being's individual existence; this does not imply, that in each and every case and in all conditions it deserves absolute protection as a matter of utmost importance. On the contrary, the matter should be weighed carefully and responsibly." ${ }^{10}$ Article 135 , in turn, refers to the National Security Council, an advisory body to the President, competent in matters regarding the state's internal and external security. It is worth noting also, that the provisions of the Polish Constitution mention ecological security. In line with Article 74 Polish public authorities are required to pursue policies which ensure ecological security. As an aside, let us note, that the constitutionalization of security in Poland has a long tradition: the Government Act of 3 May 1791, Chapter 2, reads as follows: "Above all, we desire to preserve and do preserve sacred and intact the rights to personal security, to personal liberty, and to property, landed and movable, even as they have been the tide of all from time immemorial..."

The Constitution in force in Spain, in line with Articles 9(3) and 17(1) guarantees the right to security as well as legal security to its citizens. It is also worth pointing out that the preamble of the Spanish Constitution sees security as the basic premise, value and objective guiding the Spanish sovereign in establishing the political system. In the constitutions of Austria, Bulgaria, and the Netherlands, security is addressed as a task and duty of public authorities. The Dutch Constitution of 28 March

9 B. Hołyst, Bezpieczeństwo. Ogólne problemy badawcze, Wydawnictwo PWN, Warsaw 2014, p. 12.

10 D. Dudek, Bezpieczeństwo Rzeczypospolitej jako wartość konstytucyjna, in: Bezpieczeństwo Polski. Historia i wspótczesność L. Antonowicz, T. Guz, M. R. Pałubska (eds.), Wydawnictwo KUL, Lublin 2010, p. 183. 
1814, Article 20(1) states that the security of the existence of its population is in the care of the authorities. In the Federal Constitutional Law of the Republic of Austria of 1 January 1930, one can read that the laws and implementation in terms of security and public order lie in the competences of the Federation. The Constitution of the Republic of Bulgaria of 12 July 1991 states that the security of the individual is the supreme political principle (Preamble), and national security is the goal of its foreign policy. Security as a right was encapsulated in the Constitution of Finland on 11 June 1999. Article 19 says that the citizens have the right to social security, and Article 7, that everybody has a right to life, personal freedom, inviolability and security. The Portuguese Constitution, likewise, formulates the right to freedom and security in Article 27(1). Similarly, in the Constitution of the Republic of Cyprus of 16 August 1960 (Art. 11(1)), in the Constitution of Romania of 21 November 1991 (Art. 23(1)), and in the Constitution of the Republic of Slovenia of 23 December 1991 (Art. 34). In the Constitution of Malta of 21 September 1964 (Art. 32(a)), it is specified that everybody has a right to freedom and personal security. The wellknown German constitutionalist, Josef Isensee is of the opinion that the German basic law of 1949 frames security as a basic right - Grundrecht auf Sicherheit. ${ }^{11}$ This is not an interpretation that is shared across the board as it is not stated explicitly in the Basic Law. Let us mention, however, that in the original version of the Basic Law presented by the Parliamentary Council, in Article 3, the term "security" was used in connection with a discussion on safeguarding basic rights.

\section{Counter-Terrorism Policies: The Clash Between Freedom and Security}

Rights and freedoms are constructed in such a fashion so as to protect citizens from the interference of state organs. Nonetheless, counter-terrorism measures undertaken by the state, especially the indirect ones, consist in laying a legal groundwork for enabling this very interference. Accordingly, freedom in the negative sense (freedom from something), the protection from state intervention into individuals' private sphere, as well as freedom in the positive sense (freedom to), understood as the possibility to act freely (often called participatory freedom) are both undermined. In the face of a terrorist threat, the state is obliged to act effectively not only indirectly but also directly. Thus, a specific dependence occurs between freedom and security. Under the rule of law, this connection between rights and liberties on the one hand,

11 J. Isensee, Das Grundrecht auf Sicherheit. Zu den Schutzpflichten des freiheitlichen Verfassungsstaaten, De Gruyter Verlag, Berlin 1983. 
and security on the other, makes the undertaking of measures with a view to preventing and fighting terrorism by state organs and institutions extremely complex.

The nature of the measures undertaken by governments boils down to the change of regulations defining the competencies of the secret service and police with regard to collecting and storing personal information. This calls for amending the law in accordance with the constitution. However, we must remember that in a democracy this is a particularly sensitive issue, as it places a state's internal security and the question of freedom on the top of the political agenda.

For the most part, the support and acceptance of the public for anti-terrorism measures depends on the time and degree of the terrorist threat. Fear and a sense of peril immediately after a terrorist attack generate social support for more intense anti-terrorism measures and procedures. As more time elapses after the attack, the public is more reluctant to support these moves. Those voters who are unequivocally convinced about the primacy of freedom over security will continue to believe that the measures and procedures of control and surveillance over society carry important risks. They tend to be in favor of maintaining rights and liberties and against subjecting them to limitations.

The public is ready to support regulations defining special measures with regard to the protection of critical infrastructure against terrorist attack, but to a lesser degree approves of such regulations which directly deal with people: for instance, baggage checks, wiretapping or being profiled in the public realm. The measures and procedures employed in countering and fighting terrorism are nothing but the scanning of the public by means of various criteria. The knowledge and information thus acquired is vast and dangerous. On the one hand, it enables the police and secret service to interfere in politics. On the other hand, the world of politics is tempted and often yields to the desire of acquiring and taking advantage of the stockpile of information in their struggle for power or in their attempt at maintaining their grip on it.

Still, another element must be taken into account: namely, the fact that terrorism and the fight against terrorism are two mutually exclusive categories. Etymologically, the term terrorism is derived from the Greek, treo - to tremble, to be afraid, or the Latin terror and terreo - fear, trepidation and instilling fear. Contemporary media amplify concerns about the terrorist threat causing even greater fear and shock. Terrorism defines the threatened majority and profiles the individual or minority as a threat. If anti-terrorism measures and procedures undertaken are constructed on the principle of exclusion following the criteria of ethnic, religious, racial or cultural profiling, this may lead to the discrimination of certain communities, and in consequence to the radicalization thereof. Even 
though state organs need authorization for taking up effective counter-terrorism measures, the definition of these measures and their application requires the utmost equanimity as this effectiveness may breed new unwanted risks.

Governments apply a broad and general concept of terrorism, as the term is not precisely defined. In these circumstances counter-terrorism measures at the disposal of governments can have a wide range of usages. For instance, they can be employed to prosecute political adversaries or they criminalize activities designed to implement the right to self-determination. An example of the instrumental use of these measures was the conduct of Prime Minister Jose Maria Aznar's government in Spain when following the 2004 terrorist attack in Madrid, right before the general election, it attempted to put the blame on ETA, despite the fact that the intelligence service had information pointing to members of the Al Qaeda as the perpetrators of the act.

All these elements together affect the proper relationship between freedom and security. For the most part, it is because changes to terrorism laws have yet to catch the public's attention. Although the amendments introduced to existing laws are of a temporary nature the expiry date is being put off by governments, without being debated publicly. When these legal changes finally spark off a public debate, it turns out that understanding complex legal issues, which refer to intricate technical matters, is very difficult for somebody not well versed in these matters. Besides, there is not enough transparency surrounding the changes to laws with regard to countering terrorism. More often than not, the debate resembles a discourse between the government coalition and opposition, or a professional discourse between academics and experts. The quality of the discourse among professionals, including representatives of science, administration or the secret services is often not of the highest quality. As for the political debate, it frequently provokes violent conflicts between the participants but they concern general issues rather than the complex legal details, which are necessary for the police and other special forces to undertake anti-terrorism actions.

In the legal proposals put forward by governments in the area of fighting terrorism diverse solutions can be found. They usually come in the form of complex packages of amendments concerning several laws, which should be analyzed together. In Germany the updating of the law in this regard included seventeen acts, several regulations, together encompassing more than a hundred provisions. ${ }^{12}$ In Poland, likewise, a dozen or so acts were amended. Polish politicians have for

12 B-S. Kreitz, Innere Sicherheit - Das ideale Wahlkampfthema?, Universitätsdrucke Göttingen, Göttingen 2012, p. 70. 
many years been announcing plans for the enactment of an anti-terrorism law and another one concerning the control over police operations, but so far no specific bills have been put forward.

Judging by the practice in many countries so far, amending terrorism law legislation usually goes too far and touches on issues concerning the political system. This was the case with the first and second anti-terrorism packages in Germany, where critics concluded that, the changes amounted to a rejection of the rule of law and were moving the country in the direction of a preventative state (Präventionsstaat). ${ }^{13}$ In Poland, a similar amendment drew a critical judgment from the Constitutional Tribunal, while the most recent attempt at adjusting the same law attracted a wave of criticism from the opposition.

It transpires that only rule-of-law democracies with their constitutional courts are in a position to assess whether the means and procedures suggested by governments and approved by parliaments fall within the constitutional norms which regulate human rights and liberties. Both the German and Polish constitutional courts deemed many regulations to be at odds with these norms and recommended appropriate amendments to some of them. In the same way, the European Court of Human Rights found that the Terrorism Act 2000 in the UK allowed for measures that were incompatible with human rights and infringed on the right to privacy. ${ }^{14}$ Generally speaking, however, international institutions find it difficult to adjudicate in these matters on account of the already mentioned lack of a precise definition of terrorism. In the same way, the potential for reacting to acts of terrorism on the part of international institutions is much curtailed, as is their ability to pass judgments on counter-terrorism measures that states employ.

Thus, as can be seen, counter-terrorism measures undertaken by governments touch on the specific relationship between freedom and security, which in a way resembles a self-regulating system. A correlation between freedom and security would amount to the following: offering more entitlements to one side is accompanied by more or less entitlements on the other side.

\section{Conclusion}

To conclude, one may accept that freedom and security in the context of combating terrorism do not necessarily have to conflict with each other. Freedom and

13 S. Huster, R. Karsten (eds.), Vom Rechtsstaat zum Praventionsstaat, Suhrkamp Verlag, Frankfurt am Main 2008.

14 Gillan and Quinton v. United Kingdom, The European Court of Human Rights, application no 4158/05, 12 January 2010. 
security in a democracy are among its most treasured values and important tasks, and as such they should mutually complement each other.

In order to maintain an appropriate relationship between rights and freedom versus security in the context of fighting terrorism the appropriate conditions should be put in place. Firstly, the quest for adopting a definition of terrorism in international law should be encouraged. Secondly, drafts of internal law amendments addressing the fight against terrorism should be more transparent. Thirdly, constitutional courts in rule of law democracies should adjudicate whether these amendments comply with the constitution. Fourthly, civil supervision over anti-terrorist measures employed by the police and intelligence service should be ensured. The best guarantee of preserving the correlation between freedom and security is the operation of accountability in political systems. ${ }^{15}$

All things considered, however, it must be underlined that these measures are only designed to counteract and fight terrorism but do not in any way stamp out the causes of terrorist acts. The eradication of terrorism is a much broader and complex matter. It would require instituting global policies and the cooperation between states to remove the material and subjective conditions contributing to the emergence of terrorist activity. John Gray rightly notes that in this respect a coalition of like-minded states must necessarily include Islamic states. ${ }^{16}$ We must prevent the further drifting apart of the Islamic and Western worlds, as well as the continuing radicalization of the relationship between the two on the political, economic and cultural arena. Only a broad-based alliance between the two worlds can provide the underpinnings of a new international order, whereby different cultures and political systems would coexist free from terrorist threat.

\section{References}

T. Aleksandrowicz, Terroryzm międzynarodowy, Oficyna Wydawnicza Łośgraf, Warsaw 2008.

Gillan and Quinton v. United Kingdom, The European Court of Human Rights, application no 4158/05, 12 January 2010.

D. Dudek, Bezpieczeństwo Rzeczypospolitej jako wartość konstytucyjna, in: Bezpieczeństwo Polski. Historia i współczesność L. Antonowicz, T. Guz, M. R. Pałubska (eds.), Wydawnictwo KUL, Lublin 2010.

15 A. Sroka, Rozliczalność w badaniach jakości demokracji (na przykładzie Polski i Hiszpanii), Wydawnictwo Elipsa, Warszawa 2014.

16 J. Gray, Heresies: Against Progress and Other Illusions, Granta Books, London 2004, p. 90. 
J. Gray, Heresies: Against Progress and Other Illusions, Granta Books, London 2004. Ch. Gusy, Gewährleistung von Freiheit und Sicherheit im Lichte unterschiedlicher Staats- und Verfassungsverständnisse, in: Veroffentlichungen der Vereinigung der deutschen Staatsrechtslehrer, Berlin 2004.

H. von Humboldt, Ideen zu einem Versuch, die Grenze der Wirksamkeit des Staates zu bestimmen, in, Menschenbildung und Staatsverfassung. Texte zur Rechtphilosophie, Freiburg 1994.

B. Hołyst, Bezpieczeństwo. Ogólne problemy badawcze, Wydawnictwo PWN, Warsaw 2014.

S. Huster, R. Karsten (eds.), Vom Rechtsstaat zum Praventionsstaat, Suhrkamp Verlag, Frankfurt am Main 2008.

J. Isensee, Das Grundrecht auf Sicherheit. Zu den Schutzpflichten des freiheitliche Verfassungsstaaten, De Gruyter Verlag, Berlin 1983.

G. Kepel, La revanche de Dieu. Chretiens, juifs et muslumans la reconquwete du Monde, Editions du Seuil, Paris 2003.

B-S. Kreitz, Innere Sicherheit - Das ideale Wahlkampfthema?, Universitätsdrucke Göttingen, Göttingen 2012.

Memorandum from US President G. Bush, Human Treatment if Taliban and al Qaeda Detainees, available at http//www.fidh.org/IMG/pdf/memo11, accessed 21 December 2015.

J. M. Mill, On Liberty, Kaplan Publishing, New York 2009.

K. R. Popper, The Open Society and Its, Princeton University Press, Princeton 1994.

A. Sroka, Rozliczalność w badaniach jakości demokracji (na przykładzie Polskii Hiszpanii), Wydawnictwo Elipsa, Warszawa 2014. 



\section{Fanny Castro-Rial Garrone}

\section{An Updated Approach to the Study of Terrorism}

\section{Introduction: The Progressive Reality of the Jihadist Terrorist Threat}

An updated approach to the study of jihadist terrorist action requires an extensive terminological specification, which compels us to frame jihadist action within the phenomenon of terrorism, ${ }^{1}$ while singling it out due to its specific connotations. Thus, it can be differentiated either in terms of its ideological approach or by determining its action strategies, since one of its most defining characteristics is metamorphosis, understood as the capacity of different forms, in which the threat can act, to evolve and transform, as observed in the emergence of new figures, such as lone wolfs, foreign fighters, and returnees.

We must therefore abandon the commonly used terms "Islamic terrorism" or "jihadist terrorism", ${ }^{2}$ since we should avoid the mistake of stigmatizing a religious belief such as the true Islam, which does not necessarily entail any violent connotation. ${ }^{3}$

It is our belief that the repeated use of those terms can contribute to the argumentation of jihadist terrorists, thereby turning the situation in their favor and creating a counterproductive side effect of reinforcing these groups' false premise of Western hostility toward Islam, which would support the intent of presenting themselves as victims of the Western world intolerant to their beliefs. On the contrary, the very essence of democratic values in a multicultural society supports and defends freedom of speech, a freedom which is used perversely with criminal intent, to safeguard their proselytism, which is incidentally free of true religious purpose, promoting a lawless indoctrination leading to terrorist acts, perpetrated under the shelter of the existing liberties of a democratic society in an attempt against the safety of its citizens. ${ }^{4}$

1 L. de la Corte Ibañez, H. Hristowa Gergova, El terrorismo como objeto de estudio: algunas notas introductoria, "Studia" no. 14, 2011, pp. 29-43.

2 J. Jordán, P. del Pozo (eds.) Terrorismo sin fronteras. Actores escenarios y respuestas en un mundo global, Aranzadi, Pamplona 2010.

3 J. R. Thackray, Dictionary of Terrorism, Routledge, London 2004.

4 P. Wilkinson, Terrorism versus democracy. The liberal State response, Frank Cass, London 2005. 
"Terrorists are attacking our way of life, in an attempt to spread fear and sow divisions in our societies. There are no quick and easy ways to resolve these issues. As the holder of the EU Council Presidency, it is incumbent on the Netherlands to help the EU find common solutions in these turbulent times. Unity and resolve are needed at all levels. The effective combination of European and national measures will form an important basis for those solutions."

There is a need to act within the framework of a free society committed to democracy, but in the way which avoids easy judgments or a convenient do-gooder attitude.

The origins of the Daesh movement can be traced back to the conflicts in Afghanistan and Iraq. What is of special importance, however, is that it has effectively transformed the reality of the Middle East and international politics in the summer of 2004 through the abandonment of traditional war techniques, the return to guerrilla war, and the proliferation of terrorist attacks, as well as by extending its territorial scope of action. This extended scope was evidenced by the terrible terrorist attacks in Paris, which have shaken Western democratic conscience, or by the fatal attack against the Spanish embassy in Kabul, causing the death of two Spanish policemen and an Afghan security agent, as well as by the more recent terrorist attacks perpetrated in Istanbul, Malaysia, Burkina Fasso, and Brussels.

These acts are not just contrary to democratic principles; they also articulate terrorist politics and actions. The appearance of the international jihadist movement initially shared its goals with the terrorist movement of Al Qaeda. However, it has to be taken into account that there is no single doctrine of hierarchical unity in these terrorist groups, since the emergence of ideological conflicts between their members can be noticed, dividing them with regard to both their objectives and doctrines. The term "jihadist terrorism" can be no longer applied to extremist orthodoxies, since this usage may lead to an erroneous perception which depolitizes the conflict.

Currently, jihadist terrorism has equipped itself with an ideology which perfectly encapsulates the concept of "totalitarian ideology." It is clearly antidemocratic, because it systematically encourages attempts against the lives of those

5 J. Jordán, El terrorismo yijhadista en España: evolución después del 11M, 2009, available at http://www.realinstitutoelcano.org/wps/portal/rielcano/contenido?WCM_GLOBAL_CONTEXT=/elcano/elcano_es/programas/terrorismo+global/publicaciones/ publ-amenaza+espana/dt7-2009, accessed 9 November 2015. 
opposing it. ${ }^{6}$ The goal of the terrorists is broadly political, as they seek to destabilize the societies in which they act. The political action of jihadist terrorism aims to subvert the established rule of law in order to implement Islamic law. It thereby becomes the foremost exponent of terrorist action focused on a "far enemy."7 Their religion is not as important as their submission to the above mentioned ideology. We should therefore underline how, in the execution of their terrorist policies, the highest number of victims are fellow Muslims. It is a mistake to ground jihadist terrorism exclusively in a fanatical interpretation of Islam. ${ }^{8}$

This has been evidenced by a recent operation by the EU judicial cooperation, which in November 2015 enabled 15 simultaneous arrests in Italy, Norway, the United Kingdom and Finland, dismantling a terrorist cell composed mainly of Kurds. Once their intentions were clarified, one could see that they not only strived to carry out terrorist acts, kidnapping diplomats on the Norwegian soil, but also aimed to overthrow the Iraqi Kurdistan government and substitute it for a caliphate ruled by the Islamic law, also known as sharia.

It is necessary to approach this phenomenon, taking into account its aim of re-Islamizing society through the creation of real political structures (as it was made clear in their statements after proclaiming the Caliphate, the Islamic State, the claim on Al Andalus, particularly relevant to Spain due to the existence of the enclaves of Ceuta and Melilla). ${ }^{9}$

It also seems advisable to separate the phenomenon of radical individual perception, ${ }^{10}$ due to the proliferation of movements nurturing radicalization, as a result of the social crisis, which acts as a breeding ground, without a doubt

6 I. Bremmer, How terror could kill the European project, "Time" vol. 186 no. 22-237, 2015, p. 11.

7 R. Bjarnason, A Report from the democracy incubator hackathon, World Forum for Democracy 2015, 21.12.2015, available at https://www.opendemocracy.net/wfd/robert-bjarnason/world-forum-for democracy-2015-report-from-democracy-incubatorhackathon, accessed 12 January 2016.

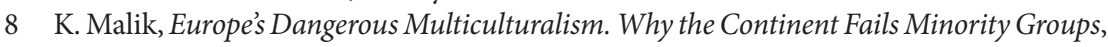
2015, available at https://www.foreignaffairs.com/articles/western-europe/2015-12-08/ europes-dangerous, accessed 18 December 2015.

9 B. M. Juergensmeyer, Terrorismo religioso. El auge global de la violencia religiosa, Siglo XXI, Madrid 2001.

10 M. Crenshaw, The psychology of political terrorism, in: Policital Psychology. Key readings J. T. Jost, J. Sidanius (eds.), Pshicology Press, New York, 2004. 
enabling the strengthening of violent stances. ${ }^{11}$ Radicalization is not a sufficient motivation for terrorist acts, although it can elicit terrorist actions. ${ }^{12}$

Simultaneously, the emergence of a so-called "new terrorism," exercised by those who are ready to assume a fanatical interpretation of Islam, coexists with other radical religious orthodoxies. It is indeed true that jihadist terrorist action thrives in the shadow of an idealization of the Caliphate in opposition to the loss of values in Western society, which, in turn, assists the recruitment of young European citizens and, particularly, the adherence of women; for, as the research of García Calvo shows, they are targeted by propaganda ${ }^{13}$ (her study provides evidence of how $75 \%$ of all individuals arrested on charges of jihadist terrorism in Spain are female).

The study of recent acts of jihadist terrorism allows us to simultaneously verify that we are facing a phenomenon which is not static, but undergoes constant evolution. That is why it is reasonable to consider any research as "unfinished."

Our aim, then, is to articulate the notion of protecting the security of our society against the proven vulnerability of the State, considering this phenomenon from an all-encompassing perspective, which cannot ignore social movements, and stressing the phenomenon of radicalization and new actions of foreign fighters, since this phenomenon "concerns violent radicalization and follows recent terrorist attacks by foreign fighters in Europe" and "appropriate and concrete responses to the phenomenon of radicalization and the solutions to deal with this common challenge" are searched. It was expressed in these terms in the Conclusions of the Council approved on 16 June 2015, which pay particular attention to the radicalization in prisons and a preventive approach to antiterrorist action. ${ }^{14}$

The current approach adopted by the Commission, which prioritizes "combatting radicalization, marginalization of youth," has been combined with the European Fundamental Rights Agency to promote respect, non-discrimination, fundamental rights, freedoms and solidarity. The Commission is currently

11 B. M. Juergensmeyer, Terrorismo religioso. El auge global de la violencia religiosa, Siglo XXI, Madrid 2001.

12 F. Foley, Políticas antiterroristas en Europa, available at http://fundacion.unirioja.es/ formacion_cursos/view/312/sub:2354, accessed 7 December 2015.

13 F. Reinares, C. García Calvo, Terrorist network and organisations aspects of the current jihadist mobilisation in Spain, available at www.realinstitutoelcano.org/wps/portal/ Web/rielcanoes/contenido?WCMGlobal-context, accessed 9 January 2016.

14 Council of the European Union, Response to foreign terrorist fighters and recent terrorist attacks in Europe available at http://www.consilium.europa.eu/en/meetings/ iha/2015/06/15-16/, 2015, accessed 21 January 2016. 
implementing all-encompassing initiatives (education, culture, sports, employment, welfare, security) and a new policy on how to use education to prevent radicalization. ${ }^{15}$

While Al Qaeda's attacks against American interests started in the twentieth century against the diplomatic sites in Kabul and Tanzania, or against the US Destroyer Cole in Yemen, those attacks have been repeated in the current century in New York, London and many other cities. The terrible actions of Daesh and the Paris terrorist attacks represented a turning point in the awareness, inspiring a holistic approach to the issue. ${ }^{16}$

The evolutionary reality of the jihadist terrorist threat is embodied in the increase of their indoctrination policies. The responsive action of our security forces can be seen in the Spanish case. These terrorists are Muslims, and many among them are converts. We can point to the recent investigations conducted by Spanish Police in the Spanish city of Ceuta (December 2015) and the Spanish enclaves of Ceuta and Melilla, ${ }^{17}$ but it was in Barcelona where the arrests took place.

This recent reality of the "foreign fighters", whose actions as returnees constitute a serious security risk in Western countries, has also contributed to increase the perception of it as one of the most serious threats to global society. ${ }^{18}$

According to General Joseph L. Votel, at the "Counterterrorism: Unconventional Approaches to an Unconventional Threat" conference ${ }^{19}$, the lesson to be learned from $9 / 11$ was the lack of imagination to envision that a group of terrorists could learn to operate large commercial passenger airliners and then fly them into tall buildings where thousands worked. In his view, it was also this lack of imagination, that has led us to collectively dismiss intelligence reports pointing in that direction.

15 M. Sageman, Understanding terrorism networks, University of Pennsylvania Press, Philadelphia, 2004.

16 United Nations Strategies UN 2006 Global Counter-Terrorism Strategy, 2015, available at http://www.Un.org/terrorism/strategy-counter-terrorism.shtml, accessed 9 November 2015.

17 J. Jordan, Evolución organizativa de la militancia jihadista en España, 2014, available at http://www.realinstitutoelcano.org/wps/portal/web/rielcano_es/contenido?WCM_ GLOBAL_CONTEXT=/elcano/elcano_es/zonas_es/ari12-2014-jordan-evolucionorganizativa-militancia-yihadista-espana, accesed 9 November 2015.

18 European Council, Conclusions of European Council meeting 15 October 2015, available at http://www.consilium.europa.eu/en/press/press-releases/2015/10/16-euco-conclusions/, accessed 20 January 2016.

19 F. Reinares, C. García Calvo, Terrorist network ...op.cit. 


\section{The Surge of Home-Grown Terrorism in Spain}

While we are fully aware that the Spanish case is still far from the situation in other European nations, it is reasonable to assume that our country lacks the jihadist mobilization issues, which are at work in countries such as Germany, France, the United Kingdom, and Denmark. It is worthy to discuss the opinion of experts Fernando Reinares and Carola García Calvo, researchers at the Elcano Royal Institute, a think tank for international and strategic studies, who have had the opportunity to present the paper Terrorists, network and organisations: aspects of the current jihadist mobilisation in Spain at the III Forum organized by the Royal Institute on Terrorism and which has acquired particular significance after being exposed to unfortunate coincidence due to its proximity to the Paris terrorist attacks. ${ }^{20}$

The authors defend the existence of a home-grown and endogenous jihadism in Spain. This vision is founded on ascertaining that $45 \%$ of arrested individuals in Spain for Islamic radicalization motives are Spanish nationals, and 40\% were born in Spain.

The study is of indubitable value, as it allows us to delve deeper into the profile of the radicals established in our country. We now have the opportunity to verify their course of action, which does not correspond to the usual profile of the lone wolf, since it includes collaborating with other, newly or previously established groups. Their ties to the organization and jihadist terrorist networks are also clarified: they are related mostly to the Islamic State, followed by the Al Nusra Front (27.6\%), MUYAO (12.2\%), Harakat Sham al Islam (11.2\%) or AQMI (7.1\%).

Once this has been ascertained, the orientation of the functions assumed by these terrorists is clarified as mainly focused on tasks of proselytism $65.3 \%$, fundraising $60 \%$, carrying out technically operative actions $42.1 \%$, and training $29.5 \%$.

Based on the work of Fernando Reinares and Carola García Calvo, we can sketch the basic features of the Spanish jihadist: a man of around 28 years of age, born in one of the two big cities where jihadists are usually natives: Ceuta and Melilla (almost 76\%). Their actions are reported mostly in Catalonia, since it is there where the profile is located and where most of the arrests take place. In

20 Real Instituto Elcano, III Foro Elcano sobre Terrorismo Global, 2015, available at http:// www.realinstitutoelcano.org/wps/portal/web/rielcano_es/actividad?WCM_GLOBAL_ CONTEXT=/elcano/elcano_es/calendario/actividades/iii-foro-elcano-terrorismoglobal, accessed 10 January 2016. 
terms of nationality, the researches concluded that the number of jihadists born in Spain is 7.3\% lower than that of the residents in Spain (47\%).

This research allows us to pinpoint their provenance from the region of Tangiers-Tetuán-Alhucemas (every four in ten arrested individuals came from there), as well as the primary provenance of $75.8 \%$ of all arrested individuals, who were born in Ceuta and Melilla, followed by Morocco (37.4\%), Tunisia (5.2\%), Algiers (3.5\%) and France (2.5\%).

The ten arrests carried out between 2011 and 2015 have taken place in Tangiers, Tetuán, Alhucemas (four in ten arrests), and within the peninsula, 5\% in Barcelona and $2.4 \%$ in the following A Coruña, Almonte Cádiz, Ciudad Real, Granada, Sant Boi de Llobregat, Sant Feliú de Guixols, and Tarragona.

It is necessary to focalize policies in these areas, implementing "strategies in the environment where they grow, with a significant work in the Internet and social media, are important ways of radicalization."

\section{Awareness within EU Institutions and International Response}

The fact that six of the most significant terrorist attacks of 2015 were perpetrated on the European soil evidences the challenge faced by the security forces of the Member States, as well as the loss of individual response capacity to confront them. The evolution and current increase of the threat has raised awareness within the EU's institutions. The EEAS, EU Agencies and Interpol finalized last May a first set of common risks indicators.

Such is the conclusion to be extracted from the statement: "les attentats terroristes perpétrés... n’ont fait que renforcer notre détermination à poursuivre notre lutte sans concession contre le terrorisme."21 This is also apparent in the European Council Declaration of 12/2/2015, as well as in the Conclusion of the Council from 20/11/15, and in the periodical undertaking by the European Council of the defense of its values and the efficacy of convened action. For their part, Juncker's Commission has set European security as one of its priorities, including an "upgrading" process in the security program for 2015. In terms of priorities for immediate action, these are: ${ }^{22}$

21 European Commission, Commission Work Programme 2016, available at http:// ec.europa.eu/atwork/pdf/cwp_2016_annex_i_en.pdf, accessed 20 January $201 \overline{6}$

22 Council of the European Union, Draft Council Conclusions on the Renewed European Union Internal Security Strategy 2015-2020, 2015, available at http://www.consilium. europa.eu/en/meetings/jha/2015/06/15-16/, accessed 21 January 2016. 
1. Tackling terrorism and preventing radicalization.

2. Disrupting organized crimes.

3. Fighting cybercrime.

The European Council stressed on February 12 $2^{\text {th }}, 2015$ the urgency of adopting measures reinforcing the cooperation between national security services across the EU. Although the primary responsibility has to be assumed by the States, they are urged to improve the information exchange in order to deepen the combined operational analysis of the terrorist threat. "The present proposal is without prejudice to responsibilities incumbent on the Member State with regard the maintenance of law and order and the safeguarding of internal security in accordance with Article 72 TFEU."23

The ultimate objective in facing these new challenges is indubitably the defense of "universal values," preserving a plural society, non-discrimination, tolerance, justice, solidarity and equality, taking into account the threat of free circulation within the European territory, fostering the movement of terrorists using it as a mere transit to reach the conflict areas in Iraq, Syria, etc. ${ }^{24}$ The new approach assumes the insufficiency of the European action deployed and the current deficiencies as well as the need for a "full use" of the instruments already in place that are underused at the moment. There are means which should be better employed, in particular the Europol Counter Terrorism CT, Eurojust, PrUm, SIS II, Eurodac and Interpol. It would be also advisable to develop a better interaction by the EU Coordinator for the fight against terrorism with the Commission and the High Representative, considering the fact that they are also required to inform the European Council, which has repeatedly urged the Member States to improve the quantity and quality of information they share on terrorist suspects. ${ }^{25}$

At any rate, all measures to enhance security must implement the obligation of respect of fundamental rights. Any measure should be in accordance with principles of necessity, proportionality and legality, with appropriate safeguards to ensure accountability and judicial redress (Article 6). ${ }^{26}$

23 European Parliament, Preventing radicalisation in the EU, 2015, available at http://www.europarl.europa.eu/RegData/etudes/ATAG/2015/571342/EPRS ATA\%282015\%29571342_EN.pdf, accessed 15 December 2015.

24 European Commission, COM (2016) 230 final, Brussels, 20.4.2016.

25 Europol, EU Terrorism Situation and Trend Report, 2015, available at https://www. europol.europa.eu/content/european-union-terrorism-situation-and, accessed 14 January 2016.

26 Council of the European Union, Conclusions of the Council of the European Union and of the Member States meeting within the Council on enhancing the criminal justice 
The EU is a rule of Law Community. Any limitation is subject to the conditions described in Article 2 (1) of the Charter of Fundamental Rights, namely to the principle of proportionality that will be respected in limiting the scope of the offenses to what is necessary to allow for the effective prosecution of acts that pose a particular threat to security.

Among current priorities is a better use of information, whether through the exchange of information between national authorities responsible for the fight against terror, which in the Schengen cases would give way to a second generation of data related to foreign fighters, or through a systematization of the information exchange regarding terrorists also linked to organized crime, including citizens of third countries in "ECRIS".

A better interaction between Eurojust and Europol should be promoted. The implementation of the SIENA system (Information Exchange Network Application) and the "Europol System" were particularly helpful, as well as the so far unfinished "EIS" for Counter-terrorism. Strengthening the exchange of information within Eurojust by virtue of the Council Decision 2005/671/JHA) and Article 13 of the Eurojust Decision is of particular importance.

As such, "Member States will ensure that national authorities enter systematically data on suspected foreign terrorist fighters into the SIS II, in particular under Article 36. 3, carry our awareness raising and training on the use of the SIS and define a common approach to the use of the SIS II data relating foreign fighters." ${ }^{27}$

The operationalization of this common risk as the "New Border Package" conveys Frontex's support of awareness-raising training in the Member States. The European Border Guard and the Smart Borders initiative planned to implement a more effective control over the EU's borders by tracing the third-country nationals movements across the EU's external borders.

Particularly relevant is also the interaction regarding cybercrime. Since last March, the European Centre of Excellence, the EU Internet Referral Unit (EU IRU), has actively searched the Internet for terrorist materials, helping to reduce the rising volume of terrorist materials available and supporting competent authorities. Europol urged to coordinate and share the identification task (flagging)

response to radicalisation leading to terrorism and violent extremism, 2015, available at http://www.consilium.europa.eu/en/press/press-releases/2015/11/20-conclusions-radicalisation/, accessed 18 December 2015.

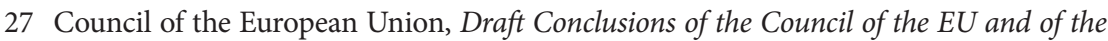
Member States meeting within the Council on Counter-Terrorism, 2015, available at http:// www.statewatch.org/news/2015/nov/eu-jha-20-nov-draft-conclusions-14298-15.pdf, accessed, 4 December 2015. 
of terrorist, violent or extremist online content with relevant partners. As its main objective, the EU centre (IRU) assesses the material and confirms whether it has breached the terms and conditions of the companies, in order to remove that material from websites and pass their URL's to the host companies. This "Check the web initiative" allows Europol reports on the evolution of the threat, helping national authorities and taking into account the potential of the technological evidence due to its new characterization compared to the classic one, its endurance over time, the machinability, volatility, and mass. Thus, the "e-evidence" of terrorist networks, in light of the Council Decision 2005/671/JHA, forces the State Parties to exchange information in investigations, prosecutions and convictions. They already use a reserved but transcendent report which makes it possible to approach to the case-law of State Parties in order to improve the good practices, as well as to develop a deeper insight into the phenomenon. The Paris attacks evidenced the need to improve the efforts at external borders, both perfecting the FTF register included in the SIS II and checking the SIS II and Interpol databases.

For this reason, the work at Eurojust tends to develop the legal frame of recruiters and facilitators, and must be coordinated with the control of foreign fighters through the "Europol Focal Point Travelers", enforcing the November 2015 conclusions, which demand: "Member States will make the maximum use of these capabilities to improve the overall level of information Exchange between $\mathrm{CT}$ authorities in the EU. Member States will ensure that the relevant national authorities significantly increase their contributions to Focal Point Traveler at Europol reflect the threat and connect to relevant Europol information exchange systems." 28

Regarding the action deployed by Europol and on its behalf, the Centre for the fight against terrorism has to support the action of Frontex through the cooperation between its main partners. Eurojust indeed possesses two valuable instruments: on the one hand, "Liason Prosecutor," and, on the other hand, the agreements with 37 non-Party States (MENA), reinforcing cooperation with those in North Africa, Near East, Western Balkans, and Turkey.

The idea of granting more efficacy to the European action - and consequently, the preventive nature of the EU's activities - demands as an essential tool the interconnection of the Europol countries, which, together with the Secure Information Exchange Network Application (SIENA), should devise and operate within a specific anti-terrorist area, enabling bi- and multilateral communication through cooperation agreements, including national authorities from third party

28 Council of the European Union, Draft Conclusions of the Council...op.cit. 
countries outside Europol. Since not all State Parties have used EIS, there is still a long way to go on the path toward a more effective control of foreign fighters.

\section{Toward a New Framework Directive on Terrorism}

The 2016 action program by the Commission includes reviewing the Framework Directive on terrorism from a teleological perspective.

The legal frame currently in effect is being reviewed, as captured in the current proposal for a "Directive on Terrorism." The regulation reform is ambitious, as it tries to replace the framework currently in effect, that is, the Framework Decision 2002/475/HA, whose contents are nowadays considered insufficient to create the intended response to the current European challenges, and do not reflect the global approach. For this reason, its contents need to be adapted both to the current reality and to the already established international parameters. ${ }^{29}$

"The purpose of the reform is to replace the Directive in effect from a teleological perspective which will criminalize travel for terrorist purposes, undertaking terrorist training as well as support activities conducted by networks and recruiters, as well as a tighter control of firearm trafficking, which demands an increase of international cooperation, while improving preventive action against radicalization."

The COSI on 16 September 2016 will be focused "on firearms, strengthening border controls, information, terrorist financing", provided that within the current perspective on criminal justice, the dissuasive purpose prevails over the traditional punitive intent. The aim is to create a new "common response" with "specific" measures, conceived for the concerted European fight against terrorism.

As it was already foreseen for 2015, we cannot postpone the supervision of current legislation if we wish to improve and facilitate the exchange of "loyal" information, reinforcing the "traçabilité," and harmonizing the "marquage" with common regulations in order to neutralize fire arms.

It is precisely because of the intensification and acceleration of terrorism, that the adoption of common and more adequate legislative measures seems of paramount importance, as it was graphically stressed in several statements (by the

29 Council of the European Union, Conclusions of the Council of the European Union and of the Member States meeting within the Council on enhancing the criminal justice response to radicalisation leading to terrorism and violent extremism, 2015, available at http://www.consilium.europa.eu/en/press/press-releases/2015/11/20-conclusions-radicalisation/, accessed 18 December 2015. 
President and Vice-president of the Commission), which went as far as to announce the creation of a "preventive arsenal."

It is therefore indisputable that there is a need within the legal frames both to harmonize the domestic laws of the Member States and to predict the adaptation of pre-established international parameters, since various "pre-existing" obligations can be deduced from them, such as the exchange of information between competent national authorities,. That is why the simplifying of the 2006 Frame Decision was foreseen and accompanied by the intelligence task in the execution of the law between the EU Member States.

This new perspective ${ }^{30}$ brings to the table a new classification within the Directive project to regulate new cases. The main aim is "to approximate the definition of terrorist offenses in all Member States by introducing a specific and common qualification of certain acts as terrorist offenses." It considers the motivation of the offender, taking into account two elements: the objective element, as "it refers to a list of serious criminal conducts" whose definition is made by reference to national law, and the subjective element, "as these acts are deemed to be terrorist offenses when committed with a specific intent."

States should criminalize the direction of, or participation in, the activities of terrorist groups, considered "by themselves" as independent criminal acts, which should be prosecuted as terrorist offenses (for example, the "attempt of recruitment and training, travel abroad with the purpose of participating in the activities of a terrorist group, and the financing of the various terrorist offenses"). These acts are also defined in the text of the Directive proposal (articles 3 and 4, Titles II and III). Such offenses do not require to be committed (article 15); the intent or knowledge of the perpetrator or potential perpetrator as to his conduct having a potential to lead to the commission of or the contribution to terrorist offenses are also included. The proposal is also focused on elements that should be proven in accordance with domestic law and, moreover, in accordance with the acquis on procedural rights and guarantees of the fundamental right to fair trial as enshrined in the European Convention of Human Rights and the Charter of Fundamental Rights.

In this vein, and as a response to one of the main concerns, stands the global regulation against the so-called "foreign fighters", traveling abroad for terrorism. The act of traveling is considered under some conditions, and with the intent and

30 Council of the European Union, Enhancing counter terrorism capabilities at EU level: European Counter Terrorism Centre (ECTC) at Europol and counter terrorism related information sharing, 2015, available at http://www.statewatch.org/news/2015/nov/eucouncil-europol-ECTC-14244-15.pdf, accessed 17 December 2015. 
purpose of participating in activities of a terrorist group, or to provide or receive training for terrorism. The provision uses the term "organization" in order to cover every conduct related to practical arrangements connected with the traveling and is completed by the term "facilitation" with the aim to cover any other conduct that does not fall within the term "organization," such as assisting the traveler in reaching his destination.

A further innovation of the proposal is the provision against "the financing of traveling abroad for terrorism," as stated by article 5 of the Additional Protocol and N.5 Recommendation of FATF. Financing terrorism is criminalized even when there is no specific link to a specific terrorist act. States are now bound in some of the terrorist related offenses because the proposal considers terrorist activity irrespectively of whether a terrorist offense has been committed. Under this provision, States must take measures to ensure that preparatory acts for these offenses are criminalized in domestic law.

In order to ensure the fight against the dissemination of messages through the Internet encouraging the commission of terrorist offenses or providing for terrorist expertise, art. 3 (1) of Framework Decision 2008/919/JHA was introduced, also to implement Articles 5 and 6 of the Council of Europe Convention on the prevention of terrorism. New offenses have been included in order to implement the Additional Protocol of the above-mentioned Convention. The proposal covers not only the offenses of receiving training or terrorism and traveling abroad for terrorism but also the receiving of training enabling the recipient to carry out or contribute to the commission of terrorist offenses. Furthermore, in line with Article 3 of the Protocol, it holds that a reception of training could take place either in person or through electronic media, that the use of the Internet for training should be considered as an offense, and that the perpetrator must normally take an active part in the training. However, the forms applicable to criminalize such activities remain in the domestic law "self-study."

Adapting regulations is a response to the carrying out of international engagements, through the Security Council Resolution 2178 (2014) regarding foreign terrorist fighters and its Protocol. On a regional level, the regulatory efforts made by the Convention to prevent terrorism and recommendations of the action group concerning the financing of terrorism are prompted within the Council of Europe. ${ }^{31}$ The adaptation rests on two nuclear ideas: a global approach and the consolidation

31 Financial Action Task Force (FATF), International Standars on combating money laudering and the financing of terrorism \& profileration, 2012, available at http://www. fatfgafi.org/media/fatf/documents/recommendations/pdfs/FATF_Recommendations. pdf, accesse 24 November 2015. 
of the acquis. The approach now required is necessarily "global", also in consonance with the new notion of security, as regards the existing loopholes and an effective response in the fight against them, taking advantage of the favorable climate of consensus regarding the heightened risk due to the crossing of borders. This nuclear idea is not foreign to the convenience of reaffirming, on a European level, the acquis in this matter, also guaranteeing its "accessibility", which is materialized through simplification. At the same time, the said proposal aspires to consolidate the acquis developed during the last thirteen years of application.

For this reason, both the Council and the Parliament agree on the articulation of legislative measures, which, according to the European Justice Council in its meeting in Riga, could allow "a common understanding of terrorism offenses in light of UNSCR 2178(2014)," or, as the text adopted by the Parliament on February, $11^{\text {th }}$ last stressed, "the need to harmonize criminalization of foreignfighter-related offenses and avoid prosecution gaps by updating the Framework Decision on Terrorism", which demands "a more coherent, comprehensive and aligned national criminal law provisions... across the EU to be able to effectively prevent and prosecute foreign terrorist fighters-related offenses and to respond in an appropriate manner to the increased cross-border practical legal challenges." ${ }^{32}$

Also in this spirit, the Commission, in its report justifying the Directive, deemed it a a first step which should open the path for further developments, since it mirrors a more ample engagement, which "will pave the way for the conclusion of the Additional Protocol and the Convention". Thus, it is also linked to the prevention of radicalization, which can develop into violent extremisms or even terrorist acts.

The Commission itself had already carried out very positive research in this area, stemming from the "Communication Preventing Radicalization to Terrorism and Violent Extremism, Strengthening the EU's response." 33 The High Level Conference in October 2015, whose purposes were to explore options in European criminal systems for dealing with foreign fighters, returnees and other violent religious extremists with terrorist motives, and to exchange experiences on appropriate responses to the phenomenon of radicalization in a prison context, as well as the possibility of integrating rehabilitation into the criminal justice response to foreign fighters/returnees. The 13 Justice Ministers and deputy justice ministers/

32 R. Harry, W. Richardson, P. Gordon, J. E. Moore, The economics cost of and consequences of terrorism, University of Southern California, New York, 2007.

33 European Commission, Preventing Radicalisation to terrorism and Violent Extremism: Strengthening the EU's Response, 2015, available at http://eur-lex.europa.eu/legalcontent/EN/TXT/?uri=COM:2013:0941:FIN, accessed 29 October 2015. 
state secretaries of the 17 EU Members State and the EU policy-makers agreed to join forces to find more concrete responses and solutions to deal with this common challenge: "preventing radicalization to violent extremism with special focus on prisons" is now considered essential, because the radicalized people in prisons have a considerable impact in terms of the risk of security. They suited the "Council of Europe Guidelines for prison and probation staff," 34 with the creation of an Excellence Centre linking "practitioners" and establishing a "network" which, according to the current Commission report, will facilitate the exchange of good practices and cement the "know how."35

The Radicalization Awareness Network (RAN) acts as a think tank for EU countries, gives support to priority third countries, and influences policy-making. As the legislation and the prison and probation systems differ between EU Member States, its recommendations provide an oversight of current lines of thinking amongst prison and probation practitioners, and give support to decision-making processes.

In her Opening Speech at the October High level Ministerial Conference, V. Jourova, the EU's Commissioner for Justice, Consumers and Gender Equality urged "to move on together identifying concrete actions... Key questions included how to reconcile prison and de-radicalization, how to reconcile prevention with repression and rehabilitation, and how to best detect early signs of radicalization." ${ }^{36}$ She also believed that the adaptation in question should be complemented by specific attention to the diversification of actors and the modification of their modus operandi.

Particular attention must be paid to the so-called "foreign terrorist fighters". Even if we acknowledge that they are not a new phenomenon, their current percentage is quite noteworthy and "unprecedented". Special attention is attached to actors traveling to the conflict areas, whether Syria or Iraq, either to take part in the combat or to receive training. A cohesion with the remaining EU policies is

34 Council of the European Union, Enhancing counter terrorism capabilities at EU level: European Counter Terrorism Centre (ECTC) at Europol and counter terrorism related information sharing, 2015, available at http://www.statewatch.org/news/2015/nov/eucouncil-europol-ECTC-14244-15.pdf, accessed 17 December 2015.

35 FRONTEX, Annual Risk Analysis 2014, 2015, available at http://frontex.europa.eu/assets/Publications/Risk_Analysis/Annual_Risk_Analysis_20 2015.

36 European Commission, High-Level Ministerial Conference Criminal justice response to radicalisation, 2015, available at http://ec.europa.eu/justice/events/response-radicalisation-2015/index_en.htm, accessed 17 November 2015. 
sought, since the relevance and interconnection both for European security policies and the internal security of the Union itself has been proven. According to Europol, since 2014 the information exchange has been favored, which should additionally be increased, since, by the end of November 2015, 1595 foreign terrorist fighters have been registered in SIENA (Secure Information Exchange Network Application) by virtue of the information provided only by EU Member States, 5 third parties, and Interpol.

The "complementarity" of the measure with those adopted is needed in order to freeze assets belonging to terrorists and said organizations by virtue of the Council Regulation of 2008 executing the Security Council Resolutions (UNSCR 1267 y 1390), as well as in relation to the so-called autonomous measures by the EU, adopted with regard to $\mathrm{Al}$ Qaeda. It was also stressed how the Directive regarding terrorist financing 2015/849/EU shows a preventive nature. ${ }^{37}$ Further on this line of reasoning, we can find the text of the specific Communication concerning Syria and Iraq returnees. ${ }^{38}$

The idea of focusing the current common effort on identifying the legal frame of this reality is clearly due to the proliferation of individuals acting in an isolated fashion. It now needs to reflect the reality of the so-called "home-grown terrorists," that is, radicalized lone attackers and "frustrated" terrorist travelers. The phenomenon has increased considerably over the last years, and they should be considered as future terrorists - perhaps, not now, when they are "plots" but in the future, when they might take part in tragic terrorist attacks.

We must pay utmost and specific attention to the changes in their modus operandi, which is increasingly worrying because of the shift from an essentially individualistic action to another, now arranged between groups or cells, whose actions can evolve in such a way that will magnify and transform the very scope of the attacks. This combination of means of action of several operative groups is more than predictable, even though it has not yet been generalized, because the attacks carried out in 2014 follow the formula of other attacks by "individual terrorists." The latest actions by France and Belgium have awoken the fear that such an orientation will be promoted in the near future, together with the circulation to other Member States. This risk must be carefully considered, as well as their very permanence in the European Union.

37 European Commission: Feasibility Study for an European Travel Information and Authorisation System (ETIAS) Final Report 16 November 2016.

38 European Commission, Elements for an EU regional strategy for Syria and Iraq as well as the Da'esh threat, 2015, available at http://ec.europa.eu/echo/files/news/20150206_ JOIN_en.pdf, accessed 19 November 2015. 
For this reason, the Directive Proposal's contents need to be adapted to the current reality. At the same, they should be adapted to the already established international parameters. The UN Security Council's view of terrorism in our day, as a threat to peace and security creates certain obligations for the States, which should adapt their behavior to the international agreements and standards, combining the duty of mutual respect of Human Rights and the rule of law.

The isolation of detainees has been criticized due to concerns that it will not be circumscribed to cases characterized by an urgent need to avoid dire consequences which can put in danger the life, freedom or physical integrity of a person, or by an urgent need for swift action by the court to avoid seriously compromising a criminal procedure. The national effort in the fight against terrorism should be also related, according to UN parameters, to the idea of efficacy with the adoption of instruments and measures facilitating investigations, with particular attention paid to the evolving nature of this phenomena. This may lead to a legal and positive obligation to guarantee, in their respective legal systems, a classification of different crimes linked to traveling to third party countries with different purposes related to terrorist activities. Article. 6 of the Resolution 2178 (2014) includes: "a) travel or attempted travel to a third country with the purpose of contributing to the commission of terrorist acts or the providing or receiving of training; $b$ ) the funding of such travel; c) the organization or facilitation of such travel."

The question is therefore to ensure the prosecution of such acts and their current modus operandi, avoiding the existing loopholes in criminal law (which we should remember are a by-product of already assumed international legal agreements).

The provision adequately addresses the purpose in Article 6 of the UN Resolution, since the 2015 Additional Protocol to the Convention for the Prevention of terrorism complements the classification of the Convention text itself, broadening the events alluded to in the universal resolution, as it includes: participation in an association or group or the purpose of terrorism (Article 2), receiving training for terrorism; traveling or attempting to travel for terrorism purposes (Article 4), providing or collecting funds for such travels (Article 5), and organizing and facilitating such travels (Article 6), although it also specifies the obligation to reinforce the occasional exchange of information between the State Parties (Article 7).

Regarding the current European legislation, whose alteration we are currently discussing, we should first of all remember that the EU has ratified both texts from the Council of Europe's Convention and Protocol, which also brings up the need to perfect the 2002 European regulation. The framework decision encompassed only certain terrorist acts, although it did pay particular attention to the participation 
in terrorist groups, in whose regard it incorporated financing, recruitment and training as well as laws concerning "aiding and abetting, incitement and attempt of terrorist offenses."

At the same time, these changes in legislation were expedited by virtue of the rising awareness of the true seriousness of our current situation, which also leads Member States to meet their individual obligations. The defense of rights and of the security of the citizens itself was necessary, according to the Directive 2012/29/EU. ${ }^{39}$

The momentum was started by the terrorist attacks of $13^{\text {th }}$ November in Paris, which "tragically illustrated that the risk can materialize, hence the need to scale up the EU-level response by adapting it to the threats." ${ }^{40}$

However, as distinct from the UN's text, the European text 2002/475/JHA which determines the need for "criminalization of terrorist financing to the extent that funding is provided to a terrorist group", is not as explicit and rigorous, since the Convention Protocol of the European Council already describes all crimes linked to terrorism, be it recruitment or travel with terrorist purposes, and stands in contrast to the European text, which does not require trips to be typified as having a terrorist intent: it "does not explicitly require the criminalization of being trained for terrorist purposes."

The obligation to control the said groups originates in the Convention regarding Terrorist Financing, developed in the Recommendation on the criminalization of the terrorist financing №5 adopted in 2012 by The Financial Action Task Force (FATF). The interpretative development of this text has allowed us to consider the financing from both sides, that is to say, both in terms of direct financing of the crime and in terms of indirect assistance in its perpetration. The clarification included traveling to the State of origin or residence with the purpose of "the planning or preparation of terrorist acts, as well as the providing or receiving of a terrorist training."

39 Directive 2012/29/EU of the European Parliament and the Council of 25 October 2012, Minimum standards on the rights, support and protection of victims of crime, and replacing Council Framework Decision 2001/220/JHA of 25 March 2001 (OJ L 315, 14.11.2012), 2012, available at http://eur-lex.europa.eu/legal-content/EN/TXT/PDF/?u ri=CELEX:32012L0029\&from=EN, accessed 27 November 2015.

40 European Commissions, Proposal for a Directive on combating terrorism and replacing Council Framework Decision 2002/475/JHA on combating terrorism combating terrorism, 2003, available at http://ec.europa.eu/dgs/home-affairs/what-we do/policies/europeanagendasecurity/legislativedocuments/docs/20151202_directive_on_combatting_terrorism_en.pdf, accessed 3 December 2015. 
The ultimate objective is correct in that it attempts to maximize its power of deterrence through legislative measures, which would allow to fill in the currently detected loopholes, which demand control of financing, organization and ease of travel, including material and logistic support, as well as procuring fire guns and explosives, shelter, means of transportation, and other wares.

The complexity of proving their belonging to a terrorist organization in practice, particularly if the individual has not had direct or physical contact with the organization itself, is undeniable. In the previously mentioned Seminar held in Madrid, the work of the Guardia Civil in creating their "Forensic Intelligence Reports," also called "Information Analysis reports," was greatly valued.

It does seem reasonable to assume that the lack of both gun and explosives control have made committing those crimes easier, and therefore the need to avoid access to fire arms and explosives, as well as access to gun dealers, becomes apparent.

Such measures, in turn, would require for the European Union to adopt an effective and necessarily joint response, since nowadays it is a well-known phenomenon and we must not forget that we are beyond the point of reacting to a novel phenomenon. The transient nature of activists implies a high number of countries being affected and calls for an effective response from multilateral forums.

Battling the terrorist threat is a European challenge that requires a European answer. The Commissioner for Justice, Consumers and Gender Equality, Vera Jourova, at the opening of ECLAN's $10^{\text {th }}$ anniversary, stated her priorities in European criminal justice and urged EU Members to tackle serious cross-border crime on various fronts, being careful to strike the right balance, fighting all forms of crimes (including jihadist terrorism and radicalization), combatting hate speech and hate crime, preventing the anti-Muslim hatred to spread. Another objective is to improve judicial cooperation between the criminal justice authorities of all Member States, with judicial cross-border cooperation, expanding the exchange of information on past criminal convictions to third country nationals and stateless people. She is launching infringement proceedings against Member States that have not yet transposed the three Framework Decisions on detention or ECRIS.

Among the issues still to be addressed by the EU's law is the conflict of jurisdiction on the transfer of proceedings and digital evidence. Also the digitalization of national legal systems to extract relevant data must be provided.

Those objectives are to be completed with packages on victims' rights, improving the procedural safeguards related to pre-trial detention. Another objective is to improve detention conditions and fight radicalization both inside and outside prisons. 
The text also reflects the particular situation of the victims themselves, who have a right to protection, since these attacks can affect everyone regardless of nationality. Security is indeed a primary responsibility of the State, and it has a margin of appraisal to adopt specifically relevant measures for safeguarding national and foreign citizens, and if applicable, for the protection of terrorism victims, which grants it an "added value," although it should include their compensation. The 2012/29/EU Directive assigned them a singular protection, and for this reason the current purpose is to incorporate specific dispositions to give substantial support to the victims in the guarantee of their rights. This effort must be started though a higher regulatory precision, establishing common definitions of terrorist action ex ante and ex post. Various "preparatory" actions should be included, such as those deemed necessary for committing the crime, as well as "material assistance" and "complicity;" also a posteriori actions should be taken into account, such as providing a necessary material help (e.g. transportation of the perpetrators of terrorist attacks) and financing the attacks.

\section{Conclusion}

The supervision of current legislation will harmonize domestic laws, allowing States to adapt their behavior to preexisting international obligations and parameters. The Proposal hardens offenses classified as recruiting, training, and distribution of propaganda. In an innovative stance, it indicts behaviors linked to terrorist activities, elevating to the status of offenses the possible movements of foreign fighters, as well as financing and aiding of movements within or outside the Union.

The increasingly stronger link between internal and external challenges requires meeting common objectives. It is therefore indisputable that it demands an effective and integrated use of the EU's broad range of instruments to give an effective response in the fight against terrorism, harmonizing criminalization to prevent and prosecute foreign terrorist fighters. The States also commit to investigate training activities which could lead to terrorist acts, improving relations between international organizations by active diplomatic efforts on the part of the High Representative and the Member States, involving all government agencies at different levels, reinforcing cooperation, and responding in an appropriate manner to the increasing cross-border practical challenges. Simultaneously, the action plan improves gun and explosive (as well as substances involved in their manufacture) traffic control,s as it restricts fire gun purchases.

In order to accomplish these objectives, the EU must embark on a dialogue on security with key strategic partners and neighboring countries. The future action 
should be linked to the EU's financial instruments maximizing the added value of the EU's measures for information exchange, and operational cooperation.

The lessons drawn from the past must help us to tackle this new phenomenon, deepening our knowledge through a necessarily holistic approach. The abilities sadly acquired through the Spanish experience should contribute to the development of international cooperation in the common fight against terrorism.

\section{References}

R. Bjarnason, A Report from the democracy incubator hackathon, World Forum for Democracy 2015, 21.12.2015, available at https://www.opendemocracy. net/wfd/robert-bjarnason/world-forum-for democracy-2015-report-fromdemocracy-incubator-hackathon, accessed 12 January 2016.

I. Bremmer, How terror could kill the European project, “Time” vol. 186 no. 22-237, 2015.

L. de la Corte Ibañez, H. Hristowa Gergova, El terrorismo como objeto de estudio: algunas notas introductoria, "Studia" no. 14, 2011.

Council of the European Union, Response to foreign terrorist fighters and recent terrorist attacks in Europe, available at http://www.consilium.europa.eu/en/ meetings/jha/2015/06/15-16/, 2015, accessed 21 January 2016.

Council of the European Union, Draft Council Conclusions on the Renewed European Union Internal Security Strategy 2015-2020, 2015, available at http://www. consilium.europa.eu/en/meetings/jha/2015/06/15-16/, accessed 21 January 2016.

Council of the European Union, Conclusions of the Council of the European Union and of the Member States meeting within the Council on enhancing the criminal justice response to radicalisation leading to terrorism and violent extremism, 2015, available at http://www.consilium.europa.eu/en/press/pressreleases/2015/11/20-conclusions-radicalisation/, accessed 18 December 2015.

Council of the European Union, Draft Conclusions of the Council of the EU and of the Member States meeting within the Council on Counter-Terrorism, 2015, available at http://www.statewatch.org/news/2015/nov/eu-jha-20-nov-draftconclusions-14298-15.pdf, accessed 4 December 2015.

Council of the European Union, Conclusions of the Council of the European Union and of the Member States meeting within the Council on enhancing the criminal justice response to radicalisation leading to terrorism and violent extremism, 2015, available at http://www.consilium.europa.eu/en/press/pressreleases/2015/11/20-conclusions-radicalisation/, accessed 18 December 2015.

Council of the European Union, Enhancing counter terrorism capabilities at EU level: European Counter Terrorism Centre (ECTC) at Europol and 
counter terrorism related information sharing, 2015, available at http://www. statewatch.org/news/2015/nov/eu-council-europol-ECTC-14244-15.pdf, accessed 17 December 2015.

M. Crenshaw, The psychology of political terrorism, in: Policital Psychology. Key readings J. T. Jost, J. Sidanius (eds.), Pshicology Press, New York, 2004.

Directive 2012/29/EU of the European Parliament and the Council of 25 October 2012, Minimum standards on the rights, support and protection of victims of crime, and replacing Council Framework Decision 2001/220/JHA of 25 March 2001 (OJ L 315, 14. 11. 2012), 2012, available at http://eur-lex.europa.eu/legalcontent/EN/TXT/PDF/?uri=CELEX:32012L0029\&from=EN, accessed 27 November 2015.

European Commission, Commission Work Programme 2016, 2016, available at http://ec.europa.eu/atwork/pdf/cwp_2016_annex_i_en.pdf, accessed 20 January 2016.

European Commission, Preventing Radicalisation to terrorism and Violent Extremism: Strengthening the EU's Response, 2015, available at http://eur-lex.europa. eu/legal-content/EN/TXT/?uri=COM:2013:0941:FIN, accessed 29 October 2015.

European Commission, High-Level Ministerial Conference Criminal justice response to radicalisation, 2015, available at http://ec.europa.eu/justice/events/ response-radicalisation-2015/index_en.htm, accessed 17 November 2015.

European Commission, Elements for an EU regional strategy for Syria and Iraq as well as the Da'esh threat, 2015, available at http://ec.europa.eu/echo/files/ news/20150206_JOIN_en.pdf, accessed 19 November 2015.

European Commissions, Proposal for a Directive on combating terrorism and replacing Council Framework Decision 2002/475/JHA on combating terrorism combating terrorism, 2003, available at http://ec.europa.eu/dgs/homeaffairs/what-we do/policies/europeanagendasecurity/legislativedocuments/ docs/20151202_directive_on_combatting_terrorism_en.pdf, accessed 3 December 2015.

European Council, Conclusions of European Council meeting 15 October 2015, 2015, available at http://www.consilium.europa.eu/en/press/press-releases/2015/10/16euco-conclusions/, accessed 20 January 2016.

European Parliament, Preventing radicalisation in the EU, 2015, available at http://www.europarl.europa.eu/RegData/etudes/ATAG/2015/571342/EPRS_ ATA\%282015\%29571342_EN.pdf, accessed 15 December 2015.

Europol, EU Terrorism Situation and Trend Report, 2015, available at https://www. europol.europa.eu/content/european-union-terrorism-situation-and, accessed 14 January 2016. 
Europol, EU Terrorism Situation and Trend Report, 2015, available at https://www. europol.europa.eu/content/european-union-terrorism-situation-and, accessed 14 January 2016.

Financial Action Task Force (FATF), International Standars on combating money laudering and the financing of terrorism \& profileration, 2012, available at http:// www.fatfgafi.org/media/fatf/documents/recommendations/pdfs/FATF_Recommendations.pdf, accessed 24 November 2015.

F. Foley, Políticas antiterroristas en Europa, available at http://fundacion.unirioja. es/formacion_cursos/view/312/sub:2354, accessed 7 December 2015.

FRONTEX, Annual Risk Analysis 2014, 2015, available at http://frontex.europa.eu/ assets/Publications/Risk_Analysis/Annual_Risk_Analysis_2014.pdf, accessed 3 November 2015.

R. Harry, W. Richardson, P. Gordon, J. E. Moore, The economics cost of and consequences of terrorism, University of Southern California, New York, 2007.

J. Jordán, P. del Pozo (eds.) Terrorismo sin fronteras. Actores escenarios y respuestas en un mundo global, Aranzadi, Pamplona 2010.

J. Jordán, El terrorismo yijhadista en España:evolución después del 11M, 2009, available at http://www.realinstitutoelcano.org/wps/portal/rielcano/contenido?WCM_GLOBAL_CONTEXT=/elcano/elcano_es/programas/terrorismo+global/publicaciones/publ-amenaza+espana/dt7-2009, accessed 9 November 2015.

J. Jordan, Evolución organizativa de la militancia jihadista en España, 2014, available at http://www.realinstitutoelcano.org/wps/portal/web/rielcano_es/ contenido?WCM_GLOBAL_CONTEXT=/elcano/elcano_es/zonas_es/ ari12-2014-jordan-evolucion-organizativa-militancia-yihadista-espana, accessed 9 November 2015.

B. M. Juergensmeyer, Terrorismo religioso. El auge global de la violencia religiosa, Siglo XXI, Madrid 2001.

K. Malik, Europe's Dangerous Multiculturalism. Why the Continent Fails Minority Groups, 2015, available at https://www.foreignaffairs.com/articles/westerneurope/2015-12-08/europes-dangerous, accessed 18 December 2015.

Real Instituto Elcano, III Foro Elcano sobre Terrorismo Global, 2015, available at http:// www.realinstitutoelcano.org/wps/portal/web/rielcano_es/actividad?WCM GLOBAL_CONTEXT=/elcano/elcano_es/calendario/actividades/iii-foro-elcano-terrorismo-global, accessed 10 January 2016.

F. Reinares, C. García Calvo, Terrorist network and organisations aspects of the current jihadist mobilisation in Spain, 2015, available at =//Elcano/Elcano_es/ dt17-2015reinaresgarciacalvo.www.realinstitutoelcano.org/wps/portal/Web/ rielcanoes/contenido?WCMGlobal-context, accessed 9 January 2016 
M. Sageman, Understanding terrorism networks, University of Pennsylvania Press, Philadelphia, 2004.

J. R. Thackray, Dictionary of Terrorism, Routledge, London 2004.

United Nations Strategies UN 2006 Global Counter-Terrorism Strategy, 2015, available at http://www.Un.org/terrorism/strategy-counter-terrorism.shtml, accessed 9 November 2015.

P. Wilkinson, Terrorism versus democracy. The liberal State response, Frank Cass, London 2005. 


\section{Sebastian Wojciechowski}

\section{Reasons of Contemporary Terrorism. An Analysis of Main Determinants}

\section{Introduction ${ }^{1}$}

When analyzing the reasons for terrorism, a few key questions need to be asked. What makes terrorism escalate? Is it possible to identify one or several main sources of terrorism? Are certain reasons for terrorism characteristic (specific) of only a given historical period or region? Is there a single universal model (classification) of sources of terrorism, and what elements should it encompass? The fundamental objective of this text is an attempt to answer the above questions, together with:

A. Discussing the reasons for terrorism as presented in the literature on the subject (through an analysis of selected examples).

B. Presenting a handful of classifications of the sources of terrorism (including one proposed by the author).

C. Presenting the hybridity of causes of terrorism which emphasizes the multiplicity and complexity of sources of terrorism and indicates the mutual relations between them. The key role is played by three main groups of determinants, namely ideological, socio-economic and psychological reasons, as well as their mutual interactions.

It should be stressed that the discussion that follows does not aspire to be an exhaustive analysis of the reasons behind terrorism, but it rather aims to contribute to the ongoing discussion on the subject in question. It also involves the presentation of a new concept and its components.

\section{Causes of Terrorism}

The reasons for terrorism are an example of the so-called system of communicating vessels. This means that they are a sum total of a plethora of different elements, their mutual relations and the conditions that influence them. Therefore, they are

1 This article is the revised and updated version of the analysis included in the book: S. Wojciechowski, The Hybridity of Terrorism. Understanding Contemporary Terrorism: Logos Verlag, Berlin 2013. 
a "system" coupled with other elements of terrorism (such as tactics, strategies, or the consequences of terrorist activities).

The literature on the subject reveals significant disparities when indicating the main reasons for terrorism. P. Wilkinson, for example, names the following generators of terrorism: ethnic, religious or ideological conflicts, poverty, negative aftermath of modernization, injustice, revolutionary sentiments among society, weak governments or an internal power struggle. He refers to an extensive range of determinants from various categories of political, social, economic, cultural, and psychological nature. ${ }^{2}$ Similar factors are pointed out by $\mathrm{H}$. Hall, who sees the sources of terrorism in the political, religious and ideological realms, or in response to violence. ${ }^{3}$

Another list has been compiled by C. Sterling, who indicates the following motives for terrorist activity: ${ }^{4}$

Initiative taken on one's own behalf or on behalf of a certain group;

A desire to attract attention to oneself or to draw the public's attention to certain issues;

Demonstration of an aversion to and disrespect for the existing legal order, the principles of social coexistence, or the principles of a given political or religious group;

Attempt to undermine the authorities and their political role;

Attempt to coerce government to behave in a certain way;

Revenge for a certain activity of government or its representatives;

Justification of the attack with a certain ideology.

In the opinion of M. Crenshaw, there are four key motives for terrorist activities: ${ }^{5}$ the hope to change the status quo, the need to belong to a group, the attempt to improve social status, and the desire to obtain material reward.

2 P. Wilkinson, Political Terrorism, Macmillan Press, London 1974.

3 H. Hall (ed.), Terrorism: Strategies for Intervention, The Haworth Press, Binghamton 2002 , p. 2.

4 C. Sterling, The Terror Network, The Secret War of International Terrorism, Henry Holt \& Co, New York 1981.

5 M. Crenshaw, An Organizational Approach to the Analysis of Political Terrorism", "Orbis" no. 29 , 1985 , pp. $465-488$. 


\section{Taxonomy of Reasons}

Even on the basis of the several selected examples that are presented above, one can observe the considerable diversity of the sources of terrorism. This calls for some order to be introduced. In the opinion of certain specialists, it is difficult to develop a single, universal model of reasons for terrorism to encompass different forms and geographical regions. An example is provided by F. Gross, who identified a separate mechanism of terrorism emerging in democratic societies in contrast to the mechanism present in autocratic states. The former applies to the United States, among other countries, and focuses primarily on the terrorism generated by Muslim groups, including Al Qaeda. Among the factors that apply here, F. Gross mentions the pressure of US global domination, the "holy war" syndrome, or undermining of American supremacy. The latter model refers primarily to Eastern Europe, where the key form involves individual terrorism aimed at the representatives or promoters of the democratic system. ${ }^{6}$

In an attempt to classify the sources of terrorism, one can divide them into simple and complex ones. The former group characterizes only selected instances of terrorism, where a single, clearly defined motive predominates, for instance, the attacks executed by Ted Kaczynski, or the so-called anti-abortion terrorism. The latter group involves complex reasons, where various motives, e.g. religious, ethnic, political, overlap. This applies to a majority of cases of terrorism, as exemplified by Palestinian or Northern-Irish terrorism.

In the opinion of A. Cronin, all reasons for terrorism can be divided into four levels. The first one is the individual level. The main point of reference is provided by external factors that lead an individual to become involved in terrorist activities, and the personal traits making such involvement more or less likely. The second level is of organizational nature. It is related to a group dynamics and the issues of group identification. Shared ideology, belief systems, and the activities of a given group are of key significance. The third level is related to the activities of the state and the need to analyze the different ways in which states take advantage of terrorism. Finally, the fourth level is focused on the international system and

6 F. Gross, Violence in Politics: Terror and Political Assassination in Eastern Europe and Russia, Mouton, Hague 1972, cit. after A. Schmid, A. Jongman, Political Terrorism. A New Guide to Actors, Authors, Concepts, Data Bases, Theories and Literature, Transaction Publishers, Amsterdam-Oxford-New York 1988, p. 124. 
refers to Samuel Huntington's theory of the clash of civilizations, or the transformations that accompany globalization, secularization, etc. ${ }^{7}$

The experts from the National Research Council of the National Academies in Washington also emphasize that it is necessary to comprehensively analyze the reasons for terrorism, claiming that the separate analysis of individual reasons is erroneous. ${ }^{8}$ They justify this both by their multiplicity and variety, as well as the complexity of the mutual relations between different reasons. In their opinion, two levels of reasons for terrorism can be distinguished. One concerns historical, social, political, and cultural conditions which facilitate the escalation of terrorism. The other refers to direct determinants, such as motivation, group, and ideological or organizational factors that culminate in terrorist activity.

Another division of motives for terrorist activity has been designed by J. Horgan, who identified three groups of factors: ${ }^{9}$

A. Injustice. The sense of injustice and harm is one of the strongest psychological conditions. This may concern an individual, group or a given situation, and so on, leading to various responses, including the use of violence. The significance of the "sense of injustice" is also stressed by J. Rossa, who distinguishes economic, ethnic, racial, legal, political, religious and social harms. ${ }^{10}$

B. Identity. The sense of identity is considered to be a significant element of human existence. In their search for identity, or as a consequence of an "underestimated" level of identity, some individuals begin to identify with radical groups, including terrorist groups, as exemplified by the numerous members of Al Qaeda, IRA, Hamas and many other, similar organizations.

C. Membership. The sense of membership is another significant element of human personality. R. Luckabaugh emphasizes it, observing that "the true reason

7 A. Cronin, Sources of Contemporary Terrorism in Attacking Terrorism, in: Elements of a Grand Strategy A. Cronin, J. Ludes (eds.), Georgetown University Press, Washington 2004, pp. 19-43.

8 F. Mitchell (ed.) Terrorism. Perspectives from the Behavioral and Social Science. Washington: Committee on Science and Technology for Countering Terrorism, Center for Social and Economic Studies, National Research Council of the National Academies, 2002.

9 J. Horgan, The Search for the Terrorist Personality, in: Terrorists, Victims and Society. Psychological Perspectives on Terrorism and its Consequence A. Silke (ed.), John Wiley \& Sons, London 2003, pp. 3-26.

J. Horgan, The Psychology of Terrorism, Routledge, London-New York 2005.

10 J. Rossa, Structural Causes of Oppositional Political Terrorism, "Journal of Peace Research" 1993, no. 30, p. 326. 
to become terrorists is the need for membership of some group of people."11 A terrorist organization can become the main, or sometimes the only community a potential terrorist can identify with.

However, A. Wejkszner divides the reasons for modern terrorism into the following categories. ${ }^{12}$ One source is cultural. A broader analysis is founded on numerous concepts, including those developed by S. Huntington, E. Staub, F. Moghaddam, O. Roy. In this approach, terrorist organizations use violence as a consequence of isolation, finding violence an efficient means of social destabilization, a "war of cultures," or the so-called "cultural shock."13 Another group of factors distinguished by A. Wejkszner involves politico-organizational determinants. On the one hand, they concern the issue of state sponsorship of terrorism, on the other, they concentrate around the issues that allow the preparation or execution of specified terrorist actions in the most efficient manner. ${ }^{14}$ The third group of conditions that influences the escalation of terrorism involves socio-economic factors. The elements discussed here include globalization, neocolonialism, or consumerism. Another group of sources of terrorism concerns technology. Technical progress has an indisputable influence on the majority of social phenomena and processes in the modern world, including terrorism. What is meant here is mainly its influence on the strategy and tactics employed by terrorists as well as by the formations that combat them.

Can technical progress provide a direct stimulus for terrorism, though? If so, how is it done? J. Adamski, for example, explains this dependence in the following way: progress "stimulates the development of terrorism in its practical aspect," ${ }^{\prime 1}$ i.e. in terms of access to modern technology or advanced weapons. Thus it has a direct impact on the efficiency of terrorist activities and generates new kinds of terrorism, such as cyberterrorism. Other authors point to the unequal

11 R. Luckabaugh, J. Cangemi, C. Kowalski, Terrorist Behavior and US Foreign Policy. Who is the Enemy? Some Psychological and Political Perspectives, "Psychology" no. 34, 2007, pp. $1-15$.

12 A. Wejkszner, Ewolucja terroryzmu motywowanego ideologia religijna na przykładzie salafickiego ruchu dżihadu, Wydawnictwo Naukowe Wydziału Nauk Politycznych i Dziennikarstwa UAM, Poznań 2010, pp. 40-46.

13 O. Roy, Terrorism and Deculturation, in: The Roots of Terrorism. (Vol. 1 Democracy and Terrorism) L. Richardson (ed.), Routledge, New York -London 2006; S.P. Huntington, The Clash of Civilizations and the Remaking of World Order, Touchstone, New York 1997.

14 D. Byman, Deadly Connections, State that Sponsor Terrorism, Cambridge University Press, Cambridge 2007, p. 40.

15 J. Adamski, Nowe technologie w służbie terrorystów, Wydawnictwo Trio, Warsaw 2007, p. 7. 
opportunities concerning the use technological progress and the fact that this makes social divisions even more acute.

An extensive classification of the sources of terrorism has been proposed by R. Kosta, who divided them into four basic groups: socio-economic, historicopolitical, sociological, and psychological. ${ }^{16}$ The first category is related to such phenomena as economic crises, social tensions, instances of ethnic or social discrimination, and the disparity between reality and what the media show. Terrorism may also result from economic backwardness, illiteracy, demographic growth, social disproportions, aggressive policies of large companies, as well as globalization or reduced social spending. The range of factors presented above is thus quite extensive and varied. The second group of sources of terrorism indicated by R. Kosta concerns historico-political conditions. Their origins can be found in the demands that human rights be respected, among many other factors. In the opinion of M. Brewer, the analysis of historico-political sources of the activities of such organizations as the Red Army Faction or the Tamil Tigers ${ }^{17}$ should also be perceived in relation to postcolonial conflicts and respect for the rule of law.

Another category deals with sociological reasons. R. Kosta couples them with a so-called "atmosphere of violence." This atmosphere is particularly observable in some Muslim states (e.g. Algeria, Afghanistan), but also in Europe (Northern Ireland, former Yugoslavia) or South America (Columbia, Mexico, etc.). The fourth group embraces psychological sources. To a large extent they are a consequence of serious psychological imbalances in the perpetrators, including excessive selfesteem. This point of view is also shared by R. Robins and J. Post, when they emphasize that a charismatic leader with paranoid traits can frequently persuade people with similar views to share certain ideas. ${ }^{18}$

A slightly different method for classifying sources of terrorism is presented by the authors of International Encyclopedia of Terrorism, ${ }^{19}$ who distinguish three basic kinds of sources of terrorism. The first concerns various ideas of a nationalist or fundamentalist nature. The second category results from the intention to execute or maintain certain social changes. This can be based on anarchist, left-wing or

16 R. Kosta, Terroryzm jako zagrożenie dla bezpieczeństwa cywilizacji zachodniej w XXI wieku, Wydawnictwo Adam Marszałek, Toruń 2007, p. 23.

17 M. Brewer, Kryteria typologii terroryzmu, in: Encyklopedia terroryzmu, Wydawnictwo Bellona, Warsaw 2004, pp. 190-192.

18 R. Robins, J. Post, Paranoja polityczna. Psychopatologia nienawiści, Wydawnictwo Książka i Wiedza, Warsaw 1999, pp. 185-186.

19 M. Crenshaw, J. Pimlott (eds.), International Encyclopedia of Terrorism, Routledge, London-Chicago 1998, pp. 189-190. 
right-wing approaches. The last category involves psychological determinants that characterize both terrorists and their victims.

T. Bjørg divides the reasons for terrorism into four groups: ${ }^{20}$

A. Structural reasons, which, in his view, include demographic imbalance, globalization, modernization, urbanization, migration and social changes, among other things.

B. The so-called "accelerators," which are not the primary reasons, but which nonetheless stimulate interests in terrorism or make it easier to use terrorist means (e.g. weakening of state structures, or easy access to weapons).

C. Motivational reasons, involving for example a sense of injustice that may motivate some individuals to take specific steps.

D. "Detonators" that provide the initial spark for terrorist activities both on an individual and group level (e.g. Bloody Sunday in Ireland in 1972).

Yet another method for categorizing the sources of terrorism is their division into six categories, devised by this author: A. Religious and cultural sources; B. Territorial and ethnic sources; C. Socio-economic conditions; D. Politico-historical reasons; E. Psychological sources of terrorism; F. Other selected reasons.

A. Religious and cultural sources. Various surveys and analyses show that over the years the role of religious factors that inspire terrorism is increasing. For example, in the 1980s only a small proportion of terrorist attacks in the world stemmed from religious motivations. At present, this proportion is globally high ${ }^{21}$. Its precise level depends inter alia on the geographical region; being high in the Middle East or in Asia and relatively low in, say, Latin America. Escalation of terrorism motivated by religious factors is a result of Al Qaeda and ISIS activities and other related organizations. A significant factor leading to the escalation of terrorism can be related not only to cultural differences (cf. Huntington's clash of civilizations theory ${ }^{22}$ but also to the fear that they may "disappear" and different cultures will become somewhat universal.

B. Territorial and ethnic sources. There are approximately 200 recognized states in the modern world, and around 3,500 large nations. ${ }^{23}$ This means that

20 T. Bjørg, Root Causes of Terrorism. Myths, Reality and Ways Forward, Routledge, LondonNew York 2005.

21 RAND Corporation and St. Andrews University in Edinburgh, available at http://www. rand.org, accessed 2 February 2016.

22 S.P. Huntington, The Clash of Civilizations...op.cit.

23 E. Gellner, Nation and Nationalism, Nations and nationalism ( $2^{\text {nd }}$ ed.), Blackwell Publishing, Oxford 2006. 
only a few nations have their own states, which produces a series of different consequences. While a majority of nations have accepted the fact of being deprived of their own state, there are groups that use various measures (ranging from negotiation to terrorist activities) to change the situation and win or regain their statehood (e.g. some Basques, Kurds, Chechens, Palestinians, etc.). We are faced here with a classic conflict of interests that involves territory, ethnic identity, and other (e.g. political or ideological) factors. This is reflected in the activities of ISIS, Hamas, Hezbollah, IRA, ETA, and so on.

C. Socio-economic conditions. Experts disagree on the importance and influence of specific economic factors concerning terrorism. This can be well illustrated by the issue of poverty (destitution) as a trigger of terrorism, or the relations between terrorism and profound financial disparities present in a given territory. Another issue is that of financing of terrorism. ${ }^{24}$

D. Politico-historical reasons. Considering the various factors that generate terrorism, one needs to emphasize the importance of historical conditions. The memories of injustices suffered (whether real or imagined), disputes rooted in history, and a range of animosities can stimulate the emergence and escalation of radical attitudes, terrorism being one of them. Whether in the past or present, terrorism has frequently been connected with the policies of great powers, such as Ancient Rome (the terrorist acts of the Zealots or Sicarii), Russia (Narodnaya Volya), Turkey (Kurdish or Ormian radicals), Austria-Hungary (Serb nationalists), Great Britain (Irish nationalists), and so on. At present, this is illustrated by the attacks of Al Qaeda (aimed against US interests), Chechen terrorists (against the Russian Federation) or Urghuy terrorists (against China). Another significant historical factor that has profoundly influenced the escalation of terrorism has been the collapse of the communist system. It has brought about a rapid and radical change in international relations, but has also made it easier for various extremist organizations, including terrorist ones, to operate, which has stimulated increased activity.

E. Psychological sources of terrorism. The process of the emergence and formation of terrorism is to a large extent related to psychological factors, and it is strictly coupled with issues of hatred, prejudices, familiarity and alienation, intolerance, injustice, retaliation, trauma, and so on. We frequently deal with terrorism when a certain individual or group considers a given idea or approach to be ultimately the highest value that all other issues should be subordinated to, including one's own life and the life of a person's nearest and dearest. A range of

24 C. Clarke, Terrorism, INC. The Financing of Terrorism, Insurgency, and Irregular Warfare, Praeger Security International, Santa Barbara 2015. 
psychopathic attitudes also plays an important role here, as is well exemplified by Anders Breivik ${ }^{25}$ and numerous suicidal terrorists. J. Horgan presents it in the following way: "We can easily quote the arguments that support the theory of psychopathy as a likely feature of terrorist behavior. Terrorists intentionally get involved in a destructive activity resulting in suffering, death and other consequences, and they willingly assume responsibility for such activity."26

F. Other selected reasons. Apart from the above-presented sources of terrorism there is also a range of other factors that can contribute to the manifestation or escalation of terrorism. The following sources are among them:

- Globalization and its consequences. Some experts include globalization, and the processes that accompany it, among the factors that influence terrorism. In this case globalization can be seen as a threat to the interests, values or attitudes of individuals or groups. This is emphasized by M. Stevens, ${ }^{27}$ who points to three main threats to local communities posed by globalization. One concerns the weakening of the position of the community, which follows from the economic burdens imposed on its citizens, or the introduction of social transformations that may bring about frustration or aggression, which finds its expression in terrorism, among other things. Another concerns the fact that globalization can threaten local societies, posing a threat to such elements as their local identity. The final threat pertains to a scenario where globalizationrelated processes, including the furtherance of individual rights, among other things, can stimulate conflicts on an inter-group or inter-cultural level.

- Activities of leaders and elites. Terrorism can be generated "downwards", as it were, when it is inspired by political, social or religious leaders. It may provide a means to overthrow authorities or win power, serve as a pretext to reject responsibility for problems, and so on. Thus it can serve the implementation of both immediate goals and long-term objectives. State authorities may constitute another factor generating terrorism. Their role can be quite varied. Primarily, they play a positive role, combating given manifestations of terrorism. However, a state can also be a negative factor, supporting or actually running terrorist activities itself. We can see an interesting relation here, where the potential of a

25 E. Humphrys, G. Rundle, T. Tietze (eds.), ON UTØYA: Anders Breivik, Right Terror, Racism and Europe, Elguta Press, London 2011.

26 J. Horgan, The Search for the Terrorist...op.cit.

27 M. Stevens, The Unanticipated Consequences of Globalization. Contextualizing Terrorism" in: The Psychology of Terrorism (Vol III. Theoretical Understandings, and Perspectives) S. Stout (ed.), Greenwood Publishing Group, Westport 2002, p. 39. 
state or its institutions can be used by terrorist organizations, but also where terrorist organizations can be a tool for state structures. This has been exemplified by Iraq, Iran, South Korea, Sudan, Syria or Libya, which have all collaborated with terrorist organizations at some stage. In his analysis of the different reasons for terrorism B. Hoffman emphasizes the desire for power. "Terrorism is present wherever politics and violence overlap in a hope to rule. Terrorism is always about striving for power: the power that is necessary to dominate and coerce, threaten and control, and eventually implement a radical political change."28 Striving for power can have more than a political or religious dimension, and it can involve the psychological sense of being in power and the desire to dominate, and enjoy the splendor, and so on that accompanies power.

- Migration processes. Mass migration processes and all their negative consequences can constitute a significant source of terrorism, as well as result from it. Such a situation can be observed as a result of the migration crisis which tackles Europe. This is not only the case in Europe, though, as evidenced by the situation in the US, Canada, or Australia, and so on. The inflow of immigrants or the presence of huge immigrant communities is frequently taken advantage of by terrorist organizations seeking new recruits, logistic or financial support, and so on. On the other hand, immigrants and the institutions supporting them more and more frequently become the targets of attacks, which can be exemplified by the 2015 events occurring in many EU countries.

- Domino/avalanche effect. The domino (avalanche) effect is another determinant that generates terrorism. It consists in the fact that an escalation of terrorism in one state may be coupled with similar events in neighboring countries (to take the example of the narcoterrorist organizations in Latin America). One variation involves a mechanism in which terrorism within one nation is transferred to some members of the same nation living in other states (e.g. Basque, Chechen, Kurdish, Northern Irish extremists, etc.).

- The role of the media. Another issue that is frequently examined is the influence the media exert on terrorism, its forms, evolution, or reasons, and so on. The media are often recognized as an indirect determinant that influences the presence and escalation of terrorism in different ways and to various extents. This opinion is shared by some academics, politicians, and journalists. To some degree, W. Laqueur expressed this view saying that "terrorists need the media, and the media find all the components of an exciting story in terrorism." 29

28 B. Hoffman, Inside Terrorism, Columbia University Press, London 1998, p. 174.

29 W. Laqueur, The Age of Terrorism, Little Brown, Boston 2007, pp. 16-18. 
It can be observed on the basis of the above examples that academic descriptions refer to an extensive range of reasons for terrorism and their classification. A certain similarity of approaches can be noted among some, which offers a good starting point to develop a more comprehensive concept of the sources of modern terrorism.

\section{Hybridity of Reasons}

Hybridity of causes of terrorism is understood as the criss-crossing, complementing or combining of numerous different sources of terrorism, such as political, ethnic, religious and economic aspects, and so on. These processes occur to varying degrees and depend on geopolitical conditions, the type of terrorism, the period concerned, and so on. Therefore, hybridity considerably influences not only the nature or range of modern terrorism, but also how it can be understood or defeated.

The following assumptions can form the fundamental elements of the hybridity of causes of terrorism:

4.1. Not only do the multitude and diversity of reasons for terrorism need to be taken into account, but also the direct and indirect relations (interactions) that occur among them affecting the range, force or significance of their influence. In this understanding, the reasons for terrorism are treated as a part (a subsystem) of a terrorist system. The same factors frequently influence terrorism (to different degrees) over the long term and in many cases they are likely to occur also in the future, as is the case with ethnic or religious determinants.

More than once the sources of terrorism are characterized by the dynamics with which they occur. This concerns, among others: the strength of impact of a given source; the geographical territory where a given reason for terrorism occurs; the relations between individual sources of terrorism.

4.2. To investigate the issue of the reasons for terrorism in depth calls for a detailed analysis of the following components:

a - reasons for terrorism (e.g. $x, y, z, \ldots)$,

b - relations among the reasons for terrorism,

c - factors that are not directly linked to terrorism, but can influence its sources, e.g. economic situation, wars and conflicts, and so on.

However, a question arises of whether the above elements are sufficient to reach a comprehensive understanding of the sources of terrorism? Is an analysis presented in this manner possible in the first place? Perhaps, this model should be expanded to include one more element, " $\mathrm{d}$ " - the relations between these reasons and the other 
elements of terrorism (e.g. types of terrorism, its manifestations, features, or consequences), which are related to the sources of terrorism to a greater or lesser extent.

4.3. The hybridity of causes of terrorism assumes the presence of four principal classifications of reasons for terrorism. They divide the sources of terrorism in terms of the following:
A. territorial range,
B. subjective reasons,
C. time of occurrence,
D. the evolution of the reasons.

A. The following reasons can be distinguished with respect to their territorial range:

a. Local reasons for terrorism. They occur only in a given location and are related to the local political or social situation (as is the case of the Zapatista National Liberation Army (EZLN), the People Versus Gangsterism and Drugs (PAGAD) organization, or the Tamil Tigers).

b. Regional reasons for terrorism. In this case the same factor, or a group of factors, results in the escalation of terrorism in several, separate geographical locations. The examples include Kurdish or Palestinian terrorism.

c. Global reasons for terrorism. These are the cases when the same reason, or a group of reasons, affects many different parts of the world, as is the case with Muslim fundamentalism.

The above division is not always clear-cut. There are sources of terrorism that are difficult to classify unanimously. For example, the terrorist activity of the "Unabomber" (T. Kaczynski) falls under the category "A" described above, but it can also be classified as a manifestation of radical alterglobalism.

Figure 1: Division of reasons for terrorism due to their territorial range
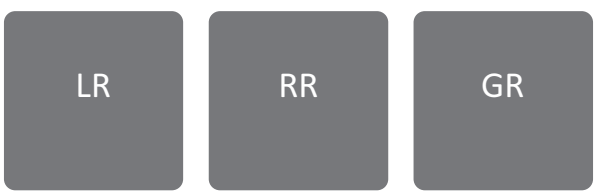

LR - local reasons for terrorism

$\mathrm{R} R$ - regional reasons for terrorism

$\mathrm{GR}$ - global reasons for terrorism

Source: Author's concept. 
B. Another classification concerns the subjective reasons for terrorism and can be presented in the following manner.

Figure 2: Division of reasons for terrorism due to their type (selected examples)

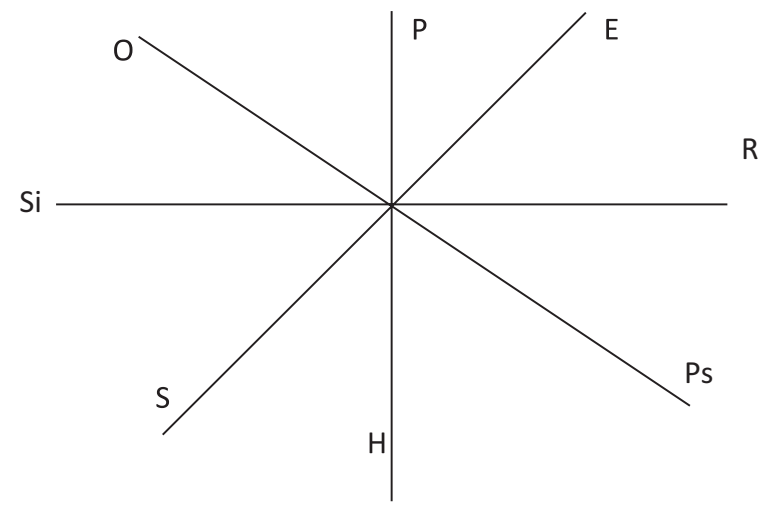

$$
\begin{aligned}
& \mathrm{P} \text { - political reasons } \\
& \mathrm{E} \text { - economic reasons } \\
& \mathrm{R} \text { - religious reasons } \\
& \mathrm{Ps} \text { - psychological reasons } \\
& \mathrm{H} \text { - historical reasons } \\
& \mathrm{S} \text { - social reasons } \\
& \mathrm{Si} \text {-single-issue reasons } \\
& \mathrm{O} \text { - other reasons }
\end{aligned}
$$

Source: Author's concept.

C. The next classification divides the reasons for terrorism due to the time of their occurrence and includes the following:

a. Timeless reasons, that is those that have accompanied the phenomenon of terrorism since its beginnings (such as religious or political conditions) - permanent reasons for terrorism.

b. Sources of terrorism that accompany it only at a certain developmental stage (over a shorter or longer period of time) - temporary reasons. They involve certain ideas or the activities that follow from these ideas (e.g. the ideology of assassins).

c. Cyclical reasons, which disappear or wane after some time, but after a shorter or longer pause they can start to play some role again, e.g. anarchism as a 
source of terrorism at the turn of the $19^{\text {th }}$ century, and again after WWII, and in the first decade of the $21^{\text {st }}$ century ${ }^{30}$.

Figure 3: Division of reasons for terrorism due to the time of their occurrence

a) Permanent reasons (PR)

b) Temporary reasons (TR)



c) Cyclical reasons (CR)

Source: Author's concept.

The fourth distinction concerns the evolution of individual reasons, which can be divided into:

a. sources of terrorism undergoing continuous change;

b. reasons undergoing occasional change;

c. factors that do not change.

The first category is illustrated by the influence of technology on terrorism. Category " $b$ " is characterized by ideological concepts, e.g. nationalism, anarchism, and so on, and their transformations, while the third one is reflected in the assumptions of anti-abortionist terrorism.

Considering these four classifications of the causes of terrorism, a relatively broad range of their manifestations or kinds can be appreciated, yet they do not account for all the possible scenarios. The theoretical character of this analysis is also a drawback, as is the less than thorough presentation of the interactions between the classifications.

30 Examples include the attacks on the embassies in Athens and Rome carried out in late 2010 and early 2011, the responsibility for which was assumed by anarchists. 
4.4. There are three main determinants that generate or escalate modern terrorism according to the hybrid of causes of terrorism:

A. Various ideas/ideologies, such as political, ethnic or religious ones, and so on that terrorists identify with, e.g. separatism, nationalism, racism, antiSemitism, chauvinism, religious fundamentalism, alterglobalism, and so on.

B. Selected socio-economic conditions. These concern a variety of socio-economic issues occurring on a large scale, such as widespread poverty, financial crises, gigantic and rapidly increasing disparities between individuals, states and between the rich and rapidly developing "North" and the significantly poorer "South." All these problems can generate or intensify various radical attitudes, including terrorism, directly or indirectly.

C. Various psychological processes and factors. They are mainly related to the issues of prejudices, stereotypes, hatred, hostility, intolerance, the sense of injustice or threat, retaliation, trauma, and so on. They very often assume the form of psychological disorders inducing e.g. suicidal attackers to commit extreme acts.

The above three elements dovetail and complement one another, entering into mutual interactions between one other and with a range of other factors. They produce a mechanism described as the so-called triad of terrorist motivation.

Figure 4: Three principal groups of reasons for terrorism (the triad of terrorist motivation)

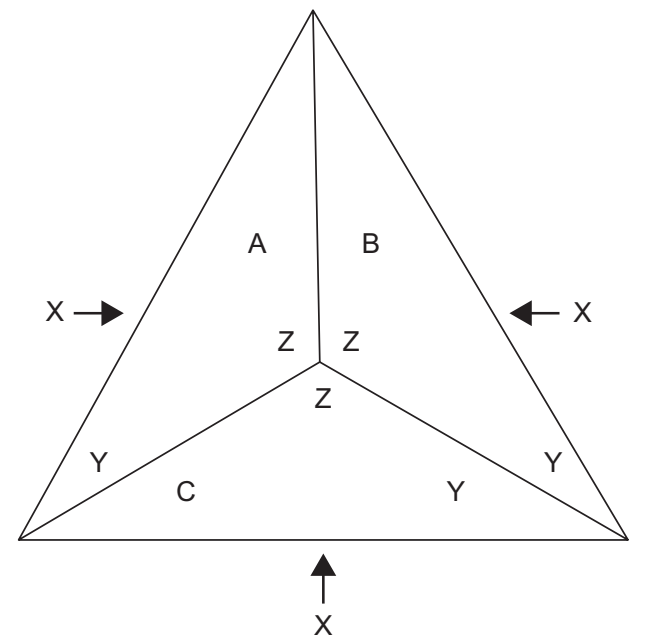

$X$ - external factors having influence upon reasons of terrorism

$Y$ - internal factors influencing reasons of terrorism

$Z$ - mutual interactions among $A, B, C$

Source: Author's concept. 
A. Various ideas/ideologies. Sources of terrorism need to be sought not only in the presence or furtherance of various, frequently highly destructive, ideas, or ideologies, but also in their mutual contradictions or confrontational character. In this context, terrorism is treated as a highly radical reflection of certain opinions, attitudes or beliefs. It is also a consequence of a conflict of interests and is frequently an attempt to achieve a certain goal 'at any cost', whatever the material damage or human toll. It can also serve the purpose of achieving certain goals or obtaining some gains, such as a change in the political situation, furtherance of specified principles or values, and so on.

The importance of ideological factors finds an excellent illustration (using the example of ETA's activity) in the statement made by G. Jackson in the article Why they kill, when he observed that acts of terror are frequently "committed by people who are not the product of suburban violence, who do not come from homes where they were mistreated by older family members or bad neighbors, who are not victims of permanent unemployment, wars of drug pushers, or racism, or religious persecutions (...). There is only one possible answer to the question 'Why do they kill?', namely: a mixture of nationalism, racism, and mystified history has become a justification for terrorism." ${ }^{31}$

B. Selected socio-economic conditions. There are numerous criteria of different kinds that can help in the analysis of the range of socio-economic problems experienced by individual states or regions. One of them involves the presentation of developmental disparities between the so-called "rich North" and "poor South." This distinction is not as much geographical as economic and geographical. It shows that approximately $14 \%$ of the global population live in "the North" in contrast to $86 \%$ living in "the South." This juxtaposition becomes particularly expressive if the above figures are accompanied by certain economic indicators, e.g. the share of global capital. The difference is very meaningful here, with "the North" and "the South" possessing $75 \%$ and $25 \%$ of global capital respectively. It should also be stressed that these two indicators (but many others as well) are not static, but dynamic. Even over quite short periods of time, they clearly change, most often to the disadvantage of the underdeveloped states. The above example shows that, on the one hand, the proportion of people living in "the North" is falling, while, on the other hand, the share of "the North" in global capital is increasing.

Another important issue that is not addressed too often is the presentation of the interdependence between the economic situation in a given territory and the emergence of terrorist attitudes. In some states we are faced with a situation where

31 G. Jackson, Dlaczego zabijają?, „Forum” no. 7, 2000, pp. 10-11. 
on the one hand they are global leaders in terms of posing a terrorist threat, while on the other they are significantly backward in terms of economic development. This is corroborated by the annual reports published by the National Consortium for the Study of Terrorism and Responses to Terrorism. The Global Terrorism Index 2015 states that "two countries, Iraq and Nigeria, account for 53 per cent of all deaths from terrorism in 2014" and "in 2014, 57 per cent of all attacks occurred in five countries; Iraq, Pakistan, Afghanistan, Nigeria and Syria." ${ }^{32}$ A definite nations and their states are in majority among the entities considered by the World Bank to be significantly backward in terms of socio-economic development.

This is not to mean that terrorism is a matter exclusively of poor states. After all, it occurs also in affluent countries, although the data show that it is not as frequent there. Obviously, socio-economic problems do not necessarily have to result in violence, terrorism and other radical attitudes, but they can be efficiently stimulated by them. ${ }^{33}$

C. Various psychological processes and factors. In many cases we encounter terrorism when a given individual or group considers a certain attitude or idea to be of the utmost importance, one which all other matters should unquestionably be subordinated to. Another significant factor is the distinction between "us" and "them," which is frequently based on the following assumptions:

- maintaining that "my" group is always the most important and the best;

- seeking the sources of the said distinction not in reality but in the subjective perception of this reality;

- admitting the necessity for antagonisms and oppositions between "my" group and the "alien" group (e.g. between the so-called West and Islam).

In the analysis of psychological factors that may influence terrorism the following should also be mentioned: a sense of "void" as regards one's worldview, a sense of injustice or oppression, hostility, post-traumatic syndrome, susceptibility to aggression, depression, and so on. It is, of course, impossible to present all the possible factors in such a brief study, nor is this its purpose. The essential purpose

32 Global Terrorism Index 2015, National Consortium for the Study of Terrorism and Responses to Terrorism, available at http://www.economicandpeace.org, accessed 15 February 2016.

33 Other socio-economic issues include: high unemployment, illiteracy, demography, famine, insufficient health care, etc. More: World Bank data; F. Llussáand, J. Tavares, Economic and Terrorism. What we Know, What we Should Know, and The Data we Need, in: Terrorism, Economic and Political Openness P. Keefer, N. Loayza (eds.), Cambridge University Press, Cambridge 2008, pp. 233-254. 
of this part of the book is to emphasize that, according to the concept of hybridity, some psychological determinants can constitute significant sources of terrorism.

Despite the multitude and diversity of the above theories, none of them comprehensively explains the emergence and escalation of terrorism. They point, however, to how numerous and different the potential factors are. These theories are frequently interdisciplinary and combine elements of psychology, as well as sociology, pedagogy, economics or philosophy.

\section{Conclusion}

It should be emphasized that the hybrid concept of reasons for terrorism (its five main assumptions) presented in the present study is not a complex model. It should be viewed as the author's attempt to analyze the complex research issue of the reasons for terrorism. Thus it is only a starting point for further considerations that may concern the following issues, among other things:

5.1. In the analysis of the sources of terrorism the mechanism of the "fuel of terrorism" is worth taking into consideration. This notion signifies the entirety of key factors that escalate terrorism. In the hybrid concept of reasons for terrorism presented in this paper these factors fall into three groups: radical ideologies and the attempts to implement them, the consequences of selected socio-economic problems, and specified destructive psychological processes. This is not to mean that the above factors fully exhaust the range of reasons for terrorism. Therefore, one may speak about the so-called complementarity of the reasons for terrorism, which means that its sources are typically varied and consist of several parallel factors.

5.2. Another interesting research issue is posed by contradictions or misconceptions concerning the reasons for terrorism. One example is the assumption that increased financial income (for example from the extraction of oil) in some states has increased social disparities and consequently intensified radical sentiments, including terrorist attitudes. ${ }^{34} \mathrm{~A}$ different example concerns the scenario in which the number of educated people and members of the middle class has rapidly increased in some Muslim countries as a result of a modernization or liberalization processes. Paradoxically, this has actually won supporters for the fundamentalists,

34 J. Esposito, Un holy War. Terror in the Name of Islam, Oxford University Press, New York 2003. 
since a part of this group supports their views..$^{35}$ In another example, unexpected situations result in terrorism. One such instance involves the attempt to detonate explosives in the USA in early 2011, which was explained by the perpetrator, who had been detained, by his dissatisfaction with the markings of local highways. A misconception regarding the sources of terrorism is illustrated by the relatively common opinion that one of the main reasons for terrorism in the European Union is religious fundamentalism. ${ }^{36}$

This, however, finds no confirmation in the detailed statistics of e.g. Europol, which point to the clear prevalence of ethnic (separatist) motives.

Table 1: Failed, foiled and completed attacks in 2014 per member state and per affiliation

\begin{tabular}{|l|c|c|c|c|c|r|}
\hline Member State & $\begin{array}{c}\text { Religiously } \\
\text { inspired }\end{array}$ & Left-wing & Not specified & Separatist & Single issue & Total \\
\hline Belgium & 1 & 0 & 0 & 0 & 0 & 1 \\
\hline France & 1 & 0 & 1 & 50 & 0 & 52 \\
\hline Greece & 0 & 6 & 1 & 0 & 0 & 7 \\
\hline Italy & 0 & 6 & 5 & 0 & 1 & 12 \\
\hline Spain & 0 & 1 & 0 & 17 & 0 & 18 \\
\hline UK & - & - & 109 & - & - & 109 \\
\hline Total & 2 & 13 & 116 & 67 & 1 & 199 \\
\hline
\end{tabular}

Source: TE-SAT 2015, EU Terrorism Situation and Trend Report, Europol, available at, www.europol. europa.eu, accessed 1 February 2016.

5.3. It is also important to perceive the reasons for terrorism in a broader perspective, that is, in terms of factors that influence also other disintegration tendencies (such as fundamentalism or separatism). A question arises here of whether there is a "repertoire" of sources common for all disintegration phenomena, or at least for the majority of them. Do individual factors (e.g. a religious or ethnic factor) influence terrorism in a different manner than fundamentalism or separatism? Are the mechanisms of their emergence similar? Is it then possible to work out a single, universal model of the reasons shaping the above trends, where certain factors will predominate depending on the situation? For example, the role of

35 R. Paz, Islamists and Anti-Americanism, "Middle East Review of International Affairs" no. $4,2003$.

36 In 2015 the number of islamic-rooted terrorist attacks in the EU rose. In previous years, their level was low, for instance: in 2012: 6, 2013: 0, $2014-2$, available at http://www. europol.europol.eu. 
ethnic factors would be larger in nationalism while the role of religious ones is more important in fundamentalism.

5.4. It is impossible to eliminate the sources of terrorism entirely. The primary objective should therefore not only be to confine them to the maximum extent possible, but also to get to know them better in order to minimize the terrorist threat. A good example is financing of terrorist organizations, which very often poses significant fundings. ISIS is the clear leader in this category, which makes this organization especially dangerous.

Table 2: Financing assets of some terrorist organizations

\begin{tabular}{|l|c|}
\hline Subject & mln \$ \\
\hline Al Qaeda & $15-50$ \\
\hline Hamas & 70 \\
\hline FARC & 300 \\
\hline Hezbollah & $200-500$ \\
\hline Taliban & 560 \\
\hline ISIS & $2000-4000$ \\
\hline
\end{tabular}

Source: International Business Times, MoneyJihad, CNN, The Guardian.

\section{References}

J. Adamski, Nowe technologie w stużbie terrorystów, Wydawnictwo Trio, Warsaw 2007.

T. Bjørg, Root Causes of Terrorism. Myths, Reality and Ways Forward, Routledge. London-New York 2005.

M. Brewer, Kryteria typologii terroryzmu, in: Encyklopedia terroryzmu, Wydawnictwo Bellona, Warsaw 2004.

D. Byman, Deadly Connections, State that Sponsor Terrorism, Cambridge University Press, Cambridge 2007.

C. Clarke, Terrorism, INC. The Financing of Terrorism, Insurgency, and Irregular Warfare, Praeger Security International, Santa Barbara 2015.

M. Crenshaw, An Organizational Approach to the Analysis of Political Terrorism, "Orbis" no. 29, 1985.

M. Crenshaw, How Terrorist Think. Psychological Contributions to Understanding Terrorism, in: Terrorism: Roots, Impact, Responses L. Howard (ed.), Praeger Westport, Connecticut, London 1992. 
M. Crenshaw, J. Pimlott (eds.), International Encyclopedia of Terrorism, Routledge, London-Chicago 1998

A. Cronin, Sources of Contemporary Terrorism in Attacking Terrorism, in: Elements of a Grand Strategy A. Cronin, J. Ludes (eds.), Georgetown University Press, Washington 2004.

J. Esposito, Unholy War. Terror in the Name of Islam, Oxford University Press, New York 2003.

E. Gellner, Nation and Nationalism, Nations and nationalism ( $2^{\text {nd }}$ ed.), Blackwell Publishing, Oxford 2006.

Global Terrorism Index 2015, National Consortium for the Study of Terrorism and Responses to Terrorism, available at http://www.economicandpeace.org, accessed 15 February 2016.

F. Gross, Violence in Politics: Terror and Political Assassination in Eastern Europe and Russia, Mouton, Hague 1972.

H. Hall (ed.), Terrorism: Strategies for Intervention, The Haworth Press, Binghamton 2002.

B. Hoffman, Inside Terrorism, Columbia University Press, London 1998.

J. Horgan, The Search for the Terrorist Personality, in: Terrorists, Victims and Society. Psychological Perspectives on Terrorism and its Consequence A. Silke (ed.), John Wiley \& Sons, London 2003.

J. Horgan, The Psychology of Terrorism, Routledge, London-New York 2005.

E. Humphrys, G. Rundle, T. Tietze (eds.), ON UTØYA: Anders Breivik, Right Terror, Racism and Europe, Elguta Press, London 2011.

S. P. Huntington, The Clash of Civilizations and the Remaking of World Order, Touchstone, New York 1997.

G. Jackson, Dlaczego zabijaja?, „Forum” no. 7, 2000.

R. Kosta, Terroryzm jako zagrożenie dla bezpieczeństwa cywilizacji zachodniej w XXI wieku, Wydawnictwo Adam Marszałek, Torun 2007.

W. Laqueur, The Age of Terrorism, Little Brown, Boston 2007.

R. Luckabaugh, J. Cangemi, C. Kowalski, Terrorist Behavior and US Foreign Policy. Who is the Enemy? Some Psychological and Political Perspectives, "Psychology" no. 34, 2007.

F. Llussáand, J. Tavares, Economic and Terrorism. What we Know, What we Should Know, and The Data we Need, in: Terrorism, Economic and Political Openness P. Keefer, N. Loayza (eds.), Cambridge University Press, Cambridge 2008.

R. Paz, Islamists and Anti-Americanism, "Middle East Review of International Affairs" no. 4, 2003. RAND Corporation and St. Andrews University in Edinburgh, available at http://www.rand.org, accessed 2 February 2016. 
R. Robins, J. Post, Paranoja polityczna. Psychopatologia nienawiści, Wydawnictwo Książka i Wiedza, Warsaw 1999.

J. Rossa, Structural Causes of Oppositional Political Terrorism, "Journal of Peace Research" 1993, no. 30.

O. Roy, Terrorism and Deculturation, in: The Roots of Terrorism. (Vol. 1 Democracy and Terrorism), L. Richardson (ed.), Routledge, New York -London 2006.

A. Schmid, A. Jongman, Political Terrorism. A New Guide to Actors, Authors, Concepts, Data Bases, Theories and Literature, Transaction Publishers, AmsterdamOxford-New York 1988.

C. Sterling, The Terror Network, The Secret War of International Terrorism, Henry Holt \& Co, New York 1981.

M. Stevens, The Unanticipated Consequences of Globalization. Contextualizing Terrorism in: The Psychology of Terrorism (Vol III. Theoretical Understandings, and Perspectives) S. Stout (ed.), Greenwood Publishing Group, Westport 2002.

A. Wejkszner, Ewolucja terroryzmu motywowanego ideologia religijna na przykładzie salafickiego ruchu dżihadu, Wydawnictwo Naukowe Wydziału Nauk Politycznych i Dziennikarstwa UAM, Poznań 2010.

P. Wilkinson, Political Terrorism, Macmillan Press, London 1974.

S. Wojciechowski, The Hybridity of Terrorism. Understanding Contemporary Terrorism, Logos Verlag, Berlin 2013. 
Pablo de Diego Ángeles and Rubén Darío Torres Kumbrián

\section{An Approach to the Economic and Financial Dimensions of Radicalization and Terrorism}

\section{Introduction: Doctrinal Approach}

An analysis of the capabilities of the European Union and its Member States regarding the fight against the financing of terrorist organizations and radical groups does not belong to the classical theoretical dilemma: European functionalism - European federalism. ${ }^{1}$

And nor can it be linked to an axiom opposing the concept of national sovereignty, despite its limitations and inadequacy to the era of globalization and new technologies. These two variables have a positive influence on the diversification and relocation of financial sources, their distribution channels and their final beneficiaries: radical and terrorist organizations who preach and practice the ideologies of hatred.

Empirical evidence suggests that the discourse and practice of national sovereignty, together with an uncompromising zeal of the European governments, create considerable barriers in the design of a comprehensive European policy regarding the eradication of the sources and circuits of funding of radical and terrorist movements.

Our analytical approach relies on verifiable evidence. The weaknesses affecting the capabilities of the European Union in this field also affect many other political scenarios that are closely connected to the internal and external security of the European Union. In this regard, we can argue that more noticeable and important evidence of the weaknesses affecting the intervention capabilities of the European Union are the Syrian refugee crisis and immigration. ${ }^{2}$

1 F. Aldecoa, Unión Europea: del funcionalismo al modelo federal en el siglo XXI, available at http://www.uimp.es/blogs/la-linea/actividades/cronicas-ue/\%E2\%80\%9Cunioneuropea-del-funcionalismo-al-modelo-federal-en-el-siglo-xxi\%E2\%80\%9D/, accesed 8 January 2016.

2 Persecution, conflict and poverty have driven a staggering one million people to seek safety in Europe in 2015, according to estimates by the UN Refugee Agency, UNHCR and the International Organization for Migration, IOM, available at http://www.unhcr. org/5679451d6.html, accessed 19 January 2016. 
This crisis could be one of the financial sources of the Daesh and other criminal organizations, as well as a strategic and operational resource of military and political nature that could facilitate the undercover infiltration of terrorists, weapons and explosives in the flow of refugees and immigrants heading to Europe.

The axiomatic approach, which we employ in order to analyze the capabilities of the European Union, with a reference to Spain, falls within the vision that Francisco Aldecoa, ${ }^{3}$ Professor at the Complutense University of Madrid, called $a$ process of intergovernmental federalism, which started with the Laeken Declaration of 2001 and is currently supported by the Treaty of Lisbon.

We believe that intergovernmental federalism can be defined as a mechanism of adaptation of the national sovereignty to the demands imposed by globalization and the impact of the new technologies in the strategies and effectiveness of radical and terrorist organizations along with their sources of funding, circuits for the distribution of resources, intermediaries, direct and indirect beneficiaries, and final recipients of the financed resources.

The aforementioned adaptive process recognizes the validity of the State as a leading player in the internal and external security policy, while allowing the European Union to expand and strengthen its capabilities in this field.

In conclusion, the approach of the European Commission aims to overcome the current limitations of the intervention capabilities of the European Union and its Member States. Against this backdrop, it is appropriate to express the following hypothesis, which is, to a considerable degree, a reasonable one: all national policies dissenting from the positions adopted by the European Commission are bound to be ineffective.

\section{Axiomatic Premises for the Analysis of the Economic and Financial Connections Between Radical, Terrorist and Criminal Organizations}

The economic and financial links between organized crime, radical movements and terrorism are no novelty, nor they are an innovation. These economic, financial, social and political interrelationships are a historical tradition, even within governments. The purpose is to establish, by means of terror, a state of impunity and to prevail over the State and the rule of law. However, radicalism, terrorism and organized crime are not concepts with the same meaning.

3 F. Aldecoa, Unión europea...op.cit. 
Radical and criminal organizations do not necessarily have to be terrorist organizations. Not all terrorist organizations are engaged in typical activities of the organized crime, and not all radical organizations perform activities typical of the organized crime and terrorism. However, the coincidence or convergence of common interests and purposes determines an organization to widen its range of action so as to perform simultaneous types of activities, of organized crime, radical or terrorist nature. This phenomenon has been addressed by both the Convention of Palermo ${ }^{4}$ and the Convention of Vienna ${ }^{5}$ According to the classification made by the investigator Edgardo Buscaglia, ${ }^{6}$ we can analyze the connections between organized crime and terrorist organizations and proceed to making the following distinctions: ${ }^{7}$

Organized crime groups unrelated to terrorism.

Organized crime groups engaged in terrorist activities such as the Medellín cartel or the Italian Mafia, which turned to terrorism in the pursuit of impunity. Terrorist groups that engage in criminal activities to finance their deviant political purposes.

Terrorist groups that exchange goods with the organized crime.

Terrorist organizations funded by other means than those of crime.

\section{Axiomatic Premises for the Analysis of the Political Players}

Three roles that represent the positions of the European Union Member States governments can be identified. The bipolarity is represented by Chancellor Angela Merkel, and her proposal of giving a European solution to an international problem is ignored by the members of the European Council. At the other end,

4 United Nations, Convention Against Transnational Organized Crime and the Protocols Thereto, 2004, available at https://www.unodc.org/documents/middleeastandnorthafrica/organisedcrime/UNITED NATIONS_CONVENTION_AGAINST TRANSNATIONAL_ORGANIZED_CRIME_AND_THE_PROTOCOLS_THERETO.pdf, accessed 9 January 2016.

5 United Nations, Vienna Convention on the law and teatries, 1980, available at https:// treaties.un.org/doc/Publication/UNTS/Volume\%201155/volume-1155-I-18232-English.pdf, accessed 9 January 2016.

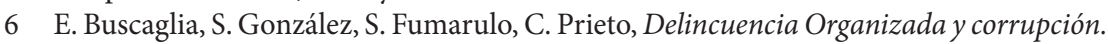
Delincuencia organizada y terrorismo. Su combate a través de la Convención de Palermo, 2004, available at https://www.unifr.ch/ddp1/derechopenal/temas/t_20080528_83.pdf, accessed 9 January 2016.

7 Ibid. 
the Hungarian President Viktor Orbán is an icon of the new isolationist populism, characterized by applying reductionism and biased measures as long as they contradict neither the original ${ }^{8}$ nor the secondary acquis communautaire, nor the International Law subscribed to by Hungary.

Between these two extremes, one can identify a variety of government positions characterized by ambiguity and a political discourse articulated in the rhetoric of correction and lacking a material engagement consistent with the magnitude of the problem.

The result of all these contradictions has been the following: the Schengen area ${ }^{9}$ is considerably affected and this is not unrelated to the anti-terrorism policies, not even in the field of funding of these organized crime groups.

Community politics and state policies dealing with the eradication of the funding of radical movements and organizations are still in time to avoid the damage suffered by Schengen. The risks are important, since the economic structures, sources of funding, money laundering networks and distribution channels of the financial resources are the backbone of criminal organizations, also of those defined as radicals and terrorists.

In fact, the distinction between criminal, terrorist and radical organizations leads to confusing interpretations, since these three signifiers have an unmistakable meaning, which in some cases, such as the Daesh and the groups that fall into its range of influence, is: organized crime, internationalization and diversification of illicit economic activity and ideology of hatred.

This is an economy based on a clear expression of the ideology of hatred. The difference between the Daesh and other criminal organizations lies in their disguise as a theocratic State. The resemblance between this terrorist organization and other criminal organizations is the pursuit of profit and financial resources destined to the privileged figures of its oligarchy and to guarantee the loyalty of their followers and the consolidation and expansion of the organization. All this justified in the name of a distorted interpretation of an invented, caricatured Islam. This Islam preached by the Daesh never existed in the historical ${ }^{10}$ and

8 The Orbán Effect: EU Conservatives Have a Hungary Problem, "Spiegel”, 2013, available at http://www.spiegel.de/international/europe/hungarian-government-puts-europeanconservatives-in-tough-spot-a-902620.html, accessed 7 January 2016.

9 The Schengen area and cooperation are founded on the Schengen Agreement of 1985. The Schengen area represents a territory where the free movement of persons is guaranteed.

10 G. Kepel, La yihad: expansión y declive del islamismo, Peninsula, Barcelona 2001. 
social $^{11}$ reality. The Daesh version is the extreme, and hence deformed, version of the Saudi Wahhabism, an Islamic movement that emerged in the last third of the nineteenth century in the Arabian peninsula. ${ }^{12}$

\section{Actions Taken by the European Union and Its Member States}

The economic and financial aspects outline a key scenario of the fight against terrorism. ${ }^{13}$ The European Union is supporting new measures for the fight against terrorist organizations. ${ }^{14}$

The European Commission developed a package of measures to be analyzed by the Council of Ministers of Economy and Finance of the EU of January 2016. However, the Community decision-making method is slow, even in those sectors which benefit from a reinforced cooperation, and especially in those stages in which the European measures have to be extrapolated to the national laws of its Member States.

Following the attacks that took place in Paris in November 2015, twenty-eight Member States of the EU made substantial progress in areas related to the rate of financial transactions, the Banking Union, tax arrangements and other instruments for combating tax base erosion. Another European priority is to achieve a quick extrapolation of the fourth directive of combat against money laundering ${ }^{15}$ and of the regulations regarding the information that should be included in the transfers of funds.

11 R. Torres, L. Ponce de León, Reislamización digital y yihadismo europeo: claves comprensivas para la intervención social comunitaria, "Sistema", no. 240, 2015, pp. 101-116.

12 G. Kepel, Jihad: The Trail of Political Islam, Harvard University Press, Cambridge 2003.

13 FATF Financial Action Task Force, Recommendations are recognised as the global anti-money laundering (AML) and counter-terrorist financing (CFT) standard, 2012, available at http://www.fatf-gafi.org/media/fatf/documents/recommendations/pdfs/ FATF_Recommendations.pdf, accessed 17 January 2016.

14 European Commission, Commission takes steps to strengthen EU cooperation in the fight against terrorism, organised crime and cybercrime, available at http://europa.eu/rapid/ press-release_IP-15-4865_en.htm, accessed 17 January 2016.

15 Directive 2015/849 of the European Parliament and of the Council of 20 May 2015 on Prevention of the use of the financial system for the purposes of money laundering or terrorist financing, amending Regulation, available at http://eur-lex.europa.eu/legalcontent/EN/TXT/PDF/?uri=OJ:L:2015:141:FULL\&from=EN, accessed 7 December 2015. 
However, the meaning of the concept of acceleration in the European decision-making processes depends on the legislative decisions taken by national governments and parliaments, and thus the planned package of measures could be implemented in June 2017. This period of time is too long to deal with a contingency that requires the suppression of the sources of funding of terrorist organizations.

The weaknesses in the European Union's capabilities come from state resistances whose ideological foundation is based on a concept of national sovereignty which is prior to the phenomenon of globalization, and therefore ineffective in taking action in due time at a European and global scale: Here and now.

The alternative monetary circuit through which the electronic money flows, virtual currencies and prepaid cards are evidence showing the European weaknesses. The lack of legal, institutional and administrative European tools is obviously hindering the intervention in a sector which is, in itself, refractory and evasive to all kinds of public intervention, both at the state and global levels.

The problems experienced by the European Union come from state actors, who respond to global issues, especially to those regarding the financial world, under the cloak of an anachronistic ideology of national sovereignty, and who are reluctant to go beyond and overcome the limited coordination mechanisms existing between the states and agencies. The financial sector is ungraspable due to several reasons, including an opacity that helps promoting the financial sources and channels of distribution of radical and terrorist organizations. ${ }^{16}$

The Daesh and global jihadism are consequences of a phenomenon that is not new, and that has challenged the internal and external security of the European Union and its Member States. Its origins date back to the attacks of 9/11 and of 1973, when the oil crisis helped multiplying the revenues of Saudi treasuries, and when an unprecedented expansion of the Wahhabism took place. The latter is a hermeneutic movement of the Islam that has no roots in the schools and movements of this religion, and is imprisoned by an out of the context, hermeneutic literality and other demands which are inevitable for the Muslims themselves, such as the role model represented by Muhammad, the first Umma and the Quran. However, the oil revenues helped the worldwide expansion of the Wahhabism.

16 United Nations, International Convention for the Suppression of the Financing of Terrorism, 1999, available at http://www.un.org/law/cod/finterr.htm, accesses 19 December 2015. 
The Treaty of Amsterdam, which came into force on May, $1^{\text {st }} 1999$, is a major legal instrument of the European Union in the fight against organized crime. ${ }^{17}$ The Framework Decision expressed by the Council of the European Union one week after the events of 9/11 and Directive 97 of December 2001 regarding the restriction of the use of the financial system for the purpose of money laundering, were strong milestones in the European anti-terrorism policy.

Other important achievements include rules set by the Council by which customized restrictive measures directed against certain persons and entities have been established, with the aim of fighting against terrorism. The initiatives were completed in December 2001, when the European Commission commenced to publish a list of terrorists and terrorist groups.

By acknowledging this positive development, we must stress that the internal and external security of the European Union $^{18}$ represents the security of its Member States and their citizens. This is an urgent matter and we cannot wait until 2017 for the implementation of a European mechanism of freezing of assets, and for the application of other measures regarding the fight against the illegal trade of cultural goods; control of prepaid cards; creation of centralized national registers of bank accounts in each Member State, etc.

The European weaknesses in this area can be observed from a comparative perspective. The United States has the SWIFT system, ${ }^{19}$ while in the EU the implementation of a European Monitoring System of the Financing of Terrorism is still a pending issue.

\section{France and Spain as References}

For the aforementioned reasons, it is necessary to focus our attention on the instruments employed by some of the Member States of the EU, as well as on their current actions regarding the war against terrorism in the financial field.

17 Treaty of Amsterdam, at http://europa.eu.int/eur-lex/es/search/search_treaties.html, accessed 4 December 2015.

18 European Commision, Proposal Council Regulation on specific restrictive measures directed against certain persons and entities with a view to combating international terrorism, 2002, available at http://www.law.kuleuven.be/iir/nl/onderwijs/terrorisme/ COM2001e713.pdf, accessed 3 December 2015.

19 Bank Codes, SWIFT or BIC, Codes that identifies financial and non-financial institutions and is mainly used for international wire transfers between Banks, available at http://www.bank-codes.com/country/united-states-usa\#ixzz43NtZ51xS, accessed 4 January 2016. 
The attacks that took place in Paris in November 2015 seem to have revived the French leadership, as suggested by the initiatives regarding the strengthening of the powers of the Financial Intelligence Units ${ }^{20}$ in order to ease the access to bank details, without the need for a prior report on a potentially suspicious transaction. France also calls for improvement in the mechanisms for the exchange of information.

State legal constraints are not the same in all Member States of the EU. In the case of Spain, the Sepblac intelligence service, can undertake operations of greater scope and depth than the corresponding agencies of other Member States of the EU. Therefore, it can be argued that the development and improvements made in the Spanish regulatory framework have reached a satisfactory level in comparison to the limitations experienced by other Member States of the European Union.

The Spanish legislative acquis is faithful to the international and European lines of thought, ${ }^{21}$ while also being affected by the weaknesses in the capabilities of the EU in this field.

The positive evolution of the Spanish legislation is confirmed by its current state of development, supported by the validity of the Royal Decree 304/2014 of May $5^{\text {th }}$, by which the Law 10/2010 of April $28^{\text {th }}$ on the prevention of money laundering and terrorist financing, is approved (BOE 05/05/14). Its legislative starting point is represented by the Law $19 / 1993$ of December $28^{\text {th }}$, which includes certain measures for the prevention of money laundering (BOE 29/12/93).

The Spanish legislative journey is based on an extrapolation of the Directives 2006/70/EC ${ }^{22}$ and 2005/60/EC of the European Parliament and the Council of October $26^{\text {th }}, 2005,{ }^{23}$ and is consistent with the theoretical provisions of these

20 UK-Parliament, Money laundering and the financing of terrorism, 2008, available at http://www.publications.parliament.uk/pa/ld200809/ldselect/ldeucom/132/132ii.pdf, accessed 9 January 2016.

21 Royal Decree 304/2014 of My $5^{\text {th }}, 2014$, approving the regulation developing the Law 10/2010 of April 28 ${ }^{\text {th }}, 2010$ on the prevention of money laundering and terrorism financing, Official State Bulletin 110, 06.05.2014, pp. 34775.

22 European Commission. COMMISSION DIRECTIVE 2006/70/EC of 1 August 2006 laying down implementing measures for Directive 2005/60/EC of the European Parliament and of the Council as regards the definition of 'politically exposed personand the technical criteria for simplified customer due diligence procedures and for exemption on grounds of a financial activity conducted on an occasional or very limited basis, 2006, available at http://eur-lex.europa.eu/legal-content/EN/TXT/HTML/?uri=CELEX:320 06L0070\&from=ES, accessed 9 December 2015.

23 Directive 2005/60/EC of the European Parliament and of the Council of October $26^{\text {th }}$, 2005 on the prevention of the use of the financial system for the purpose of money 
European standards and of other similar standards included in the acquis communautaire.

The current legislation, under development by the European Union, includes the obligations, actions and procedures necessary to prevent and impede the use of the financial system and other areas of economic activity for the purpose of money laundering and financing of radical and terrorists groups and organizations. However, these capabilities and the available instruments of public intervention have to be adjusted to the real scale of jihadist funding, which is characterized by diversification and effectiveness.

\section{The Global Economy of Terror and Its Underlying Causes}

Contraband oil; the trafficking in arms, antiques, and human beings; taxes; the forgery of documents; donations; the trade in agricultural products; toll charges; kidnappings and slavery - these form the structure of the global economy of terror. The Daesh aspires to be a State, and acts as a State in Iraq and Syria, where Baghdad and Damascus are unable to impose their authority. ${ }^{24}$

International actors have contributed irregularly to this unprecedented scenario, ${ }^{25}$ and thus the hypothesis laid out by researcher Noam Chomsky in his book 9-11: Was There An Alternative? seems to be confirmed: current empirical evidence suggests a partial but significant revision of the geopolitical strategies of regional and international political actors, mainly because the list of theaters of terror has expanded from the Middle East to the Western European cities, and to other cities all over on the planet.

The current war against terrorism and the public interventions against radicalization are defined by relocation, a feature that can also be observed in the field of funding of these criminal organizations and of other radical organizations operating at the borderline of what is legally and politically acceptable.

laundering and terrorist financing, at http://eur-lex.europa.eu/legal-content/EN/TXT/ HTML/?uri=URISERV:124016a\&from=ES, accessed 12 December 2015.

24 L. Napoleoni, El fénix islamista. El Estado Islámico y el rediseño de Oriente Próximo, Editorial Paidós, Barcelona 2011.

25 N. Chomsky, Once de Septiembre, RBA, Barcelona 2011. 


\section{The Financial Flows of Radicalism. Report of the National Intelligence Centre (CNI). Spain}

Financial flows also support activities related to radicalism, which is considered to be the precursor of terrorism. The $\mathrm{CNI}^{26}$ warns, according to the El País newspaper $^{27}$ which refers to secret CNI reports, that there are six Muslim countries that support Islam. ${ }^{28} \mathrm{~A}$ report of the CNI points out that these donations arrive in the hands of radical organizations. This document of the Spanish CNI ${ }^{29}$ declares according to the aforementioned source, that six Arab-Muslim countries are supporting the Islamic communities in Spain. Among the purposes of these donations is the aim to gain control of them, usually with little discernment.

This report of the National Intelligence Centre (CNI) provides an analysis of the funding and support offered by Saudi Arabia, Kuwait, Qatar, United Arab Emirates (EAU), Libya and Morocco to the Muslims in Spain.

The verdict of the CNI identifies a tendency that affects other countries of the European Union as well: there is insufficient control of she financial flows generated by the donations and financial aid that other countries send to the Islamic community in Spain, and a lack of attention to the risks of financing individual needs.

The aim of the Spanish government is to make the oil monarchies support only the projects presented by the Muslim communities to the Islamic Commission of Spain (CIE), the official interlocutor, which is currently undergoing developments in order to be more representative. Only applications approved by the CIE would have the chance to be financed by grantors.

According to the report of the Spanish Intelligence Service, Kuwait is the country that, by means of the Society of the Revival of Islamic Heritage (RIHS), paid for the construction of the Torredembarra and Reus mosques in Catalonia, where a religious interpretation discouraging the integration into Spanish society and supporting the separation and hatred toward non-Muslim groups is preached.

The Kuwaiti RIHS was included in 2008 by the Treasury Department of the USA, and later by the United Nations, in the list of organizations that finance the Al Qaeda-affiliated groups. The main beneficiary of their aid and an administrator

26 I. Cembrero, El CNI alerta de que seis paises musulmanes financian al islamismo, "El PAIS" 31.07.2011, available at http://politica.elpais.com/politica/2011/07/31/actualidad/1312140952_655494.html, accessed 19 January 2016.

27 Ibid.

28 Ibid.

29 Ibid. 
of Saudi money in Spain could be, according to the Secret Service, the Dutch Salafist of Moroccan origin Abdelhamid el Hyat. On the mid term, the RIHS intends to open a local office in Spain.

Qatar seems to donate preferentially to the Islamic League for Dialogue and Coexistence in Spain, which is linked to the Muslim Brotherhood in Syria, according to the CNI, and which controls, for example, the Catalan Islamic Cultural Centre.

In contrast, Sharjah, one of the United Arab Emirates, has a preference for the Spanish converts gathered in Al Morabitun, whom it paid for the construction of the Albaicín mosque of Granada, and is willing to offer support for another mosque in Seville.

The Spanish secret services have reported some isolated financing actions, such as the 300.000 euro paid by Qatar to remodel the Catalan Islamic Cultural Center. However, it is common to use alternative channels in order to deliver such donations that go beyond the control of the authorities of the Spanish financial system.

Saudi Arabia is the most important net contributor. In addition to the direct donations made by the royal family, we can consider those made by its Embassy in Madrid and by a large number of not entirely official charitable associations. However, it is worth mentioning that the mosques and centers that benefit from the Saudi funding are not defined by their high level of radicalism, according to the CNI, despite the fact that they are totally submitted to the Saudi directives.

The CNI report warns that among the recipients of these donations are also individual actors who grant themselves with an improper representation. The Spanish intelligence service notes that some of the trips to the Arabian Peninsula for collecting subsidies are carried out in the utmost secrecy and without the knowledge of the Islamic community in the name of which they are requested. If the financial resources are obtained, they do not always serve the official purpose for which they were requested. ${ }^{30}$

\section{Donors}

Private wealthy donors and Islamic charitable organizations in the Middle East particularly of Saudi Arabia and Qatar - were the initial source of income. Donors have sought to overthrow Syrian President Bashar al Assad, who belongs to the Islamic Alawite sect. A part of these donations covered the transportation of foreign fighters to Syria and Iraq. Currently, the Daesh has reached significant levels of self-financing. 


\section{Oil}

The Treasury Department of the United States estimates that in 2014 the Daesh could have won up to several million dollars per week, adding up to a USD 100 million in total from the sales of crude oil and refined products. The products were sold to local retailers, who in turn smuggled the goods in Turkey and Iran, or sold them to the Syrian government. The Daesh does not want to destroy the energy sources obtained by military conquest. ${ }^{31}$ Their aim is to use the earnings for the construction of the Islamic State or Caliphate.

Theodore Karasik, of the INEGMA centre (Dubai) and Robin Mills, author of the book The Myth of the Oil Crisis, estimate that the Daesh spends USD 1 billion per day on the exploitation of Iraqi oil.

Researchers argue that by adding the benefits in Iraq and Syria they could reach the figure of USD 100 billion per month. Before the falling in the price of oil, the Daesh sold a barrel for USD 30 through the retailers in Turkey and Syria who introduced them on the black market.

In the case of Syria, a study ${ }^{32}$ carried out at the Analysis Centre of the European Council on Foreign Relations (ECFR) shows that while the military component is unavoidable in the fight against the Daesh, it will not be successful so long as it is not included within a more complex strategy. A late inclusive diplomacy should be the immediate priority of the European governments. An approach that overemphasizes military action will let a great opportunity pass by and will run the risk of doing more harm than good.

\section{Kidnapping, robbery, looting, extortion}

Kidnapping was the source of at least USD 20 billion in ransom payments in 2014. Foreign journalists risk to be kidnapped the moment they set foot in cities close to the border with Syria. Kidnapping is a financial resource and, to a greater extent, a valuable tool of propaganda.

The Daesh wins several million dollars a month from the extortion of those living in the areas found under their total or partial control. These financial resources come from toll payments for using transportation channels; for allowing commercial activity and the belonging to other religions; for offering a protection

31 M. Aguirre, ¿Cómo se financia el Estado Islámico?, BBC, El Mundo, 14.08.2014, available at http://www.bbc.com/mundo/noticias/2014/08/140825_estado_islamico_como_se_ financia_ch, accessed 20 December 2015.

32 J. Barnes, D. Levy, S. Diplomacy, From Vienna to Raqqa, ECFR, 27.11.2015, available at http://www.ecfr.eu/madrid/publi/de_viena_a_raqqa_necesidad_de_una_diplomacia_inclusiva_en_siria, accessed 3 December 2015. 
service to the residents and neighbors of a town. They also come from bank attacks, looting, trafficking and sale of antiques; from theft; from the control over the sales of livestock and crops; and from slavery.

\section{Taxation on the right to exist of other religions, kidnapping, sexual exploitation, trafficking in human beings and slavery}

The Daesh forces religious minorities to pay a special tax, called jizya. Last year, a statement was announced in the mosques of the Iraqi city of Mosul, calling on Christians to either convert to Islam, pay the jizya or face death unless they left the city. The sale of girls and women kidnapped in order to be turned into sex slaves appears to be a common situation.

In the town of Sinjar of northern Iraq, the Yazidi religious minority reported that thousands of their women and little girls were captured and that many were used as sex slaves. Kidnapping is a business that relies on spies, informants, kidnappers, guards and negotiators who reach agreements to free some of the hostages. ${ }^{33}$

The investigation suggests that the Daesh and other armed groups are implementing a tax system in the areas they conquer, while promoting illegal activities such as stealing the financial reserves of provincial banks, cars and weapons smuggling, kidnappings and roadside checks.

\section{Conclusion}

The European Union is a major actor in the global Strategy of the United Nations against terrorism. ${ }^{34}$ The aforementioned strategy relies on a working Group to examine the various components of the measures taken to prevent the financing of terrorism and submit proposals aimed at increasing the effectiveness of the implementation of international rules, including the special Recommendations on terrorist financing made by the Financial Action Task Force (FATF-GAFI).

In October 2009, the FATF issued a Report that included 35 findings and 45 recommendations aimed to assist Member States of the EU in increasing the effectiveness of their measures of combat against the financing of terrorism.

33 J. Bartlett, En la millonaria máquina de secuestrar de Estado Islámico, BBC, El Mundo, 15.09.2015, available at http://www.bbc.com/mundo/noticias/2015/09/150922_testimonio_secuestros_estado_islamico_lav, accesed 25 Septiember 2015.

34 United Nations, Guia legislativa del régimen jurídico universal contra el terrorismo, 2008, available at https://www.unodc.org/documents/terrorism/Publications/Legislative_Guide_Universal_Legal_Regime/Spanish.pdf, accessed 18 October 2015. 
Five topics were addressed:

classification as a crime of terrorist financing;

strengthening national and international cooperation;

value transfer systems;

non-profit organizations;

and freezing of assets.

Based on the findings and recommendations of this Report, the International Monetary Fund (IMF) drafted an Action Plan with proposals for the implementation of these recommendations, to be considered by the members of the Financial Action Task Force. Most of the entities that took part in the Financial Action Task Force have already integrated parts of these recommendations into their own work programs. After an examination of their findings and recommendations carried out by multidisciplinary experts, the FATF completed their Report in October 2009. The Report includes 36 findings and 45 recommendations aimed to assist the Member States of the EU in increasing the effectiveness of their measures of combat against terrorist financing.

The global Strategy of the United Nations against terrorism, ${ }^{35}$ adopted by the General Assembly on the $8^{\text {th }}$ of September 2006, serves as a common platform, putting together the efforts of the entities of the United Nations that address issues related to the fight against terrorism in a common, coherent and more precise framework. There are different activities that can be categorized as transnational organized crime, such as drug trafficking, smuggling of migrants, trafficking in human beings, money laundering, trafficking in arms, counterfeiting, crimes against the environment, crimes against intellectual property and heritage, and even some aspects of the so-called cybercrime.

Monitoring the flow of money not only helps preventing the attacks but can also provide useful information for further investigations. The Member States of the EU are also members of the United Nations Convention against Transnational Organized Crime.

It is also worth mentioning The International Convention for the Suppression of the Financing of Terrorism - on April 23 ${ }^{\text {rd }}, 2006$, the Convention had the support of 153 State Parties. This means an increase of 149 states since the attacks of

35 United Nations, The Globalization of Crime: A Transnational Organized Crime Threat Assessment, 2010. available at https://www.unodc.org/documents/data-and-analysis/ tocta/TOCTA_Report_2010_low_res.pdf, accessed 19 December 2015. 
the 9/11, although 38 Member States of the UN still has not joined the Convention until recently.

The European Union encouraged the financial sanctions regime of the United Nations. This is an important instrument for ensuring the effectiveness of the measures against the financing of terrorism. The Member States of the EU are developing their acquis under this international trend, approved by the European legal framework.

In 1998, there were less than 20 terrorist websites. Experts estimate that in 2015 the figure exceeded several thousand. In fact, it seems that some of the major attacks were based on information obtained by means of the Internet.

The EU slowly reinforces its border controls, especially in developing countries. The World Bank supported the reform and modernization of border management systems, facilities and institutions at the national, regional and international levels.

The Member States of the European Union have encouraged the international community to adopt a series of important measures aimed at providing a solid legal basis for common actions of combat against the promotion of terrorism, especially through the ratification of 13 universal instruments related to the prevention and suppression of international terrorism, as well as the Security Council resolutions 1267 (1999), 1373 (2001), 1540 (2004), 1566 (2004) and 1624 (2005).

In order to strengthen the authority of the Security Council and its role in this field, the Council bodies dealing with terrorism will need to develop standards of compliance and accountability and use them to evaluate the work of individual States in order to differentiate between States that are considered able but unwilling to fulfill their obligations and States that lack the capacity to do so.

The internal and external security of the EU seems to develop the required capabilities in all required fields, even though this effort is neither consistent nor synchronic with the scale of the problem of financing the global economy of terrorism, radicalization, and organized crime.

Various organizations of the United Nations and its partners, especially the International Monetary Fund (IMF), the World Bank, the United Nations Office on Drugs and Crime, and the Interpol are working in order ensure the States have the necessary laws and institutions to fully comply with the international standards and obligations regarding the fight against money laundering and financing of terrorism. The European acquis, together with its instruments and intervention capabilities, are an essential reference for the international community.

The cost estimate needed to fight threats posed by terrorist organizations like the Daesh is high and difficult to break down. It is estimated that in 2014 the global economic costs of terrorism reached 52.900 billion USD (49.000 billion EUR), 
and a total economic impact of 105.800 billion USD. These figures have been calculated using the IEP methodology of the economic cost of violence, ${ }^{36}$ which measures the direct and indirect costs generated by the loss of life, destruction of property and ransom payments.

The quantification of the total global economic costs of terrorism is complicated. Direct costs include direct loss of life and damage to property caused by a terrorist attack. The estimation of indirect costs is less tangible and precise.

The direct global costs of terrorism added up to a total of 52.900 billion USD in 2014 . This means an increase of $61 \%$ over the previous year's total, which was of 32.900 billion USD; this figure that has multiplied by more than 10 since 2000 . The vast majority of these costs arise from injury and death.

Since 2000, there has been a growing trend toward smaller-scale bombings and explosions, and a decrease in large-scale attacks against property, which cause damage worth more than one billion dollars. Losses caused by terrorism added up to 52.900 billion USD in 2014, as opposed to 1.7 trillion USD lost as a result of violent crimes and homicides.

\section{References}

F. Aldecoa, Unión Europea: del funcionalismo al modelo federal en el siglo XXI, available at http://www.uimp.es/blogs/la-linea/actividades/cronicas-ue/\%E2\%80\%9Cunion-europea-del-funcionalismo-al-modelo-federal-en-el-siglo-xxi\%E2\%80\%9D/, accesed 8 January 2016.

M. Aguirre, ¿Cómo se financia el Estado Islámico?, BBC, El Mundo, 14.08.2014, available at http://www.bbc.com/mundo/noticias/2014/08/140825_estado_ islamico_como_se_financia_ch, accessed 20 December 2015.

Bank Codes, SWIFT or BIC, Codes that identifies financial and non-financial institutions and is mainly used for international wire transfers between Banks, available at http://www.bank-codes.com/country/united-states-usa\#ixzz43NtZ51xS, accessed 4 January 2016.

J. Bartlett, En la millonaria máquina de secuestrar de Estado Islámico, BBC, El Mundo, 15.09.2015, available at http://www.bbc.com/mundo/noticias/2015/09/150922_ testimonio_secuestros_estado_islamico_lav, accesed 25 Septiember 2015.

36 Institute for Economic and Peace, A Comprehensive Assessment of the Global Cost of Violence, available at http://economicsandpeace.org/wp-content/uploads/2015/06/ The-Economic-Cost-of-violenceContainment.pdf, accessed 12 December 2015. 
J. Barnes, D. Levy, S. Diplomacy, From Vienna to Raqqa, ECFR, 27.11.2015, available at http://www.ecfr.eu/madrid/publi/de_viena_a_raqqa_necesidad_de_ una_diplomacia_inclusiva_en_siria, accessed 3 December 2015.

I. Cembrero, El CNI alerta de que seis países musulmanes financian al islamismo, "El País", 31.07.2011, available at http://politica.elpais.com/politica/2011/07/31/ actualidad/1312140952_655494.html, accessed 19 January 2016.

N. Chomsky, Once de Septiembre, RBA, Barcelona 2011.

E. Buscaglia, S. González, S. Fumarulo, C. Prieto, Delincuencia Organizada y corrupción. Delincuencia organizada y terrorismo. Su combate a través de la Convención de Palermo, available at https://www.unifr.ch/ddp1/derechopenal/ temas/t_20080528_83.pdf, accessed 9 January 2016.

Directive 2015/849 of the European Parliament and of the Council of 20 May 2015 on Prevention of the use of the financial system for the purposes of money laundering or terrorist financing, amending Regulation, available at http://eur-lex. europa.eu/legal-content/EN/TXT/PDF/?uri=OJ:L:2015:141:FULL\&from=EN, accessed 7 December 2015.

Directive 2005/60/EC of the European Parliament and of the Council of 26 October 2005 on the prevention of the use of the financial system for the purpose of money laundering and terrorist financing, available at http://eur-lex.europa.eu/ legal-content/EN/TXT/HTML/?uri=URISERV:124016a\&from=ES, accessed 12 December 2015.

European Commision, Proposal Council Regulation on specific restrictive measures directed against certain persons and entities with a view to combating international terrorism, 2001, available at http://www.law.kuleuven.be/iir/nl/onderwijs/terrorisme/COM2001e713.pdf, accessed 3 December 2015.

European Commission, Commission takes steps to strengthen EU cooperation in the fight against terrorism, organised crime and cybercrime, 2015, available at http:// europa.eu/rapid/press-release_IP-15-4865_en.htm, accessed 17 January 2016.

FATF Financial Action Task Force, Recommendations are recognised as the global anti-money laundering (AML) and counter-terrorist financing (CFT) standard, 2012, available at http://www.fatfgafi.org/media/fatf/documents/recommendations/pdfs/FATF_Recommendations.pdf, accessed 17 January 2016.

Institute for Economic and Peace, A Comprehensive Assesment of the Global Cost of Violence, 2015, available at http://economicsandpeace.org/wp-content/uploads/2015/06/The-Economic-Cost-of-violenceContainment.pdf, accessed 12 December 2015.

G. Kepel, La yihad: expansión y declive del islamismo, Peninsula, Barcelona 2001.

G. Kepel, Jihad: The Trail of Political Islam, Harvard University Press, Cambridge, 2003. 
L. Napoleoni, El fénix islamista. El Estado Islámico y el rediseño de Oriente Próximo, Editorial Paidós, Barcelona 2011.

Comisión de Prevención de Blanqueo de Capitales e Infracciones Monetarias, Order EHA/114/2008 of the $29^{\text {th }}$ of January 2008, regulating certain obligations of notaries in the field of prevention of money laundering, 2008. at http:// www.sepblac.es/espanol/legislacion/prevbcap/fichas/eha114_08.htm, accessed 29 November 2015.

Persecution, conflict and poverty have driven a staggering one million people to seek safety in Europe in 2015, according to estimates by the UN Refugee Agency, UNHCR and the International Organization for Migration, IOM, available at http://www.unhcr.org/5679451d6.html, accessed 19 January 2016.

Royal Decree 304/2014 of 5 May 2014, approving the regulation developing Law 10/2010, of 28 April 2010, on prevention of money laundering and terrorism financing, Official State Bulletin 110, 06.05.2014, pp. 34775.

The Orbán Effect: EU Conservatives Have a Hungary Problem, "Spiegel" 2013, available at http://www.spiegel.de/international/europe/hungarian-government-puts-european-conservatives-in-tough-spot-a-902620.html, accessed 7 January 2016.

R. Torres, L. Ponce de León, Reislamización digital y yihadismo europeo: claves comprensivas para la intervención social comunitaria, "Sistema”, no. 240, 2015.

Treaty of Amsterdam, 1997, available at http://europa.eu.int/eur-tex/es/search/ search_treaties.html, accessed 4 December 2015.

UK-Parliament, Money laundering and the financing of terrorism, available http:// www.publications.parliament.uk/pa/ld200809/ldselect/ldeucom/132/132ii. pdf, 2009, accessed 9 January 2016.

United Nations, Convention Against Transnational Organized Crime and the Protocols Thereto, 2004, available at https://www.unodc.org/documents/middleeastandnorthafrica/organisedcrime/UNITED_NATIONS_CONVENTION_AGAINST_TRANSNATIONAL_ORGANIZED_CRIME_AND_THE PROTOCOLS_THERETO.pdf, accessed 9 January 2016.

United Nations, Vienna Convention on the law and teatries, 2004, available at https://treaties.un.org/doc/Publication/UNTS/Volume\%201155/volume-1155-I18232-English.pdf, accessed 9 January 2016.

United Nations, International Convention for the Suppression of the Financing of Terrorism, 1999, available at http://www.un.org/law/cod/finterr.htm, accesses 19 December 2015.

United Nations, Guia legislativa del régimen jurídico universal contra el terrorismo, 2008, available at https://www.unodc.org/documents/terrorism/Publications/ 
Legislative_Guide_Universal_Legal_Regime/Spanish.pdf, accessed 18 October 2015.

United Nations, The Globalization of Crime: A Transnational Organized Crime Threat Assessment, 2010, available at https://www.unodc.org/documents/dataand analysis/tocta/TOCTA_Report_2010_low_res.pdf, accessed 19 December, 2015. 



\section{An Analysis of the Psycho-Social Factors Involved in Jihadist Radicalization Process and Terrorist Violence}

\section{Introduction}

Jihadist terrorism generates a profound debate on how a free and peaceful society should face a threat of these characteristics. The global situation points to this social problem as something structural, which will continue into the future without being solved in the short term. ${ }^{1}$ To face it, it is necessary to combine the efforts of a whole society in looking for solutions.

Mankind is facing extreme violence of proportions that are very different from what we have seen historically in parts of the world threatened by terrorism and violent movements. A differentiating element of jihadist terrorism is the act of suicide. It also shares similarities with other forms of extreme violence whose objective is the control and domination of all humanity: theoretically, looking for benefits for society, but actually, causing serious harm to not only non-Muslims but to the Muslim culture in general.

The jihadist radicalization process has not grown spontaneously, or recently. In fact, it has been growing and consolidating for many years, developing its uses, becoming ever more sophisticated to increase its power of attracting new recruits. The messages of terrorist groups occupy an important place in this process. These groups persistently send messages favoring a certain education and instructing their recruits to do everything within the parameters which they dictate. They send seductive messages that appeal to most urgent personal needs, or threatening messages which set out the boundaries of behavior, thought and attitudes which are permitted or allowed: messages generating ambivalence, misleading, excluding, cheating and shrouding, messages that, in addition, invite the use of extreme violence for the attainment of certain objectives that they consider legitimate. ${ }^{2}$

1 J. Victoroff, Suicide Terrorism and the Biology of Significance, "Political Psychology", no. 20, 2009, pp. 397-400.

2 L. Veres, Imagen, terrorismo y argumentación, "Revista Iberoamericana de Argumentación", no. 4, 2012, pp. 1-14. 
We do not have enough information about psychological and social factors affecting this process, even when we try to isolate the characteristics differentiating a person who is committed to radicalism and violence from those who are not. In fact, the reactions that an individual can reproduce when facing a certain social pressure are very broad. Some of them opt to fight to maintain their freedom, being attacked, while others join the terrorist cause. Therefore, the psychological and social variables must be studied to understand the complexity of the process and to be able to stop it and fight against it. Studying them poses great difficulties and a huge challenge when strategies are established to permit the understanding, prevention and eradication of this social scar. ${ }^{3}$

One of the collateral effects of the problem with Islamic terrorism is the general confusion that is provoked regarding the perception of Muslim culture. It has generated a feeling of hate against Muslims in Europe, increasing the negative perception already present before the jihadist threat. ${ }^{4} \mathrm{~A}$ link between Jihadism and Muslim society has been created, based on ignorance, which has created a general social image far from objective reality. Actually, jihadist terrorism is a minority of the society that it claims to represent, creating an image that mistakenly links a culture with the concept of violence and terrorism. In spite of this unfortunate link, it is no more violent than any other might be.

This article intends to establish the causes and factors related to the jihadist radicalization process, the social and psychological factors and the role played by the different spheres of society and culture, through personal, political and religious socialization, through family, school, social movements, the media and so on. Its goal is to complete an analysis allowing us to draw conclusions to build the necessary strategies to be implemented by peaceful societies intended to fight against Islamic terrorism, and to prevent the radicalization of individuals.

\section{Violence and Terrorism}

\subsection{Aggression and violence}

To be able to deepen the understanding of terrorist violence, we first need to ask whether violence is a natural or cultural phenomenon. It is in this debate that the

3 H.M. Trujillo, Hacia una mejor comprensión psicológica del terrorismo: reclutamiento, ideología y violencia, "Revista de Psicología Social", no. 24, 2009, pp. 163-181.

4 Z. Strabac, O. Listhung, Anti-Muslim prejudice in Europe: a multilevel analysis of survey data from 30 countries, "Social Science Research", no. 37, 2008, pp. 268-286. 
difference between the concepts of violence and aggression becomes particularly relevant.

Aggression is a biological feature that can be found in every living being and that serves to increase the biological efficacy of the species. Therefore, it is not necessarily a negative characteristic; it is acquired through evolution, if we believe in an adaptive response which is a part of the facing strategies present in all human beings. ${ }^{5}$

The World Health Organization defines violence as, "The intentional use of physical force or power, threatened or actual, against oneself, another person, or against a group or community that either results in or has a high likelihood of resulting in injury, death, psychological harm, maldevelopment or deprivation." 6 The definition includes interpersonal violence, suicidal behavior and armed conflicts. It refers not only to perpetrated violence but also to acts intended to generate damage, such as threats or intimidation. It highlights the importance of the consequences not only at the physical level but also at the psychological one: psychical damage, privations, development impairments, which are less visible but highly damaging for the people's wellbeing.

Violence is a perverse configuration of aggressiveness with a destructive character over people; it is a social dysfunction, as it means a loss of its adaptive character. It is useless from a biological point of view and deliberate from a psychological point of view. ${ }^{7}$

We can talk about aggression as something innate, biological, inevitable and able to be molded by culture, and about violence as something human, avoidable, non-biological and cultural. Violence is useless from a biological point of view and the result of the interaction between natural aggression and culture. In this way, violence is molded by different psychological, cultural and social factors. ${ }^{8}$

Violence is specifically human, being a product of culture and socialization. ${ }^{9}$ It is an intended behavior destined to obtain domination and control, using force in an explicit or implicit manner, with the aim of obtaining from a person or group

5 J. Sanmartín, Agresividad y violencia, in: El laberinto de la violencia. Causas, tipos y efectos (ed.) J. Sanmartín, Ariel, Barcelona 2004, p. 21.

6 World Health Organization, Violence: a public health priority. Global Consultation on Violence and Health, available at http://www.who.int/violence_injury_prevention/ violence/world_report/en/introduction.pdf, accessed 6 January 2016.

7 E. Echeburúa, P. De Corral, Raíces psicológicas del fanatismo político, "Análisis y modificación de conducta”, no. 30 (130), 2004, pp. 161-176.

8 P. Imbusch, The concept of violence, in: International Handbook of Violence Research W. Heitmeyer, J. Hagan (eds.), Kluwer, Netherlands, 2003, pp. 13-39.

9 J. Sanmartín, La violencia y sus claves, Ariel, Barcelona 2000. 
of people what they do not want to freely consent to. Research has already shown that it is a product or co-occurrence in time of several interrelated factors. ${ }^{10}$ Johan Galtung ${ }^{11}$ points out three types of violence:

- Direct violence, which refers to physical and/or verbal violence, which is the most visible type and the one referred to by most people; it is the one where we can identify victims and also killers.

- Structural violence, which is a part of the social structure and its mechanism. It is easy to identify the victims but not the killers, as the origin is not in specific people.

- Cultural violence refers to the group of values, ideas and convictions used to justify or legitimize structural or direct violence, and is the one that gives the perception of normality in its exercise.

Galtung suggests that these three types of violence are intimately related, in the fact that both the structural violence and the cultural violence are detonators for the diverse manifestations of direct violence. This approach has political and analytical consequences. Regarding jihadist terrorism, for instance, it forces us not only to analyze the attacks and their victims, but also to challenge the structural and cultural tendencies sustaining terrorism. In light of this approach, to eradicate jihadist terrorism is to change the educational and the cultural norms which maintain it.

\subsection{Terrorist violence}

Not all violent acts are acts of terrorism, but all terrorist acts are acts of violence. What makes the difference between terrorist violence and other kinds of violence is generally the intention behind them. Violence is aimed at achieving ideological objectives -religious, ethnical, political - that serve as a support and justification, and that are based on control, impulsiveness and hate. ${ }^{12}$

Speaking of terrorism implies highlighting the existence of two important characteristics, the first one is that it is directed toward people, and the second one, that this violence intends to influence people's perception to incorporate them, by their own will or not, to the terrorist cause through fear and violence. ${ }^{13}$

10 R. Borum, Psychology of terrorist, University of South Florida, Tampa 2004.

11 J. Galtung, Cultural Violence, "Journal of Peace Research" no. 27(3), 1990, pp. 291-305.

12 H.M. Trujillo, Hacia una mejor comprensión psicológica del terrorismo: reclutamiento, ideología y violencia, "Revista de Psicología Social”, no. 24, 2009, pp. 163-181.

13 K. Aulestia, Historia general del terrorismo, Aguilar, Madrid 2005. 
Jihadist terrorism is a global terrorism having as its target everyone who is not a follower of that particular strain of Islam, including those who follow other tendencies of Islam.

Ideology is a key aspect in understanding terrorist violence, which in the field of psychology becomes a model to explain terrorist behavior and the dichotomy of the moral filter used by terrorists, allowing them to commit atrocities for a "good cause." We consider ideology to be a group of accepted norms following an individual's beliefs, values, principles and purposes, ${ }^{14}$ that allow the justification of violent behaviors. In the terrorist's mind, the conviction remains that his actions are justified as a means to obtain what is deemed fair. ${ }^{15}$ In studies linking extremist ideology with terrorism, ${ }^{16}$ we see that an environment characterized by the extreme radicalization of the ideas is, without doubt, a trigger for terrorism.

Terrorist violence has grown and evolved over the years and now confronts us with a new form of terrorism with very different characteristics to what the world had experienced up to now. Considering this evolution, some authors have referred to "old terrorism" and "new terrorism"17 applying the first term to the groups in search of political power, independence or nationalism, and the second to the groups having mainly religious motives.

The value given to human life is a key characteristic of jihadist terrorism, compared with other forms assumed by terrorism, in which the terrorist tries to keep his own life. The final objective is to cause as much damage as possible, looking for the greatest glory. It is a battle in what is called holy war against the unbelievers. For them, the Western countries are not only where the unbelievers live but also an unholy land that is not under the protection of their God. This land is yet to be conquered. Generally, terrorist movements claim the rights over other territories. For the Islamic terrorists, the whole world is their territory because it is the territory of their God. It is terrorism with a global perspective, directed against all unbelievers.

In addition, to accomplish their terrorist acts, jihadist groups make use of drugs to have enough courage to carry out violent acts. The use of drugs, together with the process of indoctrination (for example, the de-humanization of the victim, the attribution of the fault to the victim, among others), contributes to the inhibition of those psychological processes, social values and moral brakes

14 C. J. Drake, The role of ideology in terrorists'target selection, "Terrorism and Political Violence" no. 10, 1998, pp. 53-85.

15 F. Alonso-Fernández, Fanáticos Terroristas, Masson, Madrid 2002.

16 I. Martín-Baró, Poder, ideología y violencia, Trotta, Madrid 2003.

17 A. Spencer, Questioning the concept of New Terrorism, "Peace Conflict and Development" no. 8, 2006, pp. 1-33. 
that work against such destructiveness and violence. ${ }^{18}$ It is a kind of contrived terrorism, with studied and designated targets, which powerfully represents the religious act through death sacrifice that, in addition, offers an example which others can imitate and to adore.

The terrorist investigation, in spite of its growth over the last years, has rarely been evaluated by means of empirical methods, which is why the challenge of expanding scientific methods is now being set up, from a rigorous and systematic perspective, for this social problem.

\subsection{Suicidal jihadist terrorism}

Suicide terrorism constitutes a new phenomenon different from other forms of violence and terrorism. It is difficult to understand the process of bringing someone to push to an extreme his behavior up to the point of taking his own life as a destructive element to cause the greatest possible harm. It would be easy to refer to a mental illness to explain such a complex phenomenon, but research shows that suicide terrorism corresponds to several complex causes,

Suicide attacks can be defined as a violent, politically motivated acts executed by one or more individuals, in which completing the terrorist act depends on the death of the terrorist carrying it out. These operations are less expensive, and can be easily organized, without having to activate any runaway device. Suicide attacks manage to kill four times more people than other terrorist acts, and they also have a very important impact on the media that guarantees a great deal of attention on the terrorist and his message. ${ }^{19}$

Islamic fundamentalist groups confer a divine character on the act of suicide, considering the dead terrorists as martyrs whose objective was to accomplish an order: jihad (understood as the individual necessary effort to successfully achieve what you intend to do). In this way, they are recognized as victims and obtain eternal life in paradise for this sacrifice. Through religious influence, the individual can find a sense of satisfaction in his death and later recognition, creating an image which favors the preparation process for a suicide attack. From this point of view, socialization, understood as a process for which human beings incorporate

18 G. LaFree, G. Ackerman, The Empirical Study of Terrorism: Social and Legal Research, "The Annual Review of Law and Social Science", no. 5, 2009, pp. 347-374.

19 M. Torres, El Terrorismo Suicida y sus Desafíos, available at http://www.upo.es/export/ portal/com/bin/portal/upo/profesores/mrtorsor/profesor/1214214328678_suicida_ escaneado.pdf, accessed 6 January 2016. 
rules, values, attitudes and conduct, contributes to generating a concept of death which favors suicide terrorism.

Its novelty and variety makes it difficult to establish a profile that would allow us to identify those individuals who might respond to extremist organizations' calls to commit suicide attacks. Besides, we could add how difficult it is to use a psychological approach based on hypotheses, as it is not possible to analyze the psychological characteristics of those who commit suicidal terrorist acts precisely because the perpetrators are left dead in the attack. There is a wide variety of variables in terms of age, education, nationality, and gender. The meaning, motives, and causes of suicide attacks remain unclear. ${ }^{20}$ They can be related to religion, nationality, ideas or revenge. Intense indoctrination and a repressive social and political system can be the elements that push an individual toward such an extreme conduct.

\section{Radicalization and Recruitment as a Psychosocial Process}

Radicalization can be defined as an increasing extremity of beliefs, feelings, and behaviors in support of an intergroup conflict and violence, ${ }^{21}$ so that individuals are prepared for social conflict, modifying elements that justify intergroup violence and promote commitment and personal sacrifice in defense of a cause deemed just by the radical groups. The violent radicalization process allows certain individuals to become terrorists, led by factors such as injustice (whether perceived or real), social exclusion, religious extremism, social unacceptance or discrimination..$^{22}$

Of course, the radicalization process is driven by the creation of group identities. ${ }^{23}$ It is based on cultural and social elements which influence individual ideologies. Erving Goffman's interpretive frames theory offers a good description of how shared meanings are built within each group. Goffman defines an interpretive frame as a set of action-oriented beliefs and meanings. The interpretive

20 D. Gambetta, Making sense of suicide missions, Oxford University, Oxford 2005.

21 C. McCauley, S. Moskalenko, Mechanisms of Political Radicalization: Pathways Toward Terrorism, "Terrorism and Political Violence", no. 20, 2008, pp. 415-433.

22 European Commission, Communication from the Commission to the European Parliament and the Council concerning terrorist recruitment - Addressing the factors contributing to violent radicalisation, 2005, available at (http://eur-lex.europa.eu/ legal-content/EN/TXT/?qid=1452973247690\&uri=CELEX:52005DC0313), accessed 6 January 2016.

23 E. Goffman, Frame Analysis: An Essay on the Organization of Experience, Harper and Row, London 1974. 
frames legitimate and inspire social movement activities, provide meaning to participants, and build their personal and collective identity. In this case, the ideological and cultural interpretive frames would be the ideas, traditions, political speeches, language, mental attitudes, symbols, rituals, myths and values. Through them, all individuals joining jihadism progressively delegate their own identity in the name of the supreme mandate led by the group's ideology, reinforcing its radicalization on a daily basis.

The jihadist's ideological radicalization is an initial step to performing terrorist acts. Even though not all radicals are terrorists, we can affirm that all terrorists have gone through a similar process. This process feeds on different psychological and social situations like social alienation, racism or discrimination, identity problems that mix frictions of Muslim and Western cultures, psychological factors such as depression, frustration or family problems. Through the use of sophisticated propaganda systems, the extremists offer a sense of belonging and existential meaning, mixed with a promise of salvation. They also claim their movement to be Islam's purest representation.

When analyzing the attraction and recruitment process, it should also be taken into account that sometimes extremists offer salaries, which, for some youngsters with no future, can be the only option for personal development and subsistence. In this way, the Islamic State offers attractive financial incentives crucial for them to join the jihadist fight.

Places like mosques, prisons or certain neighborhoods can be breeding grounds for terrorist recruitment, especially for those with characteristics more prone to radicalization. It is also true that self-recruiting is increasing due to the Internet and social networks. ${ }^{24}$

\section{Analysis of Key Factors Contributing to Jihadist Radicalization according to the Ecological Model}

In order to analyze Islamic terrorism one has to determine its etiology and indicators that might be associated with the origin and persistence of the phenomenon. Despite the complexity of determining which are the exact motivations that lead

24 A. Kirby, The London Bombers as Self-Starters: A Case Study in Indigenous Radicalization and the Emergence of Autonomous Cliques, "Studies in Conflict and Terrorism", no. 30, 2007, pp. 415-428. 
someone to opt for jihadism, the most common factors accompanying them are identifiable. $^{25}$

Terrorist violence can only be understood through the ecological model, since it offers a multi-causal explanation of the complex phenomenon and points out three different levels: Macrosystem, Exosystem (intermediate), and Microsystem.

\section{The Macrosystem:}

The macrosystem implies political, social, economic and even cultural indicators that shape the society to which a future radicalized individual initially belongs. The belief systems, radical ideas and cultural guidelines which justify and support terrorist violence provide the grounds for the acceptance of Islamic terrorism.

Even though this level's influence on radicalism seems obvious and there is a consensus about it, it is not possible to specify precisely which elements would allow us to predict with certainty an individual or collective radicalization. ${ }^{26}$ As an example, we can point to the widespread diffusion of jihadist ideology, which is necessary at that level to generate a framework for collective alignment, but which does not completely explain violence on its own. ${ }^{27}$

\section{The Exosystem:}

The Exosystem includes the context where social relations take place such as work, family, school, friends, religious forums, influence of radical leaders, and so on. These community referents facilitate or neutralize the emergence of a fundamental reference framework that normalizes, promotes and accelerates the radicalization processes. The actors and structures at this level allow the macro level factors to settle and crystallize in the individual. For example, belonging to a group provides great power to transmit norms and behaviors, and even shapes the individual's self-esteem. ${ }^{28}$ At the same time, messages sent by different agents from outside the

25 J. Horgan, Psychological Factors Related to Disengaging from Terrorism. Some Preliminary Assumptions and Assertions, in: A Future for the Young. Options for Helping Middle Eastern Youth Escape the Trap of Radicalization Ch. Bernard (ed.), Rand Corporation, Santa Monica 2005, pp. 65-91.

26 J. Jordán, Procesos de radicalización yihadista en España. Análisis sociopolítico en tres niveles, "Revista de Psicología Social", no. 24 (2), 2009, pp. 197-216.

27 J. Waller, Becoming Evil. How Ordinary People Commit Genocide and Mass Killing, Oxford University Press, Oxford 2007.

28 O. Roy, El islam mundializado. Los musulmanes en la era de la globalización, Bellaterra, Barcelona 2003. 
group, for example non-jihadists, exert much less influence. Alonso and Berlel ${ }^{29}$ talk about the risk of loss of individual identity in vulnerable subjects, in favor of an increase in group identity. If the estrangement at the macro level is great, the exosystem has more influence in the radicalization process.

Risk factors, such as unemployment, social network sites filled with radical messages, social isolation, exclusion or absence of integrative programs, or even pertaining to homogeneous groups that remain not integrated - for example, Muslim migrants amongst others - can lead to facilitating and increasing radicalization. This level is of crucial importance in the recruitment of subjects as well as in their reintegration. That is why it is necessary to look deeply into it in order to work on the prevention and eradication of terrorism.

\section{The Microsystem:}

The microsystem relates to the individual part of a person, that is to say, to all psychological and biological factors and personal history. It also includes the cognitive, behavioral, affective and interactional characteristics, the influence of close relationships to increase the permeability of becoming a radical (for example, through a partner).

There are many myths related to the mental health or illness of terrorists, stating that such acts cannot possibly be perpetrated by mentally healthy people. We cannot establish the terrorists' personality disorders, psychopathy, or mental sickness as a cause of jihadist terrorism, since most of these people are not sick; they are aware of their acts and take full responsibility for them. However, we may talk about a social disease. In spite of the scarce data on this subject and the need to further investigate the psychological indicators, we would be facing fanatical people who have a biased interpretation of the facts, hostile attitudes, and who are convinced that the only way to reach their goals is through the use of violence. ${ }^{30}$ This model emphasizes how vulnerable personalities and conductible surroundings explain the development of radicalism.

We cannot talk about a radical prototype nor isolate the combination of variables that guarantee the individual's radicalization; he can be of any age, nationality, social or cultural level. The experience shows that we should add different characteristics to the three levels that together can create triggers of the radical process.

29 R. Alonso y S. Berbell, Procesos grupales e intergrupales, in: Psicología de los grupos. Teoría y aplicaciones P. González (ed.), Síntesis, Madrid 1997, pp. 759-810.

30 F. Reinares, Perfil del terrorista, in: El laberinto de la violencia. Causas, tipos y efectos, J. Sanmartín (ed.), Ariel, Barcelona 2004, pp. 283-290. 


\section{Prevention of Jihadism Radicalization}

Governments now incorporate the fight against terrorism as a priority. Until recently, they have been primarily reactive to terrorist challenges, but now they accept the need to incorporate a proactive vision. It is necessary to review the policies that have been developed in the fight against jihadi terrorism and look for more global ways to bet on prevention. Prevention can be no longer seen as an exclusive prerogative of governments; the whole society has to be involved in the terrorism eradication.

There is no doubt that analyzing more effective prevention strategies implies knowing, revising, and incorporating the political, social, historical and economic factors at an international level, and their influence on jihadist terrorism. Here we will focus on analyzing, from a psychological and social perspective, the basic initiatives - mainly those involving the micro and meso levels of the ecological model - without forgetting that these initiatives have to be put together with the macro level measures that will be addressed in other chapters of this book.

Prevention needs to be addressed at three different levels, which we shall now discuss.

When the conflict has not yet surfaced, it is necessary to run interventions on the population in general, oriented to foster respect, equality, tolerance and non-violence, removing social and cultural obstacles that generate hate and discrimination. This dimension needs to be developed within the culture itself and directed toward other cultures.

Education in values is a key aspect when preventing terrorist violence in our society. To build a society based in equality and respect, it is necessary to work from early schooling through the whole education process. Likewise, we need to remove the mechanisms that promote racist situations and violence, to actively confront them, favoring cognitive, affective and behavioral changes radically opposed to those promoted by terrorism.

The macro strategy to fight terrorism must integrate a perspective on the defense of human rights helping to discover that these problems damage not only the more visible victims but also the whole society. It is advisable to stimulate among the population the capacity to put themselves in someone else's place, the understanding of universal rights and the ability to use such understanding in each and every moral decision, linking such rights with the (also universal) duty to respect them. In that sense, religions and religious leaders must be an example of peace, integration and tolerance, promoting human rights in the world and condemning any violent practice in the name of faith. 
The media are a privileged source of information and influence. They have an undeniable capacity to construct reality, transmit ideology and present behavioral models that turn them into a powerful platform to spread symbols, beliefs and values prevailing in our society; they also function as an agent or mediator in the socializing process. The media's role is necessary to offer positive and real models of peaceful coexistence, ${ }^{31}$ to transmit values that eradicate religious or ethnic discrimination, to give voice to those with strong and motivating ideas that discourage individuals away from the radicalization process and generate identification alternatives.

Secondary prevention must be addressed to the academic, working, family, social, religious and custodial contexts, and must be focused on intervening in the social problems that may generate discrimination and social exclusion (unemployment, lack of housing, racism, poverty, discrimination), and on psychological and emotional problems (psychological problems and disorders, emotional deficit, self-esteem problems). ${ }^{32}$ Both the social and psychological dimensions play an important role in encouraging the radicalization process. From the personal sphere, fostering the construction of one's own positive identity, that allows teenagers to discover what they want to be, and to take adequate decisions that will be put into practice in the future, becomes a watertight barrier against extremist ideologies.

Finally, the third stage is directed to those already affected by radicalization, developing psychological and social intervention processes that enable their social reintegration. This would be without diminishing or replacing any legal sentences for the consequences of their actions. To that end, new intervention models need to be developed to allow the revision of their ideology and the change of their strategies in order to deradicalize them.

\section{Conclusion}

Jihadist terrorism represents a threat against human security on a global scale, creating the need for joint global intervention. It grows and evolves acquiring singular and unpredictable forms, spreading collective terror and maintaining its goal of causing severe damage to the societies where it appears. In order to eradicate it, it is important to search for efficient, global strategies that do not

31 O. Ashour, The De-Radicalization of Jihadists. Transforming Armed Islamist Movements, Routledge, New York 2009.

32 R. Borum, Radicalization into Violent Extremism II: A Review of Conceptual Models and Empirical Research, "Journal of Strategic Security", no. 4, 2011, pp. 37-62. 
generate more victims or violence and that take into account that any attempt of eradication will find strong resistance.

Based on its very definition, and as well as its difference to aggression, we can affirm that we are facing extreme violent behaviors, produced and maintained by society and culture, unnecessary for human survival, and whose analysis has to transcend the specific acts of direct violence perpetrated by the terrorists, to go deep into the roots of the structural and cultural violence that justify these acts.

In order to be able to eradicate jihadist terrorism, we need to relate it to other forms of violence and to know the role of different social agents, states and even society, with the aim of eliminating any escalation in what we might call a spiral of violence. To that end, we must incorporate a global peace strategy, introducing non-violent elements as the only way to cut the Gordian knot of violence. We must not forget that the more harm violence provokes, the more complex it becomes to combat it in a peaceful way.

Jihadi terrorist groups use a strong message which is able to create an ideology and transmit values that modify thoughts, feelings and attitudes in some people, transforming them into radicalized individuals who join their violent cause. Their first aim is to stimulate the need to belong to a chosen minority fighting for a supreme goal.

Social sciences play a fundamental role in the study of the processes of radicalization and recruitment, due to the necessity of incorporating a general vision in the analysis. The goal is to provide an answer to the question of how to prevent someone's radicalization. Moreover, it is important to develop a strategy of intervention concerning those who have already become radicalized. It is not possible to know for sure which are the elements that influence the radicalization process, we have no conclusive certainties that allow us to describe, understand, predict and prevent terrorist behavior.

The ecological model applied to terrorism provides an essential global and multi-causal vision of the interactions in individual, family, academic, social and media contexts that any analysis and proposal for action should keep in mind.

Preventing and reducing terrorist violence implies changing the norms and values that tolerate and encourage it, as well as anything reinforcing attitudes prone to radicalization. To reduce the impact of this process, it is necessary to minimize the scope of the extremist socializing agents and, at the same time, to create alternatives resistant to that ideology. The promotion of values incompatible with violence and radicalization - respect, tolerance, empathy, and so on - has to be at the heart of prevention strategies, intervening at every stage of the person's evolution, especially in childhood education, but also including the development 
of preventive actions directed at re-educating of adults. Moreover, a clear and powerful message must be spread in order to raise people's awareness and promote more peaceful attitudes.

Once we have become aware of the scale of the problem, there is no other option but to establish a genuine dialogue between cultures and religions, to look for peace and harmony among different beliefs and block any ideology that infringes upon human rights, searching for spaces to build strengths against any kind of discrimination or violence.

The tendency to criminalize Muslim culture as a consequence of its link with jihadist terrorism fosters a culture of hate and discrimination. Official doctrines must emerge and become visible to point the real and accurate interpretation of the sacred texts and provide some distance from extremist interpretations, looking for a greater knowledge, awareness and integration of the different cultural and religious perspectives internally and among cultures. Muslim leaders play an important role in the neutralization of jihadist messages and in the construction of alternatives.

It is necessary to work for the integration of Muslim immigrants' identity to grant them full citizenship access. To that end, we need to analyze the exclusion and social vulnerability they suffer. Even though these factors do not completely explain the terrorist's behavior, they represent a risk factor, in the same way that the process of social inclusion provides a psychological, economic and social balance, contributing to self-esteem, independence and the feeling of being valuable. All these factors are important in terms of protection. Working for real and effective social inclusion through positive actions represents a strong prevention strategy.

\section{References}

F. Alonso-Fernández, Fanáticos Terroristas, Masson, Madrid 2002.

R. Alonso, S. Berbell, Procesos grupales e intergrupales, in: Psicología de los grupos. Teoría y aplicaciones P. González (ed.), Síntesis, Madrid 1997.

O. Ashour, The De-Radicalization of Jihadists. Transforming Armed Islamist Movements, Routledge, New York 2009.

K. Aulestia, Historia general del terrorismo, Aguilar, Madrid 2005.

R. Borum, Psychology of terrorist, University of South Florida, Tampa 2004.

R. Borum, Radicalization into Violent Extremism II: A Review of Conceptual Models and Empirical Research, "Journal of Strategic Security", no. 4, 2011. 
C. J. Drake, The role of ideology in terrorists' target selection, "Terrorism and Political Violence" no. 10, 1998.

E. Echeburúa, P. De Corral, Raíces psicológicas del fanatismo político, "Análisis y modificación de conducta", no. 30 (130), 2004.

European Commission. 2005. Communication from the Commission to the European Parliament and the Council concerning terrorist recruitment - Addressing the factors contributing to violent radicalization, available at (http://eur-lex.

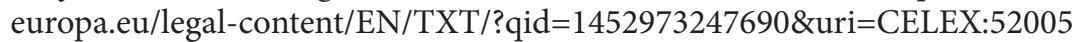
DC0313), accessed 6 January 2016.

D. Gambetta, Making sense of suicide missions, Oxford University, 2005 Oxford.

J. Galtung, Cultural Violence, "Journal of Peace Research", no. 27(3), 1990.

E. Goffman, Frame Analysis: An Essay on the Organization of Experience, Harper and Row, London 1974.

J. Horgan, Psychological Factors Related to Disengaging from Terrorism. Some Preliminary Assumptions and Assertions, in: A Future for the Young. Options for Helping Middle Eastern Youth Escape the Trap of Radicalization Ch. Bernard (ed.), Rand Corporation, Santa Monica 2005.

P. Imbusch, The concept of violence, in: International Handbook of Violence Research W. Heitmeyer, J. Hagan (eds.), Kluwer, Netherlands 2003.

J. Jordán, Procesos de radicalización yihadista en España. Análisis sociopolítico en tres niveles, "Revista de Psicología Social", no. 24 (2), 2009.

A. Kirby, The London Bombers as "Self-Starters: A Case Study in Indigenous Radicalization and the Emergence of Autonomous Cliques, "Studies in Conflict and Terrorism", no. 30, 2007.

G. LaFree, G. Ackerman, The Empirical Study of Terrorism: Social and Legal Research, "The Annual Review of Law and Social Science", no. 5, 2009.

I. Martín-Baró, Poder, ideología y violencia, Trotta, Madrid 2003.

C. McCauley, S. Moskalenko, Mechanisms of Political Radicalization: Pathways Toward Terrorism, "Terrorism and Political Violence", no. 20, 2008.

F. Reinares, Perfil del terrorista, in: El laberinto de la violencia. Causas, tipos y efectos J. Sanmartín (ed.), Ariel, Barcelona 2004.

O. Roy, El islam mundializado. Los musulmanes en la era de la globalización, Bellaterra, Barcelona 2003.

J. Sanmartín, Agresividad y violencia, in: El laberinto de la violencia. Causas, tipos y efectos J. Sanmartín (ed.), Ariel, Barcelona 2004.

J. Sanmartín, La violencia y sus claves, Ariel, Barcelona 2000.

A. Spencer, Questioning the concept of New Terrorism, "Peace Conflict and Development" no. 8, 2006. 
Z. Strabac, O. Listhung, Anti-Muslim prejudice in Europe: a multilevel analysis of survey data from 30 countries, "Social Science Research", no. 37, 2008.

M. Torres, El Terrorismo Suicida y sus Desafíos, available at http://www.upo.es/export/portal/com/bin/portal/upo/profesores/mrtorsor/profesor/1214214328678_ suicida_escaneado.pdf, accessed 6 January 2016.

H. M. Trujillo, Hacia una mejor comprensión psicológica del terrorismo: reclutamiento, ideología y violencia, "Revista de Psicología Social", no. 24 (2), 2009.

J. Victoroff, Suicide Terrorism and the Biology of Significance, "Political Psychology", no. 20, 2009.

J. Waller, Becoming Evil. How Ordinary People Commit Genocide and Mass Killing, Oxford University Press, Oxford 2007.

L. Veres, Imagen, terrorismo y argumentación, "Revista Iberoamericana de Argumentación", no. 4, 2012, pp. 1-14.

World Health Organization, Violence: a public health priority. Global Consultation on Violence and Health, available at http://www.who.int/violence_injury_prevention/violence/world_report/en/introduction.pdf, accessed 6 January 2016. 


\section{Anna Potyrała \\ Islamic State - Disputed Statehood}

\section{Introduction}

In June 2014, a terrorist group calling itself "Islamic State" proclaimed itself as a caliphate. After seizing large territories of Syria and Iraq, establishing a basis of administration and gaining control over the population inhabiting captured areas, the group announced a state governed in accordance with the Islamic law by a caliph. Reactions of the international community members were easy to predict. In official declarations, states, as well as international organizations, notified their refusal to recognize statehood of the new entity. Nevertheless, a real problem has been faced: how to deal with an entity engaged in terrorist activities, and therefore posing a real threat to international peace and security, but at the same time claiming to be a sovereign, independent state? Are these claims in accordance with international law if the entity has violated principles of territorial integrity, sovereign equality and inviolability of borders - all these of a ius cogens character? The aim of the analysis is to verify the hypothesis according to which, in case of the so-called Islamic State's proclamation of caliphate, the entity established cannot be treated as a state, as it has no legal personality in international law and, accordingly, is not a recognized member of the international community. For this reason, the international law criteria concerning statehood will be analyzed in light of the determinants of statehood formulated in international practice. Consequently, reasons against the IS statehood will be specified. Among them, not only criteria of statehood, but references to international response will be formulated. The text will not focus on the historical background of the IS establishment, nor on military activities of this group, but only on the issue of statehood.

\section{The Criteria of Statehood according to International Law and Practice}

According to the classical definition provided by Georg Jellinek, a state is characterized by three elements: territory, population living on that territory and government exercising authority over the population and the territory. ${ }^{1}$ The first

1 See: J. R. Crawford, The Creation of State in International Law, Oxford University Press, Oxford 1979, pp. 36-47. 
element is regarded as any area which is subjected to exclusive rights and interests of a particular state-entity. Whilst a state can exist if it loses control over its territory - as a result of a conflict, for instance - it cannot be proclaimed without it. $^{2}$ The size of the territory, as well as its location, composition (land territory with rivers, lakes etc., the subsoil, the air space, maritime areas in case of coastal states) is not relevant. The second element refers to a group of persons subjected to a government authority and living permanently in a defined territory. ${ }^{3}$ The last element - government - means an organization or an organ of a political and administrative character, able to control all aspects of the state functioning and responsible for vindication of rights and obligations of this entity. This is the crucial task of government: not only to guarantee territorial integrity and the existence of a state but also to control behavior of its inhabitants. According to Hans Kelsen, a state: "is the specific union of individuals, and this union is the function of the order which regulates their mutual behaviour." ${ }^{\prime \prime}$ Therefore, stability and effectiveness are its key characteristics.

Nonetheless, such a three-element understanding has been formulated only for the purposes of internal functioning of a state. One must assume that, from the point of view of international law and international relations, the abovementioned definition should be complemented with two additional elements. The reason is that an entity can be treated as a state only so long as it has the capacity of being a bearer of rights and duties defined in the international law, as well as of acting with legal effect, especially concluding international agreements, establishing diplomatic and consular relations, being a member of international organizations, being internationally responsible or having privileges and immunities. Therefore, territory, population and government do not constitute a state in the international law and international relations.

Although, there is no universal international agreement pointing out conditions necessary to be fulfilled by an entity which applies for an international legal status of a state, in 1933 a four-element definition was introduced. According to the Montevideo Convention on Rights and Duties of States, apart from a defined territory, a permanent population and government, "capacity to enter into relations with the

2 See: Th. Grant, Defining Statehood: The Montevideo Convention and its Discontents, "Columbia Journal of Transnational Law" no. 37, 1999, pp. 435.

3 "It does not mean that there can be no migration of peoples across territorial boundaries": M. Dixon, Textbook on International Law, Oxford University Press, Oxford 2013, p. 119.

4 H. Kelsen, The Pure Theory of Law and Analytical Jurisprudence, "Harvard Law Review" no. 55,1941, p. 44. 
other States" is necessary for statehood, ${ }^{5}$ for only in relations with other states a given state is able to function actively in the international arena and to fulfill its objectives.

Another crucial element constituting a state in international law and international relations is sovereignty, defined in accordance with the decision on the Island of Palmas as "independence. Independence with regard to a portion of the globe is the right to exercise therein, to the exclusion of any other State, the functions of a State." ${ }^{\prime}$ According to Ludwik Ehrlich, sovereignty can be perceived as independence from any other authority both in the internal sense (absolute authority, i.e. the authority of a state on its territory is primary, highest, exclusive and unlimited) and in the external sense (self-rule, i.e. independence from other states, but not from all external factors). Sovereignty implies a full capacity to perform legal transactions in the international arena and the protection of the legal status of a State in the form of mandatory standards prohibiting certain actions against States in their mutual relations. ${ }^{7}$

And although statehood depends only on meeting the aforementioned criteria, ${ }^{8}$ the actual functioning of a state in the international arena is strictly connected to international recognition. Without a formal consent expressed by other states, a state entity remains a "non-entity." It is difficult for an entity which has not been recognized or which has gained recognition only of a limited number of states, to exercise certain rights granted to it under the international law; it does not participate in international "life" or does it to a limited extent. ${ }^{10}$ An entity, which is not internationally recognized, cannot fully benefit from e.g. being a member of international organizations, concluding treaties, the right of legation and the right to send and receive consular officers, as well as from privileges and immunities for its representatives.

5 Montevideo Convention on the Rights and Duties of States, 1933, 165 I.N.T.S. 19, Art. 1.

6 The Island of Palmas Case (or Miangas), United States of America v. the Netherlands. Award of the Tribunal of 4 April 1928, Reports of International Arbitral Awards. Vol. XI, The Hague. April 4, 1928 (reprint: The Hague. 2009), p. 838.

7 R. Kwiecień, Teoria i filozofia prawa międzynarodowego. Problemy wybrane, Wydawnictwo Difin, Warszawa 2011, p. 123.

8 Arbitration Commission of the Conference on Yugoslavia on 29 November 1991, Opinion no. 1, reproduced in 92 International Law Reports, 1993, point 1, 2.

9 R. D. Sloane, The Changing Face of Recognition in International Law: A Case Study of Tibet, "Emory International Law Review" no. 16, 2002, p. 116.

10 M. Muszkat (ed.), Zarys prawa międzynarodowego, Vol. II, Wydawnictwo Prawnicze, Warsaw 1956, p. 6. 
Until the end of the $18^{\text {th }}$ century, there were no references to state recognition in international law, and hardly any in international law studies. When the recognition became a topic of interest of theoreticians in the second half of the $18^{\text {th }}$ century, it was treated as an illegal intervention in matters of another state or as a unilateral act the need for which could not be justified. ${ }^{11}$ Only the events which led to the declaration of independence by states in American continents made members of the international community realize the role of state recognition. According to the concept of Lassa Oppenheim, international law is the law of civilized countries, and the recognition leads to the incorporation of a new state, created in accordance to the will of its nation, to the international community. In consequence, in the opinion of Oppenheim, the lack of recognition makes it impossible for a country to become a part of the family of civilized nations and to function in the international arena.

Taking the above into consideration, it became necessary to specify the criteria determining the formal acceptance of newly created states. For the first time, conditions for recognizing a state were determined in 1825 by the then Foreign Minister of the United Kingdom George Canning. Only a state, whose government had declared its independence and exercised the actual authority of the state, and which was stable, unified and banned slave trade, could hope to be recognized. ${ }^{12}$ Due to the territorial changes which took place in Europe after 1989 and to the necessity to harmonize the recognition criteria and adjust them

11 Such an opinion was expressed, inter alia, by Johann Christian Wilhelm von Steck and Georg Friedrich von Martens: J. Ch. Von Steck, Versuche über verschiedene Materien politischer und rechtlischer Kenntnisse, Lange1, Berlin-Stralsund 1783, available at http:// www.archive.org, accessed 16 Janury. 2016; G. F. von Martens, A Compendium of the Law of Nations founded on the treaties and customs of the modern nations of Europe, Cobbett and Morgan, London 1802, available at http://www.archive.org, accessed 16 January 2016.

12 R. Bierzanek, J. Symonides, Prawo międzynarodowe publiczne, Wydawnictwo PWN, Warszawa 1994, p. 134; More: on the concept of State recognition in the $19^{\text {th }}$ century: M. Fabry, Recognizing States. International Society and the Establishment of New States Since 1776, Oxford University Press, Oxford - New York 2010, pp. 49-78. It has not only been the recognition of a State that causes emotional reactions. The recognition of governments which came to power in a non-constitutional manner is equally controversial. In 1951, UK Foreign Minister Herbert Morrison, in his speech to the House of Commons, indicated criteria on the basis of which recognition of governments was to be performed. They included, inter alia, exercising actual and permanent control over most of the State territory. However, in 1980, Lord Carrington - another UK Foreign Minister - clearly stated that British authorities would not recognise governments. Thus, the UK accepted the Estrada Doctrine, elaborated earlier by authorities 
to the requirements of modern times, on December, $16^{\text {th }} 1991$ Foreign Ministers of Member States of European Communities adopted, at their meeting in Brussels, the Declaration on the Guidelines on the Recognition of the New States in Eastern Europe and in the Soviet Union. The Declaration comprised conditions which had to be met in order to make it possible to recognize a state. They included obligations to:

- respect the provisions of the Charter of the United Nations, the Final Act of the CSCE and the Charter of Paris for a New Europe;

- guarantee the rights of ethnic and national groups and minorities in accordance with the commitments subscribed to in the framework of the CSCE;

- respect the inviolability of all frontiers which can only be changed by peaceful means and by common agreement;

- accept all relevant commitments with regard to disarmament and nuclear nonproliferation as well as to security and regional stability;

- peacefully settle disputes, including disputes related to succession. ${ }^{13}$

Representatives of Member States of the then Communities highlighted that they would not recognize entities created as a result of aggression. Furthermore, they emphasized that, before making the final decision, they would take consequences for neighboring countries into account. The above criteria reflect not only the principles of international law (the obligation to solve disputes in a peaceful manner, the principle of the inviolability of frontiers) constituting its foundation but also the ius cogens norms (protection of human rights, respect for the principle of sovereign equality of States, prohibition of the use of force or threats to use force). ${ }^{14}$

Despite the elaboration of the criteria for recognition of new states, it is not absolutely clear if territorial changes have been consistent with applicable legal

of Mexico, which rejects the possibility of recognizing governments. More in D. H. Ott, Public International Law in the Modern World, London 1987, pp. 85, 88-89.

13 Declaration on the Guidelines on the Recognition of the New States in Eastern Europe and in the Soviet Union, Letter dated 17 December 1991 from the Permanent Representative of the Netherlands to the United Nations addressed to the Secretary-General. A/46/804, 18 December 1991.

14 That is the reason why Ch. Hillgruber was not right when he denied the relationship between the criteria elaborated within the framework of European Communities and the principles of international law. Cf. Ch. Hillgruber, The Admission of New States to International Community, "European Journal of International Law" no. 9, 1998, pp. 492-493. 
norms. Two, often contradictory, principles of international law are "weighed": sovereign equality of states (respect for the territorial integrity of a state) and the nations' right to self-determination. Sovereignty is a basic attribute of a state. It is defined as the absolute, sole, highest and unlimited authority of a state over its territory and population living there, and its capacity to act independently in the international arena. Sovereignty is important from the perspective of new state entities which strive for international recognition and, as a consequence, have to demonstrate the independent character of their actions at the internal and external levels. Above all, however, sovereignty is an argument used by states to protect their territorial integrity. It constitutes a specific protection against attempts at secession on the part of national and ethnic minorities living in the existing states. Thus, the sovereignty of existing states makes it difficult or even impossible for new state entities to declare independence.

The peoples' right to self-determination became an issue of interest to the international community during the French and the American Revolutions, when the right of a nation to decide about its own fate was emphasized. In the second half of the $19^{\text {th }}$ century, national awareness kept growing and thus attention started to be paid to nations' right to self-determination. In 1851, Pasquale S. Mancini, in his lecture entitled Nationality as the Foundation of the Law of Nations, presented his concept of rights attributed to a nation. He defined nationality as the right of an individual and a collectivity to benefit from freedom. As for freedom, he understood it as, inter alia, the right to create a separate state, to choose its internal regime, and to be independent from other peoples..$^{15}$ After World War I, the reference to the existence of the principle of nation's right to self-determination facilitated the acceptance of the new states emerging in territories of defeated countries. Self-determination, treated as a political but not legal principle, made it possible to achieve temporary political goals. It was American President Woodrow Wilson who argued for the recognition of the right to self-determination as a principle of international law. In his numerous speeches, he pointed out that every authority owed its powers to the will of those who were subject to the power, and each nation had the right to choose the authority it would be subject to. In his speech of January $8^{\text {th }}, 1918$, Wilson argued that national aspirations should be taken into account and the principle of the right to self-determination should be a norm in the international arena. He said that Russia should obtain "her an unhampered and unembarrassed opportunity for the independent determination

15 L. Dembiński, Samostanowienie w prawie i praktyce ONZ, Wydawnictwo PWN, Warszawa 1969, p. 12. 
of' her own political development and national policy;" the peoples of AustriaHungary "should be accorded the freest opportunity to autonomous development;" nations functioning under the Turkish regime rule "should be assured [...] an absolutely unmolested opportunity of autonomous development;" and the Polish nation should live in an independent Polish state. During the Versailles Peace Conference, Wilson underlined that it should be a basic rule in the postwar world that no government or group of governments should be allowed to force free nations to subordination. ${ }^{16}$ He postulated to add to the Covenant of the League of Nations, next to the guarantee of political independence and territorial integrity of states, the possibility of territorial transformations in order to execute the principle of self-determination. Possible territorial transformations would be an effect of changes in racial, social or political relations taking place within the population living in a contentious territory and causing an increase in independence aspirations among the population members. Territorial changes would take place also with the approval of $3 / 4$ of delegates of the League of Nations acting in the name and on behalf of the interested population. ${ }^{17}$ The ideas of Woodrow Wilson were developed further by Lloyd George who proposed to cover African nations living in German colonies with the principle of self-determination but those postulates did not gain international support. According to the Covenant of the League of Nations self-determination might take place only by means of granting nations autonomy within the framework of an existing state,$^{18}$ not by recognizing the right of nations to freely determine their political status. That is why, in the interwar period, self-determination functioned as a political principle. The opinion on Aland Islands of the Advisory Committee of jurists appointed by the League of Nations in 1921 confirmed that self-determination was only a political concept, not a principle of international law. ${ }^{19}$

For the first time the principle of self-determination entered international law at the end of World War II. The Atlantic Charter signed in 1941 did not mention

16 Cited after: A. Rigo Sureda, The Evolution of the Right of Self-Determination. A Study of United Nations Practice, Sijthoff International Publishing, Leyden 1973, pp. 95-96.

17 M. Pomerance, Self-Determination in Law and Practice. The New Doctrine in the United Nations, Springer, New York 1982, p. 7.

18 L. Dembiński, Samostanowienie w prawie...op.cit., p. 17.

19 J. Tyranowski, Integralność terytorialna, nienaruszalność granic i samostanowienie $w$ prawie międzynarodowym, Wydawnictwo PWN, Warsaw 1990, pp. 187-188; Ö. Österud, Sovereign Statehood and National Self-Determination. A World Order Dilemma, in: Subduing sovereignty. Sovereignty and the right to intervene, M. Heiberg (ed.), Pinter Publishers Ltd., London 1994, p. 23. 
the principle of self-determination in an explicit manner. However, the principle was referred to, as it was stated that the signatories of the Charter "desire to see no territorial changes that do not accord with the freely expressed wishes of the peoples concerned" and that "they respect the right of all peoples to choose the form of Government under which they will live; and they wish to see sovereign rights and self-government restored to those who have been forcibly deprived of them."20 The first international document in which self-determination was expressly mentioned was the Charter of the United Nations. In Article 1(2) it was stipulated that friendly relations among nations should be developed with respect for the principle of equal rights and self-determination of peoples. It was highlighted that only respect for the principle of equal rights and self-determination of peoples would allow to create conditions of stability and well-being necessary for the maintenance of peaceful and friendly relations among nations (Art. 55). The principle of self-determination was defined on 14 December 1960 in the Declaration on the Granting of Independence to Colonial Countries and Peoples (Resolution 1514 $\mathrm{XV})$. The emphasis on the inevitability of the process of decolonization guaranteed the people' right to self-determination. Self-determination was defined as the right to freely determine the political status and ensure economic, social and cultural development. The right to self-determination was attributed, under point 3 of the Declaration, regardless of the level of political, economic, social or educational development of the peoples. On 14 December 1960, Resolution 1541 (XV) was adopted. It determined the ways to exercise the right to self-determination. Under provisions of the Resolution, exercising its right to self-determination people may create their own independent state, associate with an existing state or decide on integration with another state. In each case, the decision on the future political status should be the result of a free and voluntary decision of people living in a given territory, of their will expressed in a democratic manner. ${ }^{21}$

In thus defined right to self-determination, its two perspectives need to be underlined. From the internal perspective, the right to self-determination is understood as the possibility to determine the form of government. From the external perspective, people have the right to freely determine a political status of their

20 Atlantic Charter of August 14, 1941, Art. 2, 3, available at http://avalon.law.yale.edu/ wwii/atlantic.asp, accessed 14 February 2016.

21 A. Potyrała, Prawo do samostanowienia a problem suwerenności państwa, in: Zbrojne konflikty $i$ spory międzynarodowe u progu XXI wieku. Analiza problemów i studia przypadków W. Malendowski (ed.), Wydawnictwo Atla 2, Wrocław 2003, pp. 76-80; M. Perkowski, Samostanowienie narodów w prawie międzynarodowym, Wydawnictwo PWN, Warsaw 2001. 
state. The latter arose most controversies. Pursuant to Resolution 1541 (XV), the political status may be determined in three ways. A nation (people) invoking the right to self-determination may decide for a creation of its own independent state, an association with an existing state or a separation from an existing state and integration with another state. These three ways for exercising the right to self-determination did not arise serious concerns in relation to colonial peoples. However, applying them to all nations could threaten the sovereignty of existing states and the international order. The international community noticed that the right to self-determination as a universal law could lead to an intensification of separatist movements among peoples invoking the right to self-determination. Therefore, in the Declaration on Principles of International Law of 1970 it was underlined that the peoples' right to self-determination should not be understood as "authorizing or encouraging any action which would dismember or impair totally or in part, the territorial integrity or political unity of sovereign and independent States conducting themselves in compliance with the principle of equal rights and self-determination of peoples" (Declaration 1970). Thus, the right to self-determination could be defined only as a right of peoples to demand and to develop autonomy within the framework of an existing state, the territory of which is inhabited by a given national group. It was decided that people could not invoke the right to self-determination by presenting demands for independence if a state acted in accordance with the principle of equal rights and self-determination of peoples. Thus, the interpretation of the right to self-determination as a right to secession $^{22}$ of national groups from the authority of existing states was expressly rejected. Secession is acceptable only in the case of serious and massive human rights violations. Such a view was earlier presented by Hugo Grotius and Emmer de Vattel. Thus, members of the international community had no doubts when inhabitants of Timor-Leste, Montenegro and Southern Sudan invoked the right to self-determination and chose independence in referendums. In these cases, the recognition of new countries was a natural consequence of acceptance of the peoples' right to self-determination. However, the chance that a given state or territory will gain international recognition is increasingly determined by political considerations or objectives. The reason is that the recognition of a state is not conditioned by law but by politics. ${ }^{23}$

22 L. C. Buchheit, Secession. The Legitimacy of Self-Determination, Yale University Press, New Haven-London 1978, pp. 43-137.

23 R. Rich, Recognition of States: the Collapse of Yugoslavia and the Soviet Union, "European Journal of International Law” no. 4, 1993, p. 36. 


\section{IS Proclaimed Statehood - IL Criteria and International Response}

Taking the above into consideration, it is necessary to refer the criteria constituting a state in international law and international relations to the so-called Islamic State (Islamic State of Iraq and the Levant, the Islamic State of Iraq and Syria, the Islamic State of Iraq and Sham, or Daesh).

Although the group controls a significant territory in Iraq and Syria and aspire to control the Levant region (which includes Iraq, Israel, Jordan, Lebanon and Syria), its leadership is effective and dominates over population inhabiting the territories, these facts cannot be regarded as the fulfillment of international law criteria for being a state. First of all, because there is no sovereignty, either in internal and external sense: the authority is not unlimited and independent from external factors. Secondly, because IS lacks capacity to enter into official international relations with members of the international community. As it was stated in the first part, the five criteria defined in international law must be supplemented by the one, perceptible in international practice, which is recognition. This is the final argument why IS cannot be regarded as a state. After the caliphate has been proclaimed, it met with no positive reaction of international community members who officially refused to accept the announcement. The basis for such decisions is a claim that no entity established as a result of the ius cogens norms violations can be recognized as a legitimate member of the international community. Accordingly, if a new entity claiming statehood strives for recognition, it must prove its readiness for compliance with international law. Otherwise, it has no chance of being accepted and consequently - no chance of being capable to enter into relations with other states, international organizations, etc. Taking into account that territorial integrity and internationally recognized borders of two states, Iraq and Syria, have been violated as a result of IS offensive, it would be illegal to establish any relations with this entity. Moreover, the IS's terrorist activities violate internationally accepted human rights, especially provisions prohibiting genocide, crimes against humanity, tortures and other cruel, inhuman treatment. Therefore, any attempt to enter into relations with this entity would be regarded as approval of international crimes.

While analyzing official documents issued by states and international governmental organizations, one can notice that in none there are references defining IS as a state. The only qualification of IS is an "entity" and a "terrorist group" or "organization", being a clear proof of lack of consent for the IS statehood and lack of approval of the IS's proclamation of caliphate.

The UN Security Council, responsible for international peace and security, has tackled the problem of IS functioning and its activities several times. In resolution 
2170 of August 2014 and 2253 of December 2015, pointing out "violent, extremist ideology", "widespread abuses of human rights and violations of international humanitarian law", "ongoing, multiple criminal terrorist acts" such as among others kidnapping and hostage-takings, the Security Council defined IS as a "splinter group of Al Qaeda"24. In the resolution 2178 of September 2014, while referring to IS, the official term "entity" was introduced by the Security Council ${ }^{25}$. In the resolution 2199 of February 2015, the Security Council confirmed "sovereignty, unity and territorial integrity" of Iraq and Syria, refusing to accept conquest as a way of acquiring territory by IS. ${ }^{26}$ Consequently, one of main attributes of statehood has been questioned.

A very similar position has been taken by the European Union. In conclusions adopted as a result of a special meeting of the European Council in August 2014, the qualification of IS as a "terrorist organization" has been made. ${ }^{27}$ The creation of the Islamic Caliphate in Iraq and Syria has been regarded as "a direct threat to the security." ${ }^{\prime 2}$ Such official statement has been repeated in the following conclusions, agreed on as a result of the Council of the European Union meetings in October 2014 and March 2015. The EU decided to condemn acts perpetrated by "ISIL/ Daesh and other terrorist groups" and announced its contribution to the international endeavour to defeat these entities. ${ }^{29}$ In the same documents, references to IS as to a "terrorist organization" have been made. ${ }^{30}$ In the regional strategy for Syria and Iraq, adopted by the Council of the European Union in March 2015, there are no references to IS statehood. Instead, the group is called "a cross-border

24 Resolution 2170 Adopted by the Security Council at its $7242^{\text {nd }}$ meeting, on 15 August 2014. S/RES/2170 2014, para. 1, 18, preamble; Resolution 2253 (2015) Adopted by the Security Council at its 7587 th meeting, on 17 December 2015., S/RES/2253 2015, preamble.

25 Resolution 2178 (2014) Adopted by the Security Council at its $7272^{\text {nd }}$ meeting, on 24 September 2014, S/RES/2178 2014, preamble.

26 Resolution 2199 Adopted by the Security Council at its $7379^{\text {th }}$ meeting, on 12 February 2015, S/RES/2199 2015, preamble.

27 Conclusions, Special meeting of the European Council (30 August 2014), EUCO 163/14, Brussels 2014, para. 14, 17.

28 Ibid. para. 17.

29 Council conclusions on the EU Regional Strategy for Syria and Iraq as well as the ISIL/ Da'esh threat, Council of the European Union, Brussels, 16 March 2015, 7267/15 Brussels, para. 1, 2, 13; Council conclusions on the ISIL/Da'esh crisis in Syria and Iraq, Council of the European Union, Luxemburg, 20 October 2014, para. 1, 3, 5.

30 Council conclusions on the EU Regional ... op.cit., para. 8; Council conclusions on the ISIL/Da'esh... op.cit., para. 7. 
phenomenon spanning two sovereign states" what is a clear evidence that military actions directed to acquisition of territory belonging to Syria and Iraq are not accepted by the EU member states. The European Parliament in its resolutions uses the term "the so-called "ISIS/Daesh"” and "the self-styled 'Islamic State" to deny IS statehood. ${ }^{31}$ At the same time, the character of "a terrorist group" or "a terrorist organization" is emphasized, and IS is described as an "extremist jihadist group."32

According to the League of Arab States, IS is an organization responsible for international crimes and terrorism. Similarly, the North Atlantic Treaty Organization defines IS as a "terrorist group" and an "organization", as does the Organization for Cooperation and Security in Europe. According to OCSE, Islamic State is "probably the most effective terrorist organization in using social media." 33 Such connotations are also noticeable in official statements of other international bodies such as non-governmental or organizations define IS as a terrorist group. According to the Institute for Economics and Peace, IS was "the most destructive terrorist group in 2014." ${ }^{34}$ The Global Coalition to counter the Daesh, announced in September 2014 by president Obama, composed of over 60 states, ${ }^{35}$ aimed at IS degradation and destruction "through a comprehensive and sustained counterterrorism strategy" regards IS as a "terrorist organization." For this reason, partners

31 See: European Parliament resolution of 4 February 2016 on the systematic mass murder of religious minorities by the so-called 'ISIS/Da'esh', European Parliament, 2016/2529(RSP), P8_TA-PROV(2016)0051, Strasbourg 2016, para. 1, 2, 4, 7-9, 14; European Parliament resolution on the situation in Iraq and Syria and the ISIS offensive, European Parliament, 2014/2843(RSP), B8-0110/2014, Strasbourg 2014, summary.

32 European Parliament resolution on the situation in Iraq and Syria and the ISIS offensive ...op.cit., preamble, point A.; ISIL/Da'esh and 'non-conventional' weapons of terror, Briefing 2015. 572.806, European Parliamentary Research Service.

33 Organization for Security and Cooperation in Europe (OSCE) Human Dimension Implementation Meeting (HDIM), European Foundation for Democracy, HDIM. NGO/0025/15, 22.09.2015, p. 2.

34 Global Terrorism Index, Measuring and Understanding The Impact of Terrorism, Institute for Economics and Peace, New York-Sydney-Mexico 2015, p. 38.

35 Afghanistan, Albania, Australia, Austria, Bahrain, Belgium, Bosnia and Herzegovina, Bulgaria, Canada, Croatia, Cyprus, Czech Republic, Denmark, Egypt, Estonia, Finland, France, Georgia, Germany, Greece, Hungary, Iceland, Iraq, Ireland, Italy, Japan, Jordan, Korea, Kosovo, Kuwait, Latvia, Lebanon, Lithuania, Luxembourg, Macedonia, Malaysia, Moldova, Montenegro, Morocco, Netherlands, New Zealand, Nigeria, Norway, Oman, Panama, Poland, Portugal, Qatar, Romania, Saudi Arabia, Serbia, Singapore, Slovakia, Slovenia, Somalia, Spain, Sweden, Taiwan, Tunisia, Turkey, Ukraine, United Arab Emirates, United Kingdom, United States. Additionally, Arab League and European Union. 
have decided about targeting IS with airstrikes, impeding the flow of foreign fighters and disrupting the recruitment, as well as stopping IS's financing and funding.

\section{Conclusion}

The rise of Islamic State and the official proclamation of a caliphate, has started discussions concerning an official status of IS in international law and international relations. Two groups of arguments - legal and practical - have been taken into consideration by states, international governmental organizations, as well as think tanks and NGOs. After the analysis of six criteria of statehood, as well as reactions of the international community members, the only possible conclusion is that because of the illegal character of IS's activities, lack of full independence and resistance of the international community members, especially states and governmental organizations, it is not possible to treat IS as a state being a legitimate actor in the international arena. Not only decisions concerning non-recognition of IS statehood have been taken, but also an international coalition has been created with the aim to counter IS, being a clear proof that IS is nothing but a "terrorist organization" or "group."

\section{References}

Arbitration Commission of the Conference on Yugoslavia on 29 November 1991, Opinion no. 1, reproduced in 92 International Law Reports, 1993.

Atlantic Charter of August 14, 1941, available at http://avalon.law.yale.edu/wwii/ atlantic.asp, accessed 14 February 2016.

R. Bierzanek, J. Symonides, Prawo międzynarodowe publiczne, Wydawnictwo PWN, Warszawa 1994.

L. C. Buchheit, Secession. The Legitimacy of Self-Determination, Yale University Press, New Haven-London 1978.

Conclusions, Special meeting of the European Council (30 August 2014), EUCO 163/14, Brussels 2014.

Council conclusions on the EU Regional Strategy for Syria and Iraq as well as the ISIL/Da'esh threat, Council of the European Union, Brussels 16 March 2015, 7267/15.

Council conclusions on the ISIL/Da'esh crisis in Syria and Iraq, Council of the European Union, Luxemburg, 20 October 2014.

J. R. Crawford, The Creation of State in International Law, Oxford University Press, Oxford 1979. 
Declaration on the Guidelines on the Recognition of the New States in Eastern Europe and in the Soviet Union, Letter dated 17 December 1991 from the Permanent Representative of the Netherlands to the United Nations addressed to the Secretary-General. A/46/804, 18 December 1991.

L. Dembiński, Samostanowienie w prawie i praktyce ONZ, Wydawnictwo PWN, Warszawa 1969.

M. Dixon, Textbook on International Law, Oxford University Press, Oxford 2013. ISIL/Da'esh and 'non-conventional' weapons of terror, Briefing 2015. 572.806, European Parliamentary Research Service.

European Parliament resolution of 4 February 2016 on the systematic mass murder of religious minorities by the so-called 'ISIS/Da'esh', European Parliament, 2016/2529(RSP), 2016. P8_TA-PROV(2016)0051, Strasbourg 2016.

European Parliament resolution on the situation in Iraq and Syria and the ISIS offensive, European Parliament, 2014/2843(RSP), B8-0110/2014, Strasbourg 2014.

M. Fabry, Recognizing States. International Society and the Establishment of New States Since 1776, Oxford University Press, Oxford and New York 2010.

Global Terrorism Index, Measuring and Understanding The Impact of Terrorism, Institute for Economics and Peace, New York-Sydney-Mexico 2015.

Th. Grant, Defining Statehood: The Montevideo Convention and its Discontents, "Columbia Journal of Transnational Law" no. 37, 1999, pp. 403-457.

D. H. Ott, Public International Law in the Modern World, London 1987.

Ch. Hillgruber, The Admission of New States to International Community, "European Journal of International Law" no. 9, 1998.

H. Kelsen, The Pure Theory of Law and Analytical Jurisprudence, "Harvard Law Review" no. 55, 1941, pp. 44-70.

R. Kwiecień, Teoria i filozofia prawa międzynarodowego. Problemy wybrane, Wydawnictwo Difin, Warszawa 2011.

G. F. von Martens, A Compendium of the Law of Nations founded on the treaties and customs of the modern nations of Europe, Cobbett and Morgan, London 1802, available at http://www.archive.org, accessed 16 January 2016.

Montevideo Convention on the Rights and Duties of States, 1933, 165 I.N.T.S. 19.

M. Muszkat (ed.), Zarys prawa międzynarodowego, Vol. II, Wydawnictwo Prawnicze, Warsaw 1956.

Ö. Österud, Sovereign Statehood and National Self-Determination. A World Order Dilemma, in: Subduing sovereignty. Sovereignty and the right to intervene, M. Heiberg (ed.), Pinter Publishers Ltd., London 1994, pp. 18-32. 
Organization for Security and Cooperation in Europe (OSCE), Human Dimension Implementation Meeting (HDIM), European Foundation for Democracy, HDIM.NGO/0025/15, 22.09.2015.

M. Perkowski, Samostanowienie narodów w prawie międzynarodowym, Wydawnictwo PWN, Warsaw 2001.

M. Pomerance, Self-Determination in Law and Practice. The New Doctrine in the United Nations, Springer, New York, 1982.

A. Potyrała, Prawo do samostanowienia a problem suwerenności państwa, in: Zbrojne konflikty i spory międzynarodowe u progu XXI wieku. Analiza problemów i studia przypadków W. Malendowski (ed.), Wydawnictwo Atla 2, Wrocław 2003, pp. 73-96.

Resolution 2170 Adopted by the Security Council at its $7242^{\text {nd }}$ meeting, on 15 August 2014. S/RES/2170 (2014).

Resolution 2178 Adopted by the Security Council at its $7272^{\text {nd }}$ meeting, on 24 September 2014, S/RES/2178 (2014).

Resolution 2199 Adopted by the Security Council at its $7379^{\text {th }}$ meeting, on 12 February 2015, S/RES/2199 (2015).

Resolution 2253 Adopted by the Security Council at its $7587^{\text {th }}$ meeting, on $17 \mathrm{De}$ cember 2015, S/RES/2253 (2015).

R. Rich, Recognition of States: the Collapse of Yugoslavia and the Soviet Union, "European Journal of International Law" no. 4, 1993, pp. 36-65.

A. Rigo Sureda, The Evolution of the Right of Self-Determination. A Study of United Nations Practice, Sijthoff International Publishing, Leyden 1973.

R. D. Sloane, The Changing Face of Recognition in International Law: A Case Study of Tibet, "Emory International Law Review" no. 16, 2002.

J. Ch. Von Steck, Versuche über verschiedene Materien politischer und rechtlischer Kenntnisse, Lange 1, Berlin-Stralsund 1783, available at http://www.archive. org, accessed 16 January 2016.

US Department of State, The Global Coalition to Counter ISIL, 2014, available at http://www.state.gov/s/seci, accessed 21 February 2016.

The Island of Palmas Case (or Miangas), United States of America v. the Netherlands. Award of the Tribunal of 4 April 1928, Reports of International Arbitral Awards. Vol. XI, The Hague, April 4, 1928 (reprint: The Hague 2009).

J. Tyranowski, Integralność terytorialna, nienaruszalność granic i samostanowienie w prawie międzynarodowym, Wydawnictwo PWN, Warsaw 1990. 



\section{Hallar Abderrahaman Mohamed \\ Woman and ISIS: \\ Social Diagnosis and Interventions}

\section{Introduction}

The question of the so-called global terrorism is an essentially historical, social, and political phenomenon, although the present article applies an approach based on a social and psychological perspective focused on individuals. One of the key aspects to consider in this analysis of global terrorism is that it comes from a manipulated interpretation of the Quran. Jihadist terrorists intend to create a single Muslim state and to eradicate any form of thinking and living that is different from their precepts. Their target are all non-Muslim people as well as Muslims who do not think like they do. They constitute a terrorist organization that is expanding by virtue of the global access to recruiting young people. They use social networks, new technologies and any other public space, mosques, neighborhoods and associations bringing young people together, to capture new recruits willing to join their cause.

The present flow of Western fighters departing for Syria and Iraq is one of the biggest problems for Western governments because it poses a great threat. Governments face the challenge of designing strategies to control the growth of this phenomenon and to stop the radicalization processes here, in Western Europe. That is the reason why it is necessary to understand and learn in depth how jihadism is penetrating into our society.

Men constitute the central core of the terrorist group. They are given the most important and cruelest tasks in the jihadist fight, such us kidnappings, decapitations or immolations. However, we observe a significant increase in the number of women joining in combat, which accompanies a lack of information on the role they play within the Daesh.

Historically, although they have participated in violent conflicts around the world, the role of women has always been related to domestic tasks. Traditionally, the role of women in the Daesh was limited to assisting fighters in their needs, to educate their children - who would be future fighters - and to taking care of their homes. They are also used as a tool to attract more fighters, and there are records of real cases in which they have participated in terrorist acts.

The gradual incorporation of women to fight in support of the Daesh is a reason for great concern. From an analysis of the multiple discriminations suffered by 
women (especially of Arab descent) in the world because of their race, religion and their status as women, it is observed that this incorporation does not respond to a process of equality between men and women, Rather, women are used as weapons, which is a form of exploitation and perpetuation of their traditional roles.

Strategies to prevent and block jihadist terrorism need to be designed. This implies the incorporation of disciplines such as social work and other social and legal sciences. The starting point needs to be an analysis of radical and terrorist violence aiming to apply theoretical information to the practical field and to work on the people, families, groups, and communities adding synergies to the fight against radicalism.

The aim of this paper is to expound the elements that lead women to make incursions into the current terrorism which is preached by the Daesh. ${ }^{1}$ What are the motivations to commit barbarous acts and what kind of processes of manipulation are used to achieve these ends are questions that remain without answers. This paper tries to analyze the possible motivations of women and, at the same time, to examine the role they play inside these terrorist organizations. In short, the aim of this investigation is to get closer to the answers to many emerging questions about women's migration to become part of Daesh, and to create efficient measures, starting with an intervention of social work to prevent radicalism which is the main source of this phenomenon.

\section{Islam and Muslim Women}

The Quranic revelation brought real changes to women's way of life in Arabia, as it started a dynamic liberalization of women, anchored up until that moment in a strictly patriarchal regime. Before the arrival of Islam, the birth of a baby girl was considered a disgrace and even a shame in Arabia. Terrible facts such as burying them alive by the parents might occur, as they were considered a threat to the family's honor:

And when one of them is informed of [the birth of] a female, his face becomes dark, and he suppresses grief. He hides himself from the people because of the ill of which he has been informed. Should he keep it in humiliation or bury it in the ground? Unquestionably, evil is what they decide (Quran 16:58-59). ${ }^{2}$

1 Name received by the self-proclaimed Islamic State, Daesh, in plural dawaesh, means fanatics imposing their point of view on the others.

2 The noble Quran, And when one of them is informed of [the birth of] a female, his face becomes dark, and he suppresses grief, He hides himself from the people because of the ill of which he has been informed. Should he keep it in humiliation or bury it in the ground? 
Adult women were considered sexual objects that could be bought, sold and inherited, ignoring their qualities, their intellectual and personal abilities and reducing them to mere instruments for men's sexual pleasure.

It was even questioned whether women were humans or if they had a soul. However, Islam provided this oppressed sector of society with a legitimate place in life. From a position of inferiority and legal incapacity, Islam put women in a position of great influence and prestige within family and society. Islam proclaims: O mankind, indeed we have created you from male and female (Quran 49:13). ${ }^{3}$

O mankind, fear your Lord, who created you from one soul and created from it its mate and dispersed from both of them many men and women. And fear Allah, through whom you ask one another, and the wombs. Indeed Allah is ever, over you, an Observer (Quran 4:1). ${ }^{4}$

Men and women are from the same family, and as such, they have the same rights and duties as promised by Allah: "Never will I allow to be lost the work of [any] worker among you, whether male or female; you are of one another" (Quran 3:195). ${ }^{5}$ The arrival of Islam meant an important change regarding the privation of basic and fundamental needs that were provided to women by society. There was an evolution leading to involve women in the society at the time. Tribal laws were transgressed and women tried to end their humiliating ancestral habits. They collaborated arm in arm with the new community; women reclaimed their rights and participated in every political act of the time.

Clear examples of evolution, participation and influence are those of Jadiyya, A'isha (wives of the prophet Mohammed) and Rabi'a al-Basri (the notable Sufi woman), who occupied significant positions at the beginning of Islam. A'isha, the prophet's wife, was a cultured, distinguished woman who transmitted her knowledge, her wisdom and her political sense to generations of Muslim wise men. She lived for a long time after the death of the prophet, and her house was like a

Unquestionably, evil is what they decide, available at http://quran.com/16/58-59, accessed 4 January 2016.

3 The noble Quran, O you who have believed, do not put [yourselves] before Allah and His Messenger but fear Allah. Indeed, Allah is Hearing and Knowing, available at http:// quran.com/49, accessed 4 January 2016.

4 The noble Quran, O mankind, fear your Lord, who created you from one soul and created from it its mate and dispersed from both of them many men and women. And fear Allah, through whom you ask one another, and the wombs. Indeed Allah is ever, over you, an Observer, available at http://quran.com/4, accessed 4 January 2016.

5 The noble Quran, Alif, Lam, Meem, available at http://quran.com/3, accessed 4 January 2016. 
reference centre in the religious sciences. She was an authority herself and came to occupy an important place in society. Visitors came from all over the Islamic world to ask her and follow her advice. No fact of Islamic history could be valid if she would not approve it. At the age of 42 , she led an army onto the battlefield. ${ }^{6}$

We can affirm that Islam recognizes women's rights to participate in politics, to occupy public positions and to take part in legitimate debates, to fraternize and to exercise any profession that can be executed by men. But as time went by, and as Islam spread across the whole territory, the interpretations that arose by the mediation of the imams deteriorated women's position and manipulated the original message, according to patriarchal interest, in order to create the Islamic society on a rigid, patriarchal base.

\section{Gender Stereotypes}

The present phenomenon of women joining up with the self-proclaimed Islamic State has grown to thousands, including more than a hundred women of European descent. The interest of the scientific community and the society in general to learn about the role played by these women and why they are joining the terrorist fight has increased.

To be able to understand the role of women in the Daesh, we need to make an overall analysis of what are the gender stereotypes, what features do they lend to women in general, and to female terrorists in particular. By this we mean the group of existing beliefs considered as adequate features of men and women, placing women in the private sphere dedicated to their homes and children, while men occupy the public sphere. The stereotypical personality traits associated to women find them tender, compassionate, sensitive to necessities, loving and submissive, and those who cry easily; whereas the traits associated to masculinity are leadership, love for risk, individualism, aggression, strong personality, athleticism, selfishness and toughness. These characteristics strongly match what must be an authentic terrorist which were lacking in women. ${ }^{7}$

The same stereotypes are revealed and perpetuated in the militant leaders' argument on the role of women in conflicts. This drives the myth which translates into a belief that women are not political; as a consequence, the tasks of man and women are divided according to physical differences between them, which

6 H. Padilla, La mujer en el islam, feminismo islámico, Centro de Estudios Internacionales para el Desarrollo (CEID), Buenos Aires 2011.

7 M. Lopez, J. Morales and A. Lisbona, Evolution of Gender Stereotypes in Spain: Traits and Roles, “The Spanish Journal of Psychology" no. 11 2008, pp. 609-617. 
produces a belief in the capacity of one, and not the other group, to carry out certain acts. What is more, it is believed that the purpose and primary function of a woman is to be a mother and wife instead of having an identity. The same gender stereotypes are found at the root of the conventional wisdom that, even when it tends to ignore the role of women as central actors, is quite certain that women play support roles in favor of the terrorist groups, as it is understood that women are in a better position to provide and keep safe homes, to act as bait or to carry out surveillance tasks or be messengers. The gender stereotypes try to separate women from the conflict and keep the position of women as guardians of civil life, generating the extended belief that women only play support roles and are not main actors in the planning and execution of attacks.

An article published by the Institute el Cano about women and the so-called Islamic State reflects that the role reserved to women within Daesh has been very much discussed and shows the emergence of a feminine jihadist subculture which understands jihad as a holy war and in which women are given more operational functions, thereby overcoming the established gender clichés, supported in this regard by both the traditional Islamic sources and the Salafist ideology lead by Daesh. Even if it is true that in some very specific cases tasks given to women surpass the domestic environment, it is not less true that, until today, we have not been able to affirm that there is a real break with it.

To understand and learn about the gender stereotypes within Daesh, it is necessary to analyze the process of attraction, radicalization, and the role played by women within the organization where they are, once again, discriminated.

\section{The Role of Women in Daesh}

\subsection{Terrorist women profile}

The profile of these women constitutes a typological diversity causing an obstacle when establishing particular features in the case of religious ideology. They are young female converts or come from Muslim backgrounds, both practicing and non-practicing families, that in principle were not especially devoted to the Islamic religion in many cases. It would frequently happen that they would become radicalized after suffering traumas, or as a consequence of a subtle, skilled manipulation process by extremist groups.

Regarding education, broadly speaking, the educational level of women recruited is low or very low, covering only the most basic education. Except for a few of them having higher level studies, some of them reaching university level, the social groups to which they belong can be both rural or urban, middle class or disadvantaged so- 
cial and economic environments. This situation makes them much more vulnerable to suffer manipulation by insurgent groups, given their lack of culture and the fact that many of them had never left the confines of their small world. ${ }^{8}$

Several studies conclude that the age range of these women is generally between 15 and 35 years old and in most of the cases their civil situation is single in all countries.

In terms of social environment, the recruited girls may have worked in licit or illicit professions - sometimes both of them - and had unstructured or normalized lives, having solely a European social-cultural outlook, or this mixed with habits from the country of origin. The wide game of sociological features makes it impossible to determine a standard profile. ${ }^{9}$ But despite not having a standard profile, we can point to certain psychological and social vulnerabilities, used by radicals to guarantee that women join the terrorist war.

\subsection{Recruitment Process}

To explain the enormous attraction the new global terrorist matrix is causing among many Muslim women we need to underline the implementation of a recruitment campaign designed specifically for them. The efforts to recruit women to Daesh start with the identification of possible matches undergoing a moment of psychological and/or social weakness. Once the woman is located, the organization makes considerable effort to convince her that these kinds of actions contradict neither the Islamic principles nor the usual responsibilities of a Muslim woman, which is another clear example of manipulation.

Daesh, aware of the importance of recruiting young women, uses social networks like Twitter, Instagram, Facebook, YouTube, etc. to reach them. Knowing that the youngest of these women spend a lot of time on the Internet and it is an ideal space to take advantage of disaffection toward Western culture and, at the same time, increase the extreme identification with radical ideas.

8 A. Rubin, Woman says she told police about paris attacker's hide-out, "The New York Times" 2008, available at http://www.nytimes.com/2016/02/05/world/europe/womansays-she-told-police-about-paris-attackers-hide-out.html?ref=topics\&_r $=0$, accessed 6 January de 2016.

9 R. Torres, L. Ponce, Reislamización digital y yihadismo europeo: claves comprensivas para la intervención social comunitaria, "Sistema" no. 240, 2015, pp. 101-116. 
The Institute for Strategic Dialogue analyses the importance of the romance factor as one of the motivations that make young women join a terrorist group in the occupied territories. ${ }^{10}$

Up until 2012, female participation in such activities carried out in the Spanish territory was promoted mainly by the attraction of a male (relative or partner) and related to support tasks and housework (other tasks such as, legalizing the man's administrative situation), It was not related to the operative's activities in terrorist militancy. From 2013, in the context of conflict in Syria and Iraq, the situation has changed: the first cases of mobilized women - motivated by their partners and by themselves, after being recruited and radicalized normally through social networks connected to Daesh - were reported. According to the families' testimonies, most of the times they were seduced by a romantic vision of life in the Caliphate, while only a small proportion of them joined with the intention to form the first line of combat, something that, in the end, would not happen since the active practice of violence is very far from the Daesh idea of what the feminist jihad should be. ${ }^{11}$

In the recruitment process, women play a very important role of recruiting other women. As Ramachandran says, the terrorist groups have taken advantage of the "martyrdom" of female suicide bombers through an extended use of propaganda, getting more attention and publicity for their cause. The image of young women fighting desperately against the powerful (be it Israel, Russia or the USA) through the extreme practice of blowing themselves up has an immediate global effect. Even though the suicide attacks causes wide condemnation, the vision of a woman that sacrifices her life for the Palestinian cause defying traditions, draws the attention to the desperation an entire people. ${ }^{12}$

The Daesh recruitment networks do not miss out on the great capacity of women to spread propaganda and recruit new members through their profiles in social networks, where tales about the crisis in Western values can be found, as well as frustrations from the difficulties in practicing their religion in their countries of origin to the satisfaction of living alongside their "sisters" and "living honorably under Sharia law", spreading an idyllic vision of the life project

10 C. Garcia, Las Mujeres del Estado Islámico, Instituto Elcano 2001, available at http:// www.realinstitutoelcano.org/wps/portal/web/rielcano_es/contenido?WCM_GLOBAL_CONTEXT=/elcano/elcano_es/zonas_es/terrorismo+internacional/comentariogarciacalvo-las-mujeres-del-estado-islamico, accessed 5 January 2016.

11 Ibid.

12 S. Ramachandran, Women Suicide Bombers Defy Israel, "Asia Times", available at $w w w$. atimes.com/atimes/Middle-East/EJ25Ak02.html, accessed 2 January 2016. 
offered by Daesh, as documented by Carol Hoyle, Alexandra Bradford and Ross Frenett, in their empirical work "Becoming Mulan? Female Western Migrants to ISIS." The authors point out that these women support the brutal use of violence with the same intensity as their male companions and they manifest it as such in their social network profiles, even though only very few of them are interested in practicing it in an active way. ${ }^{13}$

\subsection{Motivations to participate}

The reasons why they travel are as varied as the women themselves. We could look at several reasons that motivate them to go; one of them is ideology - just as men, women are convinced that they would go straight to paradise if they die fighting for Islam. A new vision of Islam is presented to them in a very attractive manner, as the only way to bring themselves closer to God. Theocratic cosmopolitanism is another reason, most women express their deep grievances at the treatment of Muslims across the world, and deplore the West's foreign policy, they have feelings of hate for everything they consider foreign, and their only solution is an ideal Islamic society built on their strict interpretation of Islamic law where they can carry out their practice. The feelings of rejection from the society to which they belong but with which they do not identify, the search for an Islamic identity and the sense of unity and sisterhood are also key causal factors for women who travel. ${ }^{14}$

Lastly, one possible motivation is the women's demand for equality that they have not had in their place of origin. This struggle for equality is causing women to be used by certain groups and people with specific interests. It encourages them to give everything for this desired equality that many will probably never reach, no matter how many empty promises they receive or how much they try to convince them with acts of uncertain temporality. Sadly, the eagerness of these women to escape a life predestined to man's subordination and dedicated to the exercise of irrelevant and accessory social tasks, remains a failed attempt. It is clear that within these groups women are blatantly discriminated against, and that it is not even hidden in the public sphere.

13 C. Hoyle, A. Bradfor and R. Frenett, Becoming Mulan? Female Western Migrants to ISIS, Institute for Strategic Dialogue (ISD), 2015, available at http://www.strategicdialogue. org/publications/, accessed 4 January 2016.

14 Ibid. 


\section{Proposals for Prevention and Intervention in Radicalization}

\subsection{Social integration as prevention's key aspect}

Dealing with social integration requires working to make people feel like members of the society in which they live, with the ultimate aim to protect them from radical discourse and influence. It is about providing identity and a sense of belonging to the targeted population - especially the second or third generation of young people descended from migrants - and providing an answer to their aspirations which might otherwise be satisfied by the radicals.

To make integration possible, there are two conditions which need to be present: the social context has to be favorable to this integration, on the one hand and, on the other, people must be able to participate in the social, political, economic and cultural life of the society. Both are closely related in a way that, if people did not have the chance to develop their capabilities and abilities, they would not be able to take advantage of their chance to participate. Therefore, they must be offered the necessary opportunities, protecting the weak and recognizing the right to create, innovate and differ in opinion. The population needs to be prepared to live together, respecting everyone's dignity, prioritizing non-violence and solidarity.

It is necessary to take into account global systemic inequality when analyzing integration processes, to identify and recognize that Muslim and specifically migrant women do not hold the same rights and opportunities as the rest of the society. It is important to recognize the fact that their gender as well as their racial and religious origin deepen their exclusion and hinder their social inclusion.

One of the common characteristics of many women joining Daesh is that they do not feel like members of European society where they live. For them, the only community for reference is the one of Muslims in general and, particularly, the one of the Mujahidins fighting in Syria, Iraq, Afghanistan, etc. Working difficulties, family and social isolation, as well as the absence of opportunities and/or incapacity to apply the social rights and not participating in the social, cultural, economic and political life, make women contemplate the society and the country they live in as enemies. No doubt this affects their recruitment to extremism.

It is true that socio-political integration is not the final trigger in the process of radicalization and jihadist recruitment, but it is a factor to be taken into account since, in the long term, this lack of integration may become a key element for socially conflictive identity based on resistance. However, even though it is not a definitive factor, the existence of high levels of socio-political integration may serve as a radicalization brake and benefit from the management of social 
problems through peaceful and democratic channels. An effective combination of integration measures in the socio-economic and socio-political-cultural areas would contribute to preventing radicalism. ${ }^{15}$

Group empowerment, as a social intervention tool through women's associations or organizations, increases people's self-esteem, their personal networks and may become an adequate tool in combating the multiple inequalities that many women suffer. From the perspective of the community empowerment, bringing women together can foster social collaboration. Furthermore, the group empowerment is a fundamental instrument to fight against poverty and social inequality, to modify the social contexts in which the problematic situations are generated. ${ }^{16}$

There is no doubt that women's role in the Muslim world, and also in other cultures, is crucial when it comes to education based on a transmission of values and cultural references. From that perspective, women's empowerment would not only provide them the role they deserve as social actors, but also generate a collective profile that exerts positive leadership which would transform structures that sustain armed struggle and radicalism, and would allow developing different strategies oriented on the integration, development, and peaceful coexistence among cultures.

\subsection{The role of social work in radicalization prevention}

Social work is a profession based on practice and a social discipline that promotes change and social development, social cohesion, people strengthening and wellbeing. The principles of social justice are human rights, collective responsibility and respect for diversity. Backed by the social, human and cultural theories, social work requires both the subjects and structures to face problems, necessities and risks in a joint effort. ${ }^{17}$

The intervention in social work is understood as the action organized and developed by social workers with people, groups and communities, with the aim of generating changes that help satisfying their needs; overcoming physical and non-physical difficulties, social problems and obstacles that interfere or limit equal

15 M. Castells, La era de la información. Economía, Sociedad y Cultura. Volumen II: El poder de la identidad, Alianza Editorial, Madrid 1998.

16 M. Silvestre, R. Royo, E. Escudero, El empoderamiento de las mujeres como estrategia de intervención social, Universidad de Deusto, Bilbao, 2014.

17 Definition of social work adopted by the General Assembly of the International Federation of Social Workers, Montreal, Canada, July 2000. 
opportunities; increasing people's capacities; and, finally, contributing to promote social integration.

The social worker represents a fundamental bond that contributes in the organization and functioning of institutions and services for the population's integration and social wellbeing. As such, its role as a subject of this article becomes especially important.

The lack of knowledge and practical experience in the development of actions oriented on the intervention and prevention of radicalism requires expert debate by people who, understanding radical and polarized interpretations of Islam, are able to analyze and propose strategies that offer a framework to develop social intervention, from the viewpoint of investigation, prevention and awareness-raising.

There is no doubt that the social sciences play a fundamental role in the analysis and development of processes for the intervention and prevention of radicalism. There is a necessity to possess an integral and multidisciplinary vision on the subject to be able to face it and provide answers to the existing challenges. The intervention must contemplate three axes: prevention (to avoid the creation of conditions favoring the radicalization processes), signaling (of individuals in the process of becoming radicals or those promoting extremist ideas) and intervention in the detected cases.

Social work can contribute to modify the structural factors that explain radicalization through integration in the long term, intercultural dialogue and the fight against inequality and discrimination. To that end, there is a need to involve Muslim communities in the prevention and the fight against terrorism, generating a network that makes it harder to present the recruitment offer as attractive. Furthermore, this discipline can contribute to the socio-economic and socio-cultural integration of immigrants as they arrive, but even more so to their descendants, due to the importance of paying attention to second generations and how they integrate in society. The bet must be on a multicultural integrative model that respects and integrates the different cultures, and be proactive and propose alternatives to reach communities from community social work.

The message used by the recruitment networks could be neutralized by intercultural dialogue and promoting forums for debate, reflection and training, mainly in those places where people are brought together, with special attention on places like prisons, cyberspace or places dedicated to religious training or prayer. It would be necessary to prevent extremist messages from being disseminated, while, at the same time, generating alternative messages that build objective realities regarding the Quran and its interpretations. The voices of the majority must prevail over the voices of extremists. From that perspective, the work has to 
be carried out to promote a better knowledge of Islamic cultural values in Europe and improve the perception of Islamic cultures.

\subsection{Islamic feminism as a source for preventing radicalism}

The religious fundamentalisms stand for a global phenomenon that requires a global answer. The resistance offered by the activists of Islamic feminism and women rights can provide an answer by virtue of a diverse, transnational and consistent action.

Religious fundamentalism is by definition opposed to women's autonomy; the fundamentalists' projects operate by undermining women's rights as well as human rights in general and their development. Many young people have been exposed to a fundamentalist interpretation of religion and do not hold the critical resources to analyze radical messages. This can seriously impact women in that they may think and feel that they are not entitled to any rights at all, that others may influence their decisions regarding themselves, their minds and bodies, and even make these decisions for them. This involves accepting that they are second-

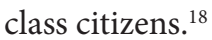

The role of Islamic feminist is crucial, since they are dedicated to combat any kind of violence, especially when it is carried out in the name of Islam, like violent extremism. The network of Muslim women fighting for peace declares: We, Muslim women, must reclaim the mantle of cultural, intellectual, and religious authority, declaring our opposition to violence with a powerful and unified voice. We must announce our Commitment to resisting injustice generally and violence specifically through peaceful means and from the unique perspective of women. We must speak comprehensively and holistically to a diversity of discourses to effectively oppose violence. ${ }^{19}$

They also express their jihad as fighting against violent radicalism, declaring their commitment to compassion, peace and social justice, just like the Islamic doctrine says, and aspiring to unite people to create harmony, cooperation and collective achievement and prosperity. At the same time, violent extremism breaks

18 A. Sardá, Las y los activistas por los derechos de las mujeres definen los fundamentalismos religiosos, "Shareen Gokal and Saira Zuberin" 2007, available at http://www.awid.org/ sites/default/files/atoms/files/las_activistas_definen_los_fundamentalismos_religiosos.pdf, accessed 8 January 2016.

19 Women's Islamic Initiative in Spirituality and Equality, Muslim Women Leaders at the Frontlines of Change, available at http://www.wisemuslimwomen.org, accessed 4 January 2016. 
individuals, families and communities, preventing people from completely reaching their potential as social and spiritual beings. It mutilates societies, causing them to fall, and creates relationships based on mistrust and intolerance at the core of the society. Violent extremism damages the name and reputation of Islam globally, spreading flagrant distortions about the Quran and the example of the prophet Muhammad.

The feminist fight of Muslim women is structured around the principles and values of women's rights and social justice ordained by the Quran. The emergent movement of Muslim women in search for gender equality acts from an Islamic perspective to bring about a change of laws and culturally discriminatory or restrictive habits, to eradicate discrimination and the patriarchal cultural practices contradictory with the Quran, such as ablation, stoning to death, forced marriages, physical punishment, political isolation and social reclusion.

One of the goals of Islamic feminist networks is to highlight the value of the gender equality principles from a religious perspective through investigation, documentation, information, divulgation and the capacity to create and build strategic interventions for empowerment, with the aim of achieving gender equality.

\section{Conclusion}

The conclusions that can be outlined from this chapter can be divided as follows. The current phenomenon of women joining Daesh has increased in numbers, but their role in it remains the same: it is still concentrated at a domestic level with less support and a secondary role compared to that of men. The belief that women only carry out supporting tasks corresponds to gender stereotypes that associate women with tenderness, compassion, sensitivity, affection, care and submission. Stereotyping as with the division of labor between men and women is based on physical differences and the different capacities to carry out certain acts and the purpose and primary task of a woman is to be a mother and wife instead of having an identity. Accepting those stereotypes, female terrorists become an anomaly, something irrational.

Another important point in the development of this research is the profile and the motivations of these women. The first is so varied that it becomes impossible to determine a standard portrait. In the same way, the motivation they find to seek and immerse themselves into the conflict is very wide and there is no possibility to draw a clear line of argument. We can only conclude that their social and psychological vulnerability and religious extremism make the recruitment easier and the combination of the two factors is an invitation to radicalization. 
Detachment from Western values and culture and from the way of practicing religion by the majority of Muslims become common causes in the minds of these women to see Daesh as an idealistic society, where they can develop their strict and, at the same time, extreme interpretation of the Islamic law.

One of the saddest conclusions that can be drawn from this work is that the use of women to commit suicide attacks is one of the most extreme forms of women's manipulation and exploitation.

As the above point makes clear, it becomes necessary to develop a system of intervention to prevent radicalism, based on the following key factors:

- A social community intervention oriented in two ways, to the Muslim communities and the societies where they are integrated, so that "difference" changes from being controversial and a source of mutual mistrust, into being an incentive to mutual social knowledge that would benefit the empowerment process of Muslim women. ${ }^{20}$

- Group empowerment from a community perspective related to women and gender inequality toward Muslim communities and the societies where they integrate.

- The utilization of Islamic feminism as a key prevention point, the European Muslim communities and the Islamic feminist movement wish to fill a place of full civic and social belonging, associated in a natural way to the values and principles of human rights and the European and international judicial heritage. The normalized coexistence among cultures and religions in the European setting is not an option - it is an inevitable destiny according to the current era of coexistence and fusion of civilizations, one of the most benevolent effects of globalization. The social reaction in favor of diversity requires a community intervention where social work, an independent scientific discipline, can provide solid support, finding the contexts where Muslim women suffer discrimination, and taking appropriated actions to end it. We need to develop an integrative and holistic perspective of human rights within gender specialization networks.

Islam's position is categorical and unequivocal to the acts carried out by these people who call themselves Muslims: it categorically condemns terrorism. The issue in question is that the acts perpetrated by Daesh are not Islamist at all. In fact, it is offensive to the people professing Islam as the religion of peace. And its acts

20 R. Torres and L. Ponce, Reislamización digital y yihadismo europeo: claves comprensivas para la intervención social comunitaria, "Sistema" no. 240, 2015, pp. 101-116. 
are condemned by the global Muslim community. There is no possible interpretation of the Quran that can lead to justifying beheadings, murder or torture to the people they call enemies. Islam defends and protects in its sacred texts freedom of creed and thought. The terrorists, however, go in the opposite direction to what Islam preaches. The proof to this categorical conclusion is that 20 billion Muslims in the EU and 40 billion in the whole European continent are characterized by being a majority which accepts the social and democratic rule of law.

The dimension of full social belonging is an underlying objective in every public intervention oriented to Daesh's eradication. The construction of a fairer global system and, inside this one, a European Union that returns to the expansive construction of social cohesion, remains an essential part of a long-term solution targeting violent radicalization. The social and cultural answer must be as firm as the one from the military and police; however, it is not yet visible, as shown by the Syrian refugee drama.

One contextual condition unavoidable in eradicating jihadist terrorism is still a pending subject: socio-political freedom and the democratization of countries with Arab Muslim majority. The geopolitics of Western countries, Russia and the countries of the region, create a dimension that has influenced a drift toward destabilization, conflict and internal wars, putting an end to the hopes of democracy born after the Tunisian Arab Spring. The result is the fragmentation of Syrian, Iraqi and Libyan territory and the return of the political support of dictatorships (like the one Egypt) which uphold the status quo.

\section{References}

M. Castells, La era de la información. Economía, Sociedad y Cultura. Volumen II: El poder de la identidad, Alianza Editorial, Madrid 1998.

C. Garcia, Las Mujeres del Estado Islámico, Instituto Elcano, 2001, avalilable at http://www.realinstitutoelcano.org/wps/portal/web/rielcano_es/contenido?WCM_GLOBAL_CONTEXT=/elcano/elcano_es/zonas_es/terrorismo+internacional/comentario-garciacalvo-las-mujeres-del-estado-islamico, accessed 5 January 2016.

C. Hoyle, A. Bradfor, R. Frenett, Becoming Mulan? Female Western Migrants to ISIS, Institute for Strategic Dialogue (ISD), 2015, available at http://www.strategicdialogue.org/publications/, accessed 4 January 2016.

A. Lamrabet, El Corán y las mujeres: Una lectura de liberación, Icaria Antrazyt, Barcelona 2011.

M. Lopez, J. Morales and A. Lisbona, Evolution of Gender Stereotypes in Spain: Traits and Roles, "The Spanish Journal of Psychology" no. 11, 2008. 
H. Padilla, La mujer en el islam, feminismo islámico, Centro de Estudios Internacionales para el Desarrollo (CEID), Buenos Aires 2011.

S. Ramachandran, Women Suicide Bombers Defy Israel, "Asia Times", available at www.atimes.com/atimes/Middle-East/EJ25Ak02.html, accessed 2 January 2016.

A. Rubin, Woman says she told police about Paris attacker's hide-out, "The New York Times" 2008, available at http://www.nytimes.com/2016/02/05/ world/europe/woman-says-she-told-police-about-paris-attackers-hide-out. html?ref=topics\&_r=0, accessed 6 January 2016.

A. Sardá, Las y los activistas por los derechos de las mujeres definen los fundamentalismos religiosos, "Shareen Gokal and Saira Zuberin" 2007, available at http:// www.awid.org/sites/default/files/atoms/files/las_activistas_definen_los_fundamentalismos_religiosos.pdf, accessed 8 January 2016.

M. Silvestre, R. Royo, E. Escudero, El empoderamiento de las mujeres como estrategia de intervención social, Universidad de Deusto, Bilbao 2014.

R. Torres and L. Ponce, Reislamización digital y yihadismo europeo:claves comprensivas para la intervención social comunitaria, "Sistema" no. 240, 2015.

The noble Quran, available at http://quran.com/, accessed 4 January 2016. 
Anna Sroka and Katarzyna Trofimowicz

\section{Terrorism and Political Radicalism in the Security Strategies of Poland and Spain versus Public Opinion}

\section{Introduction}

Since the 9/11 attack on the World Trade Center in New York, the issues of terrorism and political radicalism have assumed their place among the leading dangers of the contemporary world. While neither terrorism nor radicalism are themselves new phenomena, since the aforementioned attack they have assumed a new form, becoming associated primarily with the Islamic fundamentalism. However, it should be emphasized that the level of threat posed by terrorism and radicalism is not uniform. In respect of the extent of the danger posed by terrorist attacks and the activities of extremist groups, Poland and Spain, which will be subjected to analysis in this article, undoubtedly display significant differences.

For years, Spain has been faced with terrorism by the ETA; it has also been a victim of terrorism following the March $11^{\text {th }}, 2004$ attack carried out by Islamic fundamentalists. Additionally, proximity to northern Africa and the number of immigrants arriving from that region has a direct impact on growing political radicalism grounded in religious fundamentalism. In Poland, however, we are faced with a relatively low prevalence of terrorist attacks and radicalism. It may be expected that the differences in the concentration of terrorist threats and escalation of radicalism will be reflected in legislation addressing such issues, including security planning. Nonetheless, it should be kept in mind that the creation of security strategies is influenced not only by the scale of the terrorist threat and the escalation of political extremism, but also by a broad range of both external and internal determinants. These include membership in international organizations, alliances, legislative trends, geopolitical position, and traditional military threats associated with them (war).

The objective of the first portion of this article is to analyze the security strategies and other strategic documents of Poland and Spain in respect of the weight given in each of them to the issues of terrorism and political radicalism. This will facilitate an assessment of the impact of those threats on the state security strategies as a whole. Next, an analysis will be undertaken of selected international factors conditioning the shape of security strategies in the analyzed countries. 
Later on, we shall provide a presentation of the correlation between public opinion polling results and changes in legal regulations concerning terrorism and radicalism in Poland and Spain.

Structuring the investigations in this manner allows for an answer to the following questions: to what extent do the threats associated with terrorism and political radicalism constitute a factor shaping a given state's security strategy? To what degree do external determinants contribute to changes in security strategies in the two countries? If they do, to what extent are changes in strategic documents regarding national security a response to the increased perceptions among Poles and Spaniards of the threat of terrorism and radicalism? The first of the hypotheses to be tested is the following: with consideration given to the greater threat of terrorism and political radicalism in Spain when compared to Poland, each of these phenomena will exert a greater impact on the shape of security strategy in Spain than in Poland. Having regard to the similar geopolitical situation of the two countries, it is assumed that the influence of external factors on the content of strategic documents dealing with terrorism and radicalism will be comparable in Poland and in Spain. In Spain, changes in legal regulations regarding terrorism and radicalism are linked to a greater extent than in Poland with public opinion polling, which is itself the result of a far more immediate perception of the threat of terrorism. The date of September $11^{\text {th }}, 2001$, marking the beginning of the socalled "war on terror", is regarded as a milestone date.

\section{The Issue of Terrorism and Radicalism in Strategic Documents in Poland and Spain}

Given the space limitations for this article, we shall not engage in an analysis of the body of legislation addressing the struggle with terrorism and radicalism. Instead, we will focus on national defense strategies and other strategic documents that are a sort of emanation of the attitude taken by public authorities toward such threats. Furthermore, it is worth adding that neither in Poland nor in Spain is there one overarching piece of legislation regulating the issue, and laws regulating anti-terrorist efforts are primarily contained in Penal Codes and other statutes regulating the activities of particular services.

In Poland, during the period 2001-2015, three national security strategies were in effect: the first was adopted in 2003, the second in 2007, and the third in 2014. Here, it is worthy to recall the first such strategy, adopted in 2000, before the attack on the World Trade Center. It was the result of Poland's accession to the NATO in 1999. During the same period, a strategic conception for the Alliance was developed. However, Poland did not make use of its potential to affect 
the NATO strategy, and its internal document was adopted around a year after it joined the organization, based on its conception. This was also a mistake if we take into consideration that, during a year of membership in NATO, Poland followed a strategy developed in conditions of strategic independence. In Stanisław Koziej's opinion, this was the result of habits formed during the years of membership in the Warsaw Pact, when this strategic alliance was superior to national strategies. ${ }^{1}$

When examining more closely Polish security strategies, it may be observed that the issue of terrorism is present, but it is not perceived as one of the primary threats. It is generally listed along with other asymmetrical threats such as organized crime, arms proliferation or "failing states." There is a fear about the security of secret information which can be the target of interest of not only foreign intelligence services but also terrorist and extremist organizations. ${ }^{2}$ Emphasis is placed on the necessity of cooperation in the fight against terrorism between the armed forces and special services, on the one hand, and civilian authorities, on the other. ${ }^{3}$ What is also underscored is the responsibility resting with the armed forces and intelligence services in the context of anti-terrorist activities. ${ }^{4}$ Because of Poland's membership in NATO, the country is a participant in the struggle against international terrorism, which does expose it to the threat of attacks. ${ }^{5}$ The threat of terrorism associated with organized crime is also present in Poland considering its status as a transitive country. ${ }^{6}$ Counterterrorism is also a part of the European Union's strategy. ${ }^{7}$ The issue of protecting the health of citizens

1 S. Koziej, A. Brzozowski, 25 lat polskiej strategii bezpieczeństwa, „Bezpieczeństwo Narodowe" II no. 30, 2014, pp. 13-14.

2 Strategia bezpieczeństwa narodowego Rzeczypospolitej Polskiej 2003, Rada Ministrów Rzeczypospolitej Polskiej, accessed 8 February 2016, pp. 2-3.

3 Ibid. p. 5.

4 Ibid. pp. 9-11; Strategia bezpieczeństwa narodowego Rzeczypospolitej Polskiej 2007, Rada Ministrów Rzeczypospolitej Polskiej, point 95, 97, 99, 102, pp. 23-25 available at http://www.msz.gov.pl/resource/7d18e04d-8f23-4128-84b94f426346a112, accessed

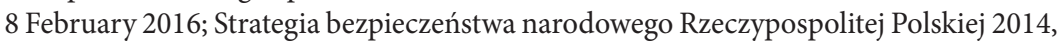
Rada Ministrów Rzeczypospolitej Polskiej, point 74, pp. 31 available at https://www. bbn.gov.pl/ftp/SBN\%20RP.pdf, accessed 8 February 2016.

5 Strategia bezpieczeństwa narodowego Rzeczypospolitej Polskiej 2003...op.cit., p. 6; Strategia bezpieczeństwa narodowego Rzeczypospolitej Polskiej 2007...op.cit., point 34, p. 9; Strategia bezpieczeństwa narodowego Rzeczypospolitej Polskiej 2014...op.cit., point 55, p. 25.

6 Strategia bezpieczeństwa narodowego Rzeczypospolitej Polskiej 2014...op.cit., point 36, p. 9.

7 Ibid. point 47: 13). 
through combating radioactive, chemical and biological terrorism has also been addressed. ${ }^{8}$ References to terrorist threats in the strategies of 2003 and 2007 are diffuse, generally located alongside other threats or in reference to the tasks of various security services. Terrorism, as a subject in and of itself, has not been focused on, being perceived as a distant threat.

In the 2014 strategy, the issue of terrorism appears in combination with extremism, radical groups and radicalization of behaviors, all of which should be counteracted. ${ }^{9}$ Extremism is assessed as a threat, particularly in situations when it is associated with other asymmetrical threats such as the proliferation of weapons of mass destruction ${ }^{10}$ and organized crime. ${ }^{11}$ The issue of cyberthreats is also brought up, including cyberterrorism. ${ }^{12}$ It should be observed that in the 2014 strategy, more space was devoted to terrorism and extremism than in previous documents. They remain classified not as primary threats, but rather as one of many potential threats. However, attention is clearly paid to the issue, and it is not taken lightly. This is no doubt associated with the growth of the so-called Islamic State, frequent terrorist attacks around the world and the fact that, while Poland has yet to experience such an attack, Polish citizens did perish in attacks in Madrid, London, New York and Bali. ${ }^{13}$ However, consideration is given to the potential for both domestic and international terrorist acts by the so-called "lone wolves" or small groups. ${ }^{14}$

We may observe a similar approach to the issue of terrorism in the Strategy for Development of the Polish National Security System 2022, adopted by a resolution of the Council of Ministers on April $9^{\text {th }}$, 2013. In this document, terrorism is presented as one of several threats, including the proliferation of weapons of

8 Ibid. point 136: 34).

9 Strategia bezpieczeństwa narodowego Rzeczypospolitej Polskiej 2014...op.cit., point 19, 32, 83, pp. 14, 19, 24.

10 Ibid. point 28, p. 18.

11 Ibid. point 30, pp. 18-19.

12 Ibid. point 31, pp. 19.

13 J. Urbanowicz, 17 Polaków zginęło z rąk terrorystów islamskich podczas globalnej wojny z terroryzmem, Polskie Radio 2015, available at http://www.polskieradio.pl/5/3/ Artykul/1402579,17-Polakow-zginelo-z-rak-terrorystow-islamskich-podczas-globalnej-wojny-z-terroryzmem, accessed at January 2016; Narodowy Program Antyterrorystyczny na lata 2015-2019, Uchwała nr 252, Rada Ministrów Rzeczypospolitej Polskiej 2014, p. 10, available at www.monitorpolski.gov.pl/mp/2014/1218/M2014000121801. pdf, accessed 8 February 2016.

14 Strategia bezpieczeństwa narodowego Rzeczypospolitej Polskiej 2014...op.cit., point 55, p. 25. 
mass destruction, organized crime and cyberattacks. It is also mentioned in the context of armed conflicts around the world, and the problem of "failed states." It is described as a threat that does not affect the territory of Poland as much as the country's citizens staying in politically unstable regions, and soldiers participating in international missions. However, responsibilities under alliances do increase the level of the threat within the country as well. Counteracting terrorism is held to be one of the tasks for the special services, and the authors of the strategy direct particular attention to the issue of weapons of mass destruction in the hands of terrorists. ${ }^{15}$ In this strategy, the emphasis has been placed on the military aspect of national security; this is associated with the fact that it comprises one of the documents making up Poland's long-term strategy of linking security policy with policy in the sphere of social and economic development. Other documents address issues of energy, social and ecological security, together forming a comprehensive picture of national security. The Strategy for Development of the Polish National Security System 2022 is the implementation of the postulates from the 2007 security strategy, whose assumptions included the necessity of preparing, maintaining and improving the state's security system, as well as long-and medium-term development strategies. ${ }^{16}$

Another document worthy of mention is the 2013 White Paper on National Security of the Republic of Poland. This document draws attention to the diffusion of anti-terrorist legislation, as well as of means for counteracting terrorism. ${ }^{17}$ This is significant, as the White Paper was prepared on the basis of the Strategic Review of National Security, and contains the key conclusions and recommendations regarding Poland's national security policy, including improvements in the security system. ${ }^{18}$ In spite of the continuing minimal terrorist threat in Poland, the country's authorities are aware of the problem; this awareness is expressed in the National Anti-terrorism Program for 2015-2019, adopted by the Council of Ministers in December 2014. It contains a broader diagnosis of the phenomenon of terrorism than

15 Strategia rozwoju systemu bezpieczeństwa narodowego Rzeczypospolitej Polskiej 2022, Rada Ministrów Rzeczypospolitej Polskiej, 2013, pp. 3, 10-12, 23, 33, 49 available at https://www.bbn.gov.pl/ftp/dok/01/strategia_rozwoju_systemu_bezpieczenstwa_narodowego_rp_2022.pdf, accessed 8 February 2016.

16 Ibid. p. 4.

17 Ibid. pp. 64-65.

18 Biała Księga Bezpieczeństwa Narodowego Rzeczypospolitej Polskiej 2013, Biuro Bezpieczeństwa Narodowego, Warszawa 2013, p. 9, available at http://www.ank.gov.pl/komunikaty/2013/07/03/biala-ksiega-bezpieczenstwa-narodowego-rp, accessed 1 February 2016. 
in the previously discussed documents, taking into account both the national and international dimensions, as well as offering a broad review of the anti-terrorism system functioning within Poland, a definition of terrorism-related events, a list of legal regulations addressing terrorism, and a description of the anti-terrorist system in place. We can also browse a presentation of Poland's contribution to international cooperation in the fight against terrorism. ${ }^{19}$ The National Anti-terrorism Program is the executive document in relation to the Strategy for Development of the Polish National Security System. The last document that should be mentioned is the Polish Cybersecurity Doctrine, from 2015. This document includes an identification of terrorist and extremist organizations as sources of cyberthreats, and cyberspace is defined as a field where such organizations can be active. ${ }^{20}$ The starting point for this doctrine can be found in the determinations of the national security strategy for cyberspace, as well as the Policy for the Protection of Poland's Cyberspace and the EU Cyber Security Strategy. ${ }^{21}$

The Spanish authorities have adopted two national security strategies to date, in 2011 and 2013. Previously, strategic issues were regulated primarily in National Security Directives issued every 4 years, beginning in $1992 .{ }^{22}$ One of the subjects discussed, as can be supposed, was terrorism. Already in 2003, the Strategic Security Review observed that following the attack on the World Trade Center, terrorism had emerged as the most prominent threat to national security, and the fight against it was a key issue in the strategy for organizing international security. ${ }^{23}$ In the 2004 National Defense Directive, the first issued during the period under review, emphasis is placed on the asymmetrical dimension of terrorism, and on the fact that when faced with threats of this nature, a traditional military advantage does not play any significant role $;^{24}$ however, in the next Directive from

19 Narodowy Program Antyterrorystyczny...op.cit., pp. 8-34.

20 Doktryna Cyberbezpieczeństwa Rzeczypospolitej Polskiej, Biuro Bezpieczeństwa Narodowego, Warszawa 2015, pp. 5, 14, available at https://www.bbn.gov.pl/ftp/dok/01/ DCB.pdf, accessed 1 February 2016.

21 Ibid. p. 7.

22 Instituto Español de Estudios Estratégicos, La Directiva de Defensa Nacional 2012, p. 2, available at http://www.ieee.es/Galerias/fichero/docs_analisis/2012/DIEEEA35-2012_ DDN_IEEE.pdf, accessed 1 February 2016.

23 Revisión Estratégica de la Defensa 2003, Ministerio de Defensa, pp. 39, available http://www.defensa.gob.es/Galerias/defensadocs/revision-estrategica.pdf, accessed 8 February 2016.

24 Directiva de Defensa Nacional 2004, Gobierno de España, pp. 1-2, available at http:// www.centredelas.org/images/stories/adjunts/510_ddn_2004.pdf, accessed 4 February 2016. 
2008 there is no mention of terrorism or radicalism. ${ }^{25}$ In turn, the 2012 Directive was criticized for failure to address the real threat of terrorism associated with jihad. Under this directive, Spain's national security should be primarily based on alliances and membership in international organizations, while the primary threat cited is the economic crisis. ${ }^{26}$

The first Spanish security strategy, "Shared Responsibility," was confirmed on June $24^{\text {th }}, 2011 .{ }^{27}$ The second Spanish strategy currently in force, "Joint Project," was drafted in May 2013. These strategies are characterized by continuity in their content and identification of threats. In the new one, the definition of national security has been rendered more precise - for the first time it appears in an official Spanish document. ${ }^{28}$

Proceeding to the content of the national security strategy, it should be pointed out that a significant amount of space has been devoted to the issue of terrorism. First and foremost, it is listed among the most important threats in both strategies. Alongside reference to terrorism in conjunction with such threats as organized crime, cyberattacks, piracy and arms proliferation, this issue is given consideration in separate sub-chapters. ${ }^{29}$

It should be pointed out that this issue was given significant attention in the 2011 strategy, and apart from the general identification of the problem, both institutional solutions and a strategy for action in the fight with the terrorist threat

25 Directiva de Defensa Nacional 2008, Gobierno de España, available at http://www. armada.mde.es/ArmadaPortal/ShowBinaryServlet?nodePath=/BEA\%20 $\overline{\text { Repository/ }}$ Desktops/Portal/ArmadaEspannola/Pages/documentacion_reglamentos/07_directiva_defensa_nacional/01_directiva_defensa_nacional_es/doc_01_directiva_defensa_nacional08//archivo, accessed 12 February 2016.

26 D. López Garrido, "El País" 10.08.2012, available at http://elpais.com/elpais/2012/08/07/ opinion/1344351717_982529.html, accessed 8 February 2016; Directiva de Defensa Nacional 2012, Presidencia del Gobierno, available at http://www.defensa.gob.es/Galerias/defensadocs/directiva-defensa-nacional-2012.p $\overline{\mathrm{df}}$, accessed 8 February 2016.

27 L. Mestres, The long road to Spanish security strategy, Notes Internacionals CIDOB, no. 39, 2011, p. 1.

28 Estrategia de Seguridad Nacional 2013: Un proyecto compartido, Presidencia del Gobierno, available at http://www.lamoncloa.gob.es/documents/seguridad_1406connav egacionfinalaccesiblebpdf.pdf, accessed 8 February 2016, p. 5-6.

29 Ibid. pp. 25-26; Estrategia Española de Seguridad 2011: Una responsabilidad de todos, Gobierno de España, pp. 49-52, available at http://www.realinstitutoelcano.org/wps/ wcm/connect/c06cac0047612e998806cb6dc6329423/EstrategiaEspanol DeSeguridad. pdf?MOD=AJPERES\&CACHEID=c06cac0047612e998806cb6dc6329423, accessed 8 February 2016. 
are presented. Two types of terrorism are distinguished: the threat from ETA, and the threat from jihadist movements (Al Qaeda, Islamic State). This threat is enhanced by such factors as participation in international missions, the presence of Islamic fundamentalist groups in Spain promoting radical ideas, including the reconstruction of the Islamic $\mathrm{Al}$ Andalus, ${ }^{30}$ proximity to the unsettled region of Maghreb, the existence of "failed states," and the potential for immigrants coming to Spain to adopt radical ideologies, including second-generation immigrants. The war on terrorism is to be conducted through the following means: simplifying the exchange of information among security services, invocation of the EU solidarity clause (Art. 22 of the Treaty on the Functioning of the European Union), the functioning of the National Centre for Coordination of Anti-terrorist Activities (since 2014 the Intelligence Centre for the War on Terrorism and Organized Crime), enhancements to the domestic judicial system and international judicial cooperation in terrorism-related cases, participation of the armed forces and all of public administration, increased financing and human resources, strengthening the National Intelligence Centre, development of a planned response to nuclear, radiological, biological and chemical attacks, improved transport security and greater effectiveness of external border controls, special penitentiary policy in cases of terrorism, and participation in international missions. However, it is emphasized that in spite of potential future attacks, terrorists do not have the capacity to destabilize the rule of law or democracy as such. ${ }^{31}$ Attention is also drawn to the fact that radical and extremist ideologies can intensify threats to national security. ${ }^{32}$

In the 2013 strategy, less attention is devoted to the issue of terrorism, with only a diagnosis of the threat offered. The Spanish government's priority is to prevent terrorists from being able to conduct their activities. It is emphasized that the

30 Recordings from ISIS have appeared in recent days in which terrorists have discussed punishing Spaniards for driving muslims out of Spain, and have expressed the desire to rebuild the Islamic Al Andalus, F. Carrión, El IS advierte a Espana que "pagara muy caro" la expulsion de los musulmanes de Al Andalus, "El Mundo" 31.01. 2016, available at http://www.elmundo.es/internacional/2016/01/31/56adefc1268e3e5d0d8b4580.html, accessed 1 February 2016.

31 Estrategia Española de Seguridad 2011...op.cit., pp. 49-52.

32 Ibid. pp. 38-39; R. Alonso Pascual, Ideologías radicales y no democráticas como potenciadores de riesgo para la seguridad nacional, "Cuaderno de Estrategia", Instituto Español de Estudios Estratégicos, no. 159, 2013, pp. 229-268, available at http://www. ieee.es/Galerias/fichero/cuadernos/CE_159_Potenciadores_de_Riesgo.pdf, accessed 1 February 2016. 
coordination of responses across all of the state services and society has led to the neutralization of ETA. The prime terrorist threat is perceived in the activities of jihadist groups, which take advantage of extensive technological capacities and the globalized nature of the contemporary world. Potential justifications for Spain as a terrorist target are listed, such as proximity to the failed states of the Sahel, and Spain's role in the struggle against international terrorism. Spain's experiences in this battle are referred to. A greater portion of the document is devoted to issues of energy, economic and cyber security. ${ }^{33}$

This last threat was the subject of separate documents, i.e. the National Cyber Security Strategy of 2013 and the National Energy Security Strategy of 2015. ${ }^{34}$ These documents constitute an elaboration of the national security strategy in the spheres of energy and cyber security. In recent years, these areas have become increasingly important, and will continue to do so. They have developed into very important elements of the national security picture, with cyber security evolving into a particularly serious challenge considering the difficulty in predicting the targets and impacts of cyberattacks, as well as the constant development of information technology.

Lastly, we may recall the National Maritime Security Strategy of 2013, important in view of Spain's geographical location. Terrorism can also be a threat to the country's stable maritime policy, as can piracy, illegal immigration by sea, illegal use of maritime resources, or the proliferation of weapons of mass destruction. The hijacking of passenger ships or attacks on transport and navy vessels may be used later on to engage in attacks on land. ${ }^{35}$

33 Estrategia de Seguridad Nacional 2013: Un proyecto, op.cit., pp. 25-26.

34 Estrategia de Ciberseguridad Nacional 2013, Presidencia del Gobierno, available at http://www.lamoncloa.gob.es/documents/20131332estrategiadeciberseguridadx.pdf, accessed 8 February 2016; Estrategia de Seguridad Energética Nacional 2015, Presidencia del Gobierno, available at http://www.lamoncloa.gob.es/serviciosdeprensa/notasprensa/Documents/ESTRATEGIA\%20DE\%20SEGURIDAD\%20ENERGÉTICA\%20 NACIONAL\%20(WEB).pdf, accessed 1 February 2016.

35 Estrategia de Seguridad Marítima Nacional 2013, Presidencia del Gobierno, pp. 4, 12, 19, 24, available at http://www.iee.es/Galerias/fichero/OtrasPublicaciones/Nacional/ Estrategia_Seguridad_Maritima_Nacional_2013.pdf, accessed 8 February 2016. 


\section{Impact of the International Environment on the Contours of Security Strategies in Poland and Spain}

The first of the Polish strategies in the analyzed period was developed in 2003, and was associated with the emergence of new challenges and threats in the international sphere, as well as with a transformation of the security environment. The first factor was undoubtedly the 11 September 2001 attack on the World Trade Center. Alliance with the USA and support for that country's battle with terrorism meant that from that time on, Poland also had to contend with the possibility of becoming a target for terrorist activities. Not without importance was Poland's participation in war in Afghanistan and Iraq. Membership in NATO required that Poland's strategy be adapted to the conditions of participation in a military alliance, consideration for shared interests and challenges. NATO itself underwent a transformation, expanding and shoring up its cooperation with Russia and Ukraine. Poland's imminent accession to the European Union constituted another new context for the country's security policy. The document's authors therefore felt that the dynamics of the changes required Poland to revise its security strategy and policy. ${ }^{36}$ National security was captured in a holistic manner, as a category encompassing all aspects of state security: external and internal, military and civilian. However, it offered no definition of national interests, which are precisely what should constitute the starting point for determining strategic objectives and the entire national security strategy. This strategy was consistent with many new trends in the spheres of domestic and international security, focused on the most prominent issues at the moment. Having said that, one should also be aware that it had numerous weaknesses, including that of excessive brevity, which is why work on its revision was quickly undertaken. ${ }^{37}$

Several reasons can be cited for the creation of the next strategy, adopted in 2007. Apart from the aforementioned weakness of the 2003 strategy and necessity of updating it, Poland's national security situation was subjected to a significant change with the country's accession to the European Union in 2004. Poland's new security strategy was adapted to be compatible with the 2003 European Security Strategy, as well as with the assumptions adopted during the 2006 NATO summit in Riga. This strategy made up for the substantive shortfalls in the previous ones, including national interests and strategic objectives, alongside analysis of the conditions of security and the opportunities and threats facing it. A holistic

36 Strategia rozwoju systemu bezpieczeństwa narodowego Rzeczypospolitej Polskiej 2022 ...op.cit., p. 1.

37 S. Koziej, A. Brzozowski, 25 lat...op.cit.; pp. 22-27. 
approach to security was employed, which led to significant amounts of space in the document being devoted to its various sectors, such as energy and society. ${ }^{38}$

The strategy presently in force was adopted in 2014 , and experts are generally in agreement that this was later than the dynamic changes occurring in the international arena would have dictated. The first such symptom was the eruption of the Russia-Georgia war in 2008. Another factor was the change in the USA's policy toward Russia and withdrawal from the missile shield project in Poland. Work on a new strategy was, however, hindered by the intensifying political conflict taking place in the country, and by the tragic crash of the presidential plane in Smolensk. In December 2010, the order was given to conduct a Strategic Review of National Security, completed in September 2012; the year 2013 saw the publishing of the White Paper on National Security. The results of the strategic review spurred the work on the new strategy. During that period, conflict in Ukraine also broke out. ${ }^{39}$ The increased significance of cybersecurity was influential on the development of the new national security strategy, as were fears about the security of the country's energy supply. Additionally, work was undertaken within the EU and NATO concerning security and a strategic conception. In 2010, the European Union Internal Security Strategy was adopted. That same year, the summit in Lisbon saw the introduction of a new NATO Strategic Conception, which was later updated at the September 2014 summit in Newport, following the outbreak of hostilities in Ukraine. At the time, it was decided that NATO's eastern flank would be strengthened through joint exercises, the establishment of logistics bases, and of forces capable of rapidly reaching a threatened territory. ${ }^{40}$

The Strategy for Development of the Polish National Security System 2022 arose as the implementation of the provisions contained in the 2007 national security strategy, which assumed a more systematic organization of the state's security system, as well as the elaboration of postulates for the country's medium and long-term development. It was also adopted in conjunction with the necessity of consolidating the national security system in the face of the challenges listed in

38 Ibid. pp. 28-32; Strategia bezpieczeństwa narodowego Rzeczypospolitej Polskiej 2007 ... op.cit., p. 7.

39 A. Jagnieża, Nowa Strategia Bezpieczeństwa Narodowego w obliczu kremlowskiego egzaminatora, Defence24 2014, available at http://www.defence24.pl/148404,nowa-strategia-bezpieczenstwa-narodowego-w-obliczu-kremlowskiego-egzaminatora, accessed 8 January 2016.

40 T. Smura, Szczyt NATO w Newport - powrót do podstaw, Fundacja Pułaskiego, Defence24 2014, available at http://www.defence24.pl/122717,szczyt-nato-w-newport-powrot-do-podstaw, accessed 18 February 2016. 
the document, primarily doubts as to the effectiveness of the international security architecture, differences among NATO members, and weakening interest on the part of the USA in European matters. The adoption of a strategy through 2022 results from the need to harmonize its time horizon with executive documents concerning defense planning, themselves determined by the NATO planning cycle. ${ }^{41}$ This strategy also determined the creation of the National Anti-terrorist Program for 2015-2019. The existence of such a program results from efforts at consolidating the functioning of Poland's anti-terrorist system, which - as has been previously mentioned - is quite diffuse. The need to place considerable emphasis on the issue of terrorism is the result of the Islamic State's increased activities, as well as the high frequency of attacks around the world. In turn, the development of a Cybersafety Doctrine is linked to the rapid development of technology, accompanied by highly unpredictable cybercrime, which is becoming increasingly dangerous as a result of the ever-expanding presence of information technology in every aspect of life.

In respect of the creation of a Polish national security strategy, we may cite the impact of membership in the NATO and the EU among the external factors affecting the shape of these documents. Their authors also place strong emphasis on the involvement of the USA in Europe. The period in which these strategies were drawn up cannot be associated directly with a particular terrorist attack, perhaps apart from 9/11; nevertheless, that event itself was not the sole factor influencing the adoption of the strategy in 2003; rather, it has stimulated the general change in the international situation after the attack. The impact of the international situation is clearly visible in documents focused on individual aspects of national security. These include a response to the growing threat of terrorism (if not within the borders of Poland itself, at least toward its citizens) or of cyberattacks.

In Spain, the army exercised strong influence over politics and played a significant role in society, beginning in the $19^{\text {th }}$ century. This continued through the next century, as the military dictatorship established during the Civil War by Gen. Franco was preceded by the governments of Gen. Primo de Rivera (1923-1930). At present, the armed forces are among the institutions in Spanish society that enjoy the highest level of trust..$^{42}$ This is also why a traditional approach to issues

41 P. Kmiecik, Nowastrategia.org.pl, Analiza krytyczna strategii rozwoju systemu bezpieczeństwa narodowego RP do $2022 \mathrm{roku}, 2015$, available at http://www.nowastrategia. org.pl/analiza-krytyczna-srsbn/, accessed 8 February 2016.

42 Centro de Investigaciones Sociológicas (CIS), Barómetro de Abril 2015, Estudio no. 3080, pp. 9-10, available at http://www.cis.es/cis/export/sites/default/-Archivos/Marginales/3080_3099/3080/es3080mar.pdf), accessed 8 February 2016. 
of security was employed, with the issue perceived primarily in military terms. It was not until the White Paper on Defense in 2000 that issues associated with new challenges in security were captured. Attention was drawn to the globalization processes shaping the modern world, as well as the threats and opportunities for state security that resulted and the concomitant necessity to engage in global-scale strategic thinking. ${ }^{43} \mathrm{~A}$ reversal in thinking about asymmetrical threats, including terrorism, was brought about by the $9 / 11$ attack. It was one of the factors that contributed to the 2003 Strategic Security Review, in which terrorism was recognized as a key threat to countries belonging to international defense-oriented alliances. ${ }^{44}$

The drafting of Spain's' first security strategy was a response to the previous lack of a comprehensive strategic conception and the exclusive focus on the military aspects of security. Statements appearing in the documents to the effect that the Spanish strategy was developed under the influence of similar documents in effect in neighboring countries, such as France, the United Kingdom, and the Netherlands, as well as the 2003 EU security strategy, indicate a particular trend in legislation as one of the roots of the strategy's adoption. ${ }^{45}$ Another factor is the new NATO Strategic Conception that emerged during the Lisbon summit. ${ }^{46}$

The strategy's update in 2013 was most certainly influenced by changes in the international situation, such as the Arab Spring, and changes in the USA's strategic assumptions. ${ }^{47}$ In spite of the significant place occupied in Spain's security strategies

43 Libro Blanco de Defensa 2000, Ministerio de Defensa, pp. 29-30, available at http:// www.defesa.gov.br/projetosweb/livrobranco/arquivos/pdf/Espanha\%202000.pdff, accessed 15 February 2016.

44 M.A. Franco García, De las Directivas de Defensa Nacional a la Estrategia de Seguridad Nacional: tendencia a la integración de capacidades cívico-militares en el ámbito marítimo, "Revista del Instituto Español de Estudios Estratégicos" no. 3, 2014, pp. 5-6.

45 L. Mestres, The long road...op.cit., p. 1; Instituto Español de Estudios Estratégicos (IEEE), 2010, El contexto de elaboración de la Estrategia Española de Seguridad, available at http://www.ieee.es/Galerias/fichero/2010/DA-IEEE_02-2010_EL_CONTEXTO_DE_ELABORACION_DE_LA_ESTRATEGIA_ESPANOLA_DE_SEGURIDAD. pdf, accessed 1 February 2016.

46 Instituto Español de Estudios Estratégicos, 2011, Análisis comparativo de la Estrategia Española de Seguridad «Una responsabilidad de todos», p. 3, available at http://www. ieee.es/Galerias/fichero/docs_analisis/2011/DIEEEA17_2011EstrategiaEspanolaSeguridad.pdf, accessed 1 February 2016.

47 M. Laborie Iglesias, La Estrategia de Seguridad Nacional (Mayo 2013). Documento Análisis de Instituto Español de Estudios Estratégicos, no. 34/2013 2014, p. 2, available at http://www.ieee.es/Galerias/fichero/docs_analisis/2013/DIEEEA34-2013_EstrategiaSeguridadNacional-2013_MLI.pdf, accessed 8 February 2016. 
by the issue of the terrorist threat, it was not specific attacks, that influenced the updating of documents. The national security strategy was adopted 7 years after the attack in Madrid. It has led to practical changes, such as in the structure of state institutions - attention was drawn to the necessity of their coordination. On the doctrinal plane, the largest influence was had by the attack of $9 / 11$, as it demanded a reflection on the new nature of terrorism.

National defense directives are adopted in accordance with the regular, fouryear cycles of defense planning in effect. Events around the world and at home therefore impact the content of the directives, but not the frequency with which they are adopted. Defense planning and strategies are developed as forecasts for the future, but are prepared in response to events taking place around the globe and the evolving geopolitical panorama ${ }^{48}$. In the 2004 Directive, the following factors are listed as influential in the formation of such documents: changes in the international strategic situation, the presence of Spain in the international arena, the development of society, and successive governments. ${ }^{49}$ In the case of the 2008 Directive, the factors impacting its contours included terrorist attacks in Madrid, London and Beslan, on the one hand, and the passage of the National Defense Act, on the other. ${ }^{50}$ These directives reflect the parallel development of European security and defense policy, and also invoke references to membership in such organizations as the NATO, the EU and the UN as guarantors of security. In conjunction with the intensification of migration to Spain, the 2008 Directive devotes greater attention to sub-Saharan Africa. The 2012 Directive emphasizes the importance of the alliance with the United States. ${ }^{51}$

Analogically to the situation observed in Poland, three directives have been adopted in Spain, which focused on the issue of sectoral security: cyberspace, energy and national maritime security. In the case of cyberthreats, the motivation is similar to that in Poland - we are facing a highly-developed technology which entails not only a great deal of benefits but also threats. One of the ways in which the Internet is used by terrorists is in the recruitment of new supports, which must be viewed as a potential threat when considering the existence of jihadist cells in Spain. The use of cyberspace for criminal activity is also inexpensive, and it does not present barriers, such as the necessity of traveling. ${ }^{52}$ The energy security strategy emphasizes the importance of energy resources in the modern world, as

48 La Directiva de Defensa Nacional 2012...op.cit., p. 2;

49 Directiva de Defensa Nacional 2004...op.cit, p. 1.

50 La Directiva de Defensa Nacional 2012..., p. 4.

51 Ibid. pp. 6-8.

52 Estrategia de Ciberseguridad Nacional... 
well as the necessity to diversify sources in order to ensure security stable economic growth and social development. Spain is a consumer of energy resources and is dependent on their import. Stability of supply is therefore paramount, and such stability can be impacted by unforeseen events in exporting states. One of the factors influencing the contours of the strategy under discussion is the Arab Spring. ${ }^{53}$ A mention should also be made about the maritime security strategy, which is a priority owing to Spain's geographic situation. Many factors come into play here: guaranteeing supplies of energy resources, general trade, piracy, and ecological disasters along the Spanish coast. ${ }^{54}$ All three documents taken together constitute the development and implementation of the national security strategy.

In summary, much like in the case of Poland, far-reaching impact on the design of Spain's security strategy can be found in the fact of its membership in international organizations, as well as the activities of those bodies. The attitude of the United States toward the international situation plays a significant role. Because of its geographical location, events in the Mediterranean basin, such as the Arab Spring, do not go unnoticed in Spain, whose ties with the other countries in the region are strong and proximity does not allow for indifference. Spain is also one of the countries hit hardest by illegal immigration, and has been for years. Another factor that can be named is trends in the legislation of neighboring countries, as well as evolving strategic conceptions of organizations in which Spain is a member.

\section{Security Strategies and Public Opinion in Poland and Spain}

Is the adoption of a security strategy and other documents related to the issue of terrorism and radicalism correlated to some degree with public opinion? Do the previously discussed changes in strategic documents comprising the security model in place in Poland and Spain constitute a response to increased perceptions of the threat posed by terrorism and radicalism in those societies? Analysis of the results of Eurobarometer polling from the period 2005-2015 does not allow us to say definitively. It is clear that in the period 2005-2009, Spanish respondents more keenly felt the threat of terrorism than did citizens of Poland. In 2005, as many as $46 \%$ of respondents indicated terrorism as one of the two most important problems facing Spain, while only $3 \%$ of Polish respondents held the same opinion, and the European average was $10 \%$. The situation was similar in 2006, except for the difference that $10 \%$ fewer Spanish respondents than in the preceding year indicated terrorism as

53 Estrategia de Seguridad Energética Nacional...

54 Estrategia de Seguridad Marítima... 
one of the main issues to be dealt with, while these percentages in Poland and Europe as a whole remained essentially unchanged. In 2007, as many as 47\% Spanish respondents declared that terrorism was one of the country's two most pressing issues, while in Poland only 1\% did so, with the EU average being 12\%. In 2008 as well the number of Spanish respondents pointing to the issue of terrorism was high, reaching $31 \%$, while in Poland it grew by just $1 \%$, and the European average dropped to $7 \%$. Beginning in 2009, the number of Spanish respondents declaring terrorism to be one of the country's two most important issues fell dramatically: in 2009 it was 5\%, in 2010 and $201-10 \%$, in 2013 and $2014-1 \%$, and in $2015-5 \%$. In Poland, except for 2010 and 2011, the numbers were quite similar to those in Spain: in 2009, 2010, 2011, $2012-1 \%, 2013,2014-2 \%, 2015-5 \%$. In 2012 and 2015, these values were identical in Poland and Spain, while in 2013 and 2014 even more respondents in Poland felt that terrorism was one of the two most important issues.

Graph 1: The two most important problems facing each country at the current time

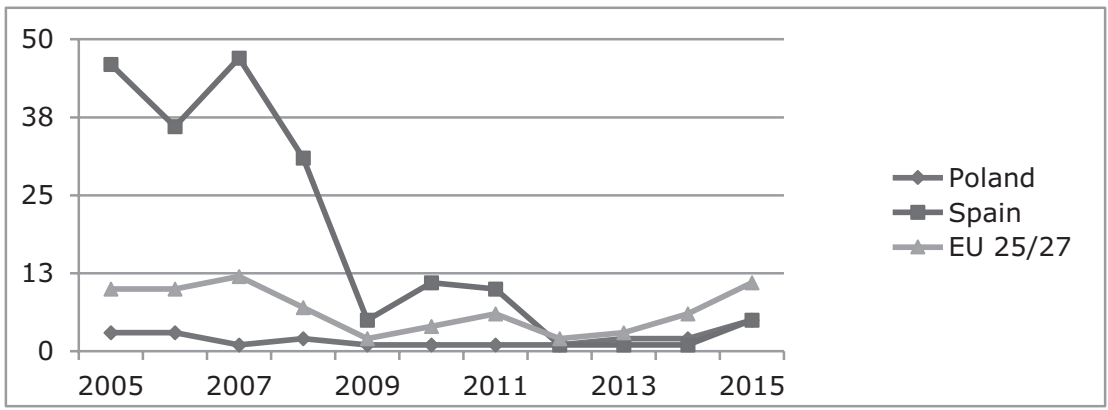

Source: Author's analysis on the basis of Eurobarometer 63, May 2005; Standard Eurobarometer, 65 March 2006; Standard Eurobarometer 67, April 2007; Standard Eurobarometer 69, March 2008; Standard Eurobarometer 71, June 2009; Standard Eurobarometer 73, May 2010; Standard Eurobarometer 75, May 2011; Standard Eurobarometer 77, May 2012; Standard Eurobarometer 79, May 2013; Standard Eurobarometer 82, November 2014; Standard Eurobarometer 84, November 2015, available at http://ec.europa.eu/COMMFrontOffice/PublicOpinion/index.cfm/Survey/ index\#p=1\&instruments=STANDARD, accessed 1 February 2016.

Analyzing the Eurobarometer results for Poland, we may observe a slight growth in the number of respondents pointing to terrorism as one of the two main problems facing the country. However, it should be emphasized that in the period 2005-2015 this number oscillated between $1 \%$ and $5 \%$, which puts respondents from Poland below the EU average (2\%-12\%). When we examine the results of Eurobarometer performed in Spain, it is not difficult to see that with the explosion of the economic crisis in 2009, Spaniards primarily indicated the economic situation (2009-40\%, 
$2010-51 \%, 2011-50 \%, 2012-61 \%, 2013-50 \%, 2014-36 \%, 2015-29 \%)$ and unemployment (2009 - 32\%, $2010-72 \%, 2011-76 \%, 2012-76 \%, 2013-79 \%$, $2014-78 \%, 2015-69 \%)$ as the two primary issues facing Spain. Thus, for citizens of Spain, the largest challenges to their country were economic issues rather than terrorism. This does not necessarily mean that issues surrounding terrorism ceased to be of importance, but only that they were not among the two most pressing issues faced by Spain.

Domestic public opinion polling gives a better picture of the perception of the threat posed by terrorism among respondents in Poland and Spain. In Poland, we may come across public opinion polls addressing the issue of terrorism and security as a general proposition, while in Spain these polls discuss terrorism and political radicalism in the form of Islamic extremism, which makes it difficult to compare the two countries. Additionally, one may be surprised by the fact that in Spain there is a lack of studies concerning feelings about security or assessments of the degree to which state authorities and institutions are prepared to counteract terrorist attacks. A small number of polls have been carried out by the public think tank Real Insituto Elcano, but none by the most prestigious polling institution Centro de Investigaciones Sociológicas (CIS).

In Poland, reports of studies by CBOS inform us that in 2010, 32\% of respondents felt that there was a real threat of terrorism in Poland, while in 2013 it was $46 \%$, and in 2015 the number reached $53 \%$. At the same time, the number of respondents who felt that the terrorist threat was overstated or non-existent dropped: in 2010 it was 30\% and 26\%, in $201328 \%$ and $24 \%$, and in 2015 it was $22 \%$ and $8 \%$. Thus, in comparing the growth in the perception of the terrorist threat, one may risk the conclusion that successive changes in strategic documents concerning security may be correlated with it to some degree.

Graph 2: Views on the subject of the terrorist threat in Poland during the years 2010-2015 (in \%)

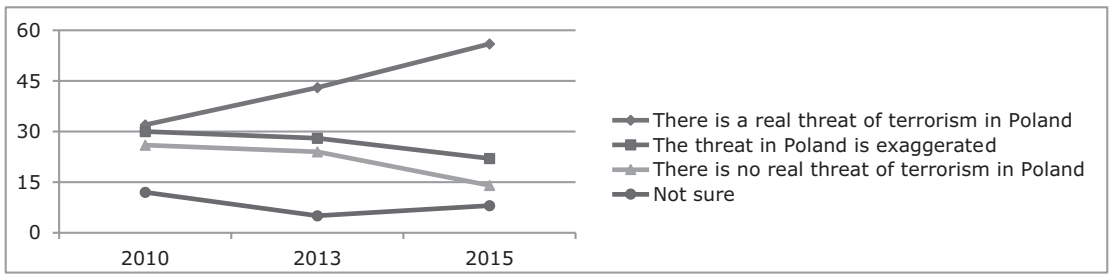

Source: Centrum Badań Opinii Społecznej (CBOS), Zagrożenie terroryzmem, no. 50/2015, Warsaw April 2015, p. 1-2.

*Which response best matches your feelings about terrorism in Poland? 
However, when we review responses to the question "Do you personally fear terrorist attacks or not?" in other studies conducted by CBOS, this tendency does not repeat itself. When analyzing the results of studies carried out on ten separate occasions in the period 2001-2015, we may say that the personal perception of a threat on the part of respondents remains at a constant level. In $2001,39 \%$ of those polled responded that they were afraid of terrorist attacks, while in 2015 this number was $41 \%$. It is worth adding that in 2010 and 2013 Poles felt the safest, with $25 \%$ and $26 \%$, respectively, in fear of such a threat, whereas in the years 2003, 2004 and 2005 the largest number of respondents expressed fear of terrorist attacks, with percentages in those years of 52\%, $64 \%$ and $56 \%$. Such significant growth in the perception of the threat of terrorist attacks should most likely be associated with attacks taking place at the time around Europe.

Graph 3: Personal fears of Poles regarding terrorist attacks in the years 2001-2015 (in \%)

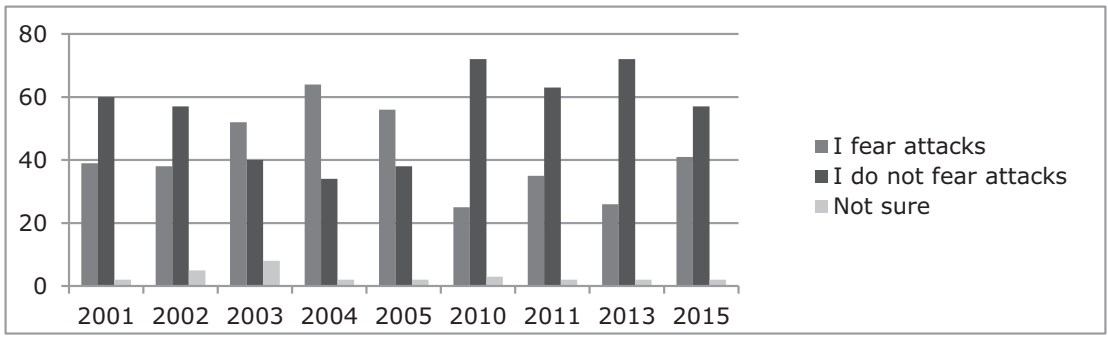

Source: Centrum Badań Opinii Społecznej (CBOS), Zagrożenie terroryzmem, no. 50/2015, Warsaw April 2015, p. 2.

*Are you personally afraid of terrorist attacks or not?

We can therefore observe the absence of correlation between the results of studies on the threat of terrorism facing the Polish state and those examining personal fears of terrorist attacks. There is a greater degree of cohesion between the results of studies concerning the feeling of security and those concerning the personal perception of terrorist threats. Summarizing responses to the question of whether Poland is a country where one may live safely, a growth tendency can be observed, and thus over the preceding few years respondents have responded positively to that question with increasing frequency. Analysis of graph no. 4 allows us to observe that Poles perceive their country as becoming more and more safe. In 2001 , only $18 \%$ felt that Poland was a country where one could live safely, while $81 \%$ expressed the opposite opinion. However, in 2014 these proportions were 
exactly reversed, as $70 \%$ of respondents claimed that Poland was a safe country, while only $28 \%$ declared different position.

Graph 4: Evolution of the perception of safety in Poland over the period 2001-2014 (in \%)

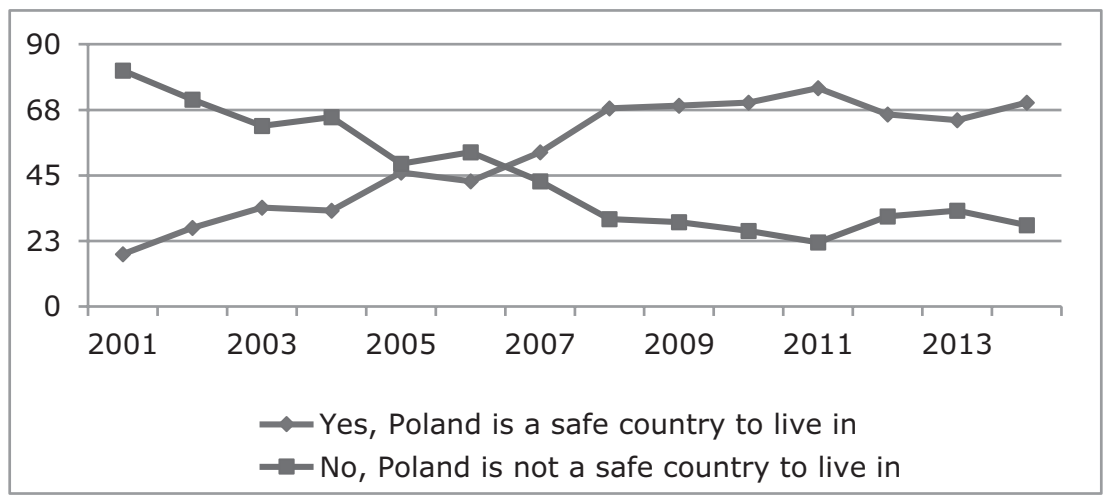

Source: Centrum Badań Opinii Społecznej (CBOS), Bezpieczeństwo publiczne, BS/63/2013, Warsaw May 2013, p. 3; Centrum Badań Opinii Społecznej (CBOS), Opinie o bezpieczeństwie narodowym, no. 18/2014, Warsaw February 2014, p. 1.

*In your opinion, is Poland a safe country to live in?

These results demonstrate that over the last 14 years, Poles' feeling of safety and security has grown. This may be the result of a wide range of factors, but there can be no doubt that if Poles perceived a large danger of terrorist attack, they would not feel so safe. All the more so when considering that in successive opinion polls, they do not provide a favorable assessment of the preparations of Polish authorities and state institutions to prevent terrorist attacks. In 2013, 28\% of respondents declared that Polish authorities and institutions are well prepared (total of responses "strongly agree" and "agree"), while in 2015 this number was even lower, reaching 26\%. During the same years, 58\% and 55\%, respectively, were of the opinion that they were not well prepared (total of responses "strongly disagree" and "disagree"). 
Graph 5: Opinions of Poles concerning the preparation of Polish authorities and state institutions to prevent terrorist attacks in Poland in the years 2013 and 2015 (in \%)

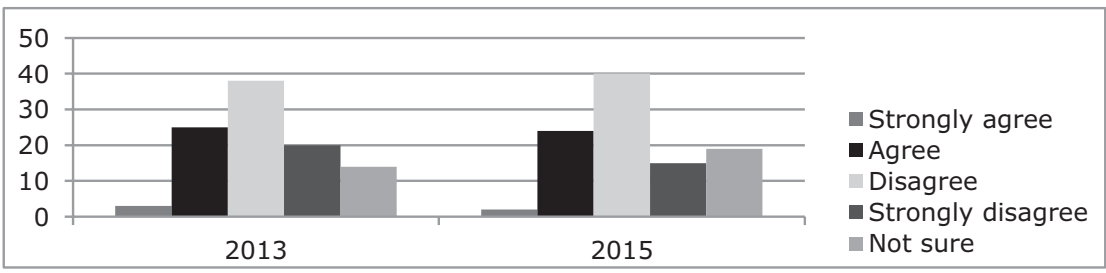

Source: Centrum Badań Opinii Społecznej (CBOS), Zagrożenie terroryzmem, no. 50/2015, Warsaw April 2015, p. 4.

*Do you agree that Polish authorities and state institutions are well prepared to prevent terrorist attacks in Poland?

As has already been mentioned, in Spain we may only find fragmentary research on the subject of perception of the threat posed by terrorism and political radicalism. In the period 2004-2011, public opinion polling conducted by Real Instituto Elcano contained a question asking respondents to declare the greatest threats, including international terrorism, to Spain's strategic interests. Spanish respondents were uniform in their assessment of the significance of the terrorist threat (graph no. 6). When adding together responses indicating that this is a "very serious threat" or "serious threat," it turns out that in the years 2002-2015 the percentage of such responses oscillated between $84 \%$ and $96 \%$ (in 2002: 85\%, 2003 95\%, 2004 90\%, 2005 and 2006 95\%, 2007 93\%, 2008 81\%, 2009 92\%, 2010 96\%, 2011 94\%, 2012 85\%, 2013 84\%, 2014 84\%, 2015 92\%). The results of this poll allow us to state with full confidence that the threat of terrorism is perceived as a significant one in Spain. 
Graph 6: Social perception of the threat of terrorism to Spain's strategic interests in the years 2002-2015 (\%)

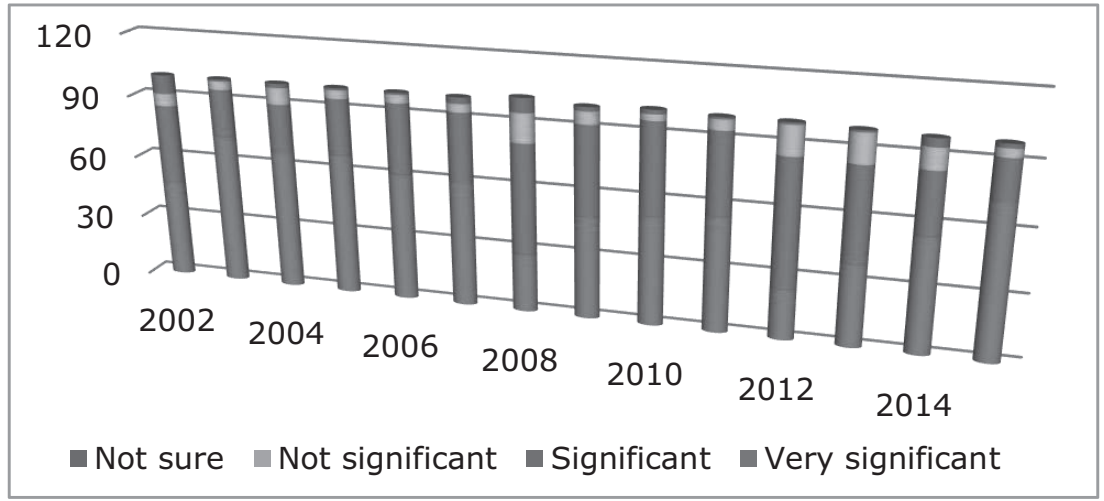

Source: Author's analysis on the basis of Barómetro del Real Instituto Elcano (BRIE) from November 2002, November 2003, March 2004, February 2005, Juny 2006, June 2007, June 2008, July 2009, March 2010, March 2011, April 2012, February 2013; July 2014, June 2015, available at http://www.realinstitutoelcano.org/, accessed 1 February 2016.

The situation is similar with the results of studies concerning the perception of the threat posed by Islamic fundamentalism (graph 7). Also here, the number of respondents pointing to such a threat is very high; however, it is slightly lower than in the case of international terrorism. In 2002, 68\% of respondents declared that this threat was "very significant" or "significant," while in subsequent years this number was $80 \%, 73 \%, 87 \%, 88 \%, 84 \%, 91 \%, 84 \%$ and $78 \%$. Thus, in the opinion of Spanish society, the level of the perception of threats posed by terrorism and Islamic fundamentalism is very high. This is consistent with the Ministry of Internal Affairs announcing in 2015 that it was raising the terrorist attack threat indicator from 3 to 4 , and thus the second-highest level on the scale, which was also captured in the Plan for Counter-terrorism Prevention and Protection (Plan de Prevención y Protección Antiterrorista). ${ }^{55}$

55 J. A. Rodríguez, Los niveles de alerta antiterrorista en España y qué suponen, "El País" 26.06.2015, available at http://politica.elpais.com/politica/2015/06/26/actualidad/1435333317_728405.html, accessed 16 February 2016. 
Graph 7: Social perception of the threat posed by Islamic fundamentalism for Spain's strategic interests in the years 2002-2015 (\%)

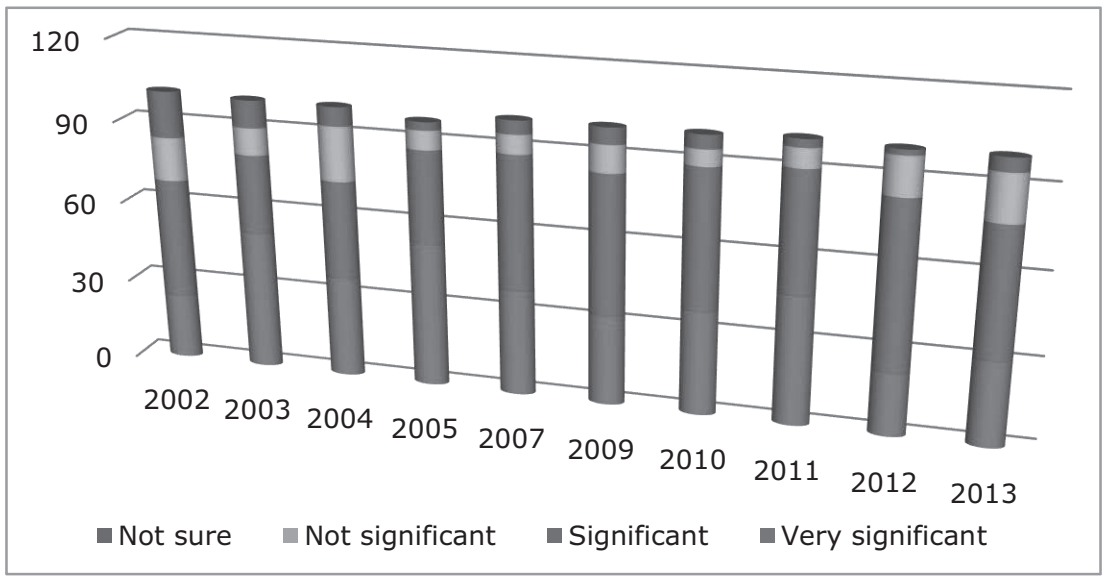

Source: Author's analysis based on Barómetro del Real Instituto Elcano (BRIE) from November 2002, November 2003, March 2004, February 2005, June 2007, July 2009, March 2010, March 2011, April 2012 February 2013, available at http://www.realinstitutoelcano.org, accessed 1 February 2016.

The results cited above are also consistent with successive studies conducted by Real Insituto Elcano concerning the threat of terrorism coming from the ETA, and international terrorism, implicitly understood as Islamic. On the basis of their results, it can be observed that in the years following the March $11^{\text {th }}, 2004$ attack, respondents indicated international terrorism as the type posing the greatest threat to their safety; in 2004, the percentage of people who felt so was $45 \%$, in 2005 it was 30\%, in 2006 as much as 53\%, in $200731 \%$, after which this number declined in 2008 and 2009 to $15 \%$, to again grow in 2010 to $24 \%$, and in 2011 it was $34 \%$. At the same time, responses point to terrorism from the ETA fluctuated; in 2004 they accounted for $15 \%$, in 2005 it was 30\%, in $200627 \%$, in $200724 \%$, in $200823 \%$, in $200934 \%$, in 2010 45\%, and in $201138 \%$. Also, in the case of answers indicating both types of terrorism, it is difficult to discover any universalities as in 2004 there was a total of $38 \%$ such responses, in $200527 \%$, in $200620 \%$, in 2007 $43 \%$, in $200860 \%$, in $200949 \%$, in $201028 \%$ and in $201126 \%$. However, if we add the category "both types of terrorism are a threat," in respect of international terrorism we obtain an average of $67 \%$, while for terrorism from the ETA it is $66 \%$. Thus, what we can conclude from the data presented is that terrorism by the ETA continues to be perceived as a threat to security, as does international terrorism. It is worth mentioning here that this type of survey was last conducted in 2011, 
when ETA announced it was laying down its arms. The absence of attacks by ETA in recent years, accompanied by the increased activities of Islamic fundamentalists, may give rise to different results.

Graph 8: Evolution of the assessment of the terrorist threat from ETA and international terrorism in the years 2004-2011 (in \%)

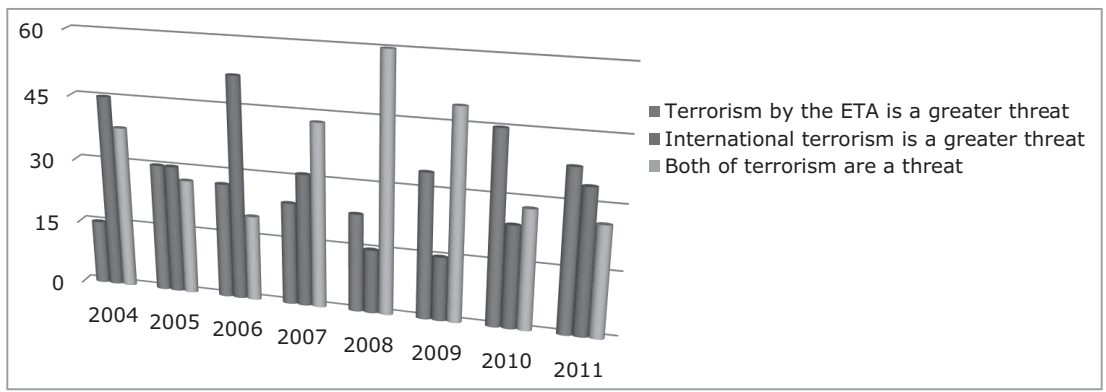

Source: Author's analysis on the basis of Barómetro del Real Instituto Elcano (BRIE) from June 2004 February 2005, June 2006, December 2007, July 2008, March-April 2009, March 2010, March 2011, available at http://www.realinstitutoelcano.org, accessed 1 February 2016.

*Which threat is greater, that from the ETA, or that from international terrorism?

Thus, in the case of Eurobarometer results, it is not easy to precisely determine the degree to which people feel the threat of terrorism, considering the specificity of the study being described and taken together with the outbreak of the economic crisis. In respect of Poland, this task is somewhat easier, for terrorism has not been and is not the primary problem facing Poland in the opinion of respondents. As for the other results from Poland, apart from the study concerning respondents' views on the threat of terrorism in Poland, the remaining ones indicate that the sense of this threat is low. Furthermore, even in the case of studies regarding opinions on the subject of the terrorist threat in Poland, the highest percentage of respondents (in 2015) was recorded at a level of 53\%, while in Spain similar questions received scores of $84 \%$ to $96 \%$ in the years $2002-2015$. In the case of Spain, all of the results from domestic public opinion polls are consistent. There is a very high sense of the threat from terrorism and political radicalism in public opinion, but this sense remains at a stable level and is not growing.

\section{Conclusion}

Terrorism and radicalism are among the factors shaping security strategies in Poland and Spain. Considering the far more significant threat posed by these 
phenomena in Spain than in Poland, they occupy a more important position in the strategic planning of the former country, and more space is devoted to them in strategic documents. Terrorism is listed in Spanish documents as one of the primary threats, in both the domestic and the international dimension, while the issue of terrorism by the ETA would seem to be resolved for the moment, as opposed to Islamic terrorism, which is growing in prominence on a global scale. In Poland, the far lesser threat of terrorism means that this issue occupies a much less prominent place in security strategies. It is listed alongside other types of threats, and generally linked to them. In the case of Poland, dangers coming from terrorism are primarily perceived in categories of citizens staying in unstable regions or soldiers participating in missions abroad, but not for the territory of Poland itself. Thus we may say that the first of the tested hypotheses is confirmed, considering the greater threat of terrorism and political radicalism in Spain compared to Poland, each of these phenomena exert a greater influence on the contours of security strategies in Spain than in Poland.

It is also relatively simple to take note of the impact of external factors on amendments to both countries' security strategies, such as membership in international organizations, these organizations' activities in the international sphere, relations with the USA, and, to a lesser extent, trends in the legislation of the region's most influential states. These influences are similar in both of the countries under analysis. Changes in the strategic conceptions of the NATO or the EU also exert a comparable impact on the security policies of Poland and Spain. Some differences result from geographical location and different neighboring countries, which lead to the emphases in strategies also being different - relations with Russia are key for Poland, while Spain is most concerned with the situation in the Mediterranean basin. However, cyberthreats, inherently of a global nature, exert similar influences on both states. Energy security policies also exhibit some shared characteristics - both states are importers of energy resources. Another hypothesis has thus been confirmed, that the impact of external factors on the contours of strategic documents addressing terrorism and radicalism will be comparable in Poland and in Spain.

As for dependencies between changes in strategic documents concerning national security and growing fears of the threat of terrorism and radicalism among citizens of Poland and Spain, they are not so obvious. The hypothesis that changes in legal regulations concerning terrorism and radicalism are correlated with public opinion polling results to a greater extent in Spain than in Poland, owing to the far greater perception of the threat of terrorism in the former country, is only partially true. In respect of Poland, we cannot identify a dependency between changes in strategic documents addressing national security and growth in the perception 
of the terrorist threat, as the feeling at the personal level of being threatened by terrorism has remained stable for years; this does not, therefore, explain the changes to strategic documents that have been made. Thus, Polish security strategies, the Strategy for Development of a National Security System, the White Paper on National Security of Poland, the National Anti-terrorist Program, and the Cybersecurity Doctrine were not drafted as a result of terrorism being perceived as among the greatest challenges facing the Polish state. As for Spain, the feeling of threat from terrorism and political radicalism in the form of Islamic extremism has grown to a small extent, which may be more indicative of a correlation between the results of public opinion polling and changes in Spanish legislation.

\section{References}

R. Alonso Pascual, Ideologías radicales y no democráticas como potenciadores de riesgo para la seguridad nacional, "Cuaderno de Estrategia", Instituto Español de Estudios Estratégicos, no. 159, 2013, pp. 229-268, available at http://www. ieee.es/Galerias/fichero/cuadernos/CE_159_Potenciadores_de_Riesgo.pdf, accessed 1 February 2016.

Biała Ksiega Bezpieczeństwa Narodowego Rzeczypospolitej Polskiej 2013, Biuro Bezpieczeństwa Narodowego, Warszawa 2013, available at http://www.ank. gov.pl/komunikaty/2013/07/03/biala-ksiega-bezpieczenstwa-narodowego-rp, accessed 1 February 2016.

Doktryna Cyberbezpieczeństwa Rzeczypospolitej Polskiej, Biuro Bezpieczeństwa Narodowego, Warszawa 2015, available at https://www.bbn.gov.pl/ftp/dok/01/ DCB.pdf, accessed 1 February 2016.

F. Carrión, El IS advierte a España que pagará muy caro la expulsión de los musulmanes de Al Andalus, "El Mundo" 31.01.2016, available at http://www.elmundo.es/internacional/2016/01/31/56adefc1268e3e5d0d8b4580.html, accessed 1 February 2016.

Centro de Investigaciones Sociológicas (CIS), Barómetro de Abril 2015, Estudio no. 3080, available at http://www.cis.es/cis/export/sites/default/-Archivos/Marginales/3080_3099/3080/es3080mar.pdf), accessed 8 February 2016.

Centro Superior de Estudios de la Defensa Nacional (CESEDEN), Hacía una Estrategia de Seguridad Nacional para España, Madrid 2009, available at http:// www.defensa.gob.es/ceseden/Galerias/destacados/publicaciones/docSegyDef/ ficheros/025_HACiA_UNA_ESTRATEGIA_DE_SEGURIDAD_NACIONAL_PARA_ESPANA.pdfm, accessed 8 February 2016.

Centrum Badań Opinii Społecznej (CBOS), Zagrożenie terroryzmem, no. 50/2015, Warsaw April 2015, p. 2. 
Centrum Badań Opinii Społecznej (CBOS), Bezpieczeństwo publiczne, no. BS/63/2013, Warsaw May 2013.

Centrum Badań Opinii Społecznej (CBOS), Opinie o bezpieczeństwie narodowym, no. 18/2014, Warsaw February 2014.

Directiva de Defensa Nacional, 2004, Gobierno de España, available at http:// www.centredelas.org/images/stories/adjunts/510_ddn_2004.pdf, accessed 4 February 2016.

Directiva de Defensa Nacional 2008, Gobierno de España, available at http:// www.armada.mde.es/ArmadaPortal/ShowBinaryServlet?nodePath $=/ \overline{B E A \% 20}$ Repository/Desktops/Portal/ArmadaEspannola/Pages/documentacion_reglamentos/07_directiva_defensa_nacional/01_directiva_defensa_nacional_es/ doc_01_directiva_defensa_nacional08//archivo, accessed 12 February 2016.

Directiva de Defensa Nacional 2012, Presidencia del Gobierno, available at http:// www.defensa.gob.es/Galerias/defensadocs/directiva-defensa-nacional-2012. pdf, accessed 8 February 2016.

Estrategia de Ciberseguridad Nacional 2013, Presidencia del Gobierno, available at http://www.lamoncloa.gob.es/documents/20131332estrategiadeciberseguridadx.pdf, accessed 8 February 2016.

Estrategia de Seguridad Energética Nacional 2015, Presidencia del Gobierno, available at http://www.lamoncloa.gob.es/serviciosdeprensa/notasprensa/ Documents/ESTRATEGIA\%20DE\%20SEGURIDAD\%20ENERGETICA\%20 NACIONAL\%20(WEB).pdf, accessed 1 February 2016.

Estrategia de Seguridad Marítima Nacional 2013, Presidencia del Gobierno, available at http://www.ieee.es/Galerias/fichero/OtrasPublicaciones/Nacional/Estrategia_Seguridad_Maritima_Nacional_2013.pdf, accessed 8 February 2016.

Estrategia de Seguridad Nacional 2013: Un proyecto compartido, Presidencia del Gobierno, available at http://www.lamoncloa.gob.es/documents/seguridad 1406connavegacionfinalaccesiblebpdf.pdf, accessed 8 February 2016.

Estrategia Española de Seguridad 2011: Una responsabilidad de todos, Gobierno de España, available at http://www.realinstitutoelcano.org, accessed 8 February 2016.

European Commission, Standard Eurobarometer: no 63, May 2005; no. 65 March 2006; no. 67, April 2007; no. 69, March 2008; no. 71, June 2009; no. 73, May 2010; no. 75, May 2011, no. 77, May 2012; no. 79, May 2013; no. 82, November 2014; no. 84, November 2015, available at http://ec.europa.eu/COMMFrontOffice/PublicOpinion/index.cfm/Survey/index\#p=1\&instruments=STANDARD, accessed 8 January 2016.

M. A. Franco García, De las Directivas de Defensa Nacional a la Estrategia de Seguridad Nacional: tendencia a la integración de capacidades cívico-militares 
en el ámbito marítimo, "Revista del Instituto Español de Estudios Estratégicos" no. 3, 2014.

Instituto Español de Estudios Estratégicos (IEEE), 2010, El contexto de elaboración de la Estrategia Española de Seguridad, available at http://www.ieee.es/ Galerias/fichero/2010/DA-IEEE_02-2010_EL_CONTEXTO_DE_ELABORACION_DE_LA_ESTRATEGIA_ESPANOLA_DE_SEGURIDAD.pdf, accessed 1 February 2016.

Instituto Español de Estudios Estratégicos, 2011, Análisis comparativo de la Estrategia Española de Seguridad "Una responsabilidad de todos», available at http://www.ieee.es/Galerias/fichero/docs_analisis/2011/DIEEEA17_2011EstrategiaEspanolaSeguridad.pdf, accessed 1 February 2016.

Instituto Español de Estudios Estratégicos, La Directiva de Defensa Nacional 2012, available at http://www.ieee.es/Galerias/fichero/docs_analisis/2012/ DIEEEA35-2012_DDN_IEEE.pdf, accessed 1 February 2016.

A. Jagnieża, Nowa Strategia Bezpieczeństwa Narodowego w obliczu kremlowskiego egzaminatora, Defence24 2014, available at http://www.defence24.pl/148404,-nowa-strategia-bezpieczenstwa-narodowego-w-obliczu-kremlowskiego-egzaminatora, accessed 8 January 2016.

P. Kmiecik, Nowastrategia.org.pl, Analiza krytyczna strategii rozwoju systemu bezpieczeństwa narodowego $R P$ do 2022 roku, 2015, available at http://www. nowastrategia.org.pl/analiza-krytyczna-srsbn/, accessed 8 February 2016.

S. Koziej, A. Brzozowski., 25 lat polskiej strategii bezpieczeństwa, „Bezpieczeństwo Narodowe" II, no. 30, 2014.

M. Laborie Iglesias, La Estrategia de Seguridad Nacional (Mayo 2013), Documento Análisis de Instituto Español de Estudios Estratégicos, no. 34/2013, 2014, p. 2, available at http://www.ieee.es/Galerias/fichero/docs_analisis/2013/ DIEEEA34-2013_EstrategiaSeguridadNacional-2013_MLI.pdf, accessed $8 \mathrm{Fe}-$ bruary 2016.

Libro Blanco de Defensa 2000, Ministerio de Defensa, available at http://www. defesa.gov.br/projetosweb/livrobranco/arquivos/pdf/Espanha\%202000.pdf, accessed 15 February 2016.

D. López Garrido, "El País" 10.08.2012, available at http://elpais.com/elpais/2012/08/07/opinion/1344351717_982529.html, accessed 8 February 2016.

L. Mestres, The long road to Spanish security strategy, Notes Internacionals CIDOB, no. 39, 2011.

Real Instituto Elcano, Barómetro del Real Instituto Elcano (BRIE): November 2002; November 2003; March 2004; February 2005; June 2006; June 2007; December 2007; June 2008; July 2008; March-April 2009; March 2010; March 2011; April 
2012; February 2013; July 2014; June 2015; available at http://www.realinstitutoelcano.org, accessed 1 February 2016.

Revisión Estratégica de la Defensa 2003, Ministerio de Defensa, available http:// www.defensa.gob.es/Galerias/defensadocs/revision-estrategica.pdf, accessed 8 February 2016.

J. A. Rodríguez, Los niveles de alerta antiterrorista en España y qué suponen, "El País" 26.06.2015, available at http://politica.elpais.com/politica/2015/06/26/ actualidad/1435333317_728405.html, accessed 16 February 2016.

T. Smura, Szczyt NATO w Newport - powrót do podstaw, Fundacja Pułaskiego, Defence 24 2014, available at http://www.defence24.pl/122717,szczyt-nato-wnewport-powrot-do-podstaw, accessed 18 February 2016.

Strategia bezpieczeństwa narodowego Rzeczypospolitej Polskiej 2003, Rada Ministrów Rzeczypospolitej Polskiej, accessed 8 February 2016.

Strategia bezpieczeństwa narodowego Rzeczypospolitej Polskiej 2007, Rada Ministrów Rzeczypospolitej Polskiej, available at http://www.msz.gov.pl/resource/7d18e04d-8f23-4128-84b9-4f426346a112, accessed 8 February 2016.

Strategia bezpieczeństwa narodowego Rzeczypospolitej Polskiej 2014, Rada Ministrów Rzeczypospolitej Polskiej, available at https://www.bbn.gov.pl/ftp/ SBN\%20RP.pdf, accessed 8 February 2016.

Strategia rozwoju systemu bezpieczeństwa narodowego Rzeczypospolitej Polskiej 2022, Rada Ministrów Rzeczypospolitej Polskiej, 2013, available at https:// www.bbn.gov.pl/ftp/dok/01/strategia_rozwoju_systemu_bezpieczenstwa_narodowego_rp_2022.pdf, accessed 8 February 2016.

Narodowy Program Antyterrorystyczny na lata 2015-2019, Uchwała nr 252, Rada Ministrów Rzeczypospolitej Polskiej 2014, available at www.monitorpolski.gov. pl/mp/2014/1218/M2014000121801.pdf, accessed 8 February 2016.

J. Urbanowicz, 17 Polaków zginęto $z$ rąk terrorystów islamskich podczas globalnej wojny $z$ terroryzmem, Polskie Radio 2015, available at http://www.polskieradio.pl/5/3/Artykul/1402579,17-Polakow-zginelo-z-rak-terrorystow-islamskich-podczas-globalnej-wojny-z-terroryzmem, accessed at January 2016. 


\section{José María Blanco Navarro \\ The Fight against Jihadism in Spain Special Mention to the Spanish Civil Guard}

\section{Introduction: Jihadism, A Global Phenomenon}

The data related to the year 2014 published by the Country Reports on Terrorism, from the State Departed of the United States, and the database included in the National Consortium for the Study of Terrorism and Responses to Terrorism START, show a great increase in the number of terrorist attacks that took place around the world in that year. The number of attacks during the last two years has increased, reaching the levels from the years 2006 and 2007, with a death toll higher than 30.000 each year. The data partly explain the situation: an accelerated deterioration of the situations in Iraq and Afghanistan after the long military interventions, the rise and push of Daesh and the huge increase of attacks and lethality of Boko Haram in Nigeria.

To be sure, jihadism is widely considered as the main security threat, but it needs to be put into context: in Iraq, Pakistan, Afghanistan, India, Nigeria, and Syria it is a daily reality. In Western countries, in turn, it is an important threat that is not normally produced.

Different questions help to understand the recent situation: a threat increasingly diversified after the break of the Islamic State of Iraq and the Levant (ISIS) from Al Qaeda and the proliferation of local groups, the momentum of Daesh and its capacity for attracting the youth around the world, specially after the declaration of the Caliphate in Mosul, a multiplicity of endless conflicts in extreme fragile states, an intensification of the conflict between Sunni and Shia Muslims, the fragmentation of Islam itself with growing extremist visions, the benefit from new telecommunication technologies - such as the Internet, the darknet or apps - which increase the propagandistic effect of the message and the actions of those groups, the creation of real "terror armies" in the conflict zones, with the mobilizations of foreign fighters who support Daesh and rise of their strategic and tactic capacities, growing connection between terrorist and organized crimes groups who live together in the same conflict environments, the rise of homegrown terrorism in Western countries and evolution and adaptation of the modus operandi with an important emulation effect 
(use of firearms, attacks against soft targets, beheadings, vehicle related actions). These tendencies will remain in the medium term. ${ }^{1}$

All these elements, and others of local character, imply for Western nations an important increase of the terrorist threat and the need of adapting the counterterrorism operations to the metamorphosis the threat has suffered.

Before focusing on Spain, we need to understand how the situation in Europe is evolving. Freedom of movement inside the European Union implies that the threat of any of its states could perfectly expand to the rest, which proves the need of shared measures.

The Paris terror attacks in January and November, the police operation in Belgium in which two alleged terrorists were killed, the attacks registered in Copenhagen in February, together with the constant police operations and dismantling of presumed complots against multiple European cities, have raised all the alarms during 2015.

Within Europe, the effects of the Paris terror attacks are evident and clearly negative. The impacts are not only the personal and material damages produced directly during the attacks, but also the increase of the social terror, which has contributed to a social polarization - the rise of xenophobic actions and Islamophobia, as well as anti-Semitism, with several attacks to mosques or refuge centers, or the support of actions of groups such as PEGIDA and its spread along Europe.

The effects have also opened the tricky debate between freedom and security and divided the Western vision related to the limits of the freedom of speech, especially when these expressions offend concrete communities. It has fostered the common complaint against the security forces and intelligence services, because of the retrospective clarification bias based on drafting an analysis afterwards. It has also promoted the beginning of the adaptation process of new legislative and police measures, but perhaps without pointing out sufficiently the need of not overreacting to the threats. The paralysis of a city such as Brussels and the prolonged state of emergency declared in France after the attacks represent a victory of terrorism that has determined the lifestyle in Europe and imposed limitations on our rights and freedoms.

1 J. M. Blanco, J. Cohen, The future of counter-terrorism in Europe. The need to be lost in the correct direction, "European Journal of Future Research" no. 1 (2), 2014, available at http://link.springer.com/article/10.1007\%2Fs40309-014-0050-9, accessed 20 December 2015. 


\section{Analysis of the Threat in Spain}

\subsection{Factors involved}

After the attacks of March $11^{\text {th }}, 2004$, Spain redoubled efforts to fight against jihadist terrorism, which had previously used Spain as a logistics centre and a place to find shelter. The most important historical antecedent was the attack on the restaurant "El Descanso" in 1985, near the US military base of Torrejon de Ardoz, in which 18 people were killed.

In order to analyze the existent threats for Spain, we need to identify a series of factors, which could be quantified, or at least, susceptible of being measured. They should allow fixing the needed references to determine if the threat is rising or lowering. In that sense, we could distinguish a range of structural and circumstantial aspects, following the approach of Reinares, ${ }^{2}$ who analyzed the dimension of the threat in different European countries.

2 F. Reinares, ¿Por qué el terrorismo yihadista afectará más a unos países europeos que a otros?, Real Instituto Elcano 2011, available at http://www.realinstitutoelcano.org/ wps/portal/rielcano/contenido?WCM_GLOBAL_CONTEXT=/elcano/elcano_es/ zonas_es/ari82-2011, accessed 20 December 2015. 
Figure 1: Structural and circumstantial factors in assessing the threat

\begin{tabular}{|c|c|}
\hline \multirow[t]{3}{*}{ Structural } & $\begin{array}{l}\text { History } \\
\text { - Al-Andalus } \\
\text { - Previous experiences with terrorist groups, attacks and counter- } \\
\text { terrorism policies }\end{array}$ \\
\hline & $\begin{array}{l}\text { Geography } \\
\text { - Proximity to conflict spots. } \\
\text { - Ceuta and Melilla } \\
\text { - Spain, link between continents. }\end{array}$ \\
\hline & $\begin{array}{l}\text { Social-Demography } \\
\text { - Communities and minorities } \\
\text { - Multiculturalism and integration } \\
\text { - Fragile Urban Environments }\end{array}$ \\
\hline \multirow[t]{7}{*}{ Circumstantial } & Threats and mentions to the Spanish state in the jihadist propaganda. \\
\hline & Counter terrorism efforts in Spain \\
\hline & Spanish presence in the international sphere. \\
\hline & $\begin{array}{l}\text { Level of acceptance of the Muslim communities and level of social } \\
\text { polarization. }\end{array}$ \\
\hline & The number of displaced fighters and returnees from the conflict areas \\
\hline & Specific grievances. Use of veil, caricatures or policies toward mosques. \\
\hline & $\begin{array}{l}\text { Opportunity circumstances. Closeness to the elections, ephemeris, } \\
\text { religious celebrations (Christmas), celebration of big international } \\
\text { events. }\end{array}$ \\
\hline
\end{tabular}

Source: Author's concept.

Among the first set of factors, historical, geographical and social-demographical aspects continue to determine greatly the current threat.

The claim of Al-Andalus, or the mention of the cities of Ceuta and Melilla, is a constant in the jihadist literature. Al Andalus represents the splendor of Muslim power and culture and the great future desire. The name describes parts of Spain that were occupied by Muslims between 711 and 1492. It constituted a province of the Umayyad Caliphate, the Emirate of Cordoba (750-929) and the Caliphate of Cordoba (929-1031).

Taking into account the historical aspects, we need to consider previous attacks and antiterrorist measures in the country, even though the past cannot be used as a reliable source to predict the future. Spain has fought for many years against a cruel terrorist group (ETA) and has demonstrated that the tools of the rule of law can end this scourge. The domestic terrorist group Basque Fatherland and Liberty (ETA) has not launched any attacks since it announced a "definitive cessation of 
armed activity" in October 2011, although the group had not formally disbanded or given up its weapons arsenal by the end of 2015 .

But jihadist terrorism is a different phenomenon, with new features, which have forced Western states to adapt legal and judicial structures and the actions of law enforcement agencies. Presently, our societies face a more international and diffuse threat.

At the same time, however, the proximity to North Africa, which sets up Spain as the main entrance to Europe, is a differential aspect against the backdrop of other European nations. As Reinares claims, the distance to jihadist centers is an essential aspect to take into account. The existence of close conflict spots, such as Libya, Sahel, or the desire of Boko Haram to play in a greater international dimension after pledging loyalty to the Daesh - this change is shown in the new denomination they have adopted, calling themselves Islamic State in Western Africa - constitute clear and present risks.

In this regard, collaboration with Algeria and Morocco are fundamental for the national security of Spain against the instability of the Sahel, and especially the turmoil in Libya and Tunisia, as well as the connections between the terrorist net in Spain and in Morocco. De la Corte, ${ }^{3}$ analyzing the situation in Ceuta and Melilla, establishes a conceptual framework, suggesting to take into account the proximity to extremist centers, the existence of shared frontiers, the connection between the different migration routes and the terrain.

In the social-demographical aspects, we need to point out the demographic configuration, which could feed the social polarization between communities and minorities, the existence of marginalization and social exclusion, and the creation of urban ghettos. Blanco and Cohen, ${ }^{4}$ in a drug trafficking analysis in Mexico, applied the conceptualization of Sullivan ${ }^{5}$ about the existence of "narcocities," a local application of the concepts of failed or fragile states. In the present

3 L. De la Corte, ¿Enclaves yihadistas? Un estudio sobre la presencia y el riesgo extremistas en Ceuta y Melilla, "Revista de Estudios en Seguridad Internacional" no. 2(1), 2015, pp. 1-34, available at http://www.seguridadinternacional.es/revista/?q=content/\%C2\% BFenclaves-yihadistas-un-estudio-sobre-la-presencia-y-el-riesgo-extremistas-enceuta-y, accessed 20 December 2015.

4 J. Cohen, J.M. Blanco, El crimen organizado y la estabilidad estatal en México, I Congreso de Estudios Militares Granada 2014, available at http://estudiosmilitares.es/ comunicaciones/J\%C3\%A9ssica\%20Cohen\%20Villaverde\%20y\%20Jos\%C3\%A9\%20 M\%C2\%AA\%20Blanco\%20Navarro.pdf, accessed 20 December 2015.

5 J. P. Sullivan, Narco-Cities: Mexico and Beyond, "Small Wars Journal" 31.03 .2014 available at www.smallwarsjournal.com, accessed 20 January 2016. 
paper, we shall apply this concept to specific zones of cities and regions in which we can talk about "fragile urban environments." In this regard, we may think of examples of districts such as Príncipe Alfonso in Ceuta, Molenbeek in Brussels, or some banlieuves in the suburbs of Paris, although we can also assume that they are subjected to different conditions.

A failed state would be the one which is not capable of providing the basic goods and services to its citizens, which cannot guarantee their security against armed forces, and which, finally, lacks legitimacy, as a great percentage of its elites and society do reject the existing rules. ${ }^{6}$ Following Max Weber, we can describe a failed state as one that does not have the monopoly of the use of force. According to the OECD, a fragile state cannot satisfy the expectations of its citizens or control the changes in the political process. Sullivan ${ }^{7}$ classifies examples of "narco-cities" as communities with extreme violence rates and conflicts due to the actions of different cartels. In their most extreme level, there are several cities with a lack of legitimacy and public power, which is occupied by non-State entities, such us the organized crime groups.

Blanco and Cohen ${ }^{8}$ understand as "fragile urban environments" the districts or zones of regions characterized by the convergence of several of the following aspects: a high inequality rate, great unemployment rates (especially youth unemployment), high percentage of school failure, extreme poverty or deprivation, huge crime rates, difficulties in accessing basic public services - electricity, water, healthcare, education or security provisions - or the complex urbanism which could isolate a part of a city, among others.

We need to avoid the unfair stigmatization of the resident population, which could only create the effect of polarizing the feelings and raising the perception of offense. The majority of the citizens who live in those places assume all the rights and obligations demandable as a part of a citizenship. They are not violent radicals, nor jihadist, and they do not want to travel to Syria. However, there are socio-economic conditions for radicalization processes: employment, infrastructure, social services and development are the means of action. Professor Luis de la Corte, ${ }^{9}$ in a report for

6 C. T. Call, Beyond the failed state: Toward conceptual alternatives, "European Journal of International Relations", US Institute for Peace, Washington 2010.

7 J. P. Sullivan, Narco-Cities...op.cit.

8 J. M. Blanco, J. Cohen, Entornos urbanos frágiles, Diario BEZ, available at http://www. bez.es/617991634/Tras-los-atentados-de-Paris-III.-Entornos-urbanos-fragiles.html, accessed 20 December 2015.

9 L. De la Corte, Actividad yihadista en Ceuta: antecedentes y vulnerabilidades, Real Instituto Elcano 19.06.2007, available at http://www.realinstitutoelcano.org/documentos/ 
the Real Instituto Elcano, suggested a series of measures, in which the ones of local character and socio-political content acquired special relevance.

Among the circumstantial factors to evaluate the threat, the following should be pointed out:

\section{References to Spain in the jihadist propaganda, especially in the cases of direct threat}

Spain continues to appear in the jihadist discourse. Torres summarizes all references to Spain in the jihadist propaganda without taking into account the anonymous declarations, and allowing to distinguish those which claim historical and geographical aspects, from those which call for violent actions. ${ }^{10}$

In the year 2015, the above mentioned author has found 21 references, while in the previous year only 10 references were found.

Figure 2: Spain in the Jihadist propaganda

\section{5}

\section{Evolución de temas por años}

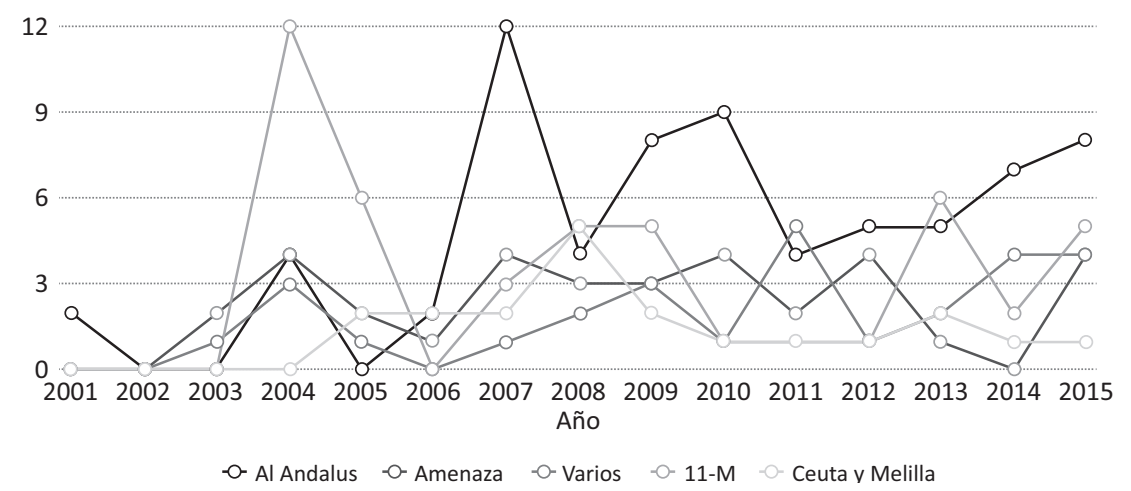

Source: M. Torres, Referencias a España en la propaganda yihadista, available at http://www. seguridadinternacional.es, accessed 20 January 2016.

DT2007/DT28-2007_de_la_Corte_actividades_yihadistas_Ceuta.pdf, accessed 20 December 2015.

10 M. Torres, Referencias a España en la propaganda yihadista, available at http://www. seguridadinternacional.es/?q=es/content/referencias-espa\%C3\%B1-en-la-propaganda-yihadista\#overlay-context=es/content/operaciones-policiales-contra-el-terrorismo-yihadista-en-espa\%25C3\%25B1\%3Fq\%3Des/content/operaciones-policialescontra-el-terrorismo-yihadista-en-espa\%25C3\%25B1, accessed 20 January 2016. 
As the figure shows, most of the mentions are based on Al-Andalus, sometimes as the greater desired goal, and sometimes together with the desire of taking Paris and Roma. However, we can point out two very specific references to Spain. The first one was the call for action of the "brothers" of Melilla, with origins in Al Qaeda in the Islamic Maghreb (AQIM), in which the Spanish Abu al-Nur al Andalusi speaks, but which does not call for action in Spain. The second one was an article titled "The Lone Wolves," published by Al-Khilafah Media Fundation, about future terrorist actions in Madrid, London, and Sydney. Later on, in January 2016, in a new video from Al Qaeda in the Islamic Maghreb, Abu al-Nur al Andalusi threatens Napoli, Rome and Madrid with future explosions.

A video published in November by Wilayat Dayala, threatening France, used Spain as an example, pointing out how Spanish citizens forced the Government against the participation in the war in Iraq.

The evaluation of these communications could also consider the broadcast and the impact of the channel in which they appear. Spain is mentioned three times in Dabiq, the publication of Daesh - on the numbers 7, 8 and 11. It is also referenced on the environment of $\mathrm{Al}$ Qaeda, as Ayman Al Zawahiri speaks about Spain three times: in the jihadist magazine Inspire, in the magazine Resurgence, and in a video of AQIM.

The number of references to Spain has soared in January 2016. Torres has detected the existence of at least nine statements, with explicit mentions to $\mathrm{Al}$ Andalus, Ceuta, Melilla, Canary Islands, Cordoba, Sevilla, Granada and Madrid. ${ }^{11}$

\section{Counter-terrorism efforts}

The number of developed operations and detainees could turn into an indirect indicator of the jihadist activities developed in the country: in terms of recruitment and indoctrination, financing and communication activities, foreign fighters traveling to conflict zones or plans of attacks.

Police operations are also an indicator of violent incidents (there are more attempts, luckily, than performances), susceptible of specific evaluations: the threat does not have the same degree in the disarticulation of a propaganda network as an attack in an advanced process. In 2015, 102 individuals were taken into custodies with Islamic terrorism charges, 75 in Spain and 27 in other States. Since

11 M. Torres, La lucha por liderar el yihadismo magrebí aumenta la amenaza sobre España, Observatorio Internacional de Estudios sobre Terrorismo (OIET), available at http:// observatorioterrorismo.com/terrorismo-internacional/la-lucha-por-liderar-el-yihadismo-magrebi-aumenta-la-amenaza-sobre-espana/d, accessed 20 January 2016. 
the beginning of our last government in December 2011, 177 individuals were detained. Data from 2015 show a great increase over the 46 detainees in 2014, 21 in 2013 or just 8 in 2012, proving the momentum of Daesh and its recruitment, indoctrination and transfer of fighters to the conflict zones. The number of operations has also increased, reaching a maximum of 36, against the 19 registered in 2007, with 8 other additional missions in other countries.

Figure 3: Police operations and arrested people

\begin{tabular}{|c|c|c|c|c|c|c|c|c|c|c|c|c|c|}
\hline & 2004 & 2005 & 2006 & 2007 & 2008 & 2009 & 2010 & 2011 & 2012 & 2013 & 2014 & 2015 & TOTAL \\
\hline $\begin{array}{l}\text { Operations in } \\
\text { Spain }\end{array}$ & 9 & 11 & 9 & 19 & 11 & 10 & 5 & 12 & 5 & 8 & 13 & 36 & 148 \\
\hline $\begin{array}{l}\text { Arrested } \\
\text { people }\end{array}$ & 131 & 92 & 59 & 51 & 62 & 40 & 12 & 17 & 8 & 20 & 36 & 75 & 603 \\
\hline $\begin{array}{l}\text { Operations } \\
\text { in other } \\
\text { countries }\end{array}$ & & & & & & & & & & 1 & 5 & 8 & 14 \\
\hline $\begin{array}{l}\text { Arrested } \\
\text { in other } \\
\text { countries }\end{array}$ & & & & & & & & & & 1 & 10 & 27 & 38 \\
\hline
\end{tabular}

Source: Own analysis on the basis of data from Ministry of the Interior of Spain.

Figure 4: Evolution of operations and arrested people

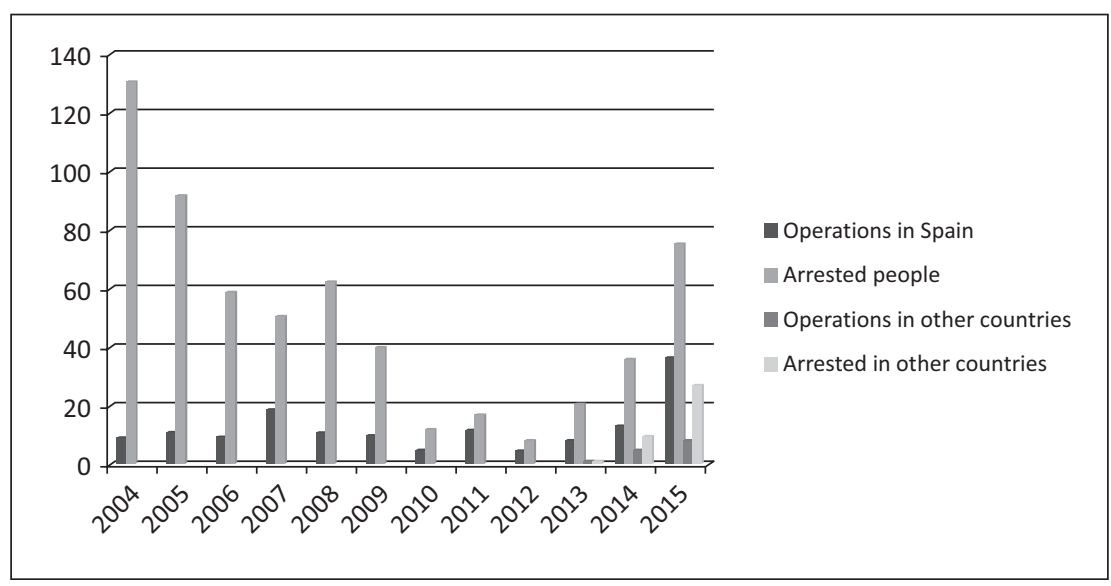

Source: Own analysis on the basis of data from Ministry of the Interior of Spain.

As we shall argue later on, Spain develops an intensive activity in the fight against terrorism in all its forefronts, not only in the police field. 


\section{Number of returnees and displaced combatants}

According to the official information issued by the Ministry of the Interior, there would be approximately 139 people displaced to conflict areas from Spain. At the end of June 2015, 25 were estimated to have returned to Spain. Some of them would have died in Syria, in combats and suicide missions or because of bombings. At the beginning of December 2015, The Soufan Group ${ }^{12}$ estimated between 27.000 and 31.000 people coming from 86 countries to have travelled to Syria and Iraq during the last 18 months in order to join Daesh, and it pointed out that 133 of them came from Spain, a relatively low number compared that of other neighboring countries (1.700 from France, 760 from UK and Germany or 470 from Belgium). It is estimated that around $10-30 \%$ of displaced people, at a global level, could have returned to their home countries.

Furthermore, according to data given by the media in November, 301 people are being investigated by the National High Court, due to their possible relation to recruitment, exaltation, belonging to or collaboration with armed groups.

\section{Spain's action and its international role, especially in conflict countries}

Spain's exterior action in conflicts like those taking place in Syria, Iraq and Libya is currently low, at least in comparison to the main role the country assumed in the meeting of the Azores, which was previous to the war in Iraq, after the meeting of the former president José María Aznar with George Bush and Tony Blair. The jihadist propaganda of the last months, previously mentioned, published the Spanish flag among those of the countries they identify as part of a coalition against ISIS.

\section{Degree of acceptance of Muslim communities, social exclusion or oppor- tunities for social participation, communication lines and representation, Islamophobia, hate crimes}

Exclusion, inequality and marginalization feelings can favor violent radicalization processes. They can be circumstantial situations, but if they are maintained over time and in a specific geographical area, they lead to the creation of "fragile urban areas."

12 The Soufan Group, Foreign Fighters. An Updated Assessment of the Flow of Foreign Fighters into Syria and Iraq, 2015, available at $h t t p: / / s o u f a n g r o u p . c o m / w p$-content/uploads/2015/12/TSG_ForeignFightersUpdate3.pdf, accessed 20 January 2016. 
While Spain's unemployment rate was 21.6\% in September 2015, the Moroccan rate was $60 \%$. Ceuta presents an unemployment rate of $30.6 \%$ and Melilla $31.4 \%$, according to the Labor Force Survey data of the third quarter of 2015. Youth unemployment is even worse, reaching 47.7\% in September 2015 in Spain $(90.35 \%$ in Ceuta or $69.14 \%$ in Melilla).

Additionally, the economic downturn left 720.000 households without any kind of income, according to data of the third quarter of 2015 (in comparison to 740.000 in 2014). 1.470.000 households have all their members unemployed. $22.2 \%$ of the population is in risk of poverty, a number which rises to $44.3 \%$ in Ceuta.

Different studies show how Spain is the state of the Organization for Economic Co-Operationand Development (OECD) in which inequality rose the most (2007-2011). 10\% of the poorest individuals lost a third of their income between 2007 and 2010. The Gini coefficient gives Spain a punctuation of 0.347 in 2015, the second country in inequality matters of Europe, after Latvia.

On December 31, 2014 there were 1.858.409 Muslims living in Spain, which means an increase of $7.2 \%$ in comparison to 2013 numbers, according to the data shown by the Observatory Andalusi ${ }^{13}$ and the Union of Islamic Communities of Spain (UCIDE). More than 40\% come from Morocco. 218.288 are Spanish, approximately $40 \%$ of the total, 400.286 descendants. This means an increase of $26 \%$ of the data of 2013. If we classify them by Autonomous Communities, in Catalonia there are 509.333 Muslims, 298.152 in Andalusia, 274.907 in Madrid and 194.585 in Valencia.

A report of PEW Research ${ }^{14}$ published in 2014 points out that $47 \%$ of Spanish citizens want fewer immigrants, which is a much lower number than that of countries like Italy, France or UK. A report published in 2015 shows that $42 \%$ has a negative perception of Muslims, in comparison to $52 \%$, which has a positive perception. A report of Foundation La Caixa points out that the acceptation of the immigrants in Spain fell from 70\% in 2010 to 57\% in 2012, and that the rejection rose from $10 \%$ to $14 \%$. At the same time, mistrust toward Muslims went from a $23 \%$ to a $26 \%$.

Spain has made progress in the last two years in registering and addressing hate crimes, offering the first statistics since 2013. There were 1.172 hate crimes in 2013 , increasing in $9.6 \%$ in 2014 . In both years, sexual identity or orientation

13 Observatorio Andalusí, Estudio demográfico de la población musulmana, 2015, available at http://observatorio.hispanomuslim.es/estademograf.pdf, accessed 20 January 2016.

14 Pew Research Center, Faith in European Project Reviving, 2015, available at http://www. pewglobal.org/files/2015/06/Pew-Research-Center-European-Union-Report-FINALJune-2-20151.pdf, accessed 20 December 2015. 
were the most common incidences (452 in 2013 and 513 in 2014). 381 racism and xenophobia incidents took place in 2013 and 475 in 2014. Through 2015, the Ministry of the Interior admitted a rise in the data that are being analyzed this year, with $40 \%$ of hate crimes related to Islamophobia.

Figure 5: Hate crimes in Spain

\begin{tabular}{|lrc|}
\hline Hate crimes in Spain & $\mathbf{2 0 1 3}$ & $\mathbf{2 0 1 4}$ \\
\hline Anti-Semitism & 3 & 24 \\
\hline Hate against poor people & 4 & 11 \\
\hline Religious & 42 & 63 \\
\hline Incapacities & 290 & 199 \\
\hline Sexual identity & 452 & 513 \\
\hline Racism / Xenophobia & 381 & 475 \\
\hline TOTAL & 1172 & 1285 \\
\hline
\end{tabular}

Source: Own analysis on the basis of data from Ministry of the Interior of Spain.

\section{Specific grievances perceived. Veil, caricatures}

Several debates have affected other European states, especially France: the use of religious symbols, the Islamic veils in schools or Prophet Muhammad caricatures in satirical magazines like Charlie Hebdo. In Spain, there have been no discussions of such intensity and they have not caused direct or explicit threats as a consequence of that type of issues.

\section{Opportunity criteria}

Terrorism is a random event, where intentions and capacities must converge in order to materialize an attack against the identified vulnerabilities. This convergence might take place whenever and anywhere in the world, as it depends on the decision taken by groups or individuals. The intention might be increased thanks to facts like the celebration of especially important events (general elections, sports or an international summit). In these cases, the desire to attack raises the expectations about the impact it may cause, which is always a part of the terrorist objective.

The model that has been set out allows us to analyze the evolution of the threat and to make a comparison to other neighboring countries. We can thereby see that the level of threat in Spain is lower than in France.

The following chart offers a comparative between Spain and France: 
Figure 6: Threat analysis in Spain and France

\begin{tabular}{|l|l|l|}
\hline Factors & Spain & France \\
\hline Historical factors & $\begin{array}{l}\text { Al Andalus, } \\
\text { autonomous cities of } \\
\text { Ceuta and Melilla }\end{array}$ & $\begin{array}{l}\text { Colonial past, history } \\
\text { of Algeria }\end{array}$ \\
\hline Geographical factors & $\begin{array}{l}\text { Proximity to the } \\
\text { north of Africa }\end{array}$ & $\begin{array}{l}\text { Distance to conflict } \\
\text { focus }\end{array}$ \\
\hline $\begin{array}{l}\text { Demographic factors } \\
\text { - Muslim population } \\
\text { - No of displaced people to conflict zones } \\
\text { - Returnees from conflict zones } \\
\text { - Sized up people or people under special } \\
\text { surveillance }\end{array}$ & $\begin{array}{c}1.858 .09 \\
139\end{array}$ & $\begin{array}{c}4.710 .000 \\
1.400 \\
300 \\
10.000\end{array}$ \\
\hline $\begin{array}{l}\text { Participation in international } \\
\text { operations }\end{array}$ & $\begin{array}{c}\text { Very low current level } \\
\text { High implication, } \\
\text { especially in Syria and } \\
\text { Sahel }\end{array}$ \\
\hline Degree of threat in jihadist propaganda & Medium & High \\
\hline Intensity in anti-terrorist fight & Intense & Extremely intense \\
\hline $\begin{array}{l}\text { Other circumstances: caricatures of } \\
\text { Mahomet, veil, etc. }\end{array}$ & $\begin{array}{l}\text { Low-medium level of } \\
\text { grievance perception }\end{array}$ & $\begin{array}{l}\text { High level: Charlie } \\
\text { Hebdo, debates } \\
\text { about laicism and } \\
\text { multiculturalism, etc. }\end{array}$ \\
\hline
\end{tabular}

Source: Author's concept.

\subsection{Case analysis}

It is of relevance to complement the analysis of objective data presented in the previous sections with an analysis of the profiles, activities and motivations of some of the individuals arrested in the operations which were carried out. The quantitative and qualitative information obtained from this type of analysis can help us to know the phenomenon, but not to entirely understand it.

The information about the last police operations allows us to characterize the current threat:

- Existence of recruitment and indoctrination networks to send people to Syria and Iraq. In spite of the low number of displaced people coming from Spain regarding other countries, it is still the aspiration of some people.

- Coexistence of cells that, regardless of a displacement of some of its members, want to commit an attack in Spain. 
- Existence of groups susceptive of extremist propaganda, with a possible progress of the Salafi movement.

- An evolution of women's role in different lines, not only regarding displacement in order to get married and establish in a territory controlled by Daesh, but also in active recruitment activities.

- A clear change in tendency, with a majority of arrested being Spanish citizens, and the increasing phenomenon of the converted people. A homegrown violent radicalization.

- The existence of links among arrested people and networks or extremists previously arrested. The networks that send combatants connect previous experiences of people already linked to violent extremist opinions with new young candidates to Jihad.

- The existence of a risk that derives both from the return of people that have fought in conflicts and the frustration of those who could not travel to conflict zones, increased by the call from Daesh to act in their own area of origin. International bombings in Syria, the greater control of passengers in the EU and a greater surveillance in Turkish borders can make their journeys more difficult, generating the alternative of moving to other conflict zones, like Libya, or staying in their countries of origin in order to wait for an opportunity.

- The risk that derives from individual actors willing commit a terrorist attack, especially against soft targets.

- The cases of explicit radicalization, and the role of social media in this regard.

- The existing focus in Ceuta, Melilla and Catalonia.

Researches from Reinares and García-Calvo ${ }^{15}$ and Jordan ${ }^{16}$ offer a complete vision of the characteristics of people involved in jihadist plots in Spain and the jihadist militancy in Spain, through the analysis of people condemned and operations developed.

15 F. Reinares, C. García-Calvo, Terroristas, redes y organizaciones: facetas de la actual movilización yihadista en España, Real Instituto Elcano, 2011, available at http://www. realinstitutoelcano.org/wps/portal/web/rielcano_es/contenido?WCM_GLOBAL_ CONTEXT=/elcano/elcano_es/zonas_es/terrorismo+internacional/dt17-2015-reinares-garciacalvo-terroristas-redes-organizaciones-facetas-actual-movilizacion-yihadista-espana, accessed 20 December 2015.

16 J. Jordan, The evolution of the structure of jihadist terrorism in Western Europe: the case of Spain, "Studies in Conflict and Terrorism" no. 37 (8), 2015, pp. 654-673. 


\subsection{Evaluation of the threat and alert level}

Therefore, the threat would be the convergence of objectives, intentions and capacities.

- Objectives. Even though there are no objectives declared a priori, unlike in France with Charlie Hebdo, the emulation effect of other attacks and the orientation toward soft targets (objectives of low protection) make any action possible.

- Intentions. The intention is connected to the desire to commit an attack and the expectations that it causes. The variables mentioned before and the high number of police interventions that have been developed show the existence of the desire. The expectations grow when the attack can generate a higher impact, and attract the attention of mass media: indiscriminate and coordinated attacks, symbolic targets, number of deaths or coincidence with international events.

- Capacities. The capacity is determined by the knowledge needed and resource availability in order to commit an attack. Capacities are present, access to information is easy and resources (basically economic in order to obtain weapons and prepare the necessary logistics: rented housing, vehicles) are available. In any event, carrying out a sophisticated attack, trying to emulate what happened in Paris, increases the cost of the necessary resources, implies a larger group of people and, therefore, makes its development more complex.

The Spanish system has been modified in 2015 and level 4 has been established, considered as high. In the previous months, the existing model for evaluating the threat established an activation level 3, which corresponded to a very high threat alert, implementing the grade of low intensity.

Moreover, the new level of Anti-terrorist Alert has been made public, available on the webpage of the Ministry of the Interior, contributing to transparency and avoiding misunderstandings or circulation of unfounded rumors. 
Figure 7: Terrorism alert level. Ministry of the Interior

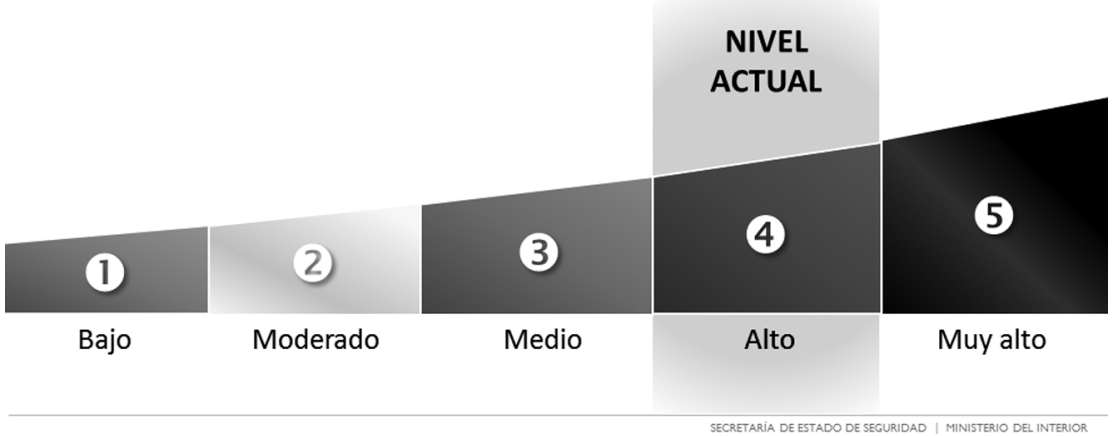

Source: Author's analysis on the basis of data from Ministry of the Interior of Spain.

*1. Low, 2. Moderate, 3. Medium, 4. High (current level), 5. Very High.

It would be possible to determine the existence of an endogenous and an exogenous threat, in spite of globalization present in all areas (economy, politics, society or technology), including the globalization of evil.

With respect to the endogenous threat, it reveals the existence of networks, cells and radical individuals established in Spain. In fact, even though their objective is still essentially logistic, especially in what refers to sending combatants to conflict zones, we cannot dismiss the fact that any of these structures could revert their activity, so that they decide to commit terrorist attacks in Spain, either by their own means and motivations, or induced by international organizations, as recent attacks in France have confirmed. This situation could also be favored by the return of jihadists coming from conflict zones, who could at any moment invigorate actions on the national territory with their new ideological and operative capacities obtained in their displacement. We cannot dismiss either the action of individual terrorist actors ("lone wolves"), given the increasing effectiveness of the extremist propaganda and the existence of radicalization centers in our country. Likewise, we would include the risk that derives from the frustrated individuals when they try to move to Syria and Iraq, as well as released prisoners after serving out their sentences.

The exogenous threat is the one that comes from international terrorist organizations and that could manifest through oriented or coordinated attacks from outside, or against Spanish interests abroad, with motivations linked to the factors that have been previously mentioned (historical aspects, anti-terrorist activity or participation in international missions of Spain). The threat is focused on Daesh, not forgetting the continuity of Al Qaeda either, especially 
through its franchise Al Qaeda at Islamic Maghreb, which is active in calling for getting back Al Andalus.

In this case, as we have previously pointed out, the proximity of conflicts in the Sahel and the Maghreb, with states in a situation of huge fragility (Mali), failed states (Libya) or states subjected to an important terrorist action (Tunisia). These environments foster the existence of several radical groups, the free movement of firearms and the use of organized crime networks for their financing. They become logistics, recruitment, and training, as well as dissemination centers of jihadists to other parts of the world. Considering the possible return of Jihadists from conflict zones, the countries of North Africa present data to be considered (Morocco, Algeria, Tunisia). The dismantled networks in Spain have shown the existing connection with Morocco, which has increased its alert level.

\section{Efforts against Jihadism in Spain}

Spain is facing the current threat with a holistic vision and an integrated action. In this sense, the year 2015 has been especially important, with measures from different spheres, making use of all the resources available in the rule of law. When facing an asymmetrical threat (no norms, no values, with plenty of resources, opaque and diffuse, resilient and adaptive), the rule of law must have the necessary tools to provide measures that can ensure the safety of the citizens and that allows the citizens to exercise their full rights and freedoms. The great challenge, as in the rest of European countries, is to achieve security, that will never be absolute, which entails the least degree of intrusion into citizens' rights and liberties, provided with the necessary guarantees, and which do not involve a change in our way of living. The current risk is to place freedom at the service of security.

\subsection{Characteristics of the fight against terrorism in Spain}

In a review of Frank Foley's work, Countering Terrorism in Britain and France: Institutions, Norms and the Shadow of the Past,${ }^{17}$ Blanco and Cohen, ${ }^{18}$ after a bibliographical revision, make groups of the criteria that can characterize the fight against terrorism of a state:

17 F. Foley, Countering Terrorism in Britain and France. Institutions, Norms and the Shadow of the Past, University Printing House, Cambridge 2013.

18 J. M. Blanco, J. Cohen, Reseña obra de Frank Foley, "Cuadernos de la Guardia Civil" no. 5, 2015, available at http://bibliotecasgc.bage.es/cgi-bin/koha/opac-detail. pl?biblionumber=16976, accessed 20 December 2015. 
Figure 8: Counter-terrorism factors in Spain

\begin{tabular}{|c|c|}
\hline Factors & Spain \\
\hline $\begin{array}{l}\text { Historical, geographical } \\
\text { and demographical } \\
\text { aspects }\end{array}$ & $\begin{array}{l}\text { It makes reference to the structural issues previously } \\
\text { mentioned }\end{array}$ \\
\hline Priorities & $\begin{array}{l}\text { The fight against Daesh and violent radicalization are the two } \\
\text { political priorities in terms of security and one of the biggest } \\
\text { challenges to National Security. }\end{array}$ \\
\hline $\begin{array}{l}\text { Nature and intensity of } \\
\text { the threat }\end{array}$ & $\begin{array}{l}\text { The threat is Spain in obvious and is materialized in the } \\
\text { different intentions from groups or individuals. The intensity } \\
\text { of it varies over time. }\end{array}$ \\
\hline $\begin{array}{l}\text { Impact of previous } \\
\text { events and experiences } \\
\text { against terrorism }\end{array}$ & $\begin{array}{l}\text { The attacks of May } 11^{\text {th }}, 2004 \text { had great impact and represented } \\
\text { an inflexion point. The impact was massive in terms of lives } \\
\text { and social and political polarization. The fight against the } \\
\text { terrorist group ETA has been an important experience in the } \\
\text { fight against this scourge through the intense use of the tools } \\
\text { that the rule of law provides. }\end{array}$ \\
\hline State capacity & $\begin{array}{l}\text { Spain shows a clear internal capacity to fight against terrorism, } \\
\text { but not at the international (compared with US or France). }\end{array}$ \\
\hline Existing values & $\begin{array}{l}\text { As a European model, we do have guarantees to protect the } \\
\text { rights and freedoms of the citizens. Spain could represent a } \\
\text { mixed model in comparison to the French one (security above } \\
\text { all) and the British one (rights and freedoms as the priority). }\end{array}$ \\
\hline Institutions & $\begin{array}{l}\text { In Spain, we have also experienced the international trend } \\
\text { toward greater coordination of intelligence services and } \\
\text { security forces. }\end{array}$ \\
\hline $\begin{array}{l}\text { Other facts: caricatures } \\
\text { of Mahomet, veil, etc. }\end{array}$ & Low-middle level of damage perception. \\
\hline $\begin{array}{l}\text { Legal system of the } \\
\text { State }\end{array}$ & $\begin{array}{l}\text { It is related to the judicial model. In France, the magistrates } \\
\text { are the ones who guide the investigations. In the UK, the } \\
\text { separation of powers and judicial independence represent a } \\
\text { key principle. }\end{array}$ \\
\hline $\begin{array}{l}\text { Impact of counter- } \\
\text { terrorism actions }\end{array}$ & $\begin{array}{l}\text { The former and current measures form an antiterrorist model } \\
\text { over time and can have both a positive and a negative impact } \\
\text { (stigmatization of communities, increase of xenophobia and } \\
\text { hate crimes, vigilantism or control of ideologies and speech). }\end{array}$ \\
\hline Other relevant criteria & $\begin{array}{l}\text { This makes reference to the relevant factors already mentioned: } \\
\text { opportunity criteria, international agreements, security alert } \\
\text { and social alarm, party policies, social support... }\end{array}$ \\
\hline
\end{tabular}

Source: J. M. Blanco, J. Cohen, The future of counter-terrorism in Europe. The need to be lost in the correct direction, "European Journal of Future Research" vol. 2, no. 1, 2014. 
On the basis of these approaches, we can conclude that Spain has an intense counter-terrorism system.

\subsection{The fight against terrorism in $\mathbf{2 0 1 5}$}

After the generalized psychosis in Europe, especially after the attacks in January and on November $13^{\text {th }}, 2015$ in Paris and other global actions of Daesh, Spain has reacted by developing two basic principles: unity and firmness.

In February 2015, the party in power (Popular Party, PP) and the biggest opposition party (Spanish Socialist Party, PSOE) signed an agreement in order to adopt counter-terrorism measures, showing that certain national policies should be above the governments of each period. PP, PSOE, CC, UPN and Foro Asturias in the first place, and Ciudadanos, UPyD, Unió and el PAR, have signed it 9 months later. The pact is based on eight basic points, and it is especially relevant because it represents the political unity in the face of the threats. On the document, all the signers agree to modify the Criminal Code in relation to terrorism; to apply the maximal penalty of imprisonment for terrorist crimes related to deaths; the promotion of legislative measures that improve the framework for action for judges, attorneys and law enforcement agencies; to keep alive the memory of victims; to provide the means and resources for the fight against terrorism; to activate policies against violent radicalization that includes racism, xenophobia and discrimination; to boost Spain's participation in the European Union and international institutions and promote initiatives in the Parliament that seek to achieve the greater consensus.

At the normative level, several important measures have been adopted. For example, those included in the Organic Law 2/2015, from March $30^{\text {th }}$ that has modified the Criminal Code and introduced a new crime and penalty classification, with the aim of adapting it to the evolution of the jihadist movement. In such way, it has recognized the role of the fighters returning to Spain and the individual terrorists (or most commonly known as "lone wolves"). The Organic Law 13/2015, from October $5^{\text {th }}$, modifies the Criminal Procedure Court, which facilitates the interception of communication through new technologies, the introduction of trojans for investigative purposes, and the use of secret informatics agents, always with a judicial authorization.

A Strategic National Plan against Violent radicalization was published in 2015. Different actors participate in the fight against terrorism and this can be shown in the plan: Muslim communities, the Spanish Federation of Municipalities and Provinces, law enforcement agencies, etc. The process must include private security sector, Academia, citizens and the mass media. It implies the development 
of a culture of security. As we have already mentioned, Spain is developing a continuous policing and judicial activity when fighting against jihadist terrorism.

At the beginning of December 2015, the Ministry of the Interior opened a service for citizen complaint against possible radicalization situations that works through a web page, a telephone number, an email or an app (AlertCops), and that is a part of the plan called Stop Radicalisms. Sources from the Ministry of the Interior informed that in less than one month (from December $4^{\text {th }}$ to December $30^{\text {th }}$ ), they received almost 600 alerts from the citizens, 270 out of which were really relevant in the fight against terrorism. The aim of this plan (that ensures anonymity of the complainer) is to give a voice to the alerts in cases of radicalization in schools or neighborhood, or the disappearance of people suspected to have travelled to Syria or Iraq to join Daesh.

Besides, at the end of 2015, the Ministry of the Interior has started to spread videos that counteract the jihadist propaganda of Daesh. These videos are published in the Internet and social media with the hashtag \#DaeshVidasRotas, which means "Daesh broken lives." The videos are in Spanish and in Arabic and are produced by the Sawab Centre, an initiative from the USA and the United Arab Emirates. However, there is a plan to self-elaborate videos from the Intelligence Centre against Terrorism and Organized Crime (Centro de Inteligencia contra el Terrorismo y el Crimen Organizado, CITCO).

At the international level, Spanish activity is also remarkable. Spain is an active partner with the United States in efforts to track and disrupt transnational terrorism. Spain deepened its cooperation with Morocco, Algeria, Mali, and Mauritania to combat and contain the threat posed by Al Qaeda (AQ), its affiliates, and likeminded groups.

Spain has been an active member and an outspoken supporter of the Global Coalition to Counter the Islamic State in Iraq and the Levant (ISIL) since its inception. Spain is an active member of the Global Counterterrorism Forum.

Spain is a member of the Financial Action Task Force (FATF) and the Egmont Group, a global association of financial intelligence units. Spain was reviewed under the new round of FATF evaluations and found to have "a strong system to combat money laundering and terrorist financing, with up-to-date laws and regulations and sound institutions for combating these threats." The evaluation also recommended improvements "such as the implementation of targeted financial sanctions to allow the freezing of terrorism-related assets."

Since 2004, Spain has been part of the informal working group on Jihadist known as the $5+5$. The group brings together defense ministers or their designees from five European countries (Spain, Portugal, France, Italy, and Malta) and 
five Maghreb countries (Mauritania, Morocco, Algeria, Tunisia, and Libya). Its mission is to exchange information and discuss the operational implications of the threat from violent Islamist extremists in the European theater, including the threat posed by returning foreign terrorist fighters.

Spain's participation in the G-4 with Portugal, France, and Morocco also has an operational objective. The four countries freely exchange tactics and intelligence on counternarcotics, counterterrorism, and organized crime/illegal immigration. Spain continued its work with the Global Initiative to Combat Nuclear Terrorism.

Despite all this, the path of the fight against terrorism will be long and painful. This effort would require not only to implement more measures but also to achieve equilibrium between privacy and rights and freedoms.

Therefore, there are still some remaining challenges that should be added to those that will come from the evolution of terrorism: increase in social participation, progress of the culture of security, fight against radicalization in schools, attention to hate crimes, engagement of the media in the fight against terrorism, implementation of national plants with local police and members of the private security sector (as the first action forces in attacks against soft targets), strengthening of coordination levels, existence of clear police action protocols at all levels, promotion of knowledge and intelligence in such a complex environment, collaboration with a greater number of actors and stakeholders, introduction of measures to evaluate the fight against terrorism (evidence based policing), and improvement of the police resources, among others.

\section{The Efforts of the Guardia Civil against Jihadism}

A summer course celebrated in July 2015, in collaboration with the University Institute of Research in Homeland Security (IUISI) and Universidad de la Rioja, presented different levels of action of the Civil Guard against jihadism.

Currently, the Brigadier leads the Information Department, with the mission of fighting terrorism. There is a second authority, the Colonel; the technical area also managed by a Colonel and 5 Central Units, managed by the Lieutenant Colonels. The Special Central Unit number 1 (UCE-1), is focused on internal national terrorism; the Special Central Unit number 2 (UCE-2) is focused on international terrorism; the Special Central Unit number 3 (UCE-3) is in charge of general information, labor and social issues, and counterintelligence. There is a Central Unit for Logistic Support (UCAL) and the Operational Support Group.

The UCE-2, within its area of responsibility in fight against global terrorism, is the Unit directly in charge of the counter-terrorism activity in the frame of Islamist terrorism. For that purpose, it has two groups, one for obtaining (managing 
sources of information) and one for elaborating (analysis). It has also an economic investigation section that is focused on the research concerning everything related to the financing of terrorism. In almost forty operations of the Unit, nearly 150 people have been arrested since 2004 .

The Information Department acts both at the strategic and operative levels, participating in all decision-making organs of the Ministry of the Interior, and in collaboration with the Intelligence Center against Terrorism and Organized Crime (CITCO). The Information Department covers all intelligence analysis and investigation areas against the terrorist and violent radicalization phenomena, such as groups and individuals, activities, propaganda, communication in social media or financing.

CITCO is the result of the union, in 2014, of the former National Centre for Antiterrorist Coordination (CNCA) and the Intelligence Centre against Organized Crime, created after the attacks of March $11^{\text {th }}, 2004$. The Intelligence Centre against Terrorism and Organized Crime (CITCO) has an organic level of general sub-directorate and is in charge of the reception, integration and analysis of the strategic information available in the fight against any kind of organized crime, terrorism and violent radicalization, the design of specific strategies against these threats, as well as - if needed - the creation of action and operative coordination criteria of the acting bodies in cases of coincidence or concurrence in the investigations.

This growing link between criminal and terrorist activity, already known but proved with the recent Paris attacks and the flow of weapons in the EU, makes necessary the implication of other units of the Civil Guard, from their different fields of activity. The action of a criminal group can lead to the dismantling of a terrorist cell. In this sense, it must be remarked how the Civil Guard, through the Judicial Police Department, fights all types of organized crime.

Moreover, the international dimension of the Civil Guard is another factor to point out when fighting terrorism. The global world in which we live points out the importance of the external action of the state. This external action is reflected mainly in three areas: cooperation with other police forces and international organizations, support the actions of the Ministry of Foreign Affairs and Cooperation (MAEC), and participation in crisis management operations.

The Civil Guard has some features and capabilities that make it perfect to take on these responsibilities. The Civil Guard is an ideal tool to be deployed outside our borders in support of missions for crisis management, both military and civilian, improving post-conflict stabilization processes, in which the Civil Guard can play a key role due to their police and military capacities. 
This presence is reflected in the ongoing participation of members of Civil Guard in international organizations, where decisions are taken at the European level and within the United Nations, and where initiatives or strategies are designed in the field of security. It is also common to find civil guards cooperating closely with other police forces in operations against terrorism, illegal immigration and organized crime.

Within the Ministry of Foreign Affairs and Cooperation, the Civil Guard supports the governmental action to strengthen the security of embassies in high-risk countries. Civil Guard has aggregates and counselors in several embassies, supporting the external action, while facilitating police cooperation.

Finally - and with the aim of exploiting the different open sources of information, the relations with universities and think tanks, the participation in research projects of the EU and the elaboration of future studies about the criminal phenomenon - the Guardia Civil has a Centre of Analysis and Foresight.

According to the US Department of State, "the National Police and the Civil Guard share responsibility for counterterrorism and cooperate well with the United States, with strong information sharing and joint threat assessments." ${ }^{19}$

The European Commission decided to establish a new European Counter Terrorism Centre (ECTC), launched on January 2016. Mr. Manuel Navarrete Paniagua, a high-ranking officer of the Spanish Civil Guard with extensive practical counter terrorism experience, will lead it. He was already the head of the counter terrorism unit at Europol. Currently, 39 staff members and 5 seconded national experts work in the ECTC. Working alongside other operational centers at Europol, such as the European Cyber Crime Centre (EC3), the ECTC will be a constituent part of Europol, under the general command of its Director, and will serve to augment the organization's capabilities as the EU's law enforcement agency. It is an evidence of the experience and good work done by the Civil Guard against terrorism.

\section{Conclusion}

After the Paris attacks, Spain has been able to show firmness and unity. No event has been cancelled and the lives of the citizens have not suffered any changes. In a calmness framework, different measures have been adopted and the level of terrorist alert has been maintained (or only "reinforced", according to the Minister of the Interior). At the same time, measures have been adopted in every sphere as a way of adaptation to this new phenomenon, that is not new, but that evolves

19 US Government, Country Report on Terrorism 2014, available at http://www.state.gov/j/ ct/rls/crt/2014/index.htm, accessed 20 January 2016. 
and adapts to a complex and changing environment at the political, social and technological levels, in an asymmetrical confrontation.

Firmness and unity are the pillars for the counter-terrorism action. Before that action, we need to have the best knowledge and intelligence that allow a better analysis to support the decision-making process. This process must include longterm views, so that, step by step, the counter-terrorism activity will stop being so reactive and will become much more preventive and anticipatory.

The road will be long. More attacks will occur. It requires an exercise in creativity and imagination to exploit all the tools that are allowed by the rule of law, bearing in mind that the role of a law enforcement agency is, first of all, to guarantee the exercise of the rights and freedoms of citizens.

\section{References}

J. M. Blanco, J. Cohen, The future of counter-terrorism in Europe. The need to be lost in the correct direction, "European Journal of Future Research", no. 1 (2), 2014, available at http://link.springer.com/article/10.1007\%2Fs40309-014-0050-9, accessed 20 December 2015.

J. M. Blanco, J. Cohen, Reseña obra de Frank Foley, "Cuadernos de la Guardia Civil", no. 5, 2015, available at http://bibliotecasgc.bage.es/cgi-bin/koha/opac-detail.pl?biblionumber $=16976$, accessed 20 December 2015.

J. M. Blanco, J. Cohen, Entornos urbanos frágiles, Diario BEZ 2015, available at http://www.bez.es/617991634/Tras-los-atentados-de-Paris-III.-Entornos-urbanos-fragiles.html, accessed 20 December 2015.

C. T. Call, Beyond the failed state: Toward conceptual alternatives, "European Journal of International Relations" 2010, US Institute for Peace, Washington 2010.

J. Cohen, J.M. Blanco, El crimen organizado y la estabilidad estatal en México, I Congreso de Estudios Militares, Granada 2014, available at http://estudiosmilitares.es/comunicaciones/J\%C3\%A9ssica\%20Cohen\%20Villaverde\%20 y\%20Jos\%C3\%A9\%20M\%C2\%AA\%20Blanco\%20Navarro.pdf, accessed 20 December 2015.

L. de la Corte, ¿Enclaves yihadistas? Un estudio sobre la presencia y el riesgo extremistas en Ceuta y Melilla, "Revista de Estudios en Seguridad Internacional", no. 2(1), 2015, pp. 1-34, available at http://www.seguridadinternacional.es/rev ista/?q=content/\%C2\%BFenclaves-yihadistas-un-estudio-sobre-la-presenciay-el-riesgo-extremistas-en-ceuta-y, accessed 20 December 2015.

L. de la Corte, Actividad yihadista en Ceuta: antecedentes y vulnerabilidades, Real Instituto Elcano 2015, available at http://www.realinstitutoelcano.org/ documentos/DT2007/DT28-2007_de_la_Corte_actividades_yihadistas_ Ceuta.pdf, accessed 20 December 2015. 
F. Foley, Countering Terrorism in Britain and France. Institutions, Norms and the Shadow of the Past, University Printing House, Cambridge 2013.

J. Jordan, The evolution of the structure of jihadist terrorism in Western Europe: the case of Spain, "Studies in Conflict and Terrorism" no. 37 (8), 2015.

Observatorio Andalusí, Estudio demográfico de la población musulmana, 2015, available at http://observatorio.hispanomuslim.es/estademograf.pdf, accessed 20 January 2016.

Pew Research Center, Faith in European Project Reviving, 2015, available at http:// www.pewglobal.org/files/2015/06/Pew-Research-Center-European-UnionReport-FINAL-June-2-20151.pdf, accessed 20 December 2015.

F. Reinares, ¿Por qué el terrorismo yihadista afectará más a unos países europeos que

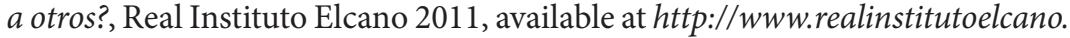
org/wps/portal/rielcano/contenido?WCM_GLOBAL_CONTEXT=/elcano/ elcano_es/zonas_es/ari82-2011, accessed 20 December 2015.

F. Reinares, C. García-Calvo, Terroristas, redes y organizaciones: facetas de la actual movilización yihadista en España, Real Instituto Elcano 2015, available at http:// www.realinstitutoelcano.org/wps/portal/web/rielcano_es/contenido? $\overline{W C M}$

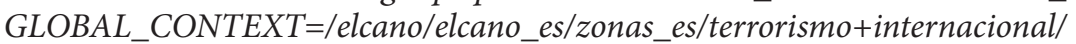
dt17-2015-reinares-garciacalvo-terroristas-redes-organizaciones-facetas-actualmovilizacion-yihadista-espana, accessed 20 December 2015.

Spanish Government, Antiterrorism Agreement, available at http://www.lamoncloa. gob.es/espana/eh15/seguridad/Documents/Acuerdo\%20para\%20afianzar\%20 la\%20unidad\%20en\%20defensa\%20de\%20las\%20libertades\%20y\%20en\%20 la\%20lucha\%20contra\%20el\%20terrorismo\%202015.pdf, accessed 20 January 2016.

Spanish Government, Hate crimes in Spain 2014, available at http://www.interior. gob.es/documents/10180/1643559/Estudio+Incidentes+Delitos+de+Od io+2014.pdf/70073437-795d-4ce1-acfc-ed92b02cf1a6, accessed 20 January 2016.

Spanish Government, Operations developed and people arrested, available at http:// www.interior.gob.es/documents/10180/1210364/TABLA+DETENIDOS+TE RRORISMO+INTERNACIONAL+\%2814-12-2015\%29.pdf/026336fc-f9c74e7f-9c71-28750538310e, accessed 20 January 2016.

Spanish Government, Stop Radicalisms, available at https://stop-radicalismos.ses. mir.es/, accessed 20 January 2016.

Spanish Government, Strategic National Plan Against Violent Radicalisation, available at http://www.lamoncloa.gob.es/consejodeministros/referencias/ documents/2015/refc20150130e_1.pdf, accessed 20 January 2016. 
The Soufan Group, Foreign Fighters. An Updated Assessment of the Flow of Foreign Fighters into Syria and Iraq, 2015, available at http://soufangroup. com/wp-content/uploads/2015/12/TSG_ForeignFightersUpdate3.pdf, accessed 20 January 2016.

J. P. Sullivan, Narco-Cities: Mexico and Beyond, "Small Wars Journal" 2014, available at www.smallwarsjournal.com, accessed 20 January 2016.

M. Torres, Referencias a España en la propaganda yihadista, 2015, available at http:// www.seguridadinternacional.es/?q=es/content/referencias-espa\%C3\%B $\overline{1-e n-}$ la-propaganda-yihadista\# overlay-context=es/content/operaciones-policialescontra-el-terrorismo-yihadista-en-espa\%25C3\%25B1\%3Fq\%3Des/content/ operaciones-policiales-contra-el-terrorismo-yihadista-en-espa\%25C3\%25B1, accessed 20 January 2016.

M. Torres, La lucha por liderar el yihadismo magrebí aumenta la amenaza sobre España, Observatorio Internacional de Estudios sobre Terrorismo (OIET), 2015, available at http://observatorioterrorismo.com/terrorismo-internacional/ la-lucha-por-liderar-el-yihadismo-magrebi-aumenta-la-amenaza-sobreespana/d, accessed 20 January 2016

US Government, Country Report on Terrorism 2014, available at http://www.state. gov/j/ct/rls/crt/2014/index.htm, accessed 20 January 2016. 


\section{Damian Szlachter and Piotr Potejko ${ }^{1}$}

\section{Religious Extremism among Islam Believers Living in Poland - the Results and Conclusions of the Research}

\section{Introduction ${ }^{2}$}

Radicalization is a process in which individuals adopt an extremist system of values, which accepts and supports the use of violence and intimidation. The objective of such attitude is to exert strong influence on society, achieve far-reaching changes, and even urge the followers to similar acts. The most extreme stage of radicalization is reached when terrorist activities are undertaken by a given individual or group.

An important tool of counteracting the phenomenon in dispute in its all stages, including terrorist activity, is a full recognition of the sources of extremism threats and identification of the most extremist environments - economic, psychological, social, political as well as religious factors that foster the development of radicalization of opinions. The way individuals perceive themselves and the environment in which they exist together with the specificity of their beliefs related to extremism, are crucial. The threat of radicalization is not only the probability of violence or the risk of its use, but also the possible driving force of other forms of detrimental impact on society.

In 2011, in Poland the pioneer research program titled "Recognition, counteraction and prevention of the phenomenon of radicalization of religious opinions

1 The team members of a research project titled: "Recognition, counteraction and prevention of the phenomenon of radicalization of religious opinions among Islam believers living in the Republic of Poland - as an element of national system of early detection of terrorist threats" conducted in the framework of the research program of the Police Academy in Szczytno titled: "Counteracting and combatting organized crime and terrorism in conditions of safe, accelerated and sustainable socio-economic development" No. O R00 0040 07).

2 The research was realised in cooperation with the team of the Institute of Psychology at the Polish Academy of Science (pl. IP PAN), composed of: Urszula Jakubowska (manager), Janusz Reykowski (consultant), Piotr Radkiewicz, Paweł Boski, Krzysztof Korzeniowski, Bogdan Wojciszke. The project was realized in the framework of the aforementioned grant no. OR00004007 from the Ministry of Science and Higher Education during 2009-2011. 
among Islam believers living in the Republic of Poland..." was conducted. The purpose of this project was to measure and assess the scale of radicalization and identify the groups exhibiting relatively strongest extremist attitudes. The researchers also aimed at indicating psychological factors that foster the development of the discussed phenomenon. The key results of the aforementioned research are presented below.

\section{Theoretical Presumptions of the Research}

For the purpose of the research, it has been presumed that religious extremism means the co-occurrence of two interrelated categories of attitudes: religious fundamentalism and agreement on employing violent actions in order to solve religious and socio-political conflicts. ${ }^{3}$ The first category, fundamentalism, was analyzed in individual (psychological) terms as a specific type of religious beliefs, irrespective of particular denomination, constituting an evidence of fundamentalist attitudes. According to the theory devised by Altemeyer and Hunsberger, ${ }^{4}$ religious ethnocentrism, expressed in the conviction that one's own religion is the only truth about the world and meticulous observance of its rules constitute the condition of salvation. ${ }^{5}$ In terms of the second category (the approval of using force in solving socio-political conflicts), violent behaviors are treated as a criterion feature for the definition of political extremisms, ${ }^{6}$ including religious terrorism ${ }^{7}$ and secular terrorism. ${ }^{8}$

In the research, it has been assumed that co-occurrence of these two categories is evidential for psychological maturity for engaging in a particular situation into radical political actions of religious background. In other words, individuals who

3 U. Jakubowska, J. Reykowski, P. Radkiewicz, P. Boski, K. Korzeniowski, B. Wojciszke, Ekstremizm religijny wśród wyznawców islamu mieszkających $w$ Polsce. Raport z badań(typescript).

4 B. Altemeyer, B. Hunsberger, Authoritarianism, religious fundamentalism, quest, and prejudice, "The International Journal for the Psychology of Religion", no. 2, 1992, pp. 113-133; B. Altemeyer, B. Hunsberger, Fundamentalism and authoritarianism, in: Handbook of the Psychology of Religion and Spirituality R.F. Palotzian, C.L. Park (eds.), Guilford Press, New York 2005, pp. 378-393.

5 Ibid.

6 U. Jakubowska, J. Reykowski, P. Radkiewicz, P. Boski, K. Korzeniowski, B. Wojciszke, Ekstremizm religijny...

7 B. Bolechow, Terroryzm, Wydawnictwo PWN, Warsaw 2010.

8 J. Horgan, Psychologia terroryzmu, Wydawnictwo PWN, Warsaw 2008; D. Szlachter, Walka z terroryzmem $w$ Unii Europejskiej - nowy impuls, Wydawnictwo Adam Marszałek, Toruń 2007. 
show high level of both religious fundamentalism and approval of violence in solving socio-political conflicts may quite rapidly and easily undertake radical actions if they are inspired by external factors such as: strong leader, conflict, a lack of ability to fulfill their essential needs.

What is common for various isolated opinions is the belief that the world is unkind, aggressive and threatening. Scientific knowledge ${ }^{9}$ and the results of the research on religious fundamentalism indicate that experience of the world in categories of menace stems from the feeling of fear, harm, frustration and threat. ${ }^{10}$ Such attitude leads to the need of complete submission to an authority figure. ${ }^{11}$ It as well may be a political or religious leader, as an idea or notion. ${ }^{12}$

To reach the valid conclusions it is vital to find out what factors make some people become religious extremists. It has been presumed that individual differences in the level of religious extremism may stem from the configuration of specific believes about ourselves and the social world. ${ }^{13}$ For that purpose, the following variables have been measured in the research: authoritarian personality, social trust, legitimization of social order, social cynicism, political cynicism, the feeling of collective harm, the number and quality of contacts with people and the assessment of the quality of one's life.

\section{Methodology used in the Research}

\section{Examined individuals}

In the research, a group of 536 people ( 295 women and 241 men) was examined. ${ }^{14}$ They were purposefully selected according to the criteria of their denomination,

9 A.T. Beck, Prisoners of hate. The cognitive basis of anger, hostility, and violence, Harper Collins Publishers, New York 1999.

10 J. W. Jones, Why does religion turn violent? A psychoanalytic exploration of religious terrorism, "Psychoanalitic Review" no. 93, 2006, pp. 167-190; U. Jakubowska, W. Oniszczenko, Genetyczne i psychospołeczne uwarunkowania postawy fundamentalistycznej religijnie, in: Przekonania $w$ życiu jednostek, grup, społeczności A. Cisłak, K. Henne, K. Skarżyńska (eds.), Academica Wydawnictwo SWPS, Warsaw 2009, pp. 31-48.

11 B. Altemeyer, B. Hunsberger, Authoritarianism, religious...op.cit.;

12 Orthodox system of religious beliefs e.g. see: B. Altemeyer, The Authoritarian...op.cit.

13 U. Jakubowska, J. Reykowski, P. Radkiewicz, P. Boski, K. Korzeniowski, B. Wojciszke, Ekstremizm religijny ...op.cit.; U. Jakubowska, Ekstremizm polityczny, Gdańskie Wydawnictwo Pedagogiczne, Gdansk 2005.

14 The analysis of the results comprised data form 534 people; results of 2 people were rejected because their group affinity appeared to be inconsistent with religious beliefs (e.g. Tatar-Catholic). 
ethnic origin and sex. It was assumed that the compared groups should be relatively equivalent in terms of age, sex and education distribution. The sample consisted of the following subgroups: a) 121 Muslim Poles (including 113 people of Tatar origin) and 123 Poles of denomination other than Islam/agnostics; b) 83 Chechen Muslim people and 85 refugees living in Poland of denomination other than Islam/agnostics; c) 62 foreign Muslim students and 60 foreign students of denomination other than Islam/agnostics. Table 1 presents characteristics of all groups due to sex, education, age and denomination:

Table 1: Socio-demographic characteristics of the examined groups

\begin{tabular}{|l|rrrrrr|r|}
\hline \multicolumn{1}{|c|}{ SEX } & $\mathbf{1})$ & $\mathbf{( 2 )}$ & $\mathbf{( 3 )}$ & $\mathbf{( 4 )}$ & $\mathbf{( 5 )}$ & $\mathbf{( 6 )}$ & $\mathbf{N}$ \\
\hline Woman & 47 & 50 & 71 & 74 & 27 & 25 & 294 \\
Man & 36 & 35 & 50 & 49 & 35 & 35 & 240 \\
EDUCATION & & & & & & & \\
Primary & 18 & - & 5 & 5 & - & - & 28 \\
Vocational & 8 & 4 & 6 & 6 & - & - & 24 \\
Secondary general & 32 & 39 & 38 & 39 & 5 & 1 & 154 \\
Post-secondary & - & 11 & 9 & 14 & 2 & - & 36 \\
Higher incomplete & 2 & 13 & 14 & 8 & 47 & 52 & 136 \\
Higher & 15 & 17 & 49 & 51 & 8 & 7 & 147 \\
$\quad$ AGE & & & & & & & \\
16-25 & 13 & 6 & 18 & 21 & 54 & 49 & 161 \\
$>$ 25-35 & 32 & 46 & 21 & 24 & 7 & 10 & 140 \\
$>35-45$ & 23 & 28 & 23 & 15 & - & - & 89 \\
$>45-55$ & 12 & 3 & 17 & 21 & - & - & 53 \\
$>55-65$ & 2 & 2 & 14 & 17 & - & - & 35 \\
$>65$ years & 1 & - & 27 & 24 & - & - & 52 \\
DENOMINATION & & & & & & & \\
Christian & - & 69 & - & 112 & - & 33 & 214 \\
Islam & 83 & - & 121 & - & 62 & - & 266 \\
Other & - & 7 & - & - & - & 4 & 11 \\
No denomination & - & 9 & - & 11 & - & 23 & 43 \\
\hline$\quad$ (N) & 83 & 85 & 121 & 123 & 62 & 60 & 534 \\
\hline
\end{tabular}

Legend:
(1) Muslim refugees from Chechnya
(4) Polish non-Muslim
(2) Non-Muslim refugees
(5) Foreign Muslim students
(3) Polish Muslim
(6) Foreign non-Muslim students 


\section{Research conditions and materials}

The research was conducted from July to mid-October 2010. It was carried out in small groups and individually, with care concerning the anonymity of measurement. During the research, the examined people were asked to complete a complex questionnaire consisting of the instruction, particulars and measurement scales. In the instruction, there was an explanation of the goal of the research and the rules of participation. The specification included questions for sex, education level, age and denomination or lack of it. After completing the form, participants placed them inside a pile of other forms or they sent it back by post. The data was also gathered during the Muslim League congress, after the religious ceremonies, in a refugee centre and during individual meetings in the participants' houses.

\section{Measurement scales applied in the research together with the Cronbach's alpha coefficient of reliability:}

Religious extremism

- Religious fundamentalism. ${ }^{15} 12$ positions; a Cronbach = 0.91; examples: God has given humanity a complete, unfailing guide to happiness and salvation, which must be totally followed; No single book of religious teaching contains all the intrinsic, fundamental truths about life (-4 - I strongly disagree, 0 - I feel neutral, +4 - I strongly agree).

- Approval of religious violence (scale formed for the needs of the research). 4 positions; a Cronbach $=0.60$; example: People who die for the sake of the nation are heroes deserving admiration (1 - I strongly disagree, 4 - I strongly agree).

- Approval of political violence. ${ }^{16} 4$ positions; $\alpha$ Cronbach $=0.78$. The respondents answered the questions it is allowed to, when the intention is good, throw eggs at your political opponents and pour on them ill-smelling liquid, set bombs in various facilities, imprison or kill people (1 - I strongly disagree, 4 - I strongly agree).

15 See: B. Altemeyer, B. Hunsberger, A revised Religious Fundamentalism Scale: The short and sweet of it, "The International Journal for the Psychology of Religion", no. 14, 2004, pp. $47-54$.

16 U. Jakubowska, Ekstremizm polityczny...op.cit. 


\section{Perceiving oneself and the social world}

- The feeling of collective harm. The respondents expressed their opinions on conditions for the development of other denominations in Poland: Catholicism, Judaism, Protestantism, Islam and Orthodox Church ( 1 - best conditions; 10 worst conditions).

- Authoritarianism. ${ }^{17}$ By virtue of this variable it was possible to verify individual's disposition to uncritical submission to authorities. 6 positions; a Cronbach $=0.78$; example: Respect should be always paid to those who are in power (1 - I strongly disagree, 4 - I strongly agree).

- Social trust. ${ }^{18}$ The variable verified the conviction if people are good by nature and if they may be trusted. 8 positions; $a$ Cronbach $=0.72$; examples: $B y$ nature people are friendly and kind-hearted to one another; We may say that more good than evil is being done in the world (1 - I strongly disagree, 4 - I strongly agree).

- Political cynicism. ${ }^{19}$ The variable measured the lack of trust in social institutions and disrespect for ethical rules in public life. 6 positions; $\alpha$ Cronbach $=$ 0.60 ; the respondents had to select one of six pairs of statements that is in their opinion closest to the truth, e.g. (A) Governments' representatives usually say the truth vs. (B) We mustn't believe in majority of statements pronounced by government's representatives.

- Social cynicism. ${ }^{20}$ The respondents approved or not of the conviction that preserving humanist and pro-social values in life makes no sense. 4 positions; a Cronbach $=0.65$; examples: People of good (kind) heart are often persecuted by others; Engaging in social affairs may bring only trouble to an individual (1 - I strongly disagree, 4 - I strongly agree).

17 See: K. Korzeniowski, O wielowymiarowości autorytaryzmu, in: Demokracja w Polsce. Doświadczanie zmian U. Jakubowska, K. Skarżyńska (eds.), Academica Wydawnictwo SWPS, Warsaw 2005, pp. 114-123.

18 U. Jakubowska, W. Oniszczenko, Genetyczne i psychospołeczne...op.cit.

19 See: P.M. Sniderman, A question of loyalty, University of California Press, Berkeley 1981.

20 P. Boski, J. Więckowska, M. Biłas-Henne, Cynicism in Love and in Politics, in:, Psychological aspects of socialaxioms K. Leung, M. H. Bond (eds.), Springer Verlag, New York 2008, pp. 239-267. 
- Legitimization of political system. ${ }^{21}$ The respondents answered the question if the world is well organized and if it needs changes. 8 positions; a Cronbach $=0.70$; examples: Every person in Poland has a real chance to achieve financial success and happiness; Poland is organized in such a manner that the majority of people do not get what they deserve (conversely) (1 - I strongly disagree, 7 - I strongly agree).

- People-to-people contacts. ${ }^{22} 5$ positions; $\alpha$ Cronbach $=0.81$; respondents were asked for the accuracy of statements describing their relationships with other people, e.g. Relationship with my family/friends give me the feeling of peace and safety ( 1 - strongly inaccurate; 4 - strongly accurate).

- Satisfaction from the present life. ${ }^{23}$ The respondents assessed their own life quality in the scale from 1 (worst) to 10 (best).

Cronbach's alpha values (from 0.60 to 0.91 ) indicate that the scales of sociopolitical attitudes and beliefs applied in the research are characterized by at least satisfactory reliability of measurement.

\section{Results ${ }^{24}$}

\section{Links among religious extremism dimensions}

Compliant to theoretical assumptions of the project, high results in measurement scales signify the readiness of an individual to religious extremism. Religious fundamentalism and the approval of the use of both religious and political violence are the dimensions that shall be independent from one another (have at least small positive correlation or even lack of it). Their intense, positive interaction means the inclination to extremist behavior.

21 See: A.C. Kay, J.T. Jost, Complementary justice: Effects of "poor but happy" and "poor but honest" stereotype exemplars on system justification and implicit activation of the justice motive, "Journal of Personality and Social Psychology" no. 85, 2003, pp. 823-837.

22 See: K. Kaniasty, Klęska żywiołowa czy katastrofa społeczna? Psychospołeczne konsekwencje polskiej powodzi 1997 roku, Gdańskie Wydawnictwo Pedagogiczne, Gdansk 2003.

23 See: K. Korzeniowski, O wielowymiarowości ...op.cit.

24 Statistical calculations by Ph.D. Piotr Radkiewicz from the IP PAN. 
Figure 1: Relations between religious fundamentalism and approval of religious violence

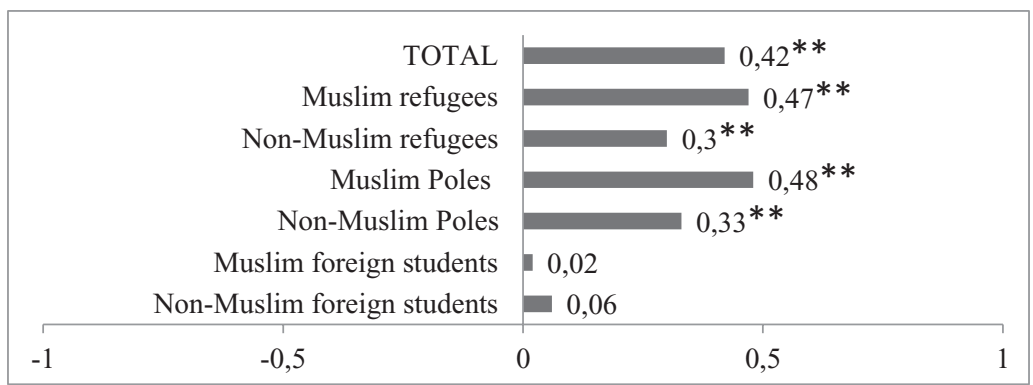

Pearson's r values

Legend (here and further): ${ }^{*} \mathrm{p}<=0.05 ; * * \mathrm{p}<=0.01$

The data in figure 1 was gathered from the whole sample and from the sample broken into groups. It indicates the correlation of religious fundamentalism with the agreement on applying violence in religious affairs. The value of the Pearson's $r$ coefficient amounts to $r=0.42$ for the whole sample and it is statistically significant $(\mathrm{p}<0.01)$. It shows that growing religious fundamentalism goes along with the increase in approval of religious violence. Statistically significant relations among those dimensions of extremism have been also observed in all groups of the examined participants, except for both Muslim and non-Muslim students. This may result from the specific nature of this group. Because of their age and education, students constitute the most homogeneous group, apparently unable to see the direct, functional relation between fundamentalist convictions of the superior role of religion in social life and violence resulting from the need to observe this ideology in everyday life. 
Figure 2: Relation between religious fundamentalism and approval of political violence Pearson's $r$ values

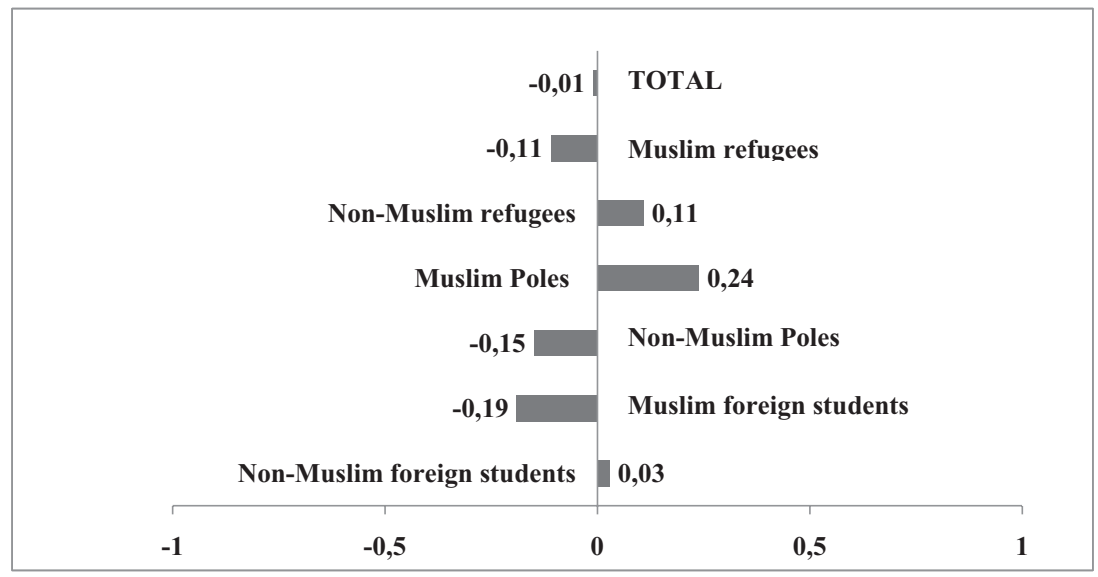

Pearson's r values

Correlation between religious fundamentalism and approval of political violence presented in Figure 2 is statistically insignificant in the whole sample $(r=-0.01$; $\mathrm{p}>0.05)$. The only group that this matter proves to be statistically significant are Muslim Poles $(r=0.24 ; \mathrm{p}<0.01)$.

Figure 3: Relation between the approval of both religious and political violence

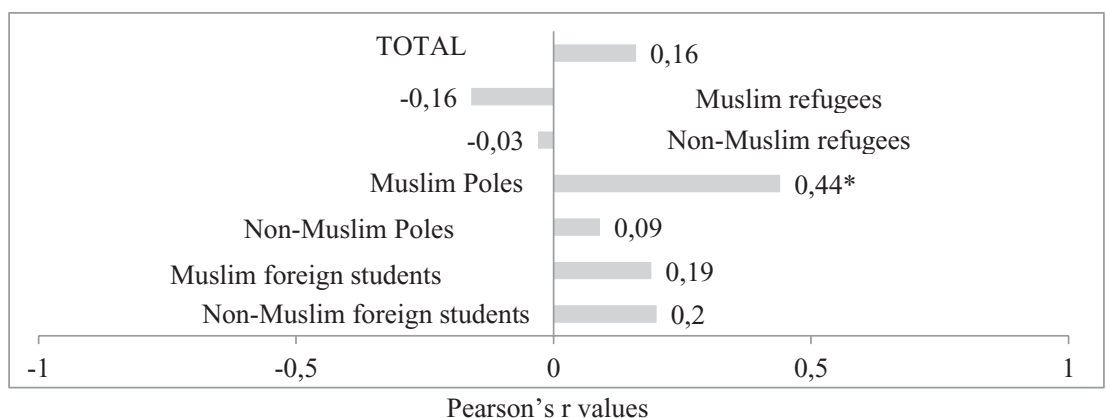

The results in Figure 3 show that the relation between approval of violence in both religious and political affairs is very poor. It amounts to $\mathrm{r}=0.16(\mathrm{p}<0.01)$ for the whole sample. In groups the statistically significant relation between these two variables can be noticed only among Muslim Poles ( $r=0.44 ; \mathrm{p}<0.01)$. 
The differences in the discussed relations among groups are worth pointing out. For students, for example, religious fundamentalism and approval of religious and political violence form a configuration in which these dimensions are completely independent. At the same time, however, in some communities all the listed dimensions may be strongly, positively correlated.

\section{Religious extremism in subgroups}

In the following stage of the results, pairs of subgroups were compared from the perspective of the variables defining religious extremism: religious fundamentalism, the approval of religious violence and the approval of political violence. The examination was carried out with the use of the Student's $t$-test for independent trials and the mean results for six groups are presented in figures 4,5 and 6 .

Figure 4: Religious fundamentalism - differences among groups

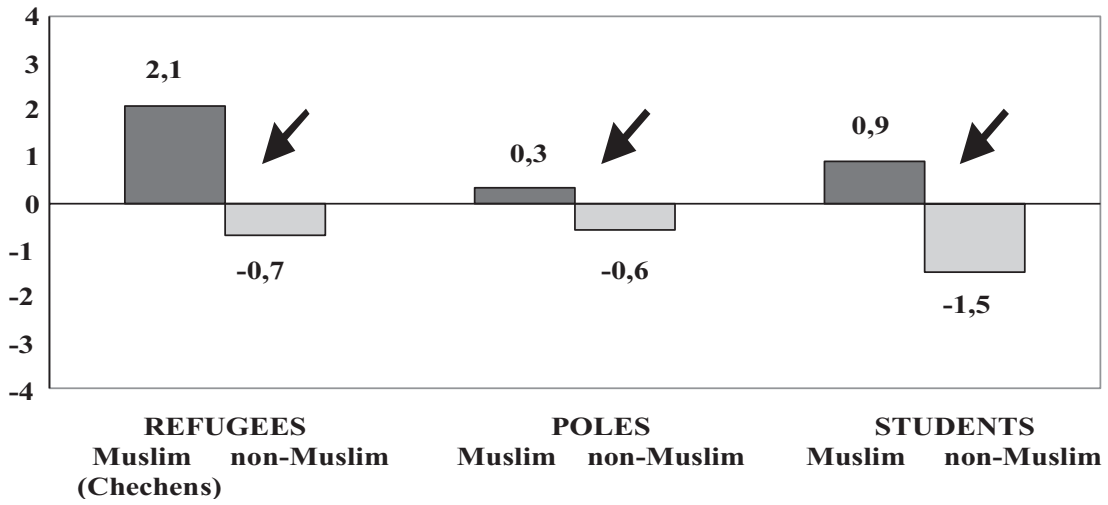

Explanation: Arrows indicate statistically significant differences among groups amounting to $\mathrm{p}<=0.05$.

Analyzing the outcome of comparison of all three pairs of groups, Islam followers achieve higher mean results on the scale of religious fundamentalism than their counterpart group consisting of non-Muslims (Figure 4). The highest level of fundamentalism is clearly seen among Chechen refugees - this group shows mean results not only higher than the mean for the non-Muslim refugees $(\mathrm{M}=2.1$ and $\mathrm{M}=-0.7 ; \mathrm{t}=12.6 ; \mathrm{p}<0.01$, respectively) but also the highest mean values of all other groups. What is worth noticing is the fact that there is a large 
difference (statistically significant $-\mathrm{M}=0.9$ and $\mathrm{M}=-1.5 ; \mathrm{t}=6.2 ; \mathrm{p}<0.01$, respectively) between Muslim and non-Muslim students. In the latter group, the lowest level of fundamentalism was noted. The difference between the group of Muslim Poles and its counterpart group of non-Muslim Poles is relatively smallest, but still statistically significant $(\mathrm{M}=0.3$ and $\mathrm{M}=-06 ; \mathrm{t}=4.4 ; \mathrm{p}<0.01$, respectively).

Figure 5: Approval of religious violence - differences among groups

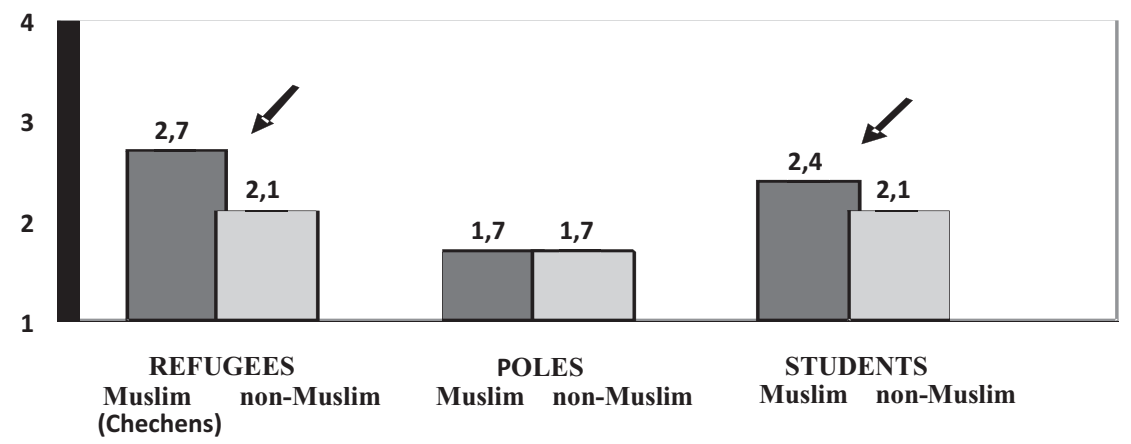

Explanation: Arrows indicate differences among groups which are statistically significant amounting to $\mathrm{p}<=0.05$.

According to data in Figure 5, Chechen refugees are most willing to accept religious violence. The mean value of the approval indicator in this group is not only higher than the mean results in its counterpart group of non-Muslim refugees $(\mathrm{M}=2.7$ and $\mathrm{M}=2.1 ; \mathrm{t}=7.6 ; \mathrm{p}<0.01$ respectively), but it is also higher than mean values in the other groups. The second position belongs to the students who are Islam followers - they show relatively high level of the examined variable.

There is not any statistically significant difference between Muslim and nonMuslim Poles - mean value of the approval of religious violence for both groups is on the same level which is the lowest one in the examined sample and amounts to $\mathrm{M}=1.7$.

Mean values presented in Figure 6 indicate that statistically significant differences in the level of political violence approval among groups do not appear. This result shows that in any of the examined samples no more than average level of approval of physical violence in political actions (including killing political opponents) has been noticed. 
Figure 6: Approval of political violence - differences among groups

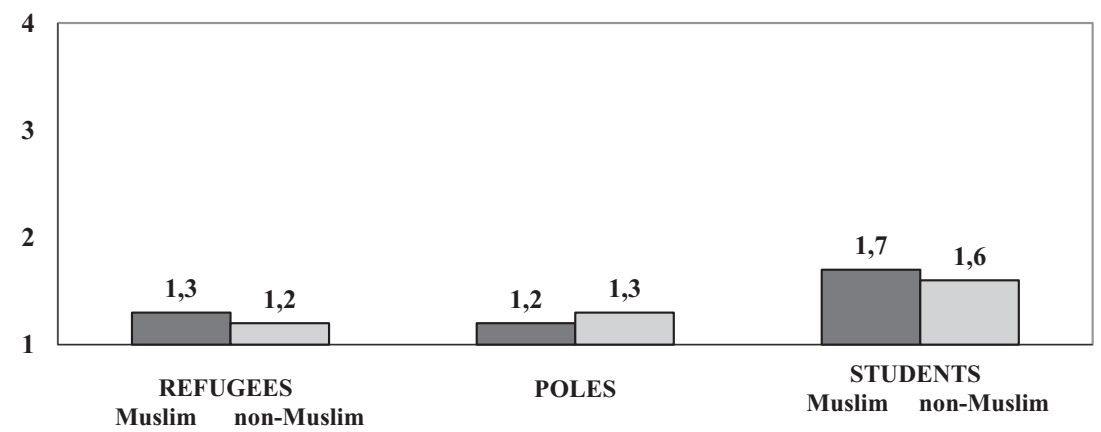

However, the result itself is quite significant. The variance of results in the scale of approval of this variable has been unusually small in the examined sample. $91 \%$ of respondents has not exceeded the mean value of 2 , which means lack of consent for violent acts. Only 16 respondents (3\% of the total) achieved the results showing relatively high approval (mean value of the result is equal to 3 and more) and further, thorough analyses, revealed that such people were randomly distributed in all the examined groups. Minor differences in the results may be linked to the impact of social approval of political violence on the respondent. The direct question whether we are able to kill, set bombs, etc. makes the respondents deny approval of such acts. However, the same question formulated in a vaguer form, for example as a request for opinion on suicidal or terrorist bombers, considerably changes the results.

Due to the very low differentiating power of the discussed variable, the approval of political violence was not taken into consideration in the construction of the general indicator of religious extremism. At the same time, however, because of quite high correlation of religious fundamentalism with the agreement on applying violence in religious affairs, it was adopted that the extremism indicator may be presented both in the form of continuous variable (indicator I), and categorical variable (indicator II).

\section{Religious extremism - indicator I}

The first indicator of religious extremism has been formed with the use of factor analysis. It is a statistical method which examines co-variances of variables controlled in the test, leading to determination of basic factors responsible for the occurrence of statistical relations (intercorrelations). By virtue of this method, it is possible to calculate numerical values of a superordinate factor (indicator I) and to write them in the form of so-called factor results (the distribution of the newly formed variable has the mean of 0 and standard deviation of 1). In this 
case the factor's results, signifying the extremism indicator, have been formed on the basis of correlation between religious fundamentalism and the approval of religious violence. Figure 7 presents differences among groups in the level of this indicator expressed in standard deviation units.

Figure 7: Religious extremism (indicator I) - differences among groups.

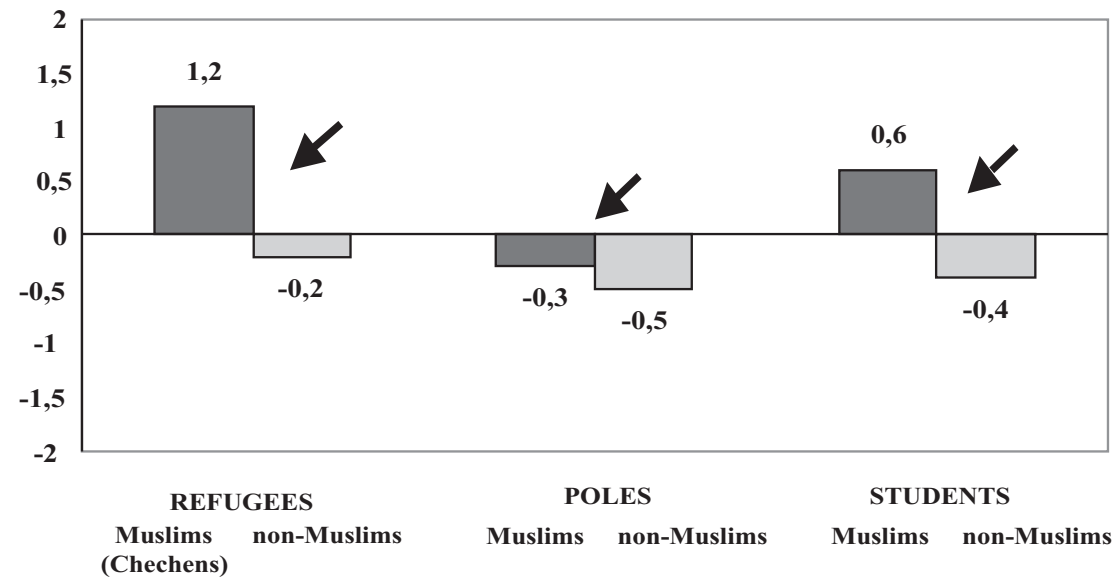

Explanation: Arrows indicate statistically significant differences among groups amounting to $\mathrm{p}<=0.05$

Figure 7 presents the data which confirms that the highest level of religious extremism has been noticed among the group of Chechen refugees. It is not only 1.5 of standard deviation higher than the mean in the group of non-Muslim refugees $(\mathrm{M}=1.2$ and $\mathrm{M}=-0.2 ; \mathrm{t}=11.8 ; \mathrm{p}<0.01$, respectively), but also much higher than the mean in the other groups (all the differences are statistically significant).

The tendency to extremist opinions is relatively high in the group of students who are Islam followers - it reaches value significantly higher both than the mean in the group of non-Muslim students $(\mathrm{M}=0.6$ and $\mathrm{M}=-0.4 ; \mathrm{t}=6.4 ; \mathrm{p}<0.01)$ and the mean in the rest of the groups except for Chechen refugees. A minor (although still statistically significant) difference has been observed among Poles - both Muslim and Catholic or aconfessional ( $\mathrm{M}=-0.3$ and $\mathrm{M}=-0.5 ; \mathrm{t}=2.2 ; \mathrm{p}<0.05$ respectively).

\section{Religious extremism - indicator II}

The second indicator of religious extremism is a category variable based on fourfield combination of religious fundamentalism and approval of religious violence. Distributions of both of those variables have been divided compliant to the value of the median into two categories - high and low intensity. Next they were crossed, 
resulting in the distribution of one four-category variable (compare Table 2). Summing up the number of four groups of respondents formed in this manner, the results in the total number $(\mathrm{N}=490)$ are lower than the initial number $(\mathrm{N}=534)$, as some of the participants refused to answer questions of one or the other scale (those respondents were excluded form analyses).

Table 2: Category indicator of religious extremism (indicator II)

\begin{tabular}{|c|l|cc|}
\hline \multicolumn{2}{|c|}{ N=488 } & \multicolumn{2}{c|}{ Approval of religious violence } \\
\cline { 3 - 4 } & LOW & LOW & HIGH \\
\hline \multirow{2}{*}{ Religious fundamentalism } & $172(35.2 \%)$ & $82(16.8 \%)$ \\
& HIGH & $97(19.9 \%)$ & $137(28.1 \%)$ \\
\hline
\end{tabular}

Two most distinguished groups formed with the use of this method are people who got low results in the fundamentalism and approval of religious violence scales $(\mathrm{N}=172-35.2 \%)$ and people with high results on both these scales $(\mathrm{N}=137-28 \%)$. These two groups are much more numerous than the remaining two (so-called "mixed"), as scales on which the category division was based were quite strongly correlated $(r=0.42 ; \mathrm{p}<0.001)$.

Table 3: Distribution of the category indicator of religious extremism divided into groups

\begin{tabular}{|l|cccc|c|}
\hline Groups & $\mathbf{( 1 )}$ & $\mathbf{( 2 )}$ & $\mathbf{( 3 )}$ & $\mathbf{( 4 )}$ & $\mathbf{N}$ \\
\hline Chechen refugees & 1 & 8 & 5 & 60 & 74 \\
Non-Chechen refugees & $1.4 \%$ & $10.8 \%$ & $6.8 \%$ & $81.1 \%$ & \\
& 34 & 21 & 8 & 18 & 81 \\
Polish Muslim & $42 \%$ & $25.9 \%$ & $9.9 \%$ & $22 \%$ & \\
Polish non-Muslim & 53 & 5 & 34 & 18 & 110 \\
& $48.2 \%$ & $4.5 \%$ & $30.9 \%$ & $16.4 \%$ & \\
Muslim foreign students & 67 & 8 & 30 & 13 & 118 \\
& $56.8 \%$ & $6.8 \%$ & $25.4 \%$ & $11 \%$ & \\
Non-Muslim foreign & 5 & 16 & 13 & 24 & 58 \\
students & 14 & $27.6 \%$ & $22.4 \%$ & $41.4 \%$ & \\
& $29.8 \%$ & $51.1 \%$ & $12.8 \%$ & $6.4 \%$ & 47 \\
\hline
\end{tabular}

Legend: (1) low fundamentalism, low approval of violence; (2) low fundamentalism, high approval of violence; (3) high fundamentalism, low approval of violence; (4) high fundamentalism, high approval of violence (= religious extremism).

Table 3 shows the distribution of four categories of the extremism indicator in six examined groups. The results only prove the observations from the previous 
examination. Assuming that the group of people who are most prone to religious extremism consists of those with high results on religious fundamentalism scale and approval of religious violence scale (category no. 4), we may recognize two such groups. They are, first of all, Chechen Muslims (over $80 \%$ of them are placed in category no. 4) and, to a lesser degree, Muslim foreign students ( $40 \%$ of them belong to that category). In both groups mentioned, people of "increased risk" constitute the dominating category, and the category of "low risk" is the least numerous ( $1.4 \%$ and $8.6 \%$ respectively). The remaining groups are dominated by people belonging to the "low risk" category. Their convictions rather exclude tendency to religious extremism, except for non-Muslim students, who strongly approve religious violence even if reject fundamentalist convictions.

\section{Feeling of collective harm vs. religious extremism}

For the purpose of the research, it has been assumed that one of the most important psychological sources of religious extremism may be the feeling of collective harm. This feeling stems from the conviction that in the Republic of Poland there are unfavorable conditions for the development of a given religion. In order to gain the reference criterion for the assessment of this hypothesis, the respondents expressed their opinions on conditions for development of Islam, Catholicism, Protestantism, Orthodox Church and Judaism. Figures 8 and 9 present the results of comparisons.

Figure 8: Conditions for development of a given religion in Poland (1-10) N=534

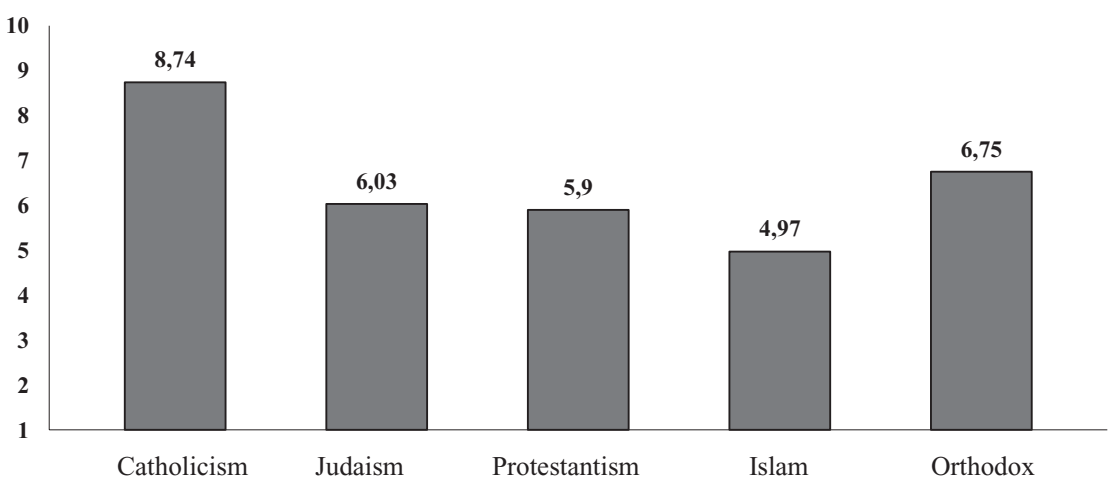

Explanation: Arrows indicate statistically significant differences among groups amounting to $\mathrm{p}<=0.05$

Compliant to the results presented in Figure 8, the respondents feel that Catholicism may expect the most advantageous conditions for development, while Islam besets most barriers. 
Figure 9: Conditions for development of Islam in Poland (1-10)

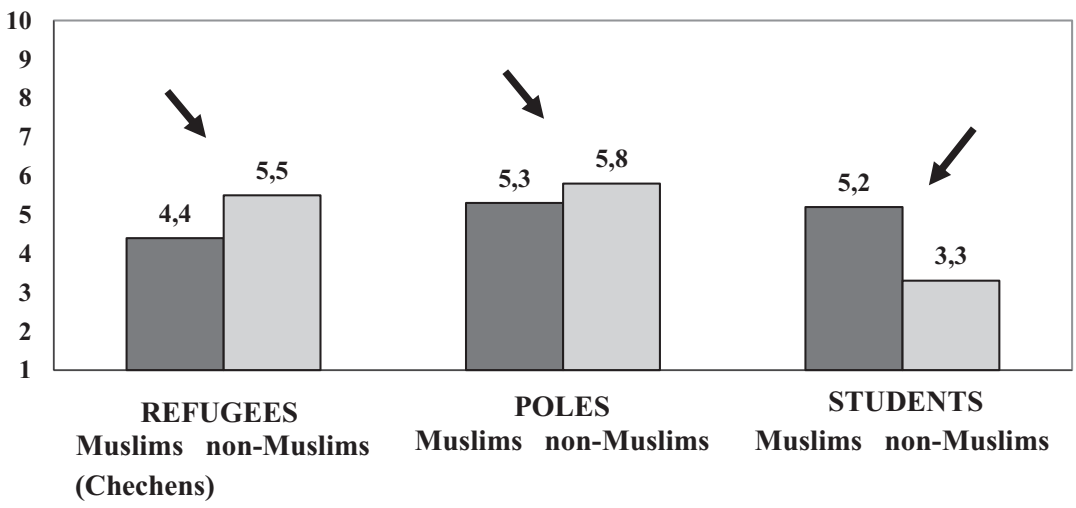

Explanation: Arrows indicate statistically significant differences among groups amounting to $\mathrm{p}<=0.05$

Data in Figure 9 presents quite surprising results. Muslim refugees find the conditions for development of Islam in Poland as worse than they are assessed by their counterpart group of non-Muslim refugees $(M=4.4$ and $M=5.5 ; t=-2.6 ; p<0.01$ respectively). In Polish Muslims' opinion, the conditions in dispute are worse than Catholic or aconfessional Poles find them $(M=5.3$ and $M=5.8 ; t=3.3 ; p<0.01$ respectively). According to non-Muslim students, conditions for development of Islam in Poland are worse than in the opinion of Muslim students $(\mathrm{M}=3.3$ and $\mathrm{M}=5.2 ; \mathrm{t}=-3.9 ; \mathrm{p}<0.01$ respectively). Surprisingly, they assess it on the worst level from among all the examined groups.

The following stage of statistical analysis verified the relation between the assessments of conditions for the development of Islam in Poland and religious extremism with recognition of the quantity indicator (I). Table 4 presents the results:

Table 4: $r$-Pearson's correlation among the assessments of conditions for the development of Islam and religious extremism (indicator I)

\begin{tabular}{|l|ccc|}
\hline \multicolumn{1}{|c|}{$\mathbf{N = 2 6 6}$} & $\begin{array}{c}\text { Religious } \\
\text { fundamentalism }\end{array}$ & $\begin{array}{c}\text { Approval of } \\
\text { religious violence }\end{array}$ & $\begin{array}{c}\text { Religious extremism } \\
\text { (indicator I) }\end{array}$ \\
\hline Total & $-0.15^{*}$ & $-0.22^{* *}$ & $-0.22^{* *}$ \\
Chechen refugees & 0.08 & -0.07 & 0.02 \\
Muslim Poles & -0.16 & -0.15 & -0.16 \\
Muslim students & -0.07 & -0.09 & -0.12 \\
\hline
\end{tabular}

Explanation: $* \mathrm{p}<=0.05 ; * * \mathrm{p}<=0.01$ 
In the examined group of Muslims $(\mathrm{N}=266)$, strong feeling of collective harm goes together with statistically significant level of religious fundamentalism $(\mathrm{r}=-0.15)$, approval of religious violence $(r=-0.22)$ and religious extremism $(r=-0.22)$. However, what needs to be pointed out, on the level of the group, is that those correlations are reproduced with comparable force only in the group of Muslim Poles (however, due to smaller numbers they are not statistically significant). Therefore, the detected correlation should not be treated as universal.

Table 5: Mean assessments of conditions for the development of Islam in Poland in four categories of extremism indicator (indicator II) - for the combined group of Islam followers

\begin{tabular}{|l|cccc|c|}
\hline $\mathbf{N}=\mathbf{2 6 6}$ & $\mathbf{( 1 )}$ & $\mathbf{( 2 )}$ & $\mathbf{( 3 )}$ & $\mathbf{( 4 )}$ & Total \\
\hline Chechen refugees & 2.0 & 4.0 & 6.3 & 4.2 & 4.4 \\
Muslim Poles & 6.4 & 5.6 & 5.4 & 5.3 & 5.8 \\
Foreign Muslim students & 6.4 & 6.0 & 5.6 & 4.4 & 5.2 \\
\hline Total & 6.3 & 5.4 & 5.5 & 4.5 & 5.3 \\
\hline
\end{tabular}

Legend: (1) low fundamentalism, low approval of violence

(2) low fundamentalism, high approval of violence

(3) high fundamentalism, low approval of violence

(4) high fundamentalism, high approval of violence

Table 5 comprises a detailed analysis of relations among the assessment of conditions for development of Islam and extremism measured with the category indicator. It had been expected that the highest assessment would appear among Muslims in the "low risk" category (1) and the lowest (signifying the strongest feeling of harm) in the category of "increased risk" (4). In fact, this type of pattern of results appears in the combined group of Muslims $(M=6.3$ and $M=4.5$, respectively). It is also reproduced in two subgroups - among Muslim Poles and among Muslim students (in case of Chechen refugees it is difficult to take into consideration the "low risk" category, because it comprises only one person).

Relations between religious extremism and beliefs about oneself and the social world

It had been presumed that individual differences in the level of religious extremism might be strongly related to a group of psychological variables describing one's beliefs about themselves and the world they live in. In the group of those variables, the following dimensions are present: authoritarianism, legitimization of socio-political system, social cynicism, political cynicism, trust in people, close contacts and the assessment of own life quality. 
To find out which of the aforementioned variables are the predictors of religious extremism, regression analysis realized with the method of step analysis was conducted and its results are shown in Table 6. In the Table values for the r-Pearson correlation coefficients are presented together with the standardized beta regression coefficients. In the calculation the religious extremism quantity indicator was used (indicator I).

Table 6: Predictors of religious extremism in regression analysis (indicator I)

\begin{tabular}{|l|c|c|}
\hline Predictors & r & $\boldsymbol{\beta}$ \\
\hline Authoritarianism & $0.43^{* *}$ & $0.40^{* *}$ \\
Legitimisation of the system & 0.00 & - \\
Social cynicism & $0.25^{* *}$ & - \\
Political cynicism & 0.07 & - \\
Social trust & $-0.13^{* *}$ & - \\
Close contacts with people & $-0.18^{* *}$ & $-0.10^{*}$ \\
Assessment of own life & $-0.21^{* *}$ & $-0.09^{*}$ \\
\hline
\end{tabular}

Explanation: ${ }^{*} \mathrm{p}<=0.05 ; * \mathrm{p}<=0.01$

Compliant to findings in Table 6, the factors that trigger the growth of extremism the most are high level of authoritarianism $(r=0.43)$ and social cynicism $(r=0.25)$. Moreover, it is also related to lack of satisfaction about one's own life $(r=-0.21)$, lack of social trust $(\mathrm{r}=-0.13)$ and poor relationships with other people $(\mathrm{r}=-0.18)$.

Because of the fact that the picture of dependences linking religious extremism with a group of psychological variables is distorted by their mutual correlation, it was necessary to employ multiple analysis of step regression (see: standardized coefficients of $\beta$ regression in Table 6). This method shows the relations in a more reliable manner. Among seven potential extremism predicates, only three are comprised in the regression equation: strong authoritarianism $(\beta=0.40)$, poor human relationships $(\beta=-0.10)$ and negative assessment of own life's quality $(\beta=-0.09)$. Altogether they explain $21 \%$ of variance of the dependent variable. After excluding co-linearity effects, the relations between extremism, social cynicism and trust in people turned out to be statistically insignificant, which means that their statistical significance on the level of $r$ coefficients constitutes first of all the result of correlation with authoritarianism.

The analyses have been conducted for the second time with the use of category indicator of extremism. Due to the fact that the nominal nature of this indicator excluded the application of multiple regression analysis, it was necessary to use the 
discriminant analysis as the most adequate method. The discriminant analysis is a statistical method which allows examining differences among groups of objects based on a set of selected independent variables (predictors). Linear combination of independent variables (discriminant function) constitutes its core; it makes possible to classify the examined people to one of the groups constituting the researcher's object of interest. The stronger "discriminant power" the variables have, the more efficient the model they form is.

Table 7: Predictors of religious extremism (indicator II) in the discriminant analysis $-\beta$ and $r$ coefficients

\begin{tabular}{|l|c|c|}
\hline & $\boldsymbol{\beta}$ & $\mathbf{r}$ \\
\hline Authoritarianism & 0.89 & $0.93^{* *}$ \\
Legitimization of the system & 0.19 & 0.07 \\
Social cynicism & -0.03 & $0.52^{* *}$ \\
Political cynicism & 0.09 & 0.06 \\
Social trust & -0.18 & $-0.31^{* *}$ \\
Close contacts with people & -0.13 & $-0.30^{* *}$ \\
Assessment of own life & -0.18 & $-0.42^{* *}$ \\
\hline
\end{tabular}

Explanation: $* \mathrm{p}<=0.05 ; * * \mathrm{p}<=0.01$

If the grouping variable divides the examined people into two groups, one discriminant function occurs. If there are more such groups, the number of functions grows compliant to the $\mathrm{k}-1$ rule ( $\mathrm{k}$ - number of groups). The category indicator of extremism breaks down the examined number of people into four groups, which means that for its full description three functions are needed. However, the mechanism of forming discriminant functions implies the following regularity - first function absorbs the biggest amount of intergroup variance, and every further occurring function combines certain amount of variance which was not explained by previous functions. In the discussed case, the first function explains about $80 \%$ of the intergroup variance and this function only comprises adequately high resources of information allowing for at least partial explanation of differences among groups (the remaining functions are not statistically significant).

In Table 7, discriminant coefficients specifying the quantity share of particular predictors in the first function are shown. The highest independent impact on the discriminant function results has authoritarianism $(B=0.89)$, then, in a slighter degree, legitimization of the system $(B=0.19)$, lack of trust in people $(B=-0.18)$, dissatisfaction with own life $(B=-0.18)$ and poor relationships with other people $(\mathrm{B}=-0.13)$. The results of social and political cynicism are marginal. 
Aiming at specification of relations linking discriminant variables with the function, it is also possible to verify the structure of the matrix (r) showing the size of the correlation among predictors and the function. Conclusions are that it shows only partially the results which are already known. Definitely, unusually strong, positive correlation with authoritarianism $(\mathrm{r}=0.93)$ is dominating. Negative correlations with satisfaction with own life $(\mathrm{r}=-0.42)$ trust in people $(\mathrm{r}=-0.31)$ and quality of relationships with other people $(\mathrm{r}=-0.30)$ are much weaker but very clear. Consequently, the impact of political cynicism is also statistically insignificant. However, one important difference can be observed between the two columns of coefficients and it is the role of social cynicism. Standardized coefficient for this variable amounts to -0.03 indicating that it has no link to the discriminant function. However, the structure matrix coefficient amounts to 0.52 , suggesting that this correlation is very strong. Attention should also be paid to the second noticeable discrepancy - contrary to what is suggested by the value of $\beta$ coefficient, legitimization of the system seems to remain in no relation with the function ( $\mathrm{r}=0.06$ ). Indicating differences among $\beta$ and $\mathrm{r}$ coefficients is important in the context of interpretation of psychological impact of discriminant function.

The $\beta$ and $r$ coefficients show something different to a certain degree. The $\beta$ coefficient presents the role of a given predictor in calculating the discriminant result at the control of its co-function analysis with other predictors. The $\mathrm{r}$ coefficient is a simple two-function analysis correlation, irrespective of relations with other variables. Due to certain reasons, the description of which may be skipped at this point, coefficients of structures are recommended as a better tool of interpretation of discriminant function than standardized $\beta$ coefficients.

The discriminant function has the nature of latent variable. It is a more general dimension, in mathematical manner synthesizing the most important information carried by forming it predictors. How should its psychological sense be interpreted? It seems that it is difficult to ascribe one superior label to it. It is rather formed by two separate in quality "mental features" (which is certainly to a large extent the derivative of this particular selection of discriminant variables). If the absolute value of the coefficient from the structure matrix ( $r$ ) is very high (about +1.0 or -1.0 ), the function contains nearly the same information as the variable. Therefore it is obvious that its basic element is the authoritarian vision of social world (hierarchical perception of human relationships, fascination and submission toward authorities) completed with (both variables correlate on the level of $\mathrm{r}=0.60$ ) social cynicism (conviction that humanist and pro-social values are nonfunctional "in life") and generalized lack of trust in people. The second noticeable ingredient of function may be specified as low mental wellbeing, expressed in dissatisfaction with own life and social alienation. 
Figure 10: Mean values of discriminant functions in four categories of the religious extremism (indicator II)

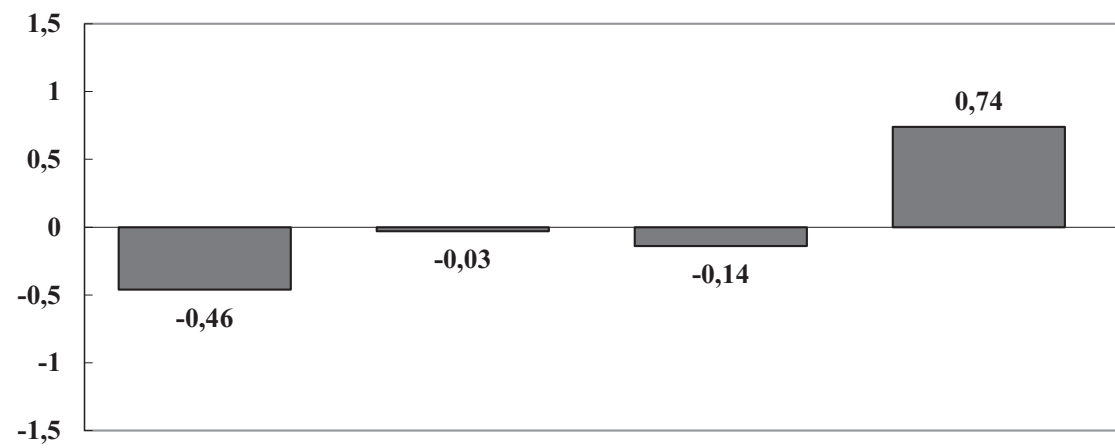

LOW fundamentalism LOW approval of violence

HIGH fundamentalism HIGH approval of violence

Explanation: Arrows indicate statistically significant differences among groups amounting to $\mathrm{p}<=0.05$

The results in figure 10 indicate that the biggest discrepancies occur between people with high level of fundamentalism and the approval of religious violence (the value of the function is clearly the highest.- $M=0.74$ ) and the group with low level of both variables mentioned (the value of the function is the lowest $\mathrm{M}=-0.46$ respectively).

Figure 11: Mean values of the discriminant function broken down into groups of the respondents

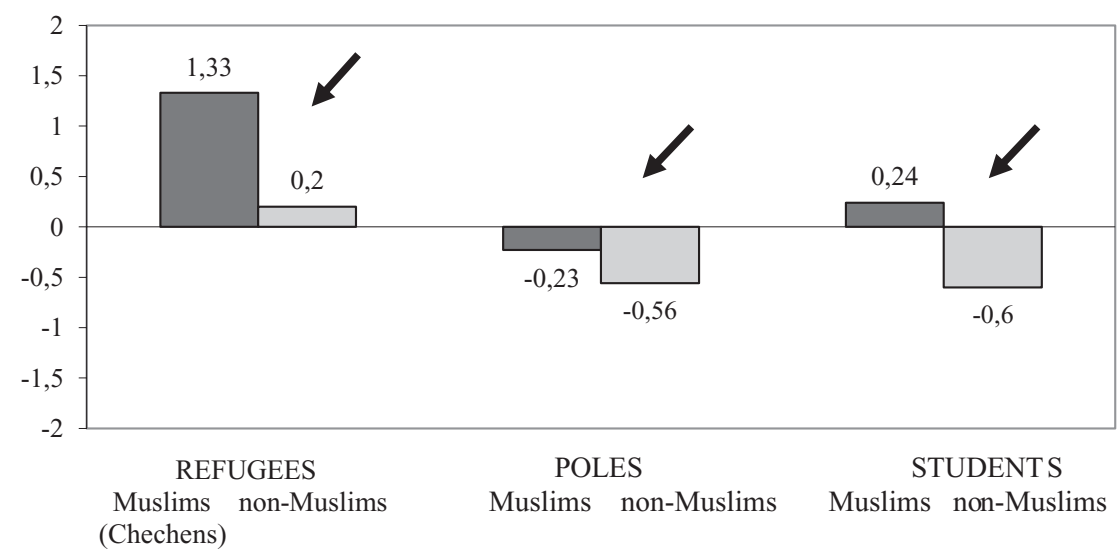

Explanation: Arrows indicate statistically significant differences among groups amounting to $\mathrm{p}<=0.05$ 
The conclusion of the discriminant function is that the people with the highest level of authoritarianism and the lowest mental wellbeing belong to the group that may pose the highest threat of religious extremism. Moreover, the distribution of results in Figure 11 was easy to foresee. It shows mean values of the discriminant function broken down into groups of respondents. As it was expected, the basic components characterizing people achieving high results on this function (high authoritarianism and low mental wellbeing) are representative for refugees from Chechnya.

\section{Conclusion}

Islam followers, who stay and live on the territory of the Republic of Poland, often declare authoritarian vision of social world, feel alienated because of their cultural background and are generally dissatisfied with their own lives. Most of them are Chechen refugees. These people constitute the group of potentially highest risk of religious extremism. Strong inclination to extremist opinions is also noticed among Muslim students, which is particularly disquieting due to their high status of education gained in one of the EU countries.

Polish Muslims (mainly Polish Tartars) may present nearly the same level of religious extremism threat as Poles who declare to be other than Islam denomination. In all groups of Islam followers in Poland (including Chechen refugees) the acceptance of political violence is insignificant. However, we should bear in mind that it does not concern the religious extremism layer, which increase may pose a problem in the future (e.g. among refugees from Chechnya).

The factor (predictor) that might trigger religious violence among the group of Islam followers is the feeling of collective harm. In case of the RP it may stem from subjective belief that this religion has rather poor conditions for development. The attempts to solve the problem by facilitating religious practices for Islam followers in Poland could reduce the threat of religious extremism, however, we should keep in mind that in countries such as Great Britain or Holland, where conditions for the development of Islam were unusually good, radicalization could not be avoided and a series of terrorist attacks took place.

Apart from dissatisfaction with one's own life and poor human relationships, the approval of religious extremism is also fostered by anti-democratic attitudes (authoritarianism). Islam followers perceive the world by the culture and customs they were raised in. Needless to say that political systems of that countries are far from democratic. Muslims often remain in close contact with the relatives in the countries of their origin which may bring the danger of submission to local Islam fundamentalists' influence. This specific socio-cultural layer does not have 
to have negative impact on the Muslim community in Poland but it may become a radicalization factor.

It is commonly known that for all the examined cases there is no one sociopsychological profile that makes possible to isolate in future threatening individuals form the community or allow to reduce factors which draw attention to radical slogans. Every such person may be driven by specific motives. However, a certain set of factors correlated with various manners may result in higher inclination at a given moment of life of such an individual to the ideology of Islam in its most orthodox and distorted form calling directly to extreme violence.

\section{References}

B. Altemeyer, B. Hunsberger, Authoritarianism, religious fundamentalism, quest, and prejudice, The International Journal for the Psychology of Religion, no. 2, 1992.

B. Altemeyer, The Authoritarian Specter, Harvard University Press, London 1996.

B. Altemeyer, B. Hunsberger, Fundamentalism and authoritarianism, in: Handbook of the Psychology of Religion and Spirituality R.F. Palotzian, C.L. Park (eds.), Guilford Press, New York 2005.

B. Altemeyer, B. Hunsberger, A revised Religious Fundamentalism Scale: The short and sweet of it, The International Journal for the Psychology of Religion, no. 14, 2004, pp. 47-54.

A. T. Beck, Prisoners of hate. The cognitive basis of anger, hostility, and violence, Harper Collins Publishers, New York 1999.

B. Bolechow, Terroryzm, Wydawnictwo PWN, Warsaw 2010.

P. Boski, J. Więckowska, M. Biłas-Henne, Cynicism in Love and in Politics, in: Psychological aspects of social axioms K. Leung, M. H. Bond (eds.), Springer Verlag, New York 2008.

J. Horgan, Psychologia terroryzmu, Wydawnictwo PWN, Warsaw 2008.

U. Jakubowska, Ekstremizm polityczny, Gdańskie Wydawnictwo Pedagogiczne, Gdansk 2005.

U. Jakubowska, W. Oniszczenko, Genetyczne i psychospołeczne uwarunkowania postawy fundamentalistycznej religijnie, in: Przekonania w żciu jednostek, grup, społeczności A. Cisłak, K. Henne, K. Skarżyńska (eds.), Academica Wydawnictwo SWPS, Warsaw 2009.

U. Jakubowska, J. Reykowski, P. Radkiewicz, P. Boski, K. Korzeniowski, B. Wojciszke Ekstremizm religijny wśród wyznawców islamu mieszkających w Polsce. Raport z badań (typescript). 
J. W. Jones, Why does religion turn violent? A psychoanalytic exploration of religious terrorism, "Psychoanalitic Review" no. 93, 2006.

A. C. Kay, J.T. Jost, Complementary justice: Effects of "poor but happy" and "poor but honest" stereotype exemplars on system justification and implicit activation of the justice motive, Journal of Personality and Social Psychology no. 85, 2003.

P. M. Sniderman, A question of loyalty, University of California Press, Berkeley 1981.

D. Szlachter, Walka $z$ terroryzmem $w$ Unii Europejskiej - nowy impuls, Wydawnictwo Adam Marszałek, Toruń 2007.

K. Kaniasty, Klęska żywiołowa czy katastrofa społeczna? Psychospołeczne konsekwencje polskiej powodzi 1997 roku, Gdańskie Wydawnictwo Pedagogiczne, Gdansk 2003.

K. Korzeniowski, O wielowymiarowości autorytaryzmu, in: Demokracja w Polsce. Doświadczanie zmian U. Jakubowska, K. Skarżyńska (eds.), Academica Wydawnictwo SWPS, Warsaw 2005. 


\section{Andrzej Misiuk and Magdalena Dobrowolska-Opała Terrorist Threats and Mass Events}

\section{Introduction}

The threat of terrorist acts is presently one of the most readily-discussed topics; as it is a highly salient media topic, it makes its way easily into print media, the Internet and books. Applying the simplest search algorithm, simply entering the word "terrorism" into a search engine, we generate 104.000 .000 hits. $^{1}$ The international community, including Poland, keeps track of the information and literature being produced on both the subject of terrorism itself and activities associated with terrorism prevention. Such intense interest, however, leads to ambivalent effects. On the one hand, education and knowledge are favorable to prevention, while on the other, the spread of their message aids terrorists in pursuing their aims, especially those of achieving their badly-needed publicity, generating widespread fear, not only in the places where attacks occur. To paraphrase the oft-cited Brian Jenkins, it should be emphasized that terrorism is a theatre addressed to those who are watching. The direct victims are essentially actors, ${ }^{2}$ pressed unwillingly into provoking fear and trauma among the audience. This characteristic is emphasized here for a reason - the theaters of the $21^{\text {st }}$ century are places whose high mediality and symbolism are, for terrorists and observers alike, unambiguous. Such places undoubtedly include mass events, particularly those organized at stadiums and other large structures (congress halls, concert venues, etc.). They are attractive targets, something demonstrated by the most recent attacks in Paris.

In Poland, concern for the safety of mass parties, including with respect to the terrorist threat, is visible at the level of domestic regulation, international cooperation, and the activities of Member States within the European Union and the Council of Europe. Nevertheless, there are serious doubts arising out of the level of interest in counteracting potential attacks, and its translation into action plans

1 As of 28 December 2015.

2 B. M. Jenkins, International Terrorism: A New Mode of Conflict, in: International Terrorism and World Security D. Carlton, C. Schaerf (eds.), Croom Helm Ldt., London 1976, cited by: K. Liedel, Zwalczanie terroryzmu międzynarodowego w polskiej polityce bezpieczeństwa, Wydawnictwo Difin, Warsaw 2010, p. 27. 
in the event such attacks occur. While the first stage is measurable, the second gives rise to significant uncertainty, and it would be better if the need to implement them never arose.

\section{Domestic Regulations Addressing Terrorist Threats which may arise in Conjunction with Mass Events}

In Poland, the most important document concerning safety at mass events is the Mass Events Act of 20 March 2009. ${ }^{3}$ Under the provisions of this act, a mass event is a sporting event (including football match) or an artistic-entertainment event (including organized, public screenings of television transmissions on screens and/or devices facilitating the projection of an image with a diagonal in excess of 3 meters) at which the number of places made accessible, depending on the type of event, is between 300 to 1000 . The location of the event is also important, and the Act offers the following categorization: site, stadium, other premises which do not constitute a building, sports arena and other sports premises. ${ }^{4}$ The wording of the Act does not directly address the issue of terrorist threats, nor criminal acts perpetrated by so-called "ultras" or hooligans. In respect of the latter groups, it is no great challenge to find normative material designed to reduce the frequency of such occurrences. Significantly, a portion of those regulations may also be of assistance in countering the threat of terrorist attacks.

The starting point for the divagations to be undertaken in the article are two particular statutory provisions. The first concerns the organizer's responsibility for safety of a mass event at its location and for its duration. ${ }^{5}$ The second imposes on authorities - such as mayors and prefects, the provincial governor, the Police, the State Fire Brigade, the health service and other appropriate authorities - the obligation to secure such an event in the scope set out in the Mass Events Act and other relevant regulations. ${ }^{6}$ However, it should be kept in mind that it is primarily the organizer who bears responsibility for the safety of the event's participants, for the protection of public order, and for securing access to medical assistance. ${ }^{7}$

3 Ustawa z dnia 20 marca 2009 r. o bezpieczeństwie imprez masowych, Dz.U. 2009 no. 62 item 504 with amendments.

4 Ibid. Art. 3 (1-4).

5 Ibid. Art. 5 (1).

6 Ibid. Art. 5 (3).

7 Ibid. Art. $5(2)(1-3)$. 
The aforementioned entities are required to support the organizer and complement its activities by, for example, being active in the public space adjacent to the mass event (Police), or by inspecting the site/structure for fire safety issues (State Fire Brigade). The oversight authority given to mayors and prefects is also significant, and it includes the right to refuse to issue a permit for a mass event ${ }^{8}$ and to interrupt the event if it is ascertained that the conditions set out in the permit are broken. Another important role belongs to the provincial governor, who may forbid a mass event from being held with public participation either in an entire structure or in specified sectors of it, ${ }^{9}$ or interrupt the event in the occurrence of a threat to human health or life, or to property of significant value. ${ }^{10}$ In the practice of organizing mass events in Poland, particularly those related to sports, the policing element is clearly dominant, owing to detailed risk analyses and information acquired through operational and investigative activities. Unfortunately, there is little activity involving factors directly associated with the organizer. For example, in Poland there is no official association of safety directors, where people could exchange information or undertake systematic cooperation with the Police. These types of solutions are in place e.g. in England and Wales, where safety directors are associated within the Football Safety Officers Association. The FSOA has created an Internet platform allowing safety officers to create pre-match, match and post-match reports, which include information about incidents involving hooliganism, fan behavior, and action taken. This massive database created by experts is a source of useful information and viewpoints which frequently serve as complements or alternatives to police sources.

The organizer does not independently ensure safety - he/she nominates a safety director who represents the organizer in respect of ensuring the safety of participants in the mass event ${ }^{11}$. This director, in turn, exercises authority over stewarding and informational services. The first is associated with the use of force in ensuring security - its members must figure in the register of qualified physical security specialists. Under the Act on Protection of People and Property, an entry on that list gives the right to engage in activities related to protection of people and property undertaken in the form of direct physical security:

8 Ibid. art. 24, art. 29 (1 and 4).

9 Ibid. art. 34 (1)(1).

10 Ibid. art. $34 \mathrm{a}(1)$.

11 Ibid. art. 3 (11). 


\section{permanent or temporary;}

consisting in the continual monitoring of signals sent, gathered and processed in electronic devices and alarm systems;

consisting in transport of cash and other valuable and/or dangerous items. ${ }^{12}$

In reference to the indicated forms of activity which correspond to particular experience and skills, the aforementioned requirement of certification should be considered appropriate for those engaged in stewarding services, as they function in service of public safety and order for the duration and in the vicinity of a mass event. ${ }^{13}$

In the majority of cases, this formation is the first line of defense when threats arise, including terrorist threats. The second type of service, i.e. information, ensures security primarily by providing information to participants regarding organizational solutions that have been adopted. ${ }^{14}$ Both services are obliged to be distinguished by signage, and to undergo training whose subject matter is set out in the schedule to the ministerial regulation issued pursuant to the Mass Events Act. ${ }^{15}$ The same obligations rest on the safety director. The difference between this individual and the services under him relate solely to the scope of training which must be undergone, which is naturally far broader for a director: both in terms of hours (50 versus 24 for services) ${ }^{16}$ and subject matter. Significantly, the issue of terrorist threats is directly mentioned only in the directors' training curriculum in module VI titled "Securing mass events". It lasts only 4 hours and encompasses nine subjects, one of which is called "Counteracting terrorists threats". This is accompanied by such important issues as monitoring mass events, the rules for threat analysis, and calculation and dislocation of forces and resources. Assuming that the individual conducting the training allocates the same amount of time to each one, this amounts to 27 minutes per subject. This is not sufficient time even for providing the attendees with a general overview of the issue. Other closely related issues, which the directors must study, include evacuation of mass event participants ( 2 hours) and tasks of the services at the disposal of the organizer,

12 Ustawa z dnia 22 sierpnia 1997 r. o ochronie osób i mienia, Dz.U. 1997 no. 114 item 740 with amendments, art. 3 (1) and art. 26 (1).

13 Ustawa z dnia 20 marca 2009 r. o bezpieczeństwie imprez ...op.cit., art. 19 (1).

14 Ibid. art. 19 (2).

15 Rozporządzenie Rady Ministrów z dnia 30 sierpnia 2011 r. w sprawie wymogów, jakie powinni spełniać kierownik do spraw bezpieczeństwa, służby porządkowe i służby informacyjne, Dz.U. 2011 no. 183 item 1087.

16 Rozporządzenie Rady Ministrów z dnia 30 sierpnia 2011 r. w sprawie wymogów... op.cit., schedule no. 1, p. 4 schedule no. 2, p. 2. 
which should include discussion of inspection of participants and search of their bags and clothing. These are, however, secondary issues related to a range of threat types, ${ }^{17}$ not dedicated exclusively to the issue of terrorist attacks. Assumptions as to the preparation of internal reaction plans taking into account the specificities of particular sites and events would seem obvious. It is difficult to say, however, to what extent they are professionally prepared and adapted to dynamically occurring changes. Nevertheless, the lack of detailed regulations would seem like a clear case of extreme negligence.

One procedure that may be applied in the event of a terrorist-type threat is an appeal by the organizer or the safety director to the Police or the Gendarmerie ${ }^{18}$ for help. In accordance with the Act, this can occur when activities of the steward service, taken within the framework of its authority, are ineffective. ${ }^{19}$ It should be assumed that a terrorist attack may constitute grounds for the Police or the Gendarmerie to be handed control. The exceptional nature of the situation and the need to employ exceptional force and measures render it necessary to shift the burden of providing security from the director to one of the aforementioned entities. All the more so that the entry of the Police or Gendarmerie allows functionaries to employ the full range of measures afforded to them under the provisions of the Police $\mathrm{Act}^{20}$ and the Act on the Gendarmerie and Military Safety Organs. ${ }^{21}$ There is a significant gap in the form of regulation concerning the presence of the Police and Gendarmerie in the vicinity of a stadium. As functionaries must be able to quickly assume command when a need arises, they should be nearby and prepared to engage immediately. Time is of the essence in such situations: rapid intervention is crucial in minimizing losses and risk.

Desiring to explore in detail the issue of the Police providing assistance to the organizer of a mass event, one should refer to the Police Act, which contains a provision allowing for support to be given to functionaries by the Armed Forces

17 Such threats include fire, panic, attempts to smuggle in pyrotechnics and alcohol.

18 Applying to the Gendarmerie (rather than the Police) for assistance is only possible when the mass event is being conducted at sites which are managed by units under the authority of the Minister of National Defense. See: Ustawa z dnia 20 marca 2009 r. o bezpieczeństwie imprez ...op.cit., art. 22 (5).

19 Ibid. art. 22 (4 and 5).

20 Ustawa z dnia 6 kwietnia 1990 r. o Policji, Dz.U. 1990 no. 30 item 179 with amendments.

21 Ustawa z dnia 24 sierpnia 2001 r. o Żandarmerii Wojskowej i wojskowych organach porządkowych, Dz.U. 2001 no. 123 item 1353. See: C. Kąkol, Bezpieczeństwo imprez masowych. Komentarz, Wolters Kluwer, Warsaw 2012, p. 303. 
of the Republic of Poland. A condition of exercising this possibility is the appearance of a threat to public safety or public order through the emergence of one or more of the threats enumerated therein. These include the danger of commission of a terrorist act or its commission in respect of facilities of particular significance for state security and/or defense, or which can threaten the safety of human life. ${ }^{22}$ Units of the Armed Forces of the Republic of Poland may only be employed when the Police has proven insufficient. ${ }^{23}$ The decision on their use is taken by the President of Poland by way of a determination issued on application by the Prime Minister. In urgent cases, the decision to provide assistance is taken by the Minister of National Defense on application from the minister responsible for home affairs, who immediately informs of such the President of Poland and the Prime Minister. ${ }^{24}$ The detailed conditions and manner in which units of the Police and the Armed Forces may be engaged, coordination of joint activities, and the manner in which information is exchanged have been laid down in a Regulation of the Council of Ministers, pursuant to the relevant statutory authorization. ${ }^{25}$ One of its most important provisions is the regulation concerning the coordinating authority, who, depending on the area, is: the regionally appropriate provincial Chief of Police (in respect of action undertaken by the Police and the Armed Forces of the Republic of Poland within the territory of one province) or the National Chief of Police (when activity is undertaken in an area covering the territory of more than one province). ${ }^{26}$

In summary, emphasis should be placed on the generalized character of domestic regulations, which are perhaps not entirely aligned with the rapid changes and progressing evolution of the terrorist threat. The Mass Events Act provides the organizer and other entities active in that area (primarily the Police) with defined procedures. Just the application for a permit to hold a mass event triggers engagement in activities intended to have a significant effect on the safety of participants. The legislator's failure to explicitly address terrorist threats does not mean that no measures in that scope have been taken. The Act is intended to address all types

22 Ustawa z dnia 6 kwietnia 1990 r. o Policji...op.cit., art. 18 (1)(4).

23 Ibid. art. 18 (1).

24 Ibid. art. 18 (3 and 5).

25 Rozporządzenie Rady Ministrów z dnia 6 sierpnia 2013 r. w sprawie szczegółowych warunków i sposobu użycia oddziałów i pododdziałów Policji oraz Sił Zbrojnych Rzeczypospolitej Polskiej w razie zagrożenia bezpieczeństwa publicznego lub zakłócenia porządku publicznego, Dz.U. 2013 item 1037.

26 Rozporządzenie Rady Ministrów z dnia 6 sierpnia 2013 r. w sprawie szczegółowych... op.cit., art. 2 (1)(4). 
of threats, conceived in a generalized manner. In the future, however, at least partial regulation requiring organizers to engage in stronger efforts concerning this aspect of safety is needed. It is vital and urgent to expand the scope of training required for safety managers as well as steward and informational services. The issue of terrorist threats should not be taken lightly - they deserve more than 27 symbolic minutes of consideration.

\section{The EU Regulation Concerning Counteracting Terrorist Threats which may arise in Conjunction with Mass Events}

European Union law has not developed a single definition of mass event. In particular documents one may find terms such as "sporting event," "international sporting event," "international football match." From $1999,{ }^{27}$ the most prominent term was "football match of an international character," until 2010, when the term "international football match" was established, with the participation of at least one Member State. ${ }^{28}$ Differentiating football matches results from the popularity of that particular sport, and the concentration of threats associated with the activity and the movement of large groups of fans. Of significance were also the activities of the so-called hooligans and associated criminality, including organized crime. EU regulations are not limited to sport matches alone - in the majority of cases they are facultative, and can be applied during mass events of an artistic and recreational character, as well as other without an international component. An exception to this is the Decision of the Council on security in connection with football matches with an international dimension ${ }^{29}$ and its amendments in 2007, ${ }^{30}$ which require the creation of a national information point for football in every

27 This year saw the publication of Council Resolution of 21 June concerning an updated handbook with recommendations for international police cooperation and measures to prevent and control violence and disturbances in connection with football matches with an international dimension, in which at least one Member State is involved, Dz. U. L C 196 of 13.7.1999.

28 Council Resolution of 3 June 2010 concerning an updated handbook with recommendations for international police cooperation and measures to prevent and control violence and disturbances in connection with football matches with an international dimension, in which at least one Member State is involved, Dz. U. C 165 of 24.6.2010.

29 Council Decision of 25 April 2002 concerning security in connection with football matches with an international dimension, Dz. U. L 121 of 8.5.2002.

30 Council Decision of 12 June 2007 amending Decision 2002/348/JHA concerning security in connection with football matches with an international dimension, Dz. U. L 155 of 15.6.2007. 
Member State. National Football Information Points (NFIP) profile and exchange information concerning security of football matches - however, the common practice is operating the EU's systems in conjunction with national databases. In Poland's case, this is the National Information Point for Sporting Events, which is part of the structure of the National Police Headquarters. ${ }^{31}$ The situation in the United Kingdom is similar, where the United Kingdom Football Policing Unit is the body responsible for such activities as issuing stadium bans and coordinating policing efforts for foreign tournaments. ${ }^{32}$

Under the EU's regulations, the burden of ensuring security for mass events is concentrated on generally-defined threats, and in respect of football matches it emphasizes hooligan-related excesses. The existing procedures can, however, also be employed against threats of a terrorist nature. Although this is not stated explicitly, it should be assumed that information concerning such dangers would not go ignored. Networks of cooperating police liaison officers should, as a rule, be prepared for receiving and analyzing various types of data. The aforementioned suppositions would seem to be confirmed by the newest edition of a handbook with recommendations introduced via the Council Resolution of 3 June 2010 concerning an updated handbook with recommendations for international police cooperation and measures to prevent and control violence and disturbances in connection with football matches with an international dimension, in which at least one Member State is involved..$^{33}$ For the first time in the history handbooks with recommendations, there is a directly-articulated need for selection of the appropriate means of communication during exceptional situations that is, fighting terrorism. It is proposed that the existing network of liaison officers, or a selected, specialized officer as an intermediary. Capturing the issue even more precisely, there is also mention made of the present of a Europol liaison officer. The European Police Office has the authority to support Member States by supplying important information and analyses, as well as general assessments of

31 Krajowy Punkt Informacyjny ds. Imprez Masowych, O punkcie, informational bulletin, available at http://www.kpk.policja.gov.pl/kpk/o-punkcie/9,O-Punkcie.html, accessed 31 January 2015.

32 College of Policing, Policing football, available at https://www.app.college.police.uk/ app-content/public-order/policing-football/, accessed 31 January 2015.

33 Alongside the indicated handbook, the Council previously introduced three handbook: in 1999, 2001 and 2006, through resolutions Dz. U. C 196 of 13.7.1999, Dz. U. 22 of 24.1.2002, and Dz. U. 322 of 29.12.2006. 
threats concerning serious organized crime and terrorism. ${ }^{34}$ In circular No. 2 to the handbook under consideration a table has been attached with timelines for filling orders for the products and services of Europol. They include a General Terrorism Threat Assessment, (GTTA) and Updates to the GTTA.

Alongside the network of national informational points for football, cooperation between liaison officers, and handbooks with guidelines, an important element of European cooperation in tackling the terrorist threat is the Atlas network. ${ }^{35}$ It brings together central antiterrorist police units from all Member States. Among its primary objectives is the continual boosting of the professionalism of antiterrorism units through such means as joint training sessions, knowledge exchanges, and also support - particularly important in the case of large-scale terrorist threats. ${ }^{36}$ Plans for creating a cooperation platform appeared at the end of the $20^{\text {th }}$ century, finally crystalizing after the $9 / 11$ terror attacks in the form of a network called "Atlas". The network acts under the direction of the Police Chiefs' Task Group, which itself is funded and overseen by the European Commission's General Directorate for Home Affairs. ${ }^{37}$ At present, "Atlas" is home to five Working Groups: Buildings, Water, Transport, Aeroplanes and Entries. Two fora are under them in the hierarchy: Negotiators and Snipers. Their lower status results from the more modest funds spent on their activities. ${ }^{38}$

The "Atlas" Network is also engaged in fighting terrorist attacks which may occur in conjunction with mass events. In June 2009, three years before the EURO 2012 football tournament, the National Police Headquarters' web page wrote of plans for joint exercises and workshops focused around the Buildings Working Group. The final exercises were held on September $27^{\text {th }}-28^{\text {th }}, 2011$ at the National Stadium in Warsaw, as well as at other locations in and around the capital. They

34 Chapter I of the attachment to the Council Resolution of 3 June 2010 concerning an updated handbook with recommendations for international police cooperation.

35 The Polish literature employs the term Atlas task group. See: homepage of the Bureau of Anti-terrorist Operations: http://www.policja.pl/pol/kgp/biuro-operacji-antyter/ atlas/41550,Unijna-grupa-zadaniowa-quotAtlasquot.html, accessed 30 January. 2015.

36 Unijna grupa zadaniowa "Atlas", at the homepage of the Biura Operacji Antyterrorystycznych (Bureau of Anti-terrorist Operations), cited above.

37 R. Teichmann, The European Homeland Security State. EU Anti-Terror Drills and Fear Campaigns, Global Research, 23 April 2013, available at http://www.globalresearch. $\mathrm{ca} /$ the-european-homeland-security-state-eu-anti-terror-drills-and-fear-campaigns/5332564 accessed 30 December 2015.

38 Unijna grupa zadaniowa "Atlas", at the homepage of the Bureau of Anti-terrorist Operations, cited above. 
encompassed elements of red tactics, ${ }^{39}$ acting in conditions of contamination, and problem-solving in situations with hostages located in buildings and vehicles (coaches). Participating units came from Austria, Slovenia, Lithuania, Portugal and France. ${ }^{40}$

Poland is represented in the "Atlas" Network by the Bureau of Anti-terrorist Operations (BAO), a unit under the command of the Vice Chief of Police. ${ }^{41}$ In respect of its powers and training, the $\mathrm{BAO}$ is primarily designed for physical reaction to crisis situations, particularly those with a terrorist element. Additional tasks include training conducted for police forces and other entities (civilians). The subject matter of training encompasses the issue of terrorist threats and counteracting them. In recent years, emphasis has also been placed on social prevention associated with raising awareness of how terrorists operate and conduct their attacks. ${ }^{42}$

An Austrian initiative is significant from the perspective of the subject under discussion. That country's efforts led to the December $23^{\text {rd }}, 2008$ Council Decision on the improvement of cooperation between the special intervention units of the Member States of the European Union in crisis situation. ${ }^{43}$ Under this decision, Member States can provide support to one another in crisis situations by engaging special intervention units. ${ }^{44} \mathrm{~A}$ crisis situation here is defined as any situation in which the competent authorities of a Member State have reasonable grounds to believe that there is a criminal offense presenting a serious direct physical threat to persons, property, infrastructure or institutions in that Member State; in particular, the situations defined in Article 1(1) of Council Framework Decision 2002/475/JHA of 13 June 2002 on combating terrorism. ${ }^{45}$ Permissible forms of

39 Red tactics is a combination of battlefield medicine with storm tactics. See: B. Serniak, D. Rogoziński, Czerwona taktyka, Policja 997, February 2009, p. 1.

40 M. Piekarski, Polska: ćwiczenia w ramach ATLAS, available at http://www.special-ops. pl/aktualnosc/id276,polska-cwiczenia-w-ramach-atlas, accessed 30 December 2015.

41 Structure of the National Police Headquarters, at the official webpage http://www. info.policja.pl/inf/kierownictwo-i-struktu/struktura-kgp/86025,Struktura-KomendyGlownej-Policji. html, accessed 30 December 2015.

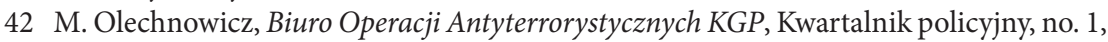
2015, p. 80.

43 Council Decision 2008/617/JHA of 23 June 2008 on the improvement of cooperation between the special intervention units of the Member States of the European Union in crisis situations, Dz. U. L 210/73 of 6.8.2008.

44 A special intervention unit is every unit for the protection of public order in a Member State that specializes in crisis situation management. See: Ibid. art. 2(a).

45 Ibid. art. 2 (b). 
assistance in joint interventions include supplying equipment, know-how, and operational engagement, including with the use of weapons. ${ }^{46}$ The entity providing assistance is obliged to follow the law in its host state, while the inviting state bears the costs of its intervention (unless the states agree otherwise) ${ }^{47}$

\section{Conclusion}

Summarizing the presented legal regulations and initiatives of the EU Member States, their general and imprecise nature should be kept in mind. This is required both by the specificities of the threat, as well as the undercover manner in which it is combatted. Additionally, Poland, as a country relatively free from such threats, does not seem to place adequate emphasis on securing mass events in this respect. The freedom of movement within the European Union, the migration crisis, and the activities of Daesh require and will likely continue to require increased engagement by security forces as well as the development of ever-newer solutions.

Key in the context of the subject matter under analysis is the issue of raising awareness among both organizers and participants of mass events. The organizer and the safety manager must recognize the importance of the role played by proper inspection of bags and clothes, specialist monitoring, and development and testing of response plans. These plans primarily involve reactions to bags left unattended, evacuation in the event of a detonation, and managing panicky crowds. Intensification of awareness-raising efforts among participants is vital, as well as a more in-depth discussion of terrorist threats in training courses for safety directors and members of both steward and information services. It would be advisable to conduct exercises at stadiums involving stewards and Police functionaries, including those from the Bureau of Anti-terrorist Operations. The selection and training of stewards is also important, as they are the first line of defense and reaction at a mass event when incidents occur. Preparation for potential terrorist threats should be given priority treatment with the full involvement of both state and private entities organizing and servicing mass events. The example of the November 2015 attacks in France demonstrates that terrorists see mass events as tempting targets, relatively soft, and efficient in creating shock and awe.

46 Ibid. art. 3 (1 and 2).

47 Ibid. art. 3 (3 and 6). 


\section{References}

Bureau of Anti-terrorist Operations, available at http://www.policja.pl/pol/kgp/ biuro-operacji-antyter/atlas/41550,Unijna-grupa-zadaniowa-quotAtlasquot. html, accessed 30 January 2015.

College of Policing, Policing football, available at https://www.app.college.police. uk/app-content/public-order/policing-football/, accessed 31 January 2015.

Council Resolution of 19 June 1999 concerning an updated handbook with recommendations for international police cooperation and measures to prevent and control violence and disturbances in connection with football matches with an international dimension, in which at least one Member State is involved, Dz. U. L C 196 of 13.7.1999

Council Decision of 25 April 2002 concerning security in connection with football matches with an international dimension, Dz. U. L 121 of 8.5.2002.

Council Decision of 12 June 2007 amending Decision 2002/348/JHA concerning security in connection with football matches with an international dimension, Dz. U. L 155 of 15.6.2007.

Council Decision 2008/617/JHA of 23 June 2008 on the improvement of cooperation between the special intervention units of the Member States of the European Union in crisis situations, Dz. U. L 210/73 of 6.8.2008.

Council Resolution of 3 June 2010 concerning an updated handbook with recommendations for international police cooperation and measures to prevent and control violence and disturbances in connection with football matches with an international dimension, in which at least one Member State is involved, Dz. U. C 165 of 24.6.2010.

B. M. Jenkins, International Terrorism: A New Mode of Conflict, in: International Terrorism and World Security D. Carlton, C. Schaerf (eds.), Croom Helm Ldt., London 1976, cited by: K. Liedel, Zwalczanie terroryzmu międzynarodowego w polskiej polityce bezpieczeństwa, Wydawnictwo Difin, Warsaw 2010.

C. Kąkol, Bezpieczeństwo imprez masowych. Komentarz, Wolters Kluwer, Warsaw 2012.

Krajowy Punkt Informacyjny ds. Imprez Masowych, O punkcie, informational bulletin, available at http://www.kpk.policja.gov.pl/kpk/o-punkcie/9,O-Punkcie.html, accessed 31 January 2015.

M. Olechnowicz, Biuro Operacji Antyterrorystycznych KGP, "Kwartalnik policyjny" no. 1, 2015.

M. Piekarski, Polska: ćwiczenia w ramach ATLAS, available at http://www.special-ops.pl/aktualnosc/id276,polska-cwiczenia-w-ramach-atlas, accessed 30 December 2015. 
Rozporządzenie Rady Ministrów z dnia 6 sierpnia 2013 r. w sprawie szczegółowych warunków i sposobu użycia oddziałów i pododdziałów Policji oraz Sił Zbrojnych Rzeczypospolitej Polskiej w razie zagrożenia bezpieczeństwa publicznego lub zakłócenia porządku publicznego, Dz.U. 2013 item 1037.

Rozporządzenie Rady Ministrów z dnia 30 sierpnia 2011 r. w sprawie wymogów, jakie powinni spełniać kierownik do spraw bezpieczeństwa, służby porządkowe i służby informacyjne, Dz.U. 2011 no. 183 item 1087.

B. Serniak, D. Rogoziński, Czerwona taktyka, "Policja 997” February 2009.

Structure of the National Police Headquarters, at the official webpage http://www. info.policja.pl/inf/kierownictwo-i-struktu/struktura-kgp/86025,Struktura-Komendy-Glownej-Policji.html, accessed 30 December 2015.

R. Teichmann, The European Homeland Security State. EU Anti-Terror Drills and Fear Campaigns, Global Research, 23 April 2013, available at http://www. globalresearch.ca/the-european-homeland-security-state-eu-anti-terrordrills-and-fear-campaigns/5332564, accessed 30 December 2015.

Ustawa z dnia 6 kwietnia 1990 r. o Policji, Dz.U. 1990 no. 30 item 179 with amendments.

Ustawa z dnia 22 sierpnia 1997 r. o ochronie osób i mienia, Dz.U.1997 no. 114 item 740 with amendments.

Ustawa z dnia 24 sierpnia 2001 r. o Żandarmerii Wojskowej i wojskowych organach porządkowych, Dz.U. 2001 no. 123 item 1353.

Ustawa z dnia 20 marca 2009 r. o bezpieczeństwie imprez masowych, Dz.U. 2009 no. 62 item 504 with amendments. 



\section{Claribel de Castro Sánchez}

\section{Security, Migrant Flows, and Terrorism in the European Area of Freedom, Security and Justice}

\section{Introduction}

The New York, Madrid and London terrorist attacks that took place in the early $21^{\text {st }}$ century revealed the necessity of a change in security strategy. Those events gave rise to a crisis of the concept of security that had been widely used until then. After those attacks, terrorism has become one of the greatest threats for both national and international Security. Experts in Strategic Studies, State Governments and International Organizations made it clear: the security policies and the security tools created during the $20^{\text {th }}$ century no longer work, as they were devised to confront more traditional threats to security. It seems that the "old models" are not working in the "new times." It is time to work on the Security Strategy for the Twenty-First Century. Two fundamental ideas must be underlined at the start: on the one hand, the types of threats have increased in number, and, on the other hand, the unilateral perspective is not enough to guarantee the security of States.

In this context, a new concept of Security is necessary. The need is for a concept out of which new strategies can emerge that are suitable for confronting both current and future threats. The economic, technological, and social changes have an important influence on the contents of Security, both objective and subjective. It is therefore essential to bear this in mind when defining strategies and devising tools aimed at guaranteeing State security.

In this respect, changes occurring in present-day societies - changes brought about or expedited by globalization - are creating new security spaces and new models of conflict that coexist with the classic ones. This, in turn, opens new possibilities for conflict resolution and modifies the conditions and the environment in which Security Policies must be developed. ${ }^{1}$ The design and adoption of any Security Policy must be guided by the following idea: "security levels are closely related with those sectors that we want to preserve."

1 A. Recasens, La seguridad y sus políticas, SA Atelier Libros, Barcelona 2007, p. 19.

2 G. Orozco, El concepto de seguridad en la Teoría de las Relaciones Internacionales, "Revista CIDOB d'Afers Internacionals", no. 72, 2006, p. 169. 
This need for a new perspective is also evident in the European Union, common space in which internal security policies are shared, in terms of competence, by the EU and its Member States. Moreover, the crisis of refugees from Syria, Iraq and Afghanistan and the terrorist attacks in Paris in November 2015, have put the EU at the crossroads again.

In this paper, I will try to explore the different concepts of security used in history to conclude with an analysis of the European perspective in the field of European security policies.

\section{Framing a New Concept of Security}

\subsection{The Traditional Concept of Security}

For centuries, the concept of security has been settled from a national security perspective. It has largely focused on aspects closely linked to sovereignty, State borders and natural resources. In that context, security was focused on the State that had been responsible for the safeguard of its community interests. ${ }^{3}$ There was a close link between National Security and unity and territorial integrity. Unity and territorial integrity must be safeguarded, almost exclusively, through military capacity. Military advantage over foreign nations was seen as the main element of the system: ${ }^{4}$ the stronger the military power, the higher the levels of Security. In this context, two concepts set important political and strategic trends: Deterrence and Defense. From this point of view, the State main function in the security context was to defend itself and its population from foreign threats -invasions, military attacks- and internal threats - coup d'état, rebellions or national terrorism.

The First World War and, above all, the Second World War radically altered this situation. After 1945, unilateral military advantage was no longer enough to guarantee, on its own, State Security. It was necessary to forge a new concept that goes beyond the national perspective and becomes international in scope. A new idea emerged: International Security. The atrocities of the Second World War and the need for a new concept finally persuaded the Big Powers to do something new. In 1945, the United Nations Organization was created, its main purpose being the maintenance of international peace and security.

3 UNESCO, Promoting Human Security: Ethical, Normative and Educational Frameworks in Latin American and the Caribbean, available at http://unesdoc.unesco.org/ images/0013/001389/138940e.pdf, accessed 20 January $20 \overline{16 .}$

4 A. Dastis, Diccionario Lid. Diplomacia y Relaciones Internacionales, LID, Madrid 2005, p. 300 . 
The concept of International Security Concept was thereby linked to that of the International Community and to the idea of preventing a new World War. This approach guided the security system created by the United Nations Charter as reflected in its Preamble.

To achieve this aim, a system based on three fundamental principles was created: the principle of sovereign equality, the principle of non-intervention and the prohibition of threat or use of force. ${ }^{5}$

Therefore, according to this 1945 conception, International Security must be maintained through the general prohibition of the use of force and the creation of a Security system. Essentially, there were few changes apart from the notion that the military advantage must be multilateral. It was necessary to safeguard the territorial integrity and political independence of a State in its cooperation with other members of the International Community.

Within this new environment, staged by the Cold War, the maintenance of security by each State Security depended on the maintenance of the status quo, which meant the maintenance of the two "Blocs" equilibrium. As a result, all along the Cold War, the biggest threat to Security was an armed attack from States belonging to one Bloc against one State belonging to the other Bloc; the worst-case scenario was the possibility of a nuclear attack. Threats to the security of a State could materialize in armed attacks against its territory or its interests in a direct way.

\subsection{Security Now and Tomorrow}

After the fall of the Berlin Wall, this perspective has begun to change. Gradually, "the perception of an absence of direct threats, in a conventional sense, to the territory of the traditional powers has drawn attention to conflicts that did not directly affect their vital interests. Such a perception fostered the belief that armed conflict, in the form of interstate war as known from the Peace of Westphalia to the $20^{\text {th }}$ century, was a thing of the past". 6

The new scenario brought about a change in the perception of the causes of insecurity and, consequently, of the instruments to confront them. Internal conflicts have replaced the threat of direct foreign military attacks against the territorial integrity of a State. During the 90s, many internal conflicts took place in various

5 C. De Castro, El Derecho de Injerencia Humanitaria en el orden internacional contemporáneo: el Impacto de la Operación Libertad para Irak, Madrid, 2005, pp. 19-23.

6 E. Fojón, El análisis estratégico: la vuelta al pragmatismo, 18/03/2009, Real Instituto Elcano, available at www.realinstitutoelcano.org, accessed 3 November 2015. 
regions of the world and caused the destabilization of the relative peace achieved during the Cold War. It became evident that state security was to be safeguarded through lack of interstate conflicts. This idea is still embraced by many.

In this context, the concept of "New World Order", a termed that had been coined by the President of the United States of America, George Bush, in 1991. This notion was based on multilateralism and the role played by the Security Council, which was supposed to be the institution representing the International Community interests. In this manner, the Security Council became the pillar of International Security and, above all, a key actor for State Security. The new situation favors the reactivation of the Security Council, a body that, until then, had displayed few and different peace missions all around the world.

In this new "Strategic Outlook", one idea became particularly relevant: International Organizations have enough means to maintain Peace and Security and to face up to any security problem. As Fojón remarks: "what was a feature belonging to the doctrine of internationalism, or trans-nationalism, combining state action, multilateral action and cooperation to secure international peace and security, rapidly gained importance in its reductionist version: multilateralism, labelled as a strategic option, which actually ended up transformed into a panacea applied to international security." In short, the prominent role in this new scenario changes from national actors to one international actor; it is believed that trough the rule of Law a "World Government" will emerge and the Kantian dream of Perpetual Peace will ensue.

However, the NATO intervention in Kosovo had underscored the Security Council weakness, as this body had not been capable of adopting the appropriate resolutions to face up to the inevitable threat that Serbian policy posed to International Peace. Few years later, the September 11 terrorist attacks were a step further along this path, revealing the interdependence between internal and foreign threats, on the one hand, and the interdependence among all the States of the International Community when confronting this new form of threat to international security, on the other.

Thus, it is evident that we are living in convulsed times, with new "threats" and new "enemies" to fight against, and the classical concept of security, based on national security and territorial integrity ${ }^{8}$ is not fit for the current scenario; today, the security "language" must go beyond the defense of Sovereignty and States' rights. ${ }^{9}$

7 Ibid.

8 G. Orozco, G, El concepto...op.cit., p. 176.

9 J. Ortiz, La doctrina de la seguridad humana en la política exterior canadiense, "Revista Cidob D’Afers Internacionals", no. 60, 2002/2003, p. 53. 
Nor can the concept of International Security, focused as it is on a Collective Security System and on multilateral military power, provide the required perspective as the internal component must be part of the concept of security. As a result, "the military tools, traditionally means of the external dimension, will be applied in the internal area of the Security"; in the same way, "Internal Security will have a foreign dimension through civil, police and judicial instruments and in the context of international cooperation and multilateralism." In short, "the concept of security is closely linked to Peace, being largely a means to this end, so that Security implies a stable situation both from a foreign point of view and from the internal perspective of the State."10

\section{The Comprehensive Security Concept as a Premise: New models}

The changes undergone by the International Society - the end of bipolar confrontation, the outbreak of internal conflicts linked to development problems or economic stagnation or political emergencies- have entailed the superseding of the classical or traditional Security concept, as explained above. This process of evolution and "globalization" of the concept has been driven by migratory flows and international terrorist attacks. In short, today the concept of Security cannot be reductionist and State Security problems cannot be considered to derive solely from foreign attacks or internal rebellions. Far from it, Politicians and Academics consider, in the same way, that trafficking with weapons, organized crime, international terrorism, massive migrations, natural disasters, genocide, crimes against humanity, human rights violations, or the lack of development and democratic principles are some of the most important topics in the World Agenda and fall into the realm of Security. ${ }^{11}$ Therefore, a comprehensive concept of security is needed. Today, Security threats are "multiform" and come from very different actors; therefore, the instruments and policies needed to guarantee security must inevitably be global, in terms of actors and instruments alike.

Following this trend, new models have been designed that take into account all these phenomena and are linked to the globalization process. They do not focus

10 M. A. Acosta, La Política Europea de Seguridad y Defensa y la Gestión de Crisis Internacionales: Las Operaciones Petersberg, Dykinson, Madrid 2008, pp. 37-38.

11 I. Briscoe, La prevención de conflictos y la respuesta europea a los Estados en crisis, 01.03/2007 FRIDE, available a www.fride.org, accessed 18 October 2015. 
exclusively on the military or economic level, or on the national or regional ground. Rather the opposite, these fall into the expansionist Security point of view. ${ }^{12}$

One of these new tendencies in the Security context considers that States must change their points of view in Security, moving from the logic of the national thinking to the logic of global thinking; in this context, it can be said that the problems of Governments exceed national Agendas. This idea was reflected in the UN Management Fee Global Governance Report (1992-1995) that used the term "Global Security" to refer to necessities that the International Community must bear in mind to protect Peoples. Global Security must be understood as including both the traditional concept of state security and those Security of the people and the Planet. ${ }^{13}$ The challenges for Security actors in the $21^{\text {st }}$ century involve, on the one hand, protecting States against war and, on the other hand, finding new mechanisms to achieve two new objectives: a) to protect the population against internal threats of brutality and great hardship and, b) to warrant the integrity and viability of the Planet Vital Systems.

Therefore, this new concept means that the Security of the people and the Security of the Planet are to be objectives, like the Security of the States, of a new Policy for Global Security. Today we need global answers for global problems. With all these ideas, a "new thinking about Security" emerged in academic fora, in International Institutions and in national Governments ${ }^{14}$ during the eighties. All these approaches recognize that the international system has changed in a fundamental way in the last years and the need for an innovative approach to identify changes and to respond to new challenges has now become evident. It is obvious that today, in a world that is becoming increasingly globalized, the worst threats to Security come from situations that involve genocides, international terrorism, human rights violations, World epidemics, the Deterioration of the environment, Forced Labour and Modern Slavery. The idea is very clear: "the main characteristics defining the international system for over half a century were transformed by the breakdown of the bipolar order. Furthermore, changes in state capabilities and their effects on related matters such as sovereignty are

12 Ch. Abbott, P. Rogers, J. Sloboda, Respuestas globales a amenazas globales, Seguridad sostenible para el siglo XXI, FRIDE, Working Paper 27 September 2006, available a www.fride.org, accessed 1 October 2015.

13 G. Orozco, G, El concepto...op.cit., p. 173.

14 K. Pérez de Armiño, El concepto de seguridad en la Teoría de las Relaciones internacionales, "Revista CIDOB d'Afers Internacionals", no. 72, 2006, p. 62. 
having repercussions on structural aspects and on the attitudes of international actors and the way these are regarded." 15

Another factor that has contributed to this change in outlook where security is concerned is the complexity of global problems and their repercussions for millions of people. There are now threats very different from that of a military attack against one's homeland, including environmental risks, drug trafficking and terrorism. All this entails far-reaching changes in the basic idea of sovereignty and shows that national capabilities are inadequate to deal with the main problems. The new international context is changing the scale of problems that used to be wholly national in character, requiring a new international system where only the ability to pool forces will restore to states the ability to generate, jointly with other actors, a legitimate order that can satisfy the demands arising at the national, regional and world level.

To sum up, the main changes and tendencies in the international system that are influencing the way we observe and analyze the new security challenges, and that have given rise to a conceptualization which highlights the protection of individuals, are associated principally with the following structural and international factors:

- The end of the bipolar conflict with the breakdown of the Soviet Union. This removed the context within which policymaking took place for half a century.

- The impact of globalization in different areas, and interdependence. What characterized international relations was the differentiation between the national and international spheres, and this is tending to disappear with globalization.

- New international actors. New transnational actors are making a forceful appearance in the new context. Not only are multinational/transnational companies acquiring new capabilities in the conditions of globalization, but also nongovernmental organizations. The increasingly important role being played by individuals and their views in the form of global 'public opinion' is a potent factor in the new international architecture.

- New power relationships. The consolidation of the United States as a hegemonic power is translating into growing unilateralism and difficulties with multilateral policy coordination.

- New threats to security. Non-traditional security threats are appearing, most of them transnational and non-military in character. Examples include drug trafficking, money laundering and organized crime.

15 UNESCO, Promoting Human Security: ... op. cit., p. 19. 
- Development gaps. There are major difficulties in overcoming poverty and serious imbalances and inequalities in the distribution of economic resources and in national, regional and international decision-making.

- Loss of state capabilities. This factor relates to changes in sovereignty. The case of world finance most clearly illustrates states' increasing inability to control international flows.

- An increase in intra-national conflicts. Interstate conflicts are tending to diminish and internal conflicts to increase. The victims of the latter are mainly civilians.

All of these factors "design" a new scenario toward a broader concept of security whose objectives are peace, international stability and protection for individuals and communities. Since the mid-1990s we have seen the concept of human security, which emphasizes the protection of individuals, coming strongly to the fore. Before this new situation, we can see two different tendencies: on the one hand, the necessary adaptation of the international system created by the UN Charter to the new reality; on the other hand, the development of a new concept Human Security that implies the use of new mechanism to face up the threats.

\subsection{A Few Words about the Concept of Human Security}

As we have seen, the new international scenario, with a lot and different internal crises (linked, however, to human rights violations), permits the appearance of the Human Security Concept.

This concept comes from the idea that the unavoidable basis of the security is the preservation of the human being and of the necessary conditions for the free development of his capacities. From the above, it may be inferred that security shall be focused on persons and that the security of persons is threatened not only by physical violence, but also by other menaces to their survival in dignity conditions. ${ }^{16}$ It may also be inferred that the human security responses require the interaction and the feedback of other actors apart from the State, "such as NGO's, transnational corporations, public opinion (both national and international) and multilateral platforms for discussion."

In short, the Human Security concept refers to the necessity to protect the free development of persons in those countries where human rights are threatened or violated. It responds to the need to go beyond the traditional concept of National

16 K. Pérez de Armiño, El concepto de seguridad en la Teoría de las Relaciones internacionales, "Revista CIDOB d'Afers Internacionals", no. 72, 2006, p. 62. 
Security and reveals the idea according to which the aim of all institutions must be to protect human beings. In other words, the focus is shifting from the state to individuals; the fundamental issue is the protection of individuals and peoples over and above their connection with a particular state. ${ }^{17}$

Human Security has been promoted by academics, certain international organizations and even some states as a concept that would provide a better grasp of the new security challenges from the perspective of individuals or citizens. ${ }^{18}$ Furthermore, we understand that the concept of human security is a necessary input in linking security and human rights.

\subsection{The European Union and new Security Approaches}

Regional international organizations have introduced the new trends in security thought in their Security Strategies. The European Union (EU) can be counted among such regional organizations, as it has adopted policies on security that go beyond the classical concept of security and are committed to a holistic view, both domestically and internationally.

Adopting an international security perspective, the European Security Strategy (ESS) was adopted in December 2003. Its title was A Secure Europe in a better World. Sharing the new trends referred to above, this document stated that "the post-Cold War environment is one of increasingly open borders in which the internal and external aspects of security are indissolubly linked. Flows of trade and investment, the development of technology and the spread of democracy have brought freedom and prosperity to many people. Others have perceived globalization as a cause of frustration and injustice. These developments have also increased the scope for non-state groups to play a part in international affairs. And they have increased European dependence on an interconnected infrastructure in transport, energy, information and other fields. On the contrary, "in much of the developing world, poverty and disease cause untold suffering and give rise to pressing security concerns." These arguments lead to the conclusion that "Security is a precondition of development. Conflict not only destroys infrastructure, including social infrastructure; it also encourages criminality, deters investment and makes normal economic activity impossible. A number of countries and regions are caught in a cycle of conflict, insecurity and poverty." In this new environment, "large-scale aggression against any Member State is

17 S. N. MacFarlane \& Y. F. Khong, Human Security and the UN. A Critical History, Indiana University Press 2006, pp. 143-225.

18 UNESCO, Promoting Human...op.cit., p. 25. 
now improbable. Instead, Europe faces new threats which are more diverse, less visible and less predictable." These new threats are: Terrorism, Proliferation of Weapons of Mass Destruction, Regional Conflicts, State Failure and Organized Crime. Therefore, following the ESS and the documents adopted later, it is clear that, for the EU, international terrorism constitutes a threat to its external security and that, furthermore, the best way to deal with this threat is through the concept of human security in which respect and development of human rights for all are an essential element.

\subsubsection{Internal Security Strategy}

These new trends have been taken into account in the internal perspective too. In fact, the Stockholm Program "An Open and Secure Europe Serving and Protecting Citizens" (2010) adopts a comprehensive Security Concept and reiterates that "internal and external security are inseparable. Addressing threats, even far away from our continent, is essential to protecting Europe and its citizens." In this context, "the European Council emphasizes the importance of the external dimension of the Union's policy in the area of freedom, security, and justice and underlines the need for the increased integration of these policies into the general policies of the Union. The external dimension is crucial to the successful implementation of the objectives of this program and should in particular be fully coherent with all other aspects of Union foreign policy" (2010/C 115/01: 33). In essence, the aim of the Stockholm Program was to outline the political priorities of the Union's internal security. In order to establish the political priorities, the European Council considers "that the priority for the coming years will be to focus on the interests and needs of citizens. The challenge will be to ensure respect for fundamental rights and freedoms and integrity of the person while guaranteeing security in Europe. It is of paramount importance that law enforcement measures, on the one hand, and measures to safeguard individual rights, the rule of law and international protection rules, on the other, go hand in hand in the same direction and are mutually reinforced." There is a clear intention, then, to place human rights as an essential concern of the actions taken in this area.

In its Four Point, the document defines the Internal Security Strategy. In this specific context, the European Council is convinced that the enhancement of actions at the European level, combined with better coordination with actions at the regional and national level, is essential to protection from trans-national threats. Terrorism and organized crime, drug trafficking, corruption, trafficking in human beings, smuggling of persons and trafficking in arms, inter alia, continue to challenge the 
internal security of the Union. Cross-border widespread crime has become an urgent challenge that requires a clear and comprehensive response. Action of the Union will enhance the work carried out by Member States' competent authorities and will improve the outcome of their work. The European Council thus calls upon the Council and the Commission to define a comprehensive Union internal security strategy (2010/C 115/01: 17-18).

Moreover, the document The EU Internal Security Strategy in Action: five steps towards a more secure Europe (COM (2010) 673 final), adopted on November $22^{\text {nd }}, 2010$, establishes that "most Europeans are able to go about their daily lives in relative safety. At the same time, our societies are facing serious security threats that are growing in scale and sophistication. Many of today's security challenges are cross-border and cross-sectorial in nature. No single Member State is able to respond to these threats on its own. This is something that worries our citizens and businesses." The document uses a comprehensive concept of security and says that "Internal security cannot be achieved in isolation from the rest of the world, and it is therefore important to ensure coherence and complementarity between the internal and external aspects of EU security. The values and priorities in the Internal Security Strategy, including our commitment to promoting human rights, democracy, peace and stability in our neighborhood and beyond, are an integral component of the approach laid down in the European Security Strategy. As that Strategy recognizes, relationships with their partners, in particular the United States, are of fundamental importance in the fight against serious and organized crime and terrorism." And, furthermore, the document remarks that "The EU's role in our internal security consists of common policies, legislation and practical cooperation in the areas of police and judicial cooperation, border management, and crisis management. In striving to reach our security objectives, the contribution from both EU internal and external policies is crucial."

In this context, the Commission identifies the most urgent challenges to EU security and proposes five strategic objectives. The challenges are: serious organized crime, terrorism, cybercrime, border security and natural or man-made disasters. The objectives are as follows: 1) Disrupt international crime networks, 2) Prevent terrorism and address radicalism and recruitment, 3) Raise levels of security for citizens and business in cyberspace, 4) Strengthen security through border management, 5) Increase Europe's resilience to crises and disasters. Furthermore, The Commission proposes specific actions for each objective that help make Europe more secure. 
At its meeting in June 2015, the Council adopted the Renewed European Internal Security Strategy 2015-2020. ${ }^{19}$ The Strategy has identified three major priorities: fighting terrorism (with special attention to preventing radicalization, especially the issue of foreign fighters and border controls), preventing and fighting serious organized crime, as well as cybercrime. In this regard, Luxembourg Minister Nicolas Schmit, on behalf of the Presidency of the Council, has emphasized the importance of respect for fundamental rights and liberties as a "fundamental principle" in the context of the Security Strategy. He has also noted that the Strategy constitutes a "comprehensive, multidisciplinary and integrated approach based on intelligence," and that accessibility, availability and exchange of intelligence shall remain "crucial" over the coming years.

\subsubsection{European Internal Security, Immigration and Terrorism}

The creation of an area without internal borders in which citizens can move and reside freely has been improved by the Treaty of Lisbon (2007). As a consequence of the creation of a citizenship common area the need emerges to guarantee the internal security of the European Union, as a different, but not separate reality, from Member States Security. Therefore, the abolition of internal borders of states calls for the strengthening of control of the external borders and the establishment of common principles and standards for that control. As has been seen above, when establishing a common security policy, the EU identifies international terrorism as one of the greatest threats to our security.

Moreover, the establishment of an area of freedom, security and justice in the $\mathrm{EU}$, inevitably involves the creation of a common immigration policy including a common European asylum system. Therefore, from the recognition of the objective of free movement of persons in the SEA and the subsequent removal of internal borders by successive treaties reform, setting common elements for the reception of people at risk of persecution has become necessary.

The third vertex of the triangle is illegal immigration, which according to international estimates is between $10 \%$ and $15 \%$ of all international migration (CMW/C/GC/2, 28). In this scenario, Europe is a kind of El Dorado where immigrants can have access to a more dignified life, which hundreds of thousands of people try to reach at any price. This trend has increased in recent years for

19 Presidency of the Council, Luxembourg Minister Nicolas Schmit, Draft Council Conclusions on the Renewed European Union Internal Security Strategy 2015-2020, available at http://www.eu2015lu.eu/en/actualites/articlesactualite/2015/07/pe-schmit-strategiesecurite/index.htm, accessed 21 October 2015. 
various reasons including the economic crisis, armed conflicts, climate change and human rights violations in the countries of origin. These reasons are and will be the strongest factors in the increased migratory pressure (IOM 2012). The refugee crisis affecting Europe since the spring of 2015 is just a sample of this difficult reality. ${ }^{20}$ The challenge of the European Union and its Member States in this migratory pressure is, both through its policies, and its standards and, especially, their common or individual performances, to ensure the safety of individuals, and to respect and protect the human rights of irregular migrants trying to reach the European dream.

Certainly, the concern for illegal immigration in Europe is not new and already during the nineties of the last century awareness was raised on the situation of the European countries of the Mediterranean basin as recipients of migration flows from Northern Africa. However, it was not until the early $21^{\text {st }}$ century that the issue of irregular migration trying to access the EU began to be visible and disturbing, essentially for the "border-countries" like Spain and Italy. ${ }^{21}$ The turn of the screw has occurred in 2015 and 2016, when Europe has witnessed the biggest human displacement after World War II, with a daily displacement of 42.500 people fleeing mainly from war or from territories controlled by terrorist groups in unstable states. In this situation, it is crystal clear that "in an EU of 28 members, in which most of the internal borders have been abolished and people can move freely, each country alone cannot manage migration. The cooperation of the Member States of the EU is essential to better manage it; so the ISS starts from the need for specific actions to address the threat of illegal immigration must be carried out both at the EU and at the national and international levels (COM(2014) 365 final)."

In this respect, the situation of the commonly called "refugees" throughout 2015 is worsening, prompting the Juncker Commission to place immigration among one of its priorities. Thus, in May 2015 the Commission adopted the European Agenda for Migration (COM(2015) 240 final), defining four pillars for better management of migration: 1 . Reduce the incentives for irregular migration; 2. Border management: saving lives and protecting the external borders; 3 . A strong common asylum policy; 4 . A new policy on legal migration.

20 Comisión Española de Ayuda al Refugiado CEAR, Informe 2015: Las personas refugiadas en España y Europa, available at http://www.cear.es/wp-content/uploads/2015/06/ Informe-2015-de-CEAR2.pdf, accessed 6 October 2015.

21 B. Olmos, EU Return Policy and International Human Rights Law: Keeping the balance between border security and human dignity, "Spanish Yearbook of International Law" no. 18, 2014, pp. 163-164. 
This entire situation has been affected by Islamic terrorism. Terrorist attacks occurred in the early years of this century led to the adoption of the EU CounterTerrorism Strategy in 2005 (14469/4/05 REV 4). And terrorist attacks in Paris on

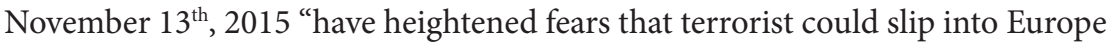
as part of an ongoing influx of migrants and refugees."22 In addition, worries persist about "homegrown" extremist inspired by Islamist propaganda to commit violence at home without traveling abroad.

\section{Conclusion}

First of all, it can be concluded that a new perception of Security has appeared in the last years, presenting some common trends: a) the interdependence of the new threats that has revealed a close link between Internal and External Security; b) the importance of multilateralism and cooperation between the different international actors as a necessary means to confront the new threats; c) the role of the people, as human well-being constitutes an essential element of the Security.

These new trends have been taken into account in the development of the EU's Security Strategies. Indeed, the terrorist attacks of September $11^{\text {th }}, 2001$ in the United States and those suffered by Spain and the United Kingdom in 2004, provided a catalyst for the culmination of the process initiated in the seventies of the last century which resulted first in the TEU through the reform made in Lisbon (2007) and, finally, in the adoption of the Stockholm Programme (2010).

The triad security/immigration/terrorism has now reached enormous significance after the terrorist attacks of $13-\mathrm{N}$ in Paris that have killed more than 120 people. After these attacks, the different positions on how to manage the refugee crisis in Europe have become more bitterly opposite. The risk of disrupting the European Area of Freedom, Security and Justice based on the rule of law and respect for human rights is shown as a possible future reality. But what is the goal of security? Does it not guarantee the enjoyment of rights and fundamental freedoms? If it does, the EU has the tools to manage, in a safe and respectful way for the rights of all citizens, the issue of legal immigrants and irregular migrants in Europe. The proper delimitation of the various regulations and, therefore, different legal regimes is a necessary step. There must be also a distinction between asylum policy and security policy. European leaders must be capable of doing it, and doing it well.

22 K, Archick, P. Belkin, European Security, Islamist Terrorism, and Returning Fighters, Homeland Security Digital Library HSDL, available at https://www.hsdl.org/? view\&did=788661, accessed 27 October 2015. 
In short, being European does not mean just raising a flag and have rights and benefits. It means sharing a project, creating spaces and common systems, and applying the values that for many years have been consolidated. Will the European Union and its Member States be capable of realizing the idea of a Europe of freedom, democracy and human rights? Will they be able to respond to the current crisis with solidarity, humanity and responsibility? Or will this new crisis make even more evident the difference of perspectives, interests and values of its member states? What impact will the revival of the terrorist threat after the terrorist attacks in Paris have on asylum policy? Does the end (of ensuring our safety) justify the means? Doesn't our security depend on the safety of others in the last resort? What about linking development/human rights/security? Again, the European project is at the crossroads; only the future will show us if it has been able to overcome this new crisis.

\section{References}

Ch. Abbott, P. Rogers, J. Sloboda, Respuestas globales a amenazas globales, Seguridad sostenible para el siglo XXI, FRIDE, Working Paper 27 September 2006, available at www.fride.org, accessed 1 October 2015.

K. Archick, P. Belkin, European Security, Islamist Terrorism, and Returning Fighters Homeland Security Digital Library HSDL, available at https://www.hsdl. org/?view\&did=788661, accessed 27 October 2015.

M. A. Acosta, La Política Europea de Seguridad y Defensa y la Gestión de Crisis Internacionales: Las Operaciones Petersberg, Dykinson, Madrid 2008.

I. Briscoe, La prevención de conflictos y la respuesta europea a los Estados en crisis, 01.03/2007 FRIDE, available at www.fride.org, accessed 18 October 2015.

CMW, General Comment No. 2 on the rights of migrant workers in an irregular situation and members of their families, UN Doc. CMW/C/GC/2, 28 August 2013.

Comisión Española de Ayuda al Refugiado CEAR, Informe 2015: Las personas refugiadas en España y Europa, available at http://www.cear.es/wp-content/ uploads/2015/06/Informe-2015-de-CEAR2.pdf, accessed 6 October 2015.

Council of the European Union, A Secure Europe in a better World. European Security Strategy, 2003.

IOM, World Migration Report 2011: Communicating Effectively about Migration.

A. Dastis, Diccionario Lid. Diplomacia y Relaciones Internacionales, LID, Madrid. 2005. 
European Commission, Communication from the Commission to the European Parliament and the Council. The final implementation report of the EU Internal Security Strategy 2010-2014, COM (2014) 365 final, Brussels, 20.6.2014.

European Commission, Communication from the Commission to the European Parliament, the Council, the European Economic and Social Committee of Regions. A European Agenda on Migration, COM (2015) 240 final, Brussels, 13.5.2015.

European Commission, Communication from the Commission to the European Parliament and the Council: The EU Internal Security Strategy in Action: Five steps towards a more secure Europe, COM (2010) 673 final, Brussels, 22.11.2010.

E. Fojón, El análisis estratégico: la vuelta al pragmatismo, 18/03/2009, Real Instituto Elcano, available at www.realinstitutoelcano.org, accessed 3 November 2015.

S. N. MacFarlane, Y. F. Khong, Human Security and the UN. A Critical History, Indiana University Press 2006.

B. Olmos, EU Return Policy and International Human Rights Law: Keeping the balance between border security and human dignity, "Spanish Yearbook of International Law" no. 18, 2014.

G. Orozco, El concepto de seguridad en la Teoría de las Relaciones internacionales, "Revista CIDOB d'Afers Internacionals", no. 72, 2006.

J. Ortiz, La doctrina de la seguridad humana en la política exterior canadiense, "Revista Cidob D’Afers Internacionals", no. 60, 2002/2003.

K. Pérez de Armiño, El concepto de seguridad en la Teoría de las Relaciones internacionales, "Revista CIDOB d'Afers Internacionals", no. 72, 2006.

A. Recasens, La seguridad y sus políticas, SA Atelier Libros, Barcelona 2007.

Presidency of the Council, Luxembourg Minister Nicolas Schmit, Draft Council Conclusions on the Renewed European Union Internal Security Strategy 2015-2020 available at http://www.eu2015lu.eu/en/actualites/articlesactualite/2015/07/pe-schmit-strategie-securite/index.htm, accessed 21 October 2015.

UNESCO, Promoting Human Security: Ethical, Normative and Educational Frameworks in Latin American and the Caribbean, 2005, available at http://unesdoc. unesco.org/images/0013/001389/138940e.pdf, accessed 19 November 2008. 


\section{Legal Instruments and Specific Actions in the EU's Fight against Terrorism}

\section{Introduction}

Terrorism is one of the key global challenges and one of the priorities of the European Union. It poses a threat to our security, to the values of our democratic societies and to the rights and freedoms of European citizens. Terrorism is not a new phenomenon in Europe, but recent developments impose new perspectives on it.

In this paper, I shall present an overview of how the EU institutions, in close cooperation with the Member States and other international organizations, have tried to fight this phenomenon and to grant protection to citizens potentially affected by the activity of terrorist groups.

\section{Definitions}

Before entering the topic, the author considers it appropriate to review some definitions contained in the various legal instruments adopted in the field. Among the notions found in the acts adopted by the European Union, I choose those in the Common Position 2001/931. ${ }^{1}$ I believe that, although this legal instrument has more than a decade, the definitions may trace back essentially to current situations. $^{2}$

Under this act, for the purposes of this Common Position, ${ }^{3}$ persons, groups and entities involved in terrorist acts ${ }^{4}$ shall mean: a) persons who commit, or attempt to commit, terrorist acts or who participate in, or facilitate, the commission of

1 Council Common Position of 27 December 2001 on the application of specific measures to combat terrorism (2001/931/CFSP), available at http://eur-lex.europa.eu/legalcontent/EN/TXT/?uri=CELEX\%3A32001E0931, accessed 2 February 2016.

2 The list of persons and entities referred to in the Annexes to this act has been to be, however, completed and updated in subsequent legal actions.

3 Although this act, in principle, limits, the concept to its scope of application, I believe that we can take it as a reference definition.

4 A. Asúa, Concepto jurídico de terrorismo y elementos subjetivos, in: Estudios Jurídicos en memoria de José María Lidón J. I. Echano Basaldua (ed.), Universidad de Deusto, Deusto 2002, p. 62. 
terrorist acts; b) groups and entities owned or controlled directly or indirectly by such persons; and c) persons, groups and entities acting on behalf of, or under the direction of, such persons, groups and entities, including funds derived or generated from properties owned or controlled directly or indirectly by such persons and associated persons, groups and entities.

For the definition of terrorism, ${ }^{5}$ we choose the one contained in the Council Framework Decision ${ }^{6}$ of June $13^{\text {th }}, 2002$ on combating terrorism. The mere threat ${ }^{7}$ of committing such an offense should be considered a terrorist act.

\section{Action Programs of the European Union in the Fight against Terrorism}

The attacks in Madrid (2004) and London (2005), the frustrated attempts in the summer 2006 in Germany, the UK and Denmark, and the failed attacks in London and Glasgow in 2007, showed that the territory of the European Union is a target for global terrorism linked to Islamic-inspired groups. The European Union and the Member States are committed to jointly fighting terrorism and providing for the best possible protection for citizens. To that end, in 2005 the Council ${ }^{8}$ adopted the EU counter-terrorism strategy, ${ }^{9}$ which has provided the framework for the European Union's activity in this field. This legal instrument aims to combat terrorism globally, while respecting human rights, to make Europe safer, and

5 J. Alcaide, Las actividades terroristas ante el Derecho Internacional Contemporáneo, Tecnos, Madrid 2000.

H. P. Gasser, Actos de Terror, Terrorismo y Derecho Internacional Humanitario, "Revista Internacional de la Cruz Roja”, Boletín del Instituto Español de Estudios Estratégicos 2002.

C. Swinarski, Del terrorismo en Derecho Internacional Público, Derecho Internacional Humanitario y temas de áreas vinculadas, Lexis, Buenos Aires 2003.

6 Council Framework Decision of 13 June 2002 on combating terrorism (2002/475/ JHA), available at http://eur-lex.europa.eu/legal-content/EN/TXT/?uri=CELEX\% 3A32002F04759, accessed 1 February 2016.

7 This clarification appears in all acts and strategies. This implies that all notions related to terrorism must be interpreted extensively.

8 Among the Institutions, the Council and the European Council have led the way in boosting Strategies and other activities but, as will be seen below, the other institutions have also made significant contributions to the fight against terrorism.

9 EU Counter-Terrorism Strategy, 14467/Brussels, 30 November 2005, available at http://eur-lex.europa.eu/legal-content/EN/TXT/?uri=URISERV\%3Al33275, accessed 1 February 2016. 
to allow its citizens to live in an area of freedom, security and justice. It promotes democracy, dialogue and good governance to tackle the causes of radicalization. ${ }^{10}$

The European Union is, as it is recognized in this act, an area of increasing openness, in which internal and external aspects of security are intimately linked. It is an area of increasing interdependence, allowing for free movement of people, ideas, technology and resources. This is an environment which terrorist abuse to pursue their objectives. ${ }^{11}$

In this context, concerted and collective European action, in the spirit of solidarity, is indispensable to combat terrorism. This strategy is focused on four main actions: prevent, protect, pursue and respond. ${ }^{12}$ Across these actions, the strategy recognizes the importance of cooperation with third countries and international institutions. In fact, across the measures adopted, a horizontal feature is the European Union's role in the world. Through its external action, the European Union takes on a responsibility for contributing to global security. Acting through and in conjunction with other international organizations, the European Union will work to build the international consensus and promote international standards for countering terrorism.

The European Union is aware that terrorism remains a threat to the political foundations of the European Union as well to life and well-beings of citizens, then, political oversight of this Strategy and regular follow-up will be essential. Following this idea, contained in the Strategy itself, the European Council adopted in 2007 the so-called EU Action Plan on Combating Terrorism (2007). ${ }^{13}$ This legal instrument does not contain any relevant developments regarding the strategy.

By contrast, the EU Action Plan on Combating Terrorism (2011), ${ }^{14}$ which revises the previous one, has a greater interest. This legal instrument is linked to the question of potential risk that the phenomenon of foreign fighters poses to

10 These ideas are the leitmotif of all EU actions against terrorism.

11 F. Ruiz, La estrategia de la Unión Europea contra el yihadismo en tiempos de ISIS, "Boletín del Instituto Español de Estudios Estratégicos” no. 17, 2015, p. 4.

12 I will follow this structure for presenting the panorama of events, actions and activities of the EU in this area.

13 EU Action Plan on Combating Terrorism. Brussels, 2007, available at http://eur-lex. europa.eu/legal-content/EN/TXT/?uri=URISERV\%3Al33275, accessed 1 February 2016.

14 EU Action Plan on Combating Terrorism, Brussels, 2011, available at http://register. consilium.europa.eu/doc/srv?l=EN\&f=ST\%2015893\%202010\%20REV\%201, accessed 1 February 2016. 
the European Union. ${ }^{15}$ It also includes a section called International Cooperation, where the European Institutions express their will to expand the strategic relations of the European Union in the fight against terrorism. ${ }^{16}$

\section{Concrete Action Lines}

\subsection{Prevent}

The historical characteristics of Europe's counter-terrorism approach have been: first, to treat terrorism as a crime to be tackled through criminal law; and second, to emphasize the need for understanding the root causes of terrorism in order to be able to prevent terrorist acts. This idea underlies the acts of the EU institutions in recent years.

One of the EU's priorities in the field of counter-terrorism is to identify and tackle the factors which contribute to radicalization and the processes by which individuals are recruited to commit acts of terror. Preventive measures aim, then, at combating radicalization and terrorist recruitment, identifying the methods, propaganda and tools used by terrorists. ${ }^{17}$ Although these challenges depend on the Member States, the EU helps to coordinate national policies, identify good practices and exchange information.

Key priorities for the prevention are: to develop common approaches to spot and tackle problematic behavior, in particular, the misuse of the Internet; to address incitement and recruitment, particularly in crucial environments, for example, places of religious training or worship; to develop a media and communication strategy in order to explain better the European Union's policies ${ }^{18}{ }^{10}$ to promote good governance, democracy, education and economic prosperity through Community and Member States assistance programs; to develop inter-cultural dialogue within and outside the European Union; to develop a non-emotive lexicon for discussing the issues; to continue research, share analysis and experiences in order to further our understanding of the issues and develop policy responses.

15 The European Union is concerned, to a great extent, about the phenomenon of fighters from Europe traveling to different places to join the jihad and the threat they pose to security within the EU on their return. This idea appears in the actions and strategies of recent years.

16 We have already seen that this idea appears in all instruments, but it is the first time it is recognized as a separate item.

17 G. Díaz, P. Rodríguez, La UE y el terrorismo islamista, “UNISCI Journal”, no. 39, 2015, p. 180.

18 This has been developed in particular, as discussed below. 
These are the measures proposed in the EU 2005 Strategy of the European Union to combat terrorism. In furtherance of these points, the Council adopted, in turn, the EU's strategy for combating radicalization and recruitment to terrorism. Even before the development of this strategy, the EU had worked to try to prevent, as far as possible, the actions of terrorists. I wish to refer to them, before presenting the 2005 Strategy and the revised 2014 Strategy, in order to be able to assess all European actions in this field. ${ }^{19}$

Among them, I would like to highlight the common positions $2001 / 930^{20}$ and 2001/931 PESC. ${ }^{21}$ In the first one, crime of financing terrorism, refusal to shelter suspects, measures to prevent recruitment into terrorist groups and to prevent the supply of weapons are contemplated.

The second position encompasses a list of persons, groups and entities involved in terrorist acts to which the measures to freeze funds and other financial assets or economic resources involved in terrorist acts. Therein lies, in my opinion, much of the value of this event, ${ }^{22}$ especially for the practical approach.

Moreover, these instruments are the result of the necessary cooperation between International Organizations. In fact, their adoption reflects the desire of the EU to implement Resolution 1373 of the United Nations Security Council. ${ }^{23}$ Also the fight against the financing of terrorist activities had already been approached. The Council Regulation (EC) No 2580/2001 of December $27^{\text {th }}, 2001,{ }^{24}$ concerning specific restrictive measures directed against certain persons and entities with a view of combating terrorism, aims to prevent and prohibit the financing of terrorist acts, that is to say, intentional offenses which, by their nature or context, may

19 J.R. de Prada Solaesa, Terrorismo: Convenios Sectoriales. Financiación y Blanqueo, Consejo General del Poder Judicial 2013.

20 Council Common Position of 27 December 2001 on combating terrorism, available at http://eur-lex.europa.eu/LexUriServ/LexUriServ.do?uri=OJ:L:2001:344:0090:0092:EN: PDF, accessed 1 February 2016.

21 Council Common Position of 27 December 2001 on combating terrorism, available at http://eur-lex.europa.eu/LexUriServ/LexUriServ.do?uri=OJ:L:2001:344:0093:0096: EN:PDF, accessed 1 February 2016.

22 Also of great use is the insertion of the glossary on terrorists and terrorist acts, as we have seen in the definitions section.

23 Resolution 1373 of the Security Council of the UN, 2001, available at http://www. un.org/en/sc/ctc/specialmeetings/2012/docs/United\%20Nations\%20Security\%20 Council\%20Resolution\%201373\%20(2001).pdf, accessed 1 February 2016.

24 Council Regulation (EC) No 2580, 2001, available at http://eur-lex.europa.eu/LexUri Serv/LexUriServ.do?uri=OJ:L:2001:344:0070:0075:EN:PDF, accessed 1 February 2016. 
damage a country when committed with the intention of seriously intimidating the population, destabilizing the country, etc.

In December 2005, the Council adopted the European Union Strategy for Combating Radicalization and Recruitment to Terrorism. The Strategy sets out three general strands for the EU's action: to disrupt the activities of networks and individuals who draw people into terrorism, to ensure that voices of mainstream opinion prevail over those of extremism and to promote - yet more vigorously security, justice, democracy and opportunity for all. The Strategy and the accompanying classified Action Plan contain both joint standards and new measures. While recognizing the primacy of the Member States in the field of radicalization and recruitment, the Strategy proposes a set of specific measures to be implemented at the European level. These measures cover all three pillars and require close co-operation between the Council and the Commission.

The Action Plan on Combating Radicalization and Recruitment adopted in 2005 instructed the Council, in consultation with the Commission, to draw up a communication strategy with the purpose of combating radicalization and recruitment to terrorism through effective communication of the EU's values and policies in the media. On this basis, the Media Communication Strategy was developed and adopted by the Council in July 2006, consisting of three main parts: 1) key messages on counter-terrorism; 2) suggestions on how to deliver the key messages to various audiences; 3 ) a common lexicon which has been expanded over time. The strategy is designed to use communication of the EU's values and policies to prevent terrorism. However, it is not exclusively concerned with communication on counter-terrorism. It should be used in the context of the EU's communication on a range of topics that may have a bearing on processes of radicalization, such as integration, human rights, the rule of law, development assistance, etc.

The Counter-Terrorism Coordinator updates the Strategy and the Action Plan for Combating Radicalization and Recruitment to Terrorism on yearly basis. Thus, in 2014 the Strategy is revised to accommodate the new risk factors that were detected in the successive international events affecting the Member States. Of particular concern is the phenomenon of terrorists or lone fighters, and recently, the growing potential of social networks for mobilization and communication. Taking into account these factors, the Council proposes the following measures: to promote security, justice, and equal opportunities for all; to ensure that voices of mainstream opinion prevail over those of extremism; enhance government communications; to support messages countering terrorism; counter online radicalization and recruitment to terrorism; to train, build capacity and engage first line practitioners across relevant sectors; support individuals and civil society to 
build resilience; to support disengagement initiatives; to support further research into the trends and challenges of radicalization and recruitment to terrorism; to align internal and external counter-radicalization work.

In December 2014, the Ministers of Justice and Home Affairs adopted a series of conclusions regarding the revised strategy. These guidelines set out a series of measures to be implemented by the EU and the Member States..$^{25}$ They would contribute to the criminal justice response to radicalization leading to terrorism and violent extremism. As particular actions, these documents include measures in relation to the Structure and organization of detention regimes, alternative or additional measures of prosecution and/or detention, integration, rehabilitation and re-integration, training and learning from monitoring and exchange of practices.

\subsection{Protect}

The second priority of the EU's counter-terrorism strategy is the protection of citizens and infrastructure, as well as the reduction of vulnerability to attack. This includes the protection of external borders, the improvement of transport security, the protection of strategic targets and the reduction of the vulnerability of critical infrastructure.

In particular, in European Union Strategy includes, as specific measures: to deliver improvements to the security of European Union passports through the introduction of biometrics; to establish the Visa Information System and the second generation Schengen Information System; to develop through Frontex an effective risk analysis of the European Union's external border; to implement agreed common standards on civil aviation, port and maritime security; to develop a European program for critical infrastructure protection; to make best use of European Union and Community level research activity.

In the action plan on combating terrorism (2007), and especially in the Action Plan on Combating Terrorism (2011), these measures are developed, and new measures are incorporated, in relation to the Cyber Security ${ }^{26}$ and the security of explosives. ${ }^{27}$

25 These Conclusions underline the essential role of the local actors. This is, in my opinion, an added value of this document.

26 The document underlines the increasing dependency of our society on the internet and IT infrastructures, and reminds that the issue of Cyber Security is an area of growing concern for state and non state actors.

27 The use explosives remains the main threat when it comes to possible terrorist modus operandi within the EU. 


\subsection{Pursue}

The EU is working to hinder terrorists' planing and organizational capacities, and to bring these terrorists to Justice. To achieve these goals, the EU has focused on strengthening national capabilities, improving practical cooperation and information exchange between police and judicial authorities (in particular, through Europol and Eurojust), tackling terrorist financing and depriving terrorists of the means by which they mount attacks and communicate. ${ }^{28}$

In particular, the 2005 Strategy includes, as its key priorities: strengthening national capabilities to combat terrorism; making full use of Europol and Eurojust to facilitate police and judicial cooperation; inducing a further development of mutual recognition of judicial decisions and adopting the European Evidence Warrant; ensuring full implementation and evaluation of existing legislation as well as the ratification of relevant international Treaties, and developing the principle of availability of information possessed by law enforcement agents.

The Action Plan on Combating Terrorism (2011) stresses the need to continue and increase the efforts to uncover terrorist networks, to impede communication, travel and planning activities of terrorists and their supporters; to cut off funding and access to attack materials, and to file them in court. This document includes measures in relation to data sharing, ${ }^{29}$ Passenger Name Records as a key element in the fight against international terrorism, and the need of approximation of Member States' criminal law and mutual recognition. ${ }^{30}$

\subsection{Respond}

This objective of the EU's counter-terrorism strategy is to prepare (in the spirit of solidarity), to manage and to minimize the consequences of a terrorist attack. This is done by improving capabilities of dealing with the aftermath, the coordination of the response, and the needs of victims. Priorities in this area include the

28 In some documents, the EU itself introduces into the measures of persecution, the already mentioned measures against money laundering and financing of terrorism. In order to structure my presentation, I prefer to add them to the prevention, since I believe, as I have already noted, that the basis for them is to attack structural problems related to terrorism.

29 This includes the exchange of Passenger Name Records, the processing and transfer of Financial Messaging Data and the exchange of data within the Schengen area.

30 The recommendations centre around the following themes: judicial organization, special investigation techniques and terrorist financing, rights of defense, judicial cooperation, international perspective, strategy for EU prosecutions and criminal policy. 
development of the EU's crisis co-ordination arrangements, the revision of the civil protection mechanism, the development of risk assessment and the sharing of best practices in terms of assistance to victims of terrorism.

In relation to the civil protection mechanisms ${ }^{31}$ the main instruments for reaching these objectives are Council Decision 2007/162/EC, Euratom of March $5^{\text {th }}, 2007$ establishing a Civil Protection Financial Instrument ${ }^{32}$ and Council Decision 2007/779/EC/Euratom of 8 November 2007 establishing a Community Civil Protection Mechanism (recast). ${ }^{33}$ Both are major elements in the Protect and Respond chapters of the EU Counter-Terrorism Strategy.

The solidarity in the protection of victims of terrorism remains a major concern for European Institutions. The Action Plan on Combating Terrorism (2011) underlines that assistance and compensation to the victims of terrorism has to remain an integral part of the EU's policy. The Member States and the Commission shall continue their work and assistance to victims and organizations representing victims of terrorism.

\section{The Counter-Terrorism Coordinator}

Following the terrorist attacks in Madrid on March $11^{\text {th }}, 2004$, the European Council adopted a declaration on combating terrorism. Among the measures included in this declaration was the establishment of the position of a CounterTerrorism Coordinator. His/her task, which includes 6-monthly reports on the implementation of the various Strategies, can be summarized as follows: coordinating the work of the Council in combating terrorism; presenting policy recommendations and proposing priority areas for action to the Council; closely monitoring the implementation of the EU's counter-terrorism strategy; maintaining an overview of all the instruments at the European Union's disposal; reporting to the Council and following up Council decisions effectively; coordinating his/ her actions with the relevant preparatory bodies of the Council, the Commission and the EEAS, and sharing information with them; making sure that the EU plays an active role in the fight against terrorism; improving communication between the EU and third countries in this area. In fulfilling this mandate, the main task of the coordinator is the collaboration in reviewing different strategies. This work,

31 In my opinion, this is the most useful aspect in response measures.

32 Council Decision of 5 March 2007, available at http://eur-lex.europa.eu/legal-content/ EN/TXT/?uri=CELEX\%3A32007D0162, accessed 1 February 2016.

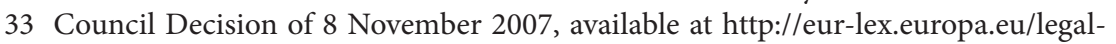
content/EN/ALL/?uri=CELEX:32007D0779(01), accessed 1 February 2016. 
as we have seen, is critical because, as recalled in all instruments, strategies shall constantly be revised and adapted.

\section{Specific Strategies to Fight against the Islamic State}

In the Outline of the counter-terrorism strategy for Syria and Iraq, with particular focus on foreign fighters, ${ }^{34}$ the European Union redirects the four points (prevent, protect, pursue and respond) to this specific scope. ${ }^{35}$ Regarding the prevention, the European Union needs to be sensitive to the differing motivations for travel. The European Union should also work with the third countries that are significant source of foreign fighters, particularly the Maghreb, or transit countries. In particular, the Union should aim to provide alternative non-violent outlets, such as diversionary activity for those who are attracted to the Syrian and Iraqi conflicts.

Regarding the question of pursuit, the European Union should work with the third countries to improve operational co-operation in order to identify and dismantle recruitment and facilitation networks, as well as to identify and prosecute foreign fighters. Given the role of kidnapping for ransom in raising funds for ISIL/Daesh, the European Union should promote its position on this issue and raise awareness of the risks (in particular, in the private and non-governmental sectors). The European Union should consider undertaking appropriate actions to strengthen border security (including at airports and other border-crossing points) in countries surrounding Syria and Iraq in order to help detect and complicate travel and identify quickly those who may pose a threat. In addition, the Union should work to better understand how terrorist groups in Syria and Iraq are acquiring their weapons and equipment, and act to prevent weapons proliferation (both into, and out of, Syria and Iraq).

In the field of protection, building capacity regarding aviation security regionally should also be a priority. Containing the threat within the Syrian and Iraqi borders must also include actions aimed to prevent advanced conventional weapons or weapons-technology from seeping out. Finally, regarding the question of responding, the Union should build capacity in the region to respond to terrorist attacks. This should include helping to empower civil society, including developing crisis management tools, to enable them to respond to attacks that target their communities.

34 Council Regulation (EC) No. 11570, 2015, available at http://europeanmemoranda. cabinetoffice.gov.uk/files/2015/09/11570-15.pdf, accessed 1 February 2016.

35 We present the most striking developments of these points included in this strategy. 
The Annual Report 2015 to the European Parliament by the High Representative of the Union for Foreign Affairs and Security Policy suggests some guidelines to follow, to deal with the terrorist threat posed by the ISIS. The document supports the global coalition against the Islamic State and its efforts to fight militarily against it. Federica Mogherini's document also stresses the urgent need to counter the use of the Internet by jihadi groups for recruitment and propaganda. Finally, she insists on the need to increase international cooperation and cooperation within the EU, designed to prevent extremists from traveling to Syria and Iraq to join the jihadist fight.

As to the recent initiatives to combat terrorism in general, in their Statement on counter-terrorism of February $12^{\text {th }}, 2015{ }^{36}$ the members of the European Council set out an ambitious agenda based on three pillars: ensuring the security of citizens; preventing radicalization and safeguarding values; cooperating with our international partners.

\section{Conclusion}

The EU's institutions have reacted to new international events, and this, in itself, should be considered a positive development. It is an entirely different matter whether such reaction, and that of Member States, has been effective. It largely depends on how Member States are implementing the relevant anti-terrorism policy. Terrorist groups are capable of reinventing themselves on a daily basis.

One of the weak points of the strategy to counter terrorism is, in my view, the protection of the victims. The instruments studied in this work express much concern for victims but lack specific measures to address their needs and the challenges posed by their protection. The EU and its Member States must face these issues as soon as possible if victims are to enjoy adequate protection.

In all legal instruments, especially the most recent, a great concern for the issue of foreign fighters is detected. However, other measures which, in my opinion, are of vital importance - such as those related to the control of exports in order to prevent terrorists to divert, so that terrorists can divert weapons, goods or dualuse technologies - are missing.

Another striking fact detected in this work is that although there are rules and policies designed to prevent the funding of terrorist activities and to establish lists

36 Informal meeting of the Heads of State or Government, Brussels, Statement by the members of the European Council, 2015, available at http://www.consilium.europa.eu/ en/press/press-releases/2015/02/150212-european-council-statement-fight-againstterrorism/, accessed 1 February 2016. 
of individuals and groups involved in terrorism, rules governing the exchange of information are scarcer, even though the need for such rules is a pressing one.

Cooperation with the third countries and international organizations is intense in the field of prevention. This is evidenced by the agreements with the United States and the accession of the European Union and the Member States to international instruments, such as those related to weapons of mass destruction. The relation between the EU and the UN revolves around two different issues: an acceptance of a series of principles, notions and standards adopted in both organizations, on the one hand, and an active promotion of the EU and the UN's policies, with a view of developing a global strategy.

\section{References}

J. Alcaide, Las actividades terroristas ante el Derecho Internacional Contemporáneo, Tecnos, Madrid 2000.

A. Asúa, Concepto jurídico de terrorismo y elementos subjetivos, en Estudios Jurídicos en memoria de José María Lidón, J. I. Echano Basaldua (ed.), Universidad de Deusto, Deusto 2002.

Council Common Position of 27 December 2001 on the application of specific measures to combat terrorism ((2001/931/CFSP), available at http://eur-lex.europa.eu/legal-content/EN/TXT/?uri=CELEX\%3A32001E0931, accessed 2 February 2016.

Council Framework Decision of 13 June 2002 on combating terrorism (2002/475/ JHA), available at http://eur-lex.europa.eu/legal-content/EN/TXT/?uri= CELEX\%3A32002F04759, accessed 1 February 2016.

Council Regulation (EC) No 2580(2001) 27 December 2001, available at http:// eurlex.europa.eu/LexUriServ/LexUriServ.do?uri=OJ:L:2001:344:0070:0075, accessed 1 February 2016.

J. R. de Prada Solaesa, Terrorismo: Convenios Sectoriales. Financiación y Blanqueo, Consejo General del Poder Judicial, España 2013.

G. Díaz, P. Rodríguez, La UE y el terrorismo islamista, "UNISCI Journal”, no. 39, 2015.

EU Action Plan on Combating Terrorism. Brussels, 2007, available at http://eurlex.europa.eu/legal-content/EN/TXT/?uri=URISERV\%3Al33275, accessed 1 February 2016.

H. P. Gasser, Actos de Terror, Terrorismo y Derecho Internacional Humanitario, "Revista Internacional de la Cruz Roja", Boletín del Instituto Español de Estudios Estratégicos 2002. 
C. Swinarski, Del terrorismo en Derecho Internacional Público, Derecho Internacional Humanitario y temas de áreas vinculadas, Lexis, Buenos Aires 2003.

F. Ruiz, La estrategia de la Unión Europea contra el yihadismo en tiempos de ISIS, "Boletín del Instituto Español de Estudios Estratégicos" no. 17, 2015. 

Juan Manuel Goig Martínez and María Acracia Núñez Martínez

\section{The Islamic State's Political Organization. The Political Impact of Jihadist Terrorrism: Consequences in the European Union}

\section{Introduction: The Arab Spring}

The "Arab Spring" is the name given by the media to a series of popular and political demonstrations that took place in the Arab region starting at the beginning of 2011. Most of them were a consequence of the extremely grave economic and financial situation in the region, and of the absence of political freedom that precipitated the government breakdown in Tunisia, Egypt and Libya, and caused instability in Yemen, Bahrain, Iraq and Syria.

These revolts have no precedent in the Arab world. In fact, in their history there have been many secular and republican revolutions, but all of them were born from military coup d'états and gave birth to new, often authoritarian governments, supported or not by the civilians. The difference in the present situation is the claim of democracy and the substantial improvement of living conditions. Given the nature of their claims - democratic freedom, political and social change some European observers associate them with the European revolutions of 1830, 1848 and 1989 in East Europe, after the fall of the Berlin Wall. ${ }^{1}$

The third democratic wave, from the mid-seventies to the nineties of the $20^{\text {th }}$ century in the southern and eastern Europe, Latin America and Asia-Pacific, had not run through the frontiers of North Africa and the Middle East. The Arab world became the exception. That is the reason why revolts were received with optimism by those who believe that democratic transitions are produced in phases and affect simultaneously several countries in the same region.

\subsection{Causes}

The Arab Spring was a popular reaction against the ongoing abuses perpetrated by authoritarian regimes. In spite of the existing differences between Arab countries, most of them are characterized by a lack of political freedoms; a systematic

1 S. Mangana, Las protestas en los países árabes son en respuesta al inmovilismo político, "Vadenuevo" no. 31, Montevideo 2011, available at https://www.vadenuevo.com.uy/ index.php/faq/105-entrevistas/2064-31vadenuevo01, accessed 20 January 2016. 
violation of human rights; restrictive legislation; evident gender inequality (being a result of the religious context, but also of the patriarchal values prevailing); and emerging laws created under the pretext of fighting external threats, as in the cases of Egypt, Algeria, Syria and Saudi Arabia.

The most neutral analysts believe that the causes of the initial demonstrations were the consequences of the economic crisis in a region that had put all its economical expectations on petrol. Those specialists, who are more aligned with the movement, describe the "Spring" as the product of the social maturity in societies which fight against inequality and search for people's higher participation in political decisions.

The popular uprisings took place as a consequence of several structural causes: corruption, inefficiency and repressive eagerness of the regimes in the area. The permanent dissatisfaction in terms of basic needs from a wide percentage of the population - mostly young and with no expectation of developing a dignified life - is a structural component of a situation which explains the present mobilizations. ${ }^{2}$

We can differentiate various factors explaining the emergence of these revolutionary movements: ${ }^{3}$

- Historical: the loss of three wars against the State of Israel, that forced some countries in the region to accept peace and cooperation agreements with the United States, thanks to which the United States acquired control of the petrol resources and at the same time committed to maintain despotic leading figures in power, such as Mubarak in Egypt.

- Political: the establishment of single party dictatorships, which silenced the population.

- Economic: the 2008 Wall Street financial crisis obliged many countries to adopt unpopular financial measures.

- Social: the existence of a very young population with high unemployment rates and the impossibility of immigrating to Europe, given the obstacles imposed by European countries.

2 J. Núñez, Apuntes de urgencia sobre la oleada de cambios en el Mundo Árabe, Instituto de Estudios sobre Conflictos y Acción Humanitaria (IECAH), Fundación Carolina, no. 18,2011 , pp. 39-43.

3 I. Ramonet, Cinco causas de la insurrección árabe, "Le Monde Diplomatique" 05.03.2011, available at http://www.monde-diplomatique.es/?url=editorial/0000856412872168186811102294251000/editorial/?articulo $=8 \mathrm{ca} 803 \mathrm{e} 0$ 5eba-4c95-908f-64a36ee042fd, accessed 20 January 2016. 


\subsection{Consequences}

The consequences of the Arab Spring movements and revolts have been many and of a very different nature. The governments that have collapsed or been brought down had a model which was similar to the Soviet style countries, with a single party that was maintained by powerful security structures. The Arab monarchies have stood better than other systems in the area (Jordan, Morocco and the Persian Gulf); perhaps they guessed that establishing changes, even small changes with almost no repercussions, would be an important step for avoiding popular revolts. Another important consequence is the need for the United States to change their foreign politics in the Middle East, and the map secretly drawn by the UK and France during the First World War is apparently disappearing. ${ }^{4}$ The deep social and political transformations in the Arab world, the emergence of the general populace as an important political actor, the simultaneous demands placed on the authorities for accountability; and the increasing public debates about these Arab societies' futures, which were exposed as the main consequences of the movement, have not been completely resolved.

Four years after the Arab Spring, we do not have many reasons for optimism. In Egypt, a general reduction of freedoms has taken place since el-Sisi arrived in power. The Muslim Brotherhood, the winning party in the legislative elections of 2011 and in the presidential elections of 2012, have been removed from power and banned, accused of being a terrorist group. An anti-protest law has been approved to prevent large demonstrations such as those in Tahrir Square. Also, various activists have been condemned to long prison sentences for questioning that law. The Social Affairs and Justice Ministry has given an ultimatum to all the associations registering under the very restrictive law of $84 / 2002$, allowing the authorities to dissolve associations, block their funds and even put their leaders in prison, if they are a threat to national security. ${ }^{5}$

In the case of Syria and Iraq, we encounter two sectarian regimes trying to exploit religious heterogeneity to their own benefit. The civil conflict in both countries has caused many non-state groups to challenge the legitimate monopoly of the use of violence by the central power. Armed militia and jihadist groups have empowered themselves by taking control of significant areas of territory, which

4 VVAA., La Primavera Árabe y sus consecuencias, "Journal Alif”, no. 98, 2011.

5 T. Cartalucci, 2011: Year of the dupe 2011, Land Destroyer Report, available at http:// landdestroyer.blogspot.com/2011/12/2011-year-of-dupe.html, accessed 1 December 2015. 
in some regions implied a retrograde interpretation of Islamic law or Sharia and, in some cases, the persecution of religious minorities.

Yemen and Libya, where the former leaders were kicked out of power, have now embarked on a dangerous "journey to nowhere" as a result of the central power's breaking down.

Faced with the social changes in the North of Africa and the Middle East, several analysts have defended the birth of a new "democratization wave." However, we cannot refer to it as a "democratization wave", but we should rather describe them as a "wave of political change", within a certain region, with very different effects depending on the nature of the Arab regimes. Of all the democratic transitions, which were opened in 2011, the only democratic regime has been established in Tunisia. ${ }^{6}$ Other Arab countries have undertaken political liberalization processes, which have not caused substantial changes in the authoritarian nature of power. ${ }^{7}$

In Tunisia, the democratic transition continues forward, in spite of the political clashes, the social gaps, the economic crisis, the regional instability and the terrorist threat. However, it may end up being unviable if the current regional situation carries on, not only because of the jihadist threat inside and outside its borders but also because their history has proven the structural dependence of Arab societies on each other.

Will the societies, in which this movement was born, fight for their citizenship, for viable civil societies, for democratic and transparent political institutions? It is unlikely that social movements can survive if local institutions and social groups are not flexible. Democratic development depends on the consolidation of a middle class - a social class generally not present in the region, with the exception of Turkey. ${ }^{8}$ A strong, independent civil society is vital, as democratization processes depend on it.

Another important consequence is the deepening schism between the two branches of Islam, which has led to alarming levels of sectarian violence. And, certainly, the most important reason has been the increase of regional instability after the beginning of the struggle for power in the majority of the affected countries.

The irruption of the Islamic State (IS) means a new destabilizing factor. The above-mentioned group, which controls several Syrian and Iraqi provinces and

6 P. Morillas, Lo que queda de la primavera árabe, cuatro años después, "Política Exterior" no. 163, 2015.

7 VVAA., Escenarios post-Primavera Árabe: actores y dinámicas de cambio, "Journal CIDOB d'Afers Internacionals", no. 109, 2015.

8 B.S. Turner, La ciudadanía árabe: la Primavera Árabe y sus consecuencias no intencionales, "Sociología Histórica" no. 1, 2012. 
governs over millions of people, is trying to restore an Islamic caliphate. Their practices include flagellations, amputations, crucifixions, torture and summary executions, and they are not only applied to their enemies, but also to those who drink alcohol, commit adultery or steal. The Islamic State has brought into the spotlight the treatment of minorities, together with deportations of Christians and the elimination of the Yazidis, including Muslims themselves, as they call Shia apostates, and of all those who dare to question their fanatical interpretation of Islam. In this respect, it is worth remembering that massacres have been perpetrated in recent months between various Sunni groups that rose against them and various ulemas who refused to swear obedience were executed.

The Arabic Spring has been analyzed from a Western perspective as an attempt to embrace freedoms and democracy by the people, but we cannot really deny that the power vacuum left in many countries has helped terrorist groups to operate with total impunity. Salafist networks occupy an important place among them. A considerable part of the rebels believe that fighting is a part of Jihad. As such, the Arab Spring has turned into a race between radicals and kleptocratic governments trying to organize themselves, when they are not yet prepared to govern under the norms of political reasoning, very different from religious thinking. The consequences of the problems in the power structures have strengthened the loyalists of Al Qaeda, and other diverse groups are also in search of the imposition of Sharia law.

\section{The Development of Fundamentalist Movements. Islamic State Jihadism}

In June 2014, on the first day of Ramadan, Abu Bakr al Baghdadi proclaimed himself in front of the world the Islamic State's (IS) caliph, also known by its acronym in Arabic as Daesh. And as such, since his very first public appearance in the Iraqi city of Mosul, al Baghdadi has called Muslims to follow his postulates. The political entity that is the IS, is first and foremost, a war machine, and wants to revive the religious and spiritual leadership of the Umma, the Muslim community of believers, by recovering the caliphate, the symbolic institution extinct since 1924 . In the $21^{\text {st }}$ century, the institution of the caliphate irrupts again, claiming to be a source of legitimacy for the IS, to support its dark plans of conquest and terror. ${ }^{9}$

9 Ataturk provided the "coup de grace" to the Ottoman Empire, and allowed its secularization and modernization getting rid of its political and religious leader, the Caliph. 


\subsection{The Caliphate: origins and development.}

The subject of the Caliphate goes all the way back through Muslim history, occupying a central role in debates about the organization of Islamic power. ${ }^{10}$

The Caliphate was born to solve a specific political problem, the power vacuum left after the prophet's death. The continuity of the "Mohammedian" project was at stake, and with it, the birth of Islam, still at an embryonic stage, hence the election of the "successor" in the immediate aftermath of the prophet's death. In the religious hierarchy, the caliph is the "supreme guide" in charge of protecting and spreading the divine message, the first officiant of the collective prayer, and the guardian of the religion and holy places. In the political sphere, he manages the empire's administration and names his subordinates and representatives in the different provinces; he is in charge of providing justice, manages taxation and is the supreme chief of the armed forces. Since the beginning of the Institution, the Caliphate has been an ideal concept, adapted in different moments and circumstances. The restitution of the Caliphate has taken place in heterogeneous situations throughout history. The source of all legitimate power in Islam, as the "successor" of Mohammed, the caliph represents the umma, from which the importance of its symbolism derives. It is therefore in the Islamic State's interest to carry through its reinstitution. ${ }^{11}$

\subsection{The Caliphate: organization and division of power}

The term "caliphate" was originally used by Mohammed's disciples to continue with the religious system established by the prophet, known as the Rashidun's Caliphates. A "caliphate" is also a state implementing this type of political system.

The Caliph's power is similar to the Roman kings' power, which concentrated all authority in a single person: the king is the religious, political, military leader, justice administrator and interpreter of the divine will. The Caliph is the highest spiritual leader. The Sultan is the leader of the armed forces, he is in charge of war and financial matters. The Emir is responsible for the administration of justice. The chamberlains have the same functions as the sultans and emirs; they are equivalent to other countries' prime ministers. Visirs maintain control of their territory inside the Caliphate by force. They were instituted by the Caliphate to avoid further disagreement. The visir's limits in his territory are determined

10 In his Prolegomena, a historian and sociologist Ibn Jaldun (1332-1406) highlights the Caliph's double role, political and religious, as the prophet's successor.

11 D. Alvarado, El Estado Islámico y la reinvención del califato, "El Universal"19.04.2015, available at http://www.eluniversal.com/opinion/150419/el-estado-islamico-y-la-reinvencion-del-califato, accessed 20 January 2016. 
according to his military strength. The visir's powers are delegated partially or entirely by the sultan. ${ }^{12}$

Regarding the central Muslim administration, the divan (group of secretaries) work in territories. They are classified in two branches: "the quill group" and "the sword group." The divan is presided over by the visir or hachiv. The Muslim system has two different bases: donations and tribute. Donations are divided in two groups: one of them is aimed at charity and the other one is for social aims. The tribute comes from conquered regions. The Azaque taxes annually income and goods and the percentage is calculated according to what is taxed. The mucus taxes foreign goods at $10 \%$. Any other tribute imposed by the prince, not having a Quranic base, is illegal. The Muslim treasury is backed up by the prince's personal fortune, and the prince is the one who pays the principality's administrative expenses.

In terms of juridical Islamic organization, the juridical power was given by God to Mohammed and by Him to the Caliph, which is then delegated by a judge, known as a cadi. There are two instances and two competences for each part of the law. There are civil judges, called cadi, and penal and religious ones, known as $z a$ baxorta, lastly those of the court of appeal that had executive functions. The judges were assisted by a caliph and assessed by two witnesses whose honorability was guaranteed by the mozaqui. After that they were named official witnesses. Each judge had a hachiv who carried out the procedures and was paid by the litigants.

The way to adapt Muslim law to the present world, and also link their leaders to those under their command, is based on the custom, conventions, juridical stratagem, fiction and the prince's legislation. The Conventions' goal is to modify the original pact. The legal strategy and the narrative are created, so that the Muslim does not disobey the law nor violate Allah's precepts. The prince is not allowed to legislate or to create tributes. However, the law acknowledges that, without the measures imposed by him, the state would be ungovernable and the prince would not fulfill his mission. For this reason, in parallel to the religious nizam, there is a derivative of the King called ganoan, who establishes a type of counterweight to religious rule.

\subsection{The Islamic State (IS). Development and Ideology}

The Islamic State is a terrorist, rebel group of jihadist Sunni nature, a self-proclaimed caliphate, settled on a broad territory. Technically, the group is organized

12 M. Gaudefroy-Demombynes, El califato musulman, "Revista de Administración Pública", no. $6,1951$. 
as a non-recognized state, ${ }^{13}$ declaring the intention to create a caliphate that would extend throughout the whole Muslim world. Abu Bakr al-Baghdadi is designated as its highest authority, the self-proclaimed "Ibrahim, iman and caliph of all Muslims." 14

With this intention, the group was renamed Islamic State, in response to their desire for expansion: "the legality of all emirates, groups, states and organizations is rendered null and void after the expansion of the Caliph's authority and the arrival of his troops." In practice, they call themselves a caliphate following the model of the former Islamic kingdoms, but it is a terrorist group which has managed to capture territory and establish a prototype of a de facto state. ${ }^{15}$ Just like many other jihadist groups, IS is a radical, Salafist group. ${ }^{16}$

Salafism is a Sharia (Islamic law) school, derived from Wahabism. The Salaph were the first three generations of Muslim believers - under the Rashidun caliphate, and according to them it was the ideal Islamic State, pure in its composition. The most radical Salafists want to impose that idealized order on every Muslim. ${ }^{17}$ Its main characteristic is to be a plebeian mass rejecting the traditional Islamic elite, because they believe it is corrupted. This means that religious interpretation

13 Originally known as the Organization for monotheism and jihad, it was born as a terrorist organization, close to Al Qaeda, to face the Invasion of Iraq (2003). It was led by Abu Musab al Zarqaui. After his death, the new leader, Rashid al-Baghdadi, under the tutelage of Osama bin Laden, expanded through those governing Ambar province, Nínive, Kirkuk and a big part of Saladino, and also, but in a smaller measure through Babilone, Diala and Baghdad. During that time, it was proclaimed the Islamic State of Iraq, and its headquarters were in the city of Baquba. The Islamic State renewed during the Syrian Civil War becoming the Islamic State of Iraq and the East or their Arab acronym Daesh or Daech. Their following and current leader, Bakr al-Baghdadi, cut relations with Al Qaeda and declared in 2014, their Independence and their sovereignty over Iraq and Syria, proclaiming himself Caliph under the name of Ibrahim.

14 Historically, we can recognize four previous periods in the development of the current Islamic State: Islamic militia: Ŷama at al-Tawhīdwal-Ŷihād ( since it was born until 2003); Direct dependence on Al Qaeda: Tanzim Qaidat al-Jihad fi Bilad al-Rafidayn (2003-2006); Indirect dependence on Al Qaeda: Islamic State of Irak (2006-2013); Syrian Civil War and independence from Al Qaeda: the Islamic State of Iraq and the East (2013-2014).

15 P. Cockburn, Isis. El retorno de la yihad, Planeta, Madrid 2015.

16 F. Soní, ¿Es ISIS realmente un Estado?, 15.10.2015, available at http://revistafal.com/ es-isis-realmente-un-estado/, accessed 20 January 2016.

17 F. Aznar, Doctrina y acción política. Pugnas sobre el islam verdadero. El salafismo, in: Yihadismo en el mundo actual, Documentos de Seguridad y Defensa, Ministerio de Defensa no. 62, 2014, pp. 17-42. 
would not be in the hands of ulemas and Sharia experts, but in those of the fighters themselves, which means that, due to their ignorance in Islamic law (Fiqh), their interpretation of the Quran and Sharia is based exclusively in these texts and in the Sunnah (the verbally transmitted teachings of the prophet), which makes it possible for them to be radically textualist. The Salafists make accusations of apostasy and heresy (takfir) against other Muslims (mainly Shias), which, in turn, are used to justify their attacks and atrocities committed against the Salafists. In this way, IS justifies attacks against anyone who is not loyal to the Caliph. ${ }^{18}$ Salafism is opposed to nationalism because the imagined community they feel a part of is the umma (the community of all Muslim believers) and even if conventional Islam does not see any contradiction between nation and umma, it is not compatible for them. Nationalism in the Middle East has been secular. ${ }^{19}$

The name jihadist describes those who, feeling to be at the vanguard of Islam, pronounce themselves in favor of armed struggle, instead of religious preaching. Jihadism is a Western neologism used to name the most violent and radical branches of political Islam, characterized by the frequent and brutal use of terrorism, in the name of a supposed jihad, called by its followers a "holy war" in the name of Allah. ${ }^{20}$ Jihad, as a basic concept of Islam, is a debated question. It has two accepted definitions: the "lesser jihad" of violent inspiration, where the jihadist tries to legitimize himself, and the "greater jihad" of spiritual interpretation, representing the effort that every believer needs to make to be a better Muslim, a better father, mother, spouse or person. Ideologically, jihadism as a political doctrine is a theoretical and totalitarian group of ideas with an anti-liberal and anti-democratic viewpoint which, according to its critics, "systematically disregards human life." That is the reason why it is considered by many as one of the most serious threats faced by liberal democracies, particularly in Western countries.

Jihadism as a derivation of Salafism is a heterogeneous phenomena in which diverse interpretations about how to return to Islam's origins coexist. All these doctrinal principles agree on restoring the grandeur of Islam, re-Islamizing Muslim societies to the most strict orthodoxy and the aspiration of creating political structures looking out for and promoting the achievement of these principles. The

18 B. Rougier, Qu'est-ce que le salafisme?, Presses Universitaires de France, Paris 2008.

19 Atatürk in Turkey, Gamal Abdel Nasser in Egypt, Hafez al Assad in Syria and Mohamed Reza Pahlevi in Iran, all tried to "de-islamize" their societies and remove the clergy's power, and it caused a clerical and conservative reaction, like the Salafism promoted from Saudi Arabia against the Arab republics.

20 S. Amghar, Le salafisme en Europe: la mouvance polymorphe d'une radicalisation, "Politique Étrangère", no. 1, 2006. 
acting environment may only be regional but all the lines coincide in that they wish to achieve every the union of all Muslims and the will of extending Islam all over the planet. The priority given to each objective and the methods to be used to achieve these objectives, depend on the historical and political characteristics of each region, which define the differences between groups. ${ }^{21}$

Their objectives are generally gradual and, in the medium term, they involve the overthrow of governments ruled by moderate Muslims, that they consider apostates, impious and corrupt because they are half-hearted, hypocritical and friends of Western countries - these are most of the Muslim countries, Saudi Arabia included, which has been targeted by jihadists trying to overthrow its monarchy. They try to consolidate power in like-minded states since from the beginning their objective is expansion, and they intend to recover the Islamic territories "taken from them illegitimately," and re-create a radical Islamic order over the whole world.

In recent times, the most radical doctrines aiming at the global jihad - whose priority is to fight against Western countries until death - have been consolidated. For the theorist of radical Islam, inviting those responsible for the new age of religious ignorance, or jahiliyyah, to be a part of Islam is unacceptable. The only way to rehabilitate Westerners is by killing them in such great numbers that their conversion and submission will be real and humble. ${ }^{22}$

Islamic terrorism has manipulated the concept of jihad with ideological fundamentalists affirming an international plot against Islam coming from the most powerful Western countries. Under this argument, the radical Islamists have manipulated jihad to the degree of translating it into a totalitarian ideology justifying brutality and considering it an obligation of every Muslim to spread terror in Western countries, destabilize the governability of those states and weaken or destroy its liberal democracies. ${ }^{23}$

Politically, without forgetting the lack of separation between politics and religion, IS defends a theocratic system. Theocracy (from Greek $\theta \varepsilon o$ c [theós], 'god' and крátoৎ [kratos], 'power', 'government') is a form of government in which governmental leaders coincide with the leaders of the dominating religion, so that

21 G. Arístegui, La Yihad en España, La obsesión por reconquistar Al-Ándalus, La esfera de los libros, Madrid 2005.

22 M. R. Torres, El eco del terror. Ideología y propaganda en el terrorismo yihadista, Plaza \& Valdés, Madrid 2009.

23 M. Espino, Yihadismo, una amenaza mundial que puede estar operando en México, Friends of Israel Initiative, No. 27 2015, available at http://www.friendsofisraelinitiative. org/uploads/papers/pdf/FOI_Paper27.pdf, acceseed 20 January 2016. 
the governing politics are identical with, or much influenced by, the principles of the main religion. ${ }^{24} \mathrm{~A}$ theocracy [theokratian] confers power and authority to God, author of all the good things. ${ }^{25}$ The umma, or community, is the basic political unit of Islam. Its main mission is religious: the propagation of the divine message. However, to obtain this goal, it needs to organize itself from a political point of view. ${ }^{26}$ The political authority is inscribed in the same line, as the one in charge of supervising that the observance of sacred law provides the umma with the capacity of observing its divine mission. Sovereignty, therefore, does not reside in the political establishment nor in the religious one, but in the word of God himself, specified in the form of Sharia. ${ }^{27}$ But it is also a totalitarian theocracy.

In spite of the difficulty in establishing adequate terminology, autocracy can be defined by its opposition to democracy. Autocracy, if it is in a significant degree, invades all the fields in the political and social life of a country, and its main characteristic is that of the concentration of power in a single person, an ethnic or religious group or in a "movement" or party, and the subsequent diminishment or annulation of the citizens' freedoms. Considered from a legal establishment of rights, or should we say the lack or repression of these, we find ourselves in front of a totalitarian regime in which a person is not treated as an "end in itself but as a piece of a whole, an instrumental sable mean." ${ }^{28}$

Totalitarianism or totalitarian regimes differ from other autocratic regimes in that they are led by a political party that claims to be - or, in practice, acts as - the only legitimate party having control over all state institutions. ${ }^{29}$ These regimes exalt, in general, the figure of a leader who has an unlimited power, reaching into every aspect of society and manifesting itself through its authority exercised hierarchically. They drive a mass movement in which the intention is to remake the whole society (with the purpose of forming a new person in a perfect society)

24 Wikipedia, available at https://es.wikipedia.org, accessed 20 January 2016.

25 F. Josefo, Antigüedades y guerras de los judíos, Editorial Luarna, Madrid 2012.

26 M. Ayoob, Many Faces of Political Islam: Religion and Politics in the Muslim World, University of Michigan Press, Michigan 2009.

27 P. Crone, M. Hinds, God's Caliph: Religious Authority in the First Centuries of Islam, Cambridge University Press, Cambridge 1986.

28 A. Torres Del Moral, Estado de Derecho y Democracia de partidos, SPUCM, Madrid 2010, p. 288.

29 J.J. Linz, Sistemas totalitarios y regímenes autoritarios, Centro de Estudios Públicos y Constitucionales, Madrid 1977. 
and they make intense use of propaganda and other means of social control and repressive mechanisms like the secret police. ${ }^{30}$

Totalitarianism is a form of State, a way of organizing the four components of the State itself: territory, population, government, power, and, according to the author, also the law and the judicial system. Totalitarianism is not simply a type of government, it is an organization around the people in power, a type of non-democratic state. Authoritarianism has as its main characteristic the lack of acknowledgement of freedom and human rights. However, the difference between totalitarianism and authoritarianism is that, in the former, is characterized by a privation of freedom and individual rights, non-recognition of the human beings' dignity, and turning the social classes into masses. ${ }^{31}$

Totalitarianism considers the state as an end in itself, and therefore seeks to maximize it. Given that power exists for other things to be achieved, it follows that, if the State is considered an end, these two components of politics are correlative; as a consequence, a larger state gives us more power. In this way, the power of the totalitarian state can do everything because it is an end in itself, which contains everything. Mussolini (who used for the first time the term "totalitarianism") created the slogan "everything in the State, everything for the State, nothing outside the State, nothing against the State." It is not the state for people, but the people for the state.

In its political aspect, totalitarianism implies political monism because all the power structure turns around political power, concentrated generally in a single leader who absorbs all the political powers and denies those who oppose him or are independent. Unlike in democratic states, where political power is just one of the powers, which in a hierarchy is on top of social power, in totalitarianism that hierarchy does not exist because there is only one power, a total political power. A primary characteristic of the state is the exaltation of an omnipotent or totalitarian state, bringing respect for the leaders almost to a level of "a cult of personality."

In the sociological aspect, totalitarianism defends the sociological monism, because its ideology rejects the concept of person as an free-will possessing individual in favor of another concept in which subjectivity is reduced to the status of a part of society. In light of this conception, human being is human precisely insofar as he/she is a member of society, and not an individual.

30 G. Hermet, Totalitarismos, Fondo de Cultura Económica, Mexico 1981.

31 R. Aron, Democracia y totalitarismo, Seix Barral, Madrid 1968. 


\subsection{The Islamic State as a State ${ }^{32}$}

The State has resisted a clear definition. Its complexity determines that, in the attempt to define it, it is necessary to turn not only to legal aspects but also to historical and ideological events, and to the way power is executed. The global jihadist project is inspired by the desire of driving the Muslim world to a new wave of progress and expansion at all levels: political, economic, cultural, religious, etc. These aspirations lead to a double and essential purpose: to unify the whole Islamic community and its territories under a single flag, and to install a new caliphate supported by the strict principles of the Salafist ideology. At the same time, achieving these goals would require previous completion of three other long-term objectives: ${ }^{33}$

To reduce or eliminate the influences of non-believing governments over the Muslim world, particularly those influenced by Western nations but not only. To bring down the present apostate governments established in Muslim countries and replace their political institutions of Western inspiration by theocratic regimes, ordered according to the jihadist Salafist interpretation of Islamic law or Sharia.

Re-conquer the territories that were a part of the Islamic world. This would include, naturally, Palestine and Israel, wide regions of Spain and Portugal, the Balkans, the Mediterranean islands, Greece and the south of Italy.

The caliphate does not accept other political or administrative frontiers than those imposed by the sharia. If, according to Torres del Moral, ${ }^{34}$ the state is the institutional organization of a national community with a sovereign political power, can we consider the model established by the IS as a state? Given that its goal is to build a new state, it seems reasonable to question how closely the caliphate is being built into a State. A state needs to be a sovereign political institution with an administrative and legal frame maintaining the legitimate monopoly on violence inside its territory in order to maintain the established order. ${ }^{35}$

In the long term, once the conflict is stabilized, it would be possible to analyze if the caliphate is a sovereign or not, if sovereignty is understood as the capacity of a State to act in the international system in a relatively autonomous way. The

32 F. Soní, ¿Es ISIS realmente...op.cit.

33 L. De la Corte, Yihadismo global: una visión panorámica, in Yihadismo en el mundo actual, Documentos de Seguridad y Defensa, no. 62, 2014, p. 49.

34 A. Torres Del Moral, Estado de Derecho y Democracia de partidos, SPUCM, Madrid 2010, p. 288.

35 M. Weber, Economía y sociedad. Esbozo de sociología comprensiva, FCE, Mexico 1964. 
limits of sovereignty are the acting capacities of other states. Therefore, the most powerful states are also the most sovereign ones, but even the weakest state keeps some capacity to act in an autonomous way to define its internal politics. The IS, however, is acting as if it were a de facto sovereign state, with no fear of contravening international laws or human rights, which implies that at least its internal politics is defined in a completely "sovereign" way.

The first condition to establish a state is the monopoly of force. In the first instance, it is not necessary that it is legitimate, as eventually legitimacy is obtained by virtue of the interest of whoever monopolizes the use of the force, benefitting out of it in the long-term within its territory, and promoting in this way the establishment of order in the territory that increases economic growth. One could expect that, by monopolizing the use of violence, the IS, $\mathrm{n}$ by means of peace and economic benefits, would build an administrative system allowing it to raise taxes and become legitimate in the eyes of the population.

To monopolize the use of violence and to take measures to institutionalize it, the group establishes its Islamic courts according to Sharia and organizes jihadists to carry out the work of the police. What is more, it establishes a secret police to control the population in a more efficient way. However, the radical application of Sharia - which imposes punishment such as mutilation, executions, crucifixions and slavery - could cost them legitimacy. In spite of the price of their atrocities, it should not be forgotten that these methods have facilitated the conquest of many cities, such as Mosul, where the Iraqi army ran away instead of facing this jihadist group, which executes its prisoners on a daily basis.

Islamic State combines both charismatic and traditional domination. Regarding traditional domination, the IS bases the control of the conquered territories in pacts with the local tribes, promising in exchange economic benefits depending on the resources which it controls (water and petrol) and organizing the administration according to Sharia. It searches for legitimacy by means of populist measures, such as the redistribution of wealth, the sharing out of food and petrol and the prosecution of commercial abuse.

The survival of this de facto State is yet to be seen, both because of the warring situation and the adaptations they would have to make to a government structure which is based on $7^{\text {th }}$ century laws, the share of the power and the resources with their tribal allies and the tensions between Iraqis and foreign fighters whose interests are divergent. These adaptations will provoke tensions in the Salafist movement, because of the possible "deviation of a radical Salafism when re-interpreting Sharia to make it applicable to a functional state."

In an attempt to conceptualize the state phenomena, we speak of a state when a certain population, living permanently in a delimited territory, is subjected to a 
group of rules and concrete institutions. Analyzing the previous attempt of definition, the existence of various elements or compounds of the state phenomena can be obtained. The three elements we have highlighted in the State, and without which the State would not exist, are: people, territory and power.

However, it needs to be considered that the State is not a simple arithmetical addition of these three elements, but that they reach a determined interaction when connected with each other, creating a unit that cannot be considered separately and this is what, in particular, gives sense to the State concept. ${ }^{36}$ Heller refers to the State as a domination unit, independent in its internal and external matters, which acts in a continuous way, having its own means of power, and clearly delimitated. ${ }^{37} \mathrm{In}$ this way, as Heller indicates when analyzing these elements of the State, we must not forget in any case that it acquires full activity and reality only in its reciprocal interrelation. The previous affirmation does not mean that these three elements cannot exist separately, creating certain situations, but that these situations do not determine the existence of a State. That is the reason why the State elements must not be mistaken by the State. That is the reason why the State's elements should not be mistaken for the State itself.

In general terms, power is the capacity of a person or a group to impose his will and decisions within a certain community. In this first approach to the term, we can highlight several substantial aspects which we consider necessary for its execution. In the first place, it is worth highlighting the capacity and strength to execute a certain will or decision and, in the second place, we should point to the target group's acceptance to obey what is ordered. But power - political power - needs the legitimation of its acts, and this legitimation, in today's democratic societies, cannot be anything other than the "Rational" legitimation, which means the existence of a series of rules which are accepted by the community, and according to which power is executed. It is therefore a society that has its base in the law, and the law canalizes the relationship between leaders and those who are governed. Thus, it implies a high degree of institutionalization of power. Faced with this legitimation, traditional legitimation is based on the respect and the trust that the community has in its ancestral customs and habits, which determine the adequate execution of power.

Faced with these forms of legitimacy, we find "charismatic" legitimation, whose base is in the special characteristics of those who execute power. Those who hold power need to have a certain personal and prestigious conditions

36 C. Núñez, J.M. Goig, M. A. Núñez, Teoría del Estado Constitucional, Editorial Universitas, Madrid 2010, p. 18.

37 H. Heller, Teoría del Estado, Fondo de Cultura Económica, Mexico 1955. 
which differentiate them from the rest of the community members, such as religious values, ethical values, etc. It has an autocratic nature and it corresponds to the historical phase of the personal, not institutionalized power. It is typical of underdeveloped countries and autocratic regimes and dictatorships, and it is in this environment that we would place the legitimacy the IS finds in the execution of the power, which is acquired through force.

In traditional Islam, the concept of state, government and, in general, the public is rigorously theoretical. After fourteen centuries of existence, this has generated hundreds of sects and excisions. Although the belief that sovereignty belongs to God, and not to the people, is not exclusive of this religious practice, and in a historical phase many cultures have based their political systems in the divine right, only in the Islam (the meaning of this word is "surrender", "submission") this school of thought has been kept until today.

The consequences for Muslim societies, particularly in the present, of the theocratic dogma, have been a complete disaster. Due to the fact that sovereignty belongs exclusively to God, the adverse effects multiply themselves: if the leader is the Creator's direct agent, he is exempted from accountability for his actions over the governed. Only God can judge its public administration. This argument has served historically to justify the autocratic regimes, and in the specific case of the Islamic State it is still working to reject the democratic system and accuses it of being against divine sovereignty. At this moment in time, Islamic revivalists of the $21^{\text {st }}$ century, conservatives and revolutionaries are reclaiming the divine sovereignty's dogma to justify autocracies. What is more, they add that this dogma is an inalienable part of the so-called "Islamic identity."

The IS does no defend a Muslim state, but an Islamic state: a state not defined by the fact that those in power confess to being Muslims, but because the whole system is structured on the basis of real Islamic law. The absolute sovereignty has its roots in Allah (al-hakimiyya) and therefore humans can only apply this sacred law which is superior and fairer than any other system created by humanity in the human history. There will be three pillars in the new Islamic State: the priority of religion in all aspects of life (din), the superiority of the community of believers over the differences of race, skin color or social condition (umma), and the absolute submission to Allah, as any power is executed by the people only insofar as they participate in the divine revelation $(\mathrm{hukm}) .^{38}$

38 J. Cepelledo, Modelos de organización política de la umma en la historia del pensamiento islámico, "Cuadernos electrónicos de Filosofia del Derecho" no. 22, 2011. 


\section{Jihadi Consequences on the International Order}

The IS has come to stay. It has the organization, the strength and the support needed to go on with its activity for a long time. It has a territorial base to start working and building its goals. The proclaimed Islamic Caliphate controls the territory, the roads, the economy, the society and has enough popular support to consolidate its power. Unlike other terrorist groups that Western countries have fought against recently, the IS has decided to unite the Muslim world under a single flag, though through its methods it has no morality in the eyes of humanity, anything goes which follows Islamic laws, or at least their interpretation of them. Their fundamentalism makes them unique.

This has some unexpected consequences, which, in turn, may lead to unknown outcomes. The consequences can be found on different levels: economic consequences, political - not merely within its territory but everywhere, in internal and external security, and in the field of human rights - and regional and international consequences. ${ }^{39}$ IS terrorist consequences reach the whole planet and this reflects the need for a holistic response from every state's powers and a solid and properly built international cooperation faced with a "shared" threat. This fight cannot only focus on repressive action, since the international community is facing a terrorism with new features that requires fast and effective response. The fight against violent fundamentalism still holds a key role in any effective response strategy. It is essential to develop wide fighting strategies against violent extremism at an international level, to fight radicalization. The foreign terrorist fighters present an important threat to peace and security. The jihadist flow to conflict zones has been widely expanded. But the worry is not only how it feeds the international lack of stability. The greatest fear in the long term is that they can return to their countries of origin trained and with orders to attack. To break this cycle, the members of the United Nations Security Council urged to reinforce the international cooperation to identify them, chase them and to adopt measures to prevent radicalization.

The Security Council adopted, as promoted by the United States of America, a resolution that established a legal framework to respond to the growing threat posed by foreign terrorist fighters. But, despite the adopted measures, the flow of terrorists continues and that is why some new measures need to be adopted to stop a phenomenon that knows no borders.

39 I. Fernández-Molina, Islamismo y Relaciones Internacionales, in: Actas de las I Jornadas de Estudios de Seguridad de la Comunidad de Estudios de Seguridad, UNED, Madrid 2009. 
The Resolution 2178 (2014) is another piece in the fight against jihadism, and requires all Member States to prevent entry or transit through their territories of any individual about whom that State had credible information of their terrorist-related intentions. It also urges the exchange of information about terrorist suspect lists or criminal investigations. As recently stated by the United Nations (S/2015/358), there is no single, simple solution to this multifaceted problem. Disrupting the flow of foreign terrorist fighters and the threat that they pose presents an unprecedented challenge and will involve significant expense for Member States. Preventing radicalization in the first place and successfully screening, monitoring or rehabilitating returnees are at the heart of an effective global response. So too is the immediate need to improve analytical understanding of the problem and operational information and intelligence sharing within national Governments and between the Member States; in particular, by taking further steps to share watch list information on individuals of interest. Privacy, data protection and sensitivity of information concerns complicate this vital priority. The full implementation of preventive measures under Security Council resolution 2178 (2014) would be a major step forward. Intensified efforts with regard to prevention and returnee policies, including further work in relation to the Internet and social media, are crucial.

\section{Europe Faced with Jihadist Terrorism}

The attacks to the United States on September $11^{\text {th }}, 2001$, exposed the gravity and the seriousness of the jihadist threat to the Western world's collective subconscious. Since then, the European Union member states have tried to offer a coherent and collective response in the face of this transnational threat to thus guarantee the security of its citizens.

These efforts were reflected in theEuropean Security Strategy, approved in 2003, and in the European Union's Counter-Terrorism Strategy adopted in 2005. Overall, these documents have articulated the general strands of the European Union's response against a jihadist threat that, since its appearance on the international scene with the attacks of 2001, has been clearly determined by the actions of a specific organization: Al Qaeda.

Faced with the new situation caused by the emergence of IS, or ISIS in current British usage, the EU has reacted formulating two interrelated strategies: the Counter-Terrorism Strategy for Syria and Iraq, with particular focus on foreign fighters, and the regional strategy for Syria and Iraq as well as the Daesh threat.

Although the Lisbon Treaty, approved in 2007, does not directly make significant changes to resources nor to the existing general lines of the strategy against 
jihadism, many of its regulations open the door to potential improvements in the capacities and possibilities of action against jihadism abroad: ${ }^{40}$

- By conferring a specific legal personality on the Union through article 47 , it is allowed that, from now on, the EU can sign international agreements about terrorism with other countries.

- The treaty contemplates, through article 43 , that the EU may carry on civil and military missions to support third countries in the fight against terrorism.

- The introduction of the mutual defense clause, article 42.7 TEU, and of the solidarity clause, article 222 of the Treaty on the Functioning of the European Union, leave the door open so that the EU can mobilize all the necessary instruments, including military resources, to respond to a potential terrorist attack.

After the jihadist attacks in Spain, London, Denmark and France, the countries that make up the European Union adopted the challenge of reinforcing their internal and external control mechanisms to avoid new terrorist actions. The terrorist threat has fostered "the political opportunity" to get measures off the ground that had been tucked away, for their possible violation of human rights, and that now are more likely to be launched. The Regional Strategy for Syria and Iraq and the Daesh's threat, adopted by the Council on March $16^{\text {th }}, 2015$, has a twofold objective: countering the threat from Daesh and other terrorist groups in order to get regional and international stability, and creating the conditions to achieve an inclusive political transition in Syria and sustainable stability in Syria, Iraq and the wider region. One of the aspects that the International Community and groups concerned with International Human Rights law have been most concerned with is the use by the United States of restrictive human rights measures under the protection of the security against terrorism.

The legislative reforms in matters of terrorism adopted by different countries have followed common guidelines: extended pre-charge detention time, judicial reorganization processes, with amendments to the appeal system and the presentation of evidence, reduction of secret telephone and cybernetic communications, even allowing the interception of telephone communications without a warrant, or admitting "preventive interception." Secret service and police powers have also been expanded to fight against terrorism, facilitating the exchange of

40 F. Ruiz, La estrategia de la UE contra el yihadismo en tiempos de ISIS, Instituto Español de Estudios Estratégicos, no. 17, 2005. 
information between different agencies, and the access to certain personal data without a court order.

This set of actions has resulted in the reinforcement of the State, with the consequent emergence of murky areas, where the fundamental rights and freedoms result, in some aspects, more fragile and precarious than in the past, offering weak protection to individuals against the pressure applied by terrorism, ${ }^{41}$ and such regulations may collide with the international standards that regulate the restrictions of rights, according to which, every measure to repeal, suspension or restriction of civil rights and freedoms must strictly accomplish certain requirements: that the rules are accessible, foreseeable and precise; that the restriction on rights is justified; that the restriction is necessary in a democratic society; that it is proportionate to the legitimate aim pursued and the reasons that motivate it; and that it is not discriminatory.

Security and the fight against terrorism are interests shared by all the European Union member states ${ }^{42}$ as well as respect for human rights and democracy. As a result of the Arab Spring, a massive migration toward Europe, mainly by sea, took place from the countries involved, becoming the largest migrant wave known in Europe. In response to the situation, the European Neighborhood Policy (ENP) was reviewed, with the establishment of new elements, such as: 1 .The so-called 3 Ms: "markets, money and mobility;" 2. the "more for more" principle (advance more with the neighbors that progress more); 3 . the principle of differentiation, to "adapt" the Neighborhood Policy to the context in each country.

The review of the European Union's political strategies toward North African Mediterranean countries had proven the urge to support the strengthening of some very incipient democracies to guarantee sustainable economic growth, without thereby having to renounce the strong frontier control to prevent the massive entrance of migrants. The European Union implemented the new external border surveillance system called Eurosur with the aim of improving the fight against irregular migration and organized crime, and at the same time, reinforced the frontier controls through Frontex, whose promotion and reform has been gradual and progressive.

41 M. Fernández, La amenaza terrorista en la unión europea: reacción legislativa común y estatal, "Revista Aequitas" no. 2, 2011, pp. 113-153.

42 A. Aixalá, La estrategia de la Unión Europea ante el terrorismo internacional y la defensa de los Derechos y Libertades, in: Política exterior y Parlamento Europeo: hacia el equilibrio entre eficacia y democracia, M. Barbé, A. Herranz (eds.), 2007 available at http://www.recercat.cat/bitstream/handle/2072/204360/6\%20cap\%204.pdf?sequence $=6$, accessed 20 January 2016. 


\subsection{Common European immigration and asylum policies}

The EU has created a common asylum policy so that asylum-seekers rejected in a country cannot apply again in another Schengen country. This common policy was implemented with the Dublin Convention in 1990 and followed with the execution of the EURODAC system and the Dublin II Regulation IN 2003 and nowadays is still in use. In October 2009 two European Commission proposals were adopted, to provide for a single asylum procedure and the equity of a uniform status, valid throughout the European Union: the parts for the final construction of a for international protection. The Stockholm Programme, adopted by the European Council in December 2009, establishes the EU measures and priorities regarding international protection between 2010 and 2014.

With its adoption in June 2013, the European Union recast asylum procedure; the Member States will begin the process for the modification of national legislation so that it reflects the agreed changes. The EU, through a long and difficult process, has tried to face the migration policy as a European policy, establishing common elements to an array of regulation that has included many aspects: legal migration, irregular migration, asylum and refuge as well as integration policies. However, there is still a long way to go until the EU adopts a true common policy on the subject. Recently, terrorism and illegal migration are threatening one of the EU's most important principles, free circulation, and for that reason we need to address the way to manage the security in our frontiers without damaging the rights and freedoms of the immigrants, and without betraying the European Union's principles. Recent events may contribute to putting together the fight against terrorism, the European common foreign policy, especially toward the Middle East, border control, free circulation, the fight against irregular immigration and the integration in our societies of minorities from different cultures or religions.

In 2015, there was an increase of irregular immigration, boosted by different factors such as: the wave of conflicts in the Middle East (especially the problems in Libya and Syria); the demographic pressures in Africa; the increase in human trafficking as a result of the development of organized crime; the economic emigration from the Balkans, and the EU's own difficulties in managing in a consistent manner its frontiers. To all these factors we need to add the challenge of jihadist terrorism, that may require greater controls inside and outside our frontiers, and, above all the adequate management of the refugee claims in the EU's territory.

Besides the defense and diplomacy principles, and an adequate asylum and refugee policy, it is necessary to strengthen European foreign policy, so that it develops a proper cooperation and development policy with our neighbors, a crucial element for an adequate migrant policy. However, the area in which the 
EU must remain determined is regarding free circulation, to maintain the political and civil project developed over a long process, because free circulation of people is a fundamental right that assists the EU's citizens according to the Treaties The Schengen agreement, as part of the EU's judicial and institutional framework, has gradually expanded to include the majority of the member States and some nonEU countries, and is expressed through the area of free movement, security and justice without internal frontiers. The suppression of internal frontiers implies a stronger management of the external frontiers of the Union as well as the regulation of the entrance and residence of people from the non-EU countries through the use of measures like the common asylum and immigration policy.

The fourth dimension of the European project refers to its role as global actor in an international system characterized by fast and intense changes in its surroundings, the source and the rules of the distribution of power. The State Members, and the EU as such, would only manage to stay relevant and promote their interests and values abroad through a common foreign policy, and in particular through the Common Foreign and Security Policy (CFSP), including the Common Security and Defense Policy (CSDP).

The global and integrated perspective for the Community Policy on Migration suggested by the EU, and formally supported by the governments of the State members, is revealing itself as a declaration of principles. In fact, in recent years, the EU has demonstrated a total incapacity of developing a joint policy on migration, coherent and multidimensional: the migration management is still characterized by the outsourcing of Community frontiers, the fight against "uncontrollable" immigration, and the definition of different and discriminating legal status amongst the migrating community. This vision has shown itself to be more incomplete and one-sided each time, as well as insufficient and incorrect. The control of the EU's borders at any price is leading to a lack of criteria of transparency, legality and humanity, and to violations of the legality and human rights of migrants. ${ }^{43}$

The Opinion of the Committee of the Regions - "The efforts to promote genuine solidarity on a real European migration policy” (2015/C 019/12), of 21 January 2015, recalls that fifteen years after the first attempts to draw up a common migration policy, there is still a wide gap between practice and the principles and stated values. There has been insufficient recourse to Article 80 TFEU for adopting measures implementing solidarity and fair sharing of responsibility with regard to mobility, including its financial implications, between the Member States. Commitments

43 E. Bazzaco, La Unión Europea frente a los procesos migratorios: lejos de una política integral, "Papeles" no. 104, 2008/2009. 
concerning mobility, migration and repatriation have been entirely voluntary, and considers that, in such a sensitive and strategic area, the European Union and its chief institutions should shape a genuine migration policy and assume the political responsibility for its implementation. This task should not be left up to individual states, particularly the border States.

The European Union migration policy regarding the control and management of migratory flow, can be looked at from multiple perspectives. Besides the economic dimension, the defensive aspect states the need to secure frontiers from irregular migration in order to ensure both security and law and order. Also, the social aspect needs to be considered, acknowledging the immigrants' rights and freedoms according to the Constitution, and the need to integrate immigrants through rights and obligations. ${ }^{44}$ The economic crisis and its social effects, as well as terrorism, are causing the implementation of more restrictive policies in the EU regarding asylum and migration, bringing into question the founding values of the Union and the Lisbon Treaty on the subject of Human Rights. The $5^{\text {th }}$ Annual Report on Immigration and Asylum (2013) from the Commission has expressed the need to take action at the EU level to support Member States tackle the challenges of responding to migratory pressures, in full respect of migrants' fundamental rights.

Regarding the establishment of a Common Asylum Process, the Common European Asylum System (CEAS) has claimed to be a maximum priority for the EU. The CEAS intends to provide better access to the asylum procedure for those who seek protection; lead to fairer, quicker and better quality asylum decisions; ensure that people in fear of persecution will not be returned to danger; and provide dignified and decent conditions both for those who apply for asylum and those who are granted international protection within the EU. In an area of open borders and freedom of movement, the EU must apply a joint approach to asylum across the EU, since asylum is a fundamental right and granting it is an international obligation under the 1951 Geneva Convention on the protection of refugees.

New EU rules have finally been agreed, setting out common high standards and stronger cooperation procedures to ensure that asylum seekers are treated equally in an open and fair system - wherever they apply. This set of rules is integrated by several regulations: the revised Asylum Procedures Directive; the revised Reception Conditions Directive; the revised Qualification Directive; the revised Dublin Regulation, and the revised Eurodac Regulation. The modified

44 A. Solanes, La política de inmigración en la Unión Europea. Desde tres claves, "Arbor" no. 713 (181), 2005. 
legislation has the potential to substantially contribute to harmonizing the asylum systems throughout the Union. If they are properly incorporated into national legislation and applied according to the principles governing the CEAS, the recast legislation could provide an adequate identification and qualification of people in need of international protection.

In 2015, more than half a million asylum-seekers arrived in Italy, Greece and Hungary by land and sea. There was, and there is, a consensus that the three states cannot face the economic, demographic and political challenge, since we are in what could be the worst moment of forced displacements since the Second World War. Action must be taken, but the EU has not been up to the task, it has been overwhelmed when dealing with refugees, and disagreements have arisen at the heart of the EU. Germany, Sweden, Spain, the host countries and France, are in favor of the distribution quotas and are accepting, or will accept, all the refugees requested by the EU. At the same time, however, Hungary, the Czech Republic and Slovakia have blocked the development of an asylum policy according to European principles. International law says that every refugee - who is actually a refugee - that arrives to European territory has the right to be granted asylum. Nonetheless, the fragility of the asylum systems in the EU needs to be clarified.

The centrality of the refugee crisis is due to the fact that Europe's foundational values are at stake. Either the EU is able to provide an effective and supportive response to the refugees' arrival or it will not be what it always meant to be and what the rest of the world thinks it is: a civil and humanitarian power; a territory that was able to convert the most terrible violence amongst neighbors into a beautiful experiment in peace, where respect for human rights is a natural part of civic society. Recent events showed that the EU's legislation on asylum has not been applied consistently throughout the Union to date. The divergent national legislations and asylum procedures question the global objective of granting equal and dignified life conditions to the refugees. Basic rights such as health, education or work are clearly under question. The limitations and restrictions imposed turn the asylum seekers into second-class citizens.

The current refugee and immigrant crisis can only be managed through a common EU emergency response. The individual measures taken by each country will not solve the problem and will worsen an already chaotic situation, increasing people's suffering and the tension among states at a time when Europe needs more trust and solidarity. The restrictive measures recently adopted by some States, especially Hungary, and the way they are being implemented, extraordinarily limiting the refugees' access through the border, including the use of dissuasive measures, would infringe the international law and European jurisprudence. At 
the beginning, the EU played an important and brilliant role in the asylum and refugee crisis: Greece, despite its profound economic crisis has received the thousands of people who have overflowed on its coasts and ports on a daily basis and Germany initially assumed an historic role in terms of solidarity. The two of them have joined Italy, who has taken on a fundamental role in the Mediterranean rescue process. The Commission and the Parliament also requested a European response, based on the European principles and values. However, recently, there has been a profound modification in EU policy regarding immigration and above all asylum and refuge.

The Justice and Home Affairs Council meeting on 9 November 2015 established the need to modify the registration process, ignoring the asylum seekers free choice (most of the refugees still prefer Germany or Sweden, States with a more generous reception program). It also addressed relocation - States like Finland, Luxembourg, France or Spain have already received the first refugees, although at a very slow pace - and another key subject was border protection, laying bare the border control policy that defines the European migration policy. In that last point, it was agreed to reinforce Frontex, and the Commission even presented a proposal to create a border guard before the end of 2015. The Migration summit held in Malta on November $11^{\text {th }}$ and $12^{\text {th }}, 2015$ has outlined as its final objective to limit the economic and security problems caused by the current migration flow. The Valletta summit has consummated the policy of border closures. The idea of how to help the refugees has been replaced with how to prevent new arrivals; the refugees' security focus has also been replaced with ours; there has been a change from the protection of the right to life or the recognition of the right of asylum, to our right to have safe borders. It is not anymore about how to integrate the immigrants, refugees or asylum seekers, but how to send them back to their countries of origin. ${ }^{45}$

Instead of placing the foreign and development policies at the service of the European project, a new border policy is adopted, with a prevalence of security in general and in particular, the security of each European state. This tendency has increased since the jihadist attacks against France on November $13^{\text {th }}$. However, we understand that using walls and barriers is not the answer, and the use of scare tactics, putting the security and well-being of some in favor of the rights of others is also not the solution. Recent events have influenced again EU policy against

45 J. I. Torreblanca, Cierre, "El País" 13.11.2013, available at http://elpais.com/elpais/2015/11/13/opinion/1447432847_417991.html, accessed 20 January 2016. 
terrorism. IS has exported to the heart of Europe the most inhuman methods to spread terror.

On Friday (November $13^{\text {th }}$ ), six attacks took place in Paris almost simultaneously: four shooting, a bomb attack near the Stade de France and a hostagetaking at a concert hall. The IS claimed responsibility for the 130 deaths and 352 wounded. France responded by declaring war, declaring a state of emergency and establishing strict border controls by security forces, and the suspension of the Schengen agreement. France's initial response has been extended to the rest of the EU. The EU's behavior should consider two facts. The first of them is to properly address the debate around Islam's role in our societies. Islam is based on a series of ideological aspects of great significance: Islam's incompatibility with democracy; Muslim integration; the role of religion in public places; identity; multiculturalism and the need to control the migration, asylum and refugee flow. The second fact lies in the need to combine resources to face jihadist terrorism, turning to the rule of law; security forces, intelligence services, court access, etc. without giving up on the proportionate use of force, according to the idea that democracies have the right to defend themselves from these kinds of acts. In the EU, the solidarity clause introduced by Article 222 of the TFEU, anticipates the competence to mobilize all the instruments at its disposal, including military resources, in case of terrorist attack.

The Paris attacks follow the ones against the Charlie Hebdo magazine and a Jewish grocery store, also in French territory, and the Mali hotel hijack. They all expose that jihadist terrorism, especially from the IS, plays a significant role not only causing instability in Iraq and Syria, but it is also able to hit at the heart of Europe and, together with the territorial conquest - the goal of taking over Jordan and Saudi Arabia - the imposition of a tax system in the areas under its control, and the creation of new external operation units, all these aspects show its power and political organization.

Without reaching the complexity of the attack against the United States on September $11^{\text {th }}, 2001$, jihadism has used bombs again to target Europe, in this case Paris, but previously Toulouse and London, the biggest attacks since the ones in March 11 $1^{\text {th }}, 2004$ in Madrid. The necessary conditions to face this problem are not to be carried away by outbursts that could mix up defense from jihadists with coexistence with Muslim communities, and not putting into question the basic freedoms that make the difference between Europe and its attackers.

Unrest in Africa and the Middle East has affected Europe in two ways: as an asylum and refugee crisis whose magnitude has never been seen before, and with an unprecedented terrorist threat, that requires an effective response. This response 
has to face the mistakes in the current European policy, it has to provide asylum and refuge to those persecuted by the IS, and it has to improve the intelligence services and the legal and police resources, without forgetting the diplomacy to force a negotiation, and harassing the IS with financial, military and supply measures.

The first consequence of the Paris attacks has been the creation of a support front for France, from Moscow, the USA and the EU, to French and Russian bombers attacking IS in Syria. The EU will provide France with military support to face the terrorist threat and have, on November $17^{\text {th }}$, activated the duty of military assistance amongst States regulated in art. 42.7 of the Community Treaties which establishes that "if a Member State is the victim of armed aggression on its territory, the other Member States shall have toward it an obligation of aid and assistance by all the means in their power," a mechanism that has been used for the first time since its existence and that demands bilateral offers.

The Paris attacks have also struck at the heart of the difficult process of receiving refugees in Europe, fueling the States who are reluctant to receive the asylum seekers and refugees and sowing fear in the rest. Hungary is the State most interested in establishing a link between terrorists and refugees and its parliament has already passed, on November $17^{\text {th }}$, a law that allows to the appeal against the European Court of Justice the Community decision of the program for the distribution of foreigners despite the fact that, until now, Frontex has dismissed the hypothesis that there is any hint suggesting that jihadists are using the routes into Europe that the asylum seekers are undertaking.

Another important effect from the attacks is the abandonment of the concept, supported by several democratic States in its relationships with the Islamic world, of putting forward safety as a priority, to the point of even defending tyrannical leaders or dictators, followed by a good governance, believing that stability is attractive regardless of which is the political model that ensures such stability. On the contrary, at present it is advocated that good governance is decisive for long lasting stability, and that this governability requires organic development whose model could possibly be the Quartet for the national dialogue in Tunisia.

In terms of rights and freedoms, the attacks have also had a great impact. After the Paris attacks, President Hollande, declared a state of emergency, but French law established that this could only be maintained for 12 days. In order to extend it to three months, the French Government submitted a project, approved in the National Assembly and the Senate which, in the name of the fight against terror, includes important limitations to civil liberties, among them the possibility of home searches at any time, with no need for a legal authorization, including the possibility of copying any computer data or data which is kept in any other format, without any 
previous legal authorization; it could also dictate house arrest and being detained incommunicado for those on suspicion, and an electronic wristband could be placed on those who are recidivist in order to assure their confinement. It is also allows the banning of meetings and assemblies in public places, as well as dissolving associations or groups that participate, facilitate or encourage any type of act that might threaten public order, and establishes the possibility of blocking certain web sites and social networks. The basis for this legal modification, justified by the idea that the "state of emergency is not against the rule of law but that it tends to protect it" should reconcile security with the proportionality of its measures and their time limit, and in the necessity of maintaining and defending the freedom of information, with the exception of the essential restrictions, in order to allow the mass media to be instruments for highlighting any eventual abuses or malfunctions in the application of the emergency measures. A state of siege has also been declared in Brussels, where the Belgium government has already announced a legislative reform package in similar terms to the one done by France.

It is without doubt border control, where the attacks have had the greatest impact. The Council of Ministers of Justice and Interior has, on November $20^{\text {th }}$, 2015, agreed on a series of measures that directly affect one of the pillars of the EU: the leading measure is to review Schengen; an automatic registry has been activated which includes the fingerprinting of nationals from third countries that come illegally into the Schengen area, whether they might be migrants or seeking international protection, there will also be systematical controls in critical points within the Europe Union and, in addition to that, the immediate creation of the PNR, passenger name record, which will store the flying data for at least one year.

The UN has passed a resolution to fight ISIS with "all necessary measures" in compliance with international law, in all territories controlled by ISIS as well as any other groups, individuals and entities associated with Al Qaeda and any other terrorist group, condemning in its "strongest terms the continuous, extended and systematic abuses of human rights and humanitarian laws." Although the resolution does not call on Chapter 7 of the United Nations Charter, which is what would provide it with a legal basis for the use of force, it does acknowledge that, in accordance with art. 42.7 of European Treaties, all Member States shall have toward it an obligation of aid and assistance by all means in their power, accordingly to art. 51 of the United Nations Charter.

The last measure proposed by Brussels is to transform Frontex from being a border control coordination body into a kind of European Agency of Border Guards, equipped with numerous agents who can be mobilized by the EU to alleviate the border crisis - up to fifteen European countries border either by land or sea on a 
non-Schengen country. Even though this measure could clash with the fact that most of the immigrants are refugees, the fact is that the EU measures, who is moving in a vague and rash way, have the common goal to restrict the rights of immigrants and refugees - and, in some of them, to their own citizens, as well as to increase the sovereignty given to the States at the expense of a real foreign policy for the EU.

\section{Conclusion}

To the new situation that has led to the emergence of the Islamic State, the EU reacted by formulating various strategies regarding terrorism jihadist in Arabia, Syria and other African States, although it is accurate to say that the terrorist threat has led to "the political opportunity" related to adopting measures that were reserved or hidden, as they constituted possible violations of human rights under the aegis of the Defense against terrorism.

At the same time, legislative measures on terrorism adopted by different countries, such as France, United Kingdom, Holland, Hungary, Sweden, etc., have followed common guidelines: increasing the time of duration of pre-trial detention, reorganization of the judicial process, with changes in the system of resources and presentation of evidence, attenuation of the secret of the telephone and cyber communication, allowing even the interception of telephone communications without a warrant, or admitting the "preventive interception." Faculties, both intelligence and police, have also increased in the fight against terrorism, facilitating the exchange of information among the various agencies and access to certain data of a personal nature without judicial authorization.

This set of trends has been the reinforcement of the Member States, a common position of the EU, and the birth of situations of tension, or breach, which rights and freedoms are, in some respects, more fragile and precarious than before, offering weak protection to individuals against pressures exerted by terrorism, and it can collide with international standards governing the restrictions of rights, in virtue of which, any measure of suspension, limitation or restriction of rights and freedoms must comply strictly certain requirements: that the standards are accessible, predictable and precise; to justify the restriction of rights; that restriction is necessary in a democratic society; it is provided with the objectives pursued and the reasons that motivate it; and that it is not discriminatory.

Security and the fight against terrorism are interests shared by all European States, but so are the respect for human rights and democracy.

Today, it is essential to harmonize the resources to deal with jihadist terrorism, and is at the moment in which, without renouncing the use provided force (the clause of solidarity referred to in article 222 of the TFEU, foresees the mobilization 
of all available means, including the military), in the event of a terrorist attack, on the idea that democracies have the right to protection against such acts you have to resort to the instruments of the rule of law (security forces, intelligence services, courts, and respect for human rights).

The economic crisis and its social effects, and jihadist terrorism, are leading to that in the EU are applied, too, more restrictive policies on migration and asylum, to call into question the fundamental values of the Union and the content of the Treaty of Lisbon in the field of human rights.

Instability in Africa and the Middle East has affected Europe in two ways: as a crisis of asylum and refuge of a magnitude unknown so far, and with a terrorist threat without precedent, which requires you to build an effective response that happens, once found mistakes in European policy, to asylum and refuge to the persecuted by the ISIS, and improving intelligence and police and judicial, not forgetting the activation of diplomacy to force a negotiation, and harass the EI with financial measures and supply, as well as military.

Although it has been, without doubt, in the control of borders, where jihadist attacks have had greater consequences, we cannot ignore that, in terms of rights and freedoms, the attacks have also had an important consequence.

The internal and external security cannot be the argument for taking disproportionate measures restrictive of rights and freedoms. International law rights remain an important canon of protection. A community's "foreign policy" has to be common and co-ordinated with other intergovernmental entities, which fight against jihadist terrorism, promoting policies of co-development in different States and respecting all rights and freedoms.

\section{References}

D. Alvarado, El Estado Islámico y la reinvención del califato, "El Universal" 19.04.2015, available at http://www.eluniversal.com/opinion/150419/el-estado-islamico-y-la-reinvencion-del-califato, accessed 20 January 2016.

A. Aixalá, La estrategia de la Unión Europea ante el terrorismo internacional y la defensa de los Derechos y Libertades, in: Política exterior y Parlamento Europeo: hacia el equilibrio entre eficacia y democracia M. Barbé, A. Herranz (eds.), 2007, avilable at http://www.recercat.cat/bitstream/handle/2072/204360/6\%20 cap\%204.pdf?sequence $=6$, accessed 20 January 2016.

S. Amghar, Le salafisme en Europe: la mouvance polymorphe d'une radicalisation, "Politique Étrangère", no. 1, 2006.

G. Arístegui, La Yihad en España, La obsesión por reconquistar Al-Ándalus, La esfera de los libros, Madrid 2005. 
R. Aron, Democracia y totalitarismo, Seix Barral, Madrid 1968.

M. Ayoob, Many Faces of Political Islam: Religion and Politics in the Muslim World, University of Michigan Press, Michigan 2009.

F. Aznar, Doctrina y acción política. Pugnas sobre el islam verdadero. El salafismo, in: Yihadismo en el mundo actual, Documentos de Seguridad y Defensa, Ministerio de Defensa no. 62, 2014.

E. Bazzaco, La Unión Europea frente a los procesos migratorios: lejos de una política integral, "Papeles" no. 104, 2008/2009.

T. Cartalucci, 2011: Year of the dupe 2011, Land Destroyer Report, available at http://landdestroyer.blogspot.com/2011/12/2011-year-of-dupe.html, accessed 1 December 2015.

J. Cepelledo, Modelos de organización política de la umma en la historia del pensamiento islámico, "Cuadernos electrónicos de Filosofia del Derecho" no. 22, 2011.

P. Cockburn, Isis. El retorno de la yihad, Planeta, Madrid 2015.

P. Crone, M. Hinds, God's Caliph: Religious Authority in the First Centuries of Islam, Cambridge University Press, Cambridge 1986.

L. De la Corte, Yihadismo global: una visión panorámica, in: Yihadismo en el mundo actual, Documentos de Seguridad y Defensa, no. 62, 2014, pp. 49.

M. Espino, Yihadismo, una amenaza mundial que puede estar operando en México, Friends of Israel Initiative, no. 27 2015, available at http://www.friendsofisraelinitiative.org/uploads/papers/pdf/FOI_Paper27.pdf, accessed 20 January 2016.

I. Fernández-Molina, Islamismo y Relaciones Internacionales, in Actas de las I Jornadas de Estudios de Seguridad de la Comunidad de Estudios de Seguridad, UNED, Madrid 2009.

M. Fernández, La amenaza terrorista en la unión europea: reacción legislativa común y estatal, "Revista Aequitas" no. 2, 2011, pp. 113-153.

M. Gaudefroy-Demombynes, El califato musulman, "Revista de Administración Pública" no. 6, 1951.

H. Heller, Teoría del Estado, Fondo de Cultura Económica, Mexico 1955.

G. Hermet, Totalitarismos, Fondo de Cultura Económica, México 1981.

F. Josefo, Antigüedades y guerras de los judíos, Ed. Luarna, Madrid 2012.

J. J. Linz, Sistemas totalitarios y regímenes autoritarios, Centro de Estudios Públicos y Constitucionales, Madrid 1977.

S. Mangana, Las protestas en los países árabes son en respuesta al inmovilismo político, Vadenuevo no. 31, Montevideo 2011, available at https://www.vadenuevo.com.uy/index.php/faq/105-entrevistas/2064-31vadenuevo01, accessed 20 January 2016. 
M. Weber, Economía y sociedad. Esbozo de sociología comprensiva, FCE, Mexico 1964.

P. Morillas, Lo que queda de la primavera árabe, cuatro años después, "Política Exterior" no. 163, 2015.

C. Núñez, J.M. Goig, M. A. Núñez, Teoría del Estado Constitucional, Editorial Universitas, Madrid 2010, pp. 16.

J. Núñez, Apuntes de urgencia sobre la oleada de cambios en el Mundo Árabe, Instituto de Estudios sobre Conflictos y Acción Humanitaria (IECAH), Fundación Carolina, no. 18, 2011, pp. 39-43.

I. Ramonet, Cinco causas de la insurrección árabe, "Le Monde Diplomatique" 05.03.2011, available at http://www.monde-diplomatique.es/?url=editorial/0000856412872168186811102294251000/editorial/?articulo=8ca803e0-5eba-4c95-908f-64a36ee042fd, accessed 20 January 2016.

B. Rougier, Qu'est-ce que le salafisme?, Presses Universitaires de France, Paris 2008.

F. Ruiz, La estrategia de la UE contra el yihadismo en tiempos de ISIS, Instituto español de estudios estratégicos, no. 17, 2005.

A. Solanes, La política de inmigración en la Unión Europea. Desde tres claves, "Arbor" no. 713 (181), 2005.

F. Soní, ¿Es ISIS realmente un Estado?, 15.10.2015, available at http://revistafal. com/es-isis- realmente-un-estado/, accessed 20 January 2016.

J. I. Torreblanca, Cierre, "El País" 13.11.2013, available at http://elpais.com/elpais/2015/11/13/opinion/1447432847_417991.html, accessed 20 January 2016.

M. R. Torres, El eco del terror. Ideología y propaganda en el terrorismo yihadista, Plaza \& Valdés, Madrid 2009.

A. Torres Del Moral, Estado de Derecho y Democracia de partidos, SPUCM, Madrid 2010.

B. S. Turner, La ciudadanía árabe: la Primavera Árabe y sus consecuencias no intencionales, "Sociología Histórica", no. 1, 2012.

VVAA., La Primavera Árabe y sus consecuencias, “Journal Alif”, no. 98, 2011.

VVAA., Escenarios post-Primavera Árabe: actores y dinámicas de cambio, "Journal CIDOB d'Afers Internacionals" no. 109, 2015. 


\section{Daniel Przastek and Elżbieta Borowska}

\section{Theme of Terrorism in Art of the $21^{\text {st }}$ Century}

\section{Introduction: Terrorism as a form of Political Theatre}

Contemporary art is a reflection of reality, of the world outside our window. The phenomena of contemporary culture are meaningful only when they relate and refer to the issues, which are current and relevant to us, issues which demonstrate that the substance of art is not detached from the life of society. Artists themselves tend to avoid topics that are not connected with the present-day world. An artistic creation has more to it than only offering entertainment, with greater goals than purely portrayal of beauty or presentation of artistic skills. The main aim of artistic works is to refer to social phenomena that affect the life of both the local and global community. Artists, being part of these communities, react to their maladies and in their artwork they depict the world as they see it. Referring to the life of other citizens as well as topicality constitute important elements of artistic life. Thus, the notion of political theatre should be mentioned here. It is commonly believed that political theatre was first introduced by Erwin Piscator, ${ }^{1}$ a German stage artist and producer, one of the exponents of the great transformation of theatre that took place at the beginning of the twentieth century - the Great Reform of Theatre. It was then that the stage producer became the key person in theatrical production. Those artists staged plays with all means available, making actors, scenery and music work toward a single goal, namely - a spectacle. Piscator chose to fill the stage with current politics. His style of work was rooted in his historical experience. His performances were in the form of graphic collages showing the absurdity of war, social inequality as well as injustice and denigration suffered by the man in the street. From then on social issues were widely present in the world of theatre of the day. "Truth and nothing but the truth" became the theatre's main motto. Theatre portrayed the rhythm of the streets, its pounding and atmosphere. This pulsating rhythm and topicality started to take more and more space of the stage. All contemporary technical novelties were employed - screens, cinematographs, light and shadow effects. This convention echoed newspaper pages, full of political slogans and brutality of everyday life. It became increasingly common to grip the audience with extremely suggestive images, in order to depict the

1 See: E. Piscator, Teatr polityczny, Wydawnictwa Artystyczne i Filmowe, Warsaw 1982. 
maladies of the contemporary world. This picture forms the basis for a definition of political theatre. According to a dictionary, it is "a theatre form dealing with specific political events and representing a specific political agenda. Artists practicing this form of theatre use various stage means and types of text. (...) A radical form of political theatre is agit-pop, propaganda theatre. (...) In its broad, metaphorical meaning, political theatre encompasses works and performances portraying the mechanisms of political life and concerning the moral aspects of power, etc. Through an analysis (...) they invite the viewers to look at the reality from the political perspective." 2 At the time the above definition was created, that is in the 1990s, the issue of terrorism, signaled in this article's title, was not among the most urgent political concerns of the world. It was not a global but a niche phenomenon, and hence treated as marginal also by the artistic world. The experience of the attack on the World Trade Center on 11 September 2001 caused artists to take a closer interest in this area. The theme of terrorism was broadly introduced to the public debate.

In order to specify the scope of the theme of terrorism, for the purpose of this article the definitions described below have been adopted. The word terrorism is derived from the Greek word treo, which means to tremble, to fear, to funk, to escape, the Latin word terreo - to inspire alarm, and oris - to inspire fear. This demonstrates that the aim of terrorism is to inspire dread and fear. Intimidation. In the contemporary perspective, terrorism should be distinguished from terror - that is methods used toward own citizens in order to operate a system of repression, use of violence by government bodies and security services, invigilation. Terrorism, instead, involves planned and long-term use of violence toward specific government structures and social groups. ${ }^{3}$ Its victims are defenseless people, regular citizens and random passers-by that happen to be at the place of the incident. Its objective lies not in the sheer use of violence. An important aim of terrorism is spreading specific ideas through mass media which provide a broad commentary on any terrorist attacks.

The issue of international security is nowadays in the forefront of the minds of contemporary politicians all around the world. The strategies to ensure common security and fight terrorism are discussed among politicians of the highest rank and each incident is instantly covered by the mass media. This issue affects and inspires artists as well as art critics. Violence, conflict, abuse of force have

2 M. Semil, E. Wysińska, Słownik współczesnego teatru. Twórcy, teatry, teorie, Wydawnictwa Artystyczne i Filomowe, Warsaw 1990, p. 357.

3 See: W. Dietl, K. Hirschmann, R. Tophoven, Terroryzm, Wydawnictwo PWN, Warsaw 2009. 
indeed always been an important motif in artistic work. This may be viewed from a twofold perspective. On the one hand, in terms of inspiration to artists who in their works deal with the subject of brutal social phenomena. One of the first to use war trauma as an art motif was Francisco Goya, a Spanish painter working for the Bourbon dynasty. In his series The Disasters of War he showed the consequences of Napoleonic battles. The works by Pablo Picasso or poet Blas de Otero, inspired by the bombarding of Guernica in 1937, are in a similar spirit. Both of them created anti-war pieces in homage to the murdered. Analogically, nowadays artists in their works make artistic use of acts of terrorism. However, there is also another aspect of violence in art. It concerns limitations imposed on controversial work. In such a situation it is the art of work that falls victim to violence. For instance, Olympia by Edouard Manet, painted in 1863, portraying a nude prostitute wearing only expensive jewels and a pair of shoes slipping off, meeting the viewer with a provocative stare. Such a thing could not be accepted by the audience in the second half of the nineteenth century. The outraged audience in protest stabbed the painting with umbrellas. Similar behavior was observed in Poland, and already after 1989. The exhibitions in the National Gallery of Art "Zachęta" should in particular be mentioned here. In November 2000, a famous Polish actor, accompanied by journalists, damaged with a sabre some works being part of the exhibition by Piotr Uklański, The Nazi. The installation combined 164 photos of famous actors wearing Nazi uniforms from the movies they played in. The photos were displayed without any caption or commentary. A month later, during a jubilee exhibition an installation by Maurizio Cattelan, The Ninth Hour, was presented. It consisted of a sculpture of Pope John Paul II smashed to the ground by a meteorite. This sparked an outrage among right-wing journalists and MPs. At first, the figure was covered with a white sheet (shroud) by a journalist and traveller, Wojciech Cejrowski, and later the rock was removed by members of the Polish Parliament - Halina Nowina-Konopczyna and Witold Tomczak. Thus, the work of art was damaged. ${ }^{4}$ The incidents described above reveal a broader tendency to limit freedom of artistic expression in Poland. They can be deemed violence against artistic activity. They are a consequence of interpreting and assessing art according to moral and religious standards instead of aesthetic categories. This results from an insufficient level of cultural education. Artistic events are analyzed in a direct manner, without necessary perspective or

4 The account of actions aimed at limiting the freedom of artistic expression in Poland can be found in: J. Minałto (ed.), Kronika wypadków cenzorskich. Ostatnie lata, „Notatnik Teatralny" no. 39-40, 2006, pp. 9-23. 
background. Though it is an important problem related to artists' freedom and independence, it does not constitute the central topic of this article. The main subject of this article is artists' involvement in the analysis of phenomena from the world of politics, namely the issue of terrorism.

This concern stems from several reasons. The modern world is full of anxieties and dangers and thus a fertile source of inspiration for artists. Social consequences of terrorist attacks constitute an important feature of emotional and personal accounts as well as a significant factor behind motivation and behavior of individuals - both victims and terrorists. In this way they create one of the forms of political theatre - the theatre of fact, presenting real events filtered through emotions of the artist. The analysis presented below will focus on modern forms of artistic activity referring to the acts of terrorism that took place in Europe in the $20^{\text {th }}$ and the $21^{\text {st }}$ century. It will refer to the works by Torsten Buchsteiner, Simon Stephens and Małgorzata Sikorska-Miszczuk, who in their plays deal with the issue of the threat posed by terrorism to the contemporary order of our part of the world. In their works they invoke the events related to German terrorism, the conflict between Chechnya and Russia and the events that took place in London in 2005. Their works do not constitute, however, a grand political variety show, characteristic of Erwin Piscator, but are rather intimate dramas aimed at showing the emotions and behavior of individuals. What they all have in common although one of the works bears some grotesque undertones - is an attempt at drawing the viewers' attention to the struggle experienced by individuals, their feelings and attitudes toward the tragic events.

The thesis points out that artists, being part of society, in their works deal with various problems that are crucial to the way the community functions. The diagnoses formulated by them, conveyed through multi-layered metaphors, significantly add to creating social awareness and constitute an important element of the discourse on contemporary terrorism, as well as its place and meaning in relation to art. It is also extremely relevant and important documentary work, performed far ahead of the efforts of historians and journalists. Such plays take on a deeper meaning during onstage performances, when the presented facts are clashed with the interpretation proposed by the stage producer, and with its reception by the audience. Thus, the works enter the public domain and become a lasting element of culture. This, in turn, develops awareness among the viewers.

5 The analysis of plays presented below includes theses and arguments from a dissertation written under my supervision: E. Borowska, Obraz terroryzmu w europejskich dramatach XXI wieku, Warsaw 2011. 
Hence, a social bond is created, demonstrating that the issue of terrorism does not concern only the narrow circle of politicians but affects also artists and audiences of artistic events, and in a broader perspective - the entire society.

When analyzing the phenomenon of terrorism in the context of art, one more possible interpretation is also worth mentioning. The words by an American expert on security, Brian Jenkins, will form a good starting point. Jenkins claimed that: "Terrorism is theatre (...) directed at those who are watching (...). Terrorist attacks are often carefully choreographed to attract the attention of the electronic media and international press." ${ }^{\prime \prime}$ An act of terrorism becomes a spectacle which through its form is aimed at drawing the attention of public opinion to certain facts and demands made by attackers. Based on the above observation, terrorism, under a radical approach, may be called performance art. Indeed, it is a demonstrated, exhibited activity and its actual presentation. It is a specific behavior, that is, what people do when they are actually doing it. This thesis was put forward by an American performance studies professor, academic, editor, theatre director and critic, Richard Schechner. According to Schechner, terrorism is a specific kind of multicultural social drama, and in the globalized world it affects more and more people. ${ }^{7}$ It involves actors, a clearly planned scenario and, as a result of media coverage, a mass audience.

The phenomenon of terrorism was fittingly presented by a Lebanese artist Rabih Mroué, who translated it into the language of theatre in a form of a performative lecture, with elements of film, editing and documentary work. His trilogy is a fascinating unmasking of terrorists, showing how their political activity is based on self-creation. The video footages with the last words of terrorists who were about to make a suicide attack show how they manipulate with words for the purpose of self-creation. The posters with jihadists placed around Syria turned out to be fabricated. Photos of uniforms were used as a base, and smiling faces of dead militants were pasted on them. Not only are acts of terrorism performances but they also inspire further performative action. The same happens in the context of writing drama. The real events of terrorist attacks become an inspiration for drama works and later on, staging activity in the form of a theatrical performance. Thus, a double performance appears. The one from the real life, being a presentation of certain activity in the form of a terrorist attack becomes an artistic phenomenon

6 W. Dietl, Terroryzm...op.cit., p. 14.

7 See: R. Schechner, Performatyka. Wstęp, Ośrodek Jerzego Grotowskiego, Wrocław 2006, pp. 299-318. 
within a closed space of the theatre building. It is worth underlining how real events become fictional and affect social attitudes.

Acts of terrorism are the subject of theatrical pieces more and more often. As already mentioned, this theme should be viewed as related to political theatre, however, a certain difference may be observed. The model of stage activity practiced by Piscator was aimed at social change. His performances were supposed to inspire the viewer, make him rethink his opinions. This was the objective of the various forms of propaganda or revolutionary theatre which propagated specified values or were directed at transforming the old order. In this context, in the contemporary theatre the theme of terrorism functions as a commentary, as presentation of certain phenomena. It is not used as an important component meant to influence the audience or achieve specific attitudes. One of the first plays dealing with the issue of the attack on the WTC in New York is Happiness by Laurie Anderson, written in 2002. It is by no means an enthusiastic propaganda work, but rather an account of feelings experienced by society after the attacks of September $11^{\text {th }}, 2001$. Contemporary plays dealing with the issue of terrorism do not create the same universe as the historical political theatre used to do. Here, art is supposed to caution against the idea of combat and its consequences. It becomes a warning, a question mark. These artworks are also an effect of fascination with specific figures involved in terrorist organizations. An example of such an object of fascination may be Ulrike Meinhof, co-founder of the German Red Army Faction. Today, she is treated as a pop-cultural phenomenon and an inspiration for playwrights.

\section{Rote Armee Fraktion in Pop Culture}

The way the terrorist movement developed in West Germany at the end of 1960s derived from the social landscape of that country. On the one hand, during years 1966-67 the country suffered an economic recession, which significantly challenged the myth of it being an economic miracle and disturbed the sense of economic stability among its citizens. At that time, one of the most urgent problems, both for the Western Europe and the United States, was the birth rate - a consequence of the end of the Second World War. The young generation had its ambitions, dreams and own idea of how their life should look like, and they expected broad access to education, more liberal moral and social rules and more places at universities. This type of mind-set gave rise to the student movement of the 60s. Moreover, there was one more unresolved problem with which the Federal Republic of Germany struggled - namely, the attitude toward the past. The young were very suspicious toward the generation which had been involved in 
the functioning of the Third Reich. Denazification had not eradicated all former Gestapo officers and SS members from society. Some of them still held public offices, with the tacit approval of the community. History was a taboo and many pretended not to remember the times of war. Eventually, children turned against their parents, demanding to hear the truth about the past. ${ }^{8}$ The youths expressed their protest against their teachers and role models. The state authorities were castigated as incapable of introducing changes in the country, and the foreign policy was criticized as well, for the lack of a clear stand condemning the US operations in Vietnam. In such a climate, on 2 June 1967, Ulrike Meinhof, a 33-year-old journalist, published an article in which she objected to the visit of the Iranian shah, Reza Pahlavi. As a result, a student protest was organized, during which Berno Ohnesorg was shot to death in unexplained circumstances. It was this event that the first terrorist organization in Germany named itself after - the 2 June Movement. As an act of revenge, this extremely leftist group set fire to several shops in Frankfurt am Main. This is the origin of the Red Army Faction, led by Andreas Baader and Ulrike Meinhof. Meinhof joined the group in 1970 and became their main theoretician. She gave up her quiet life of a mother of twins and went through a training organized by the Palestinian organization of Al Fatah. Engaging in bloodshed combat, proclaiming radical, extremist slogans, robbing and murdering, at the same time she maintained that all this was in defense of oppressed and unaware masses. This left-wing journalist underwent an incredible transformation. Once renouncing violence as a means of political strife, she then turned into a symbol of one of the most savage gangs which considered armed struggle the only just method of action. A criminal act thus became a political act. And since combat required victims, innocent people were killed in the name of more and more radical slogans. In 1976 Meinhof committed suicide in a cell after being sentenced to life imprisonment. ${ }^{9}$ The history of the RAF is a source of many legends and myths but it also became a mirror of certain trends which can still be found in the mass culture. Evil has always been appealing. Medieval witches burned at the stake or public executions by beheading always attracted crowds of onlookers. Baader and Meinhof are a contemporary version of Bonnie and Clyde - young, risk-seeking, breaking all the rules and ready to commit to an all-or-nothing fight in the name of some abstract ideas, vague to all but themselves. The aura of unlawfulness, defiance and madness impressed the young and

8 See: M. Tomczak, Terroryzm w RFN $i$ w Berlinie Zachodnim, Instytut Zachodni, Poznań 1986.

9 See: V. Grotowicz, Terroryzm w Europie Zachodniej. W imię narodu i lepszej sprawy, Wydawnictwo PWN, Warsaw 2000. 
stimulated their imagination. There was one more reason. As observed by Ewa Wójciak, actress and leader of the student Theatre of the Eight Day which performed at the same time the RAF first terrorist acts were carried out: "Our small group disapproved of the fact that there was a general acceptance of the way the system treated people. There is this sort of helplessness and despair which creeps into the minds of young persons when they cannot reach out to society to voice their dislike for certain things. In such a situation, any action aimed at helping people shake off indifference and apathy seems worth considering." ${ }^{10}$ These words appear extremely fitting as they point to the profound powerlessness experienced in everyday life when the only thing left is the struggle for the cherished ideas and values, even if most people do not share them. The aura of unlawfulness, rebelliousness and lunacy the RAF was surrounded by stirred the minds of the young. The spectacular form of terrorist attacks, their bravado and creativity, attracted a growing audience, and also guaranteed media coverage. In this way the media boosted their profits and ratings among their audiences. The popularity of the Baader-Meinhof gang has had its impact also on artists who today still refer to this story. However, a certain pattern can be observed. In Poland, emphasis is put on the figure of Ulrike Meinhof, her life story of a person forced to take decisive actions and stand up in the name of certain values. In Germany, the RAF is seen from a different angle. It is considered one of the unresolved problems regarding own history and identity. Similarly to the awareness that the Nazi period was not properly accounted for, the terrorist incidents are analogically interpreted as a result of the process which breeds violence. Individual motivation is treated as of secondary importance. What becomes important is the sole terrorist activity however, devoid of any deeper interpretation or reasoning. Coercion and abuse of force are pictured as a pastime enjoyed by the gang members. This has been well interpreted by Elfriede Jelinek. Her play Ulrike Maria Stuart directed by Nicolas Stemann at the Thalia Theater in Hamburg ${ }^{11}$ suggests that the ideological combat was not given primary importance at all. The play focuses instead on the conflict between Ulrike Meinhof and Gudrun Ensslin, representing the figures of Maria Stuart and Elisabeth I, who clash not over political ideas but rather over the attention of Andreas Baader. In one of the scenes the director chose a satirical musical form to portray the heroines as two giant vaginas arguing over whom of the two the terrorist prefers. This depicts a certain struggle for femininity and the right

10 Statement by Ewa Wójciak from an interview with E. Wójciak, Ł. Drewniak, Z. Jakubowska, G. Laszuk, M. Liber, Jak nie być Ulrike Meinhof, "Dialog” no. 5, 2007.

11 See: A. Krzemiński, Dzieci Hitlera?, "Dialog” no. 5, 2007. 
to express one's sexuality. Madness and private goals obscured the once valued ideals. Jelinek's text was one of the voices in a wide-ranging discussion on the real motivation behind the RAF's activity, which opened new areas of interpretation. This also demonstrates how well-rooted the phenomenon of the German terrorist group is in the public memory. However, its perception bears no insight - it is rather an element of pop culture. Just as t-shirts with the image of Che Guevara or Lenin are a common sight, there is a whole clothing line named "Prada Meinhof". These promoted products generate profit as part of the capitalist system, which Meinhof, paradoxically, once combated. What is left today in the collective memory is just the imprint and the gang's logo, yet, without any awareness or knowledge about the terrorist group and atrocities it committed. The traumatic experience of the 70s has been trivialized. The way the RAF is perceived may resemble the medieval image of Robin Hood who robbed the rich to give to the poor. This perspective is of less interest to politicians but remains an inspiration for those creating music, visual arts and plays. Despite the noticeably superficial, and possibly negative, reception, this should be considered a success, since this creative work points to the real role and meaning of this terrorist organization. It builds social awareness - not through a factual account though, but through a metaphorical narrative.

In Poland, the figure of Ulrike Meinhof has received particular attention. In 2006, theaters Usta Usta from Poznan and TR Warszawa, in cooperation with the Artistic Centre M25, announced a competition for the best play under a title: Being Ulrike $M$. The winning work was by Małgorzata Sikorska-Miszczuk, a playwright and scriptwriter. Her play, titled The Death of the Squirrel Man, ${ }^{12}$ is a grotesque piece, echoing the style of Monthy Python or the animated sitcom South Park.

The play by Sikorska-Miszczuk presents a vision of budding evil which originates precisely from a distorted idea and which transforms its followers into killing machines. However, violence returns to the protagonists and hits them twice as hard, leaving them only shadows of who they used to be. The presented story poses questions about the reasons and results of aggression visible in society, politics or the theatre. The play's central figure is the eponymous Squirrel Man. He is a lawabiding, hard-working and obedient citizen. He pays his taxes, worries about his loan and unwittingly supports the regime. He dies every day but then every day he is reborn, full of trust and love toward his tormentors. Just as in the real world, the terrorists show no mercy to their victims. The Squirrel Man has to suffer, for the common good. He represents the society which, especially at the beginning of

12 The text was published in a monthly "Dialog" no. 5, 2007. 
the 70s, admired the members of the Baader-Meinhof gang, secretly wishing they would have enough courage to follow in their steps. Germans were simply willing to compromise, happy to live their consumerist lives and create their everyday reality. A reality that was built on the harm inflicted on many nations.

Similarly as in Jelinek's work, here Ulrike and Ensslin also discuss the sexual aspect of their lives. Although Ulrike wants to renounce the physical needs, she admits that at nights she longs for their satisfaction. At the end of the play, Ulrike starts to be fond of the Squirrel Man. She confesses that she did not listen to him earlier, and smiles at him flirtatiously. At this moment it probably starts to dawn on her that something has gone wrong - that the fight she is fighting and the way it is handled are not right. Together with her victim they tie a rope which Ulrike plans to use to hang herself but eventually this does not happen. Instead, the Squirrel Man hangs himself with his tie, captivated with Ulrike till the very end. The RAF has more victims. One of them is a soft-hearted Policeman - he is later shot in his soft heart but at the end has a new one. Despite being repeatedly mocked and laughed at by Andreas Baader and both women, at the beginning he sides with the terrorists. He carries out his duties meticulously but at the same time smiles at the terrorists and chats with them. The Policeman is delighted to have the honor of arresting the famous Andreas Baader, a great thinker and visionary. At first, Baader introduces himself as a Anti-human, a person from whom no one and nothing can hide, an all-knowing being.

The author has thus in an interesting way demonstrated how the RAF terrorist attacks affected the police actions. At first, these were indeed limited. In the first years of its activity, the group had many supporters among academics and highrank figures. Meanwhile, after the Second World War German police did not enjoy much respect among the citizens, similarly as was the case in Poland after 1989. For Germans, a police uniform still cast the shameful shadow of the SS, SA and Gestapo officers. This possibly explains a certain slowness and clumsiness of the actions taken against the gang members. Only later, when the terror escalated and the number of victims increased, decisive steps aimed at reinforcing the system were adopted, this time with the full approval from society. Analogically, in the play the Policeman first expresses his affinity and admiration, only to be denigrated and later shot in the heart. Then, a new Policeman is born - with a new heart. And this one knows no pity or compassion. He performs a brutal X-ray on Ulrike and then locks her in a cage, as well as feeds Andreas and Gudrun the corpse of their political enemy.

The play by Sikorska-Miszczuk searches for the truth about the source of evil and about what lies hidden in the human soul. The Squirrel Man is not merely 
one of the RAF's victims - he is the sum of all victims, a society that is being experimented with. He believes in the lofty goals of the Baader-Meinhof gang and tries to understand what drives its members. However, after some time he realizes that something is wrong, something has failed. How can thus the world be healed if even such restrictive means have come to nothing? This question is addressed to every one of us and each of us has to find an answer to it on one's own. How do we want to protect ourselves against aggression and break the vicious circle of hypocrisy, of turning a blind eye on own sins and wrongdoings. The play does not dwell into the motivation of Ulrike, Andreas and Gudrun. It only prepares the ground for further discussions on aggression which lurks somewhere deep in every one of us.

Are we able to function without violence? As mentioned above, violence attracts people and many find it fascinating. The Baader-Meinhof myth would not be a lasting mass culture phenomenon if the same ideals were presented during peaceful protests. This is a recurring topic of the performance by Natalia Korczakowska, prepared at the Cyprian Kamil Norwid Theatre in Jelenia Góra in 2007. The spectacle is like a revolution, full of surprises and unexpected turns. It involves a play within play, with a multi-layered plot. On the one hand we witness theatre rehearsals, on the other hand - the story of Ulrike Meinhof (Lidia Schneider), Andreas Baader (Piotr Żurawski) and Gudrun Ensslin (Magdalena Kuźniewska). A new figure is also introduced - a rather shallow female director (played by Anna Ludwicka) who continuously tries to control what is happening at the stage. Korczakowska does not attempt to justify the use of force - be it in everyday life or in the theatre. She poses a question though: is there anything that is inherently evil and corrupted? She tries to compromise the myth of 'Prada Meinhof' precisely with a peculiar fashion show. The actors flirt with the audience just as the terrorists at first flirted with society. However, the aggression spirals and is incessantly re-enacted. The terrorists look as if they have just left the catwalk as well - they are hip, well-dressed, confident. This underlines how the legend of the RAF is depicted in the contemporary pop culture.

The presented portrayal of the German terrorist organization shows that dramatic art seeks to study and understand how a group functions. These works do not provide factual accounts or documentary view on the events. Their main purpose is examination of individual motives and their social impact. Theatre, being an intimate meeting between the artist and the audience, employs real events to create own narratives, precisely as in the case of the RAF story. While historians interpret the events, the stage becomes the place where legends are forged or demythologized. 


\section{Women's Tears - Dubrovka 2002}

The Chechen-Russian conflict dates back to the late eighteenth century, when Tsarist troops began to subjugate Chechen territories. The Russian determination to maintain domination after the collapse of the Soviet Union provoked a severe conflict that officially ended in 2002 in a victory for Russia which then introduced a normalization plan. The Republic of Ingushetia, while formally stabilized, continued to witness guerrilla warfare and terrorist attacks. Drive for independence as well as a sense of pride and freedom are characteristic of communities of the Caucasus. The right to self-determination gave rise to one of the most dramatic terrorist acts of the early $21^{\text {st }}$ century.

On 23 October 2002, a Chechen commando of 42 militants led by Movsar Barayev seized the Dubrovka Theatre in Moscow, with 800 spectators watching the musical Nord-Ost as well as 122 performers and staff members inside. Apart from Russians, there were several dozen foreign nationals among the audience. The terrorists planted explosives throughout the theatre, threatening to blow up the entire building unless Russia withdrew from Chechnya. On the third day of the siege, the Russian special forces stormed the theatre, having pumped unknown paralytic gas into the building shortly before the raid, which sedated the terrorists, rendering them unable to detonate the explosives. Apart from the Chechens, the operation left 130 hostages dead. The Russian government acclaimed the operation as a great success. ${ }^{13}$ Initially, it was not the theatre but the buildings of the State Duma and the Federation Council that were targeted for the onslaught, as admitted by Shamil Basayev, who had conceived the attack and trained the commando. The operation had been prepared since the spring of 2002. The choice of play was not a coincidence; it was symbolical, as the musical cheerfully evoked fond and nostalgic memories of the Soviet times. Prior to the attack, the terrorists conducted reconnaissance while attending other performances held at the theatre. Their equipment was perfectly prepared and could kill everyone inside. ${ }^{14}$

The incident has also a different, purely theatrical, dimension. Invoking the principles of performance art, one should note that the terrorist attack on the

13 As cited in: M. Wojciechowski, 57 godzin strachu, available at: http//www.gazeta.pl, accessed 21 December 2015; Theatre programme for Motortown by S. Stephens; Buchsteiner, Nordost, directed by G. Kania, Teatr Polski in Bydgoszcz, Bydgoszcz, 2007, p. 15.

14 Noteworthy publications on the 2002 Dubrovka theatre attack include: A. Zaucha, Moskwa Nord-Ost, Wydawnictwo Bosz, Olszanica, 2003, and M. Kuleba, Szamil Basajew: rycerski etos a powinność żołnierska, Fundacja Odysseum, Warsaw, 2007. 
theatre evolved into a particular kind of spectacle. The audience who came to see the play unknowingly became heroes of a wholly different piece. The terrorists directed a new drama, with the entire world watching in the belief that the tragic event would reach its happy ending. This is what served as the basis for a drama by Torsten Buchsteiner. A German actor, playwright and scriptwriter, he named his work after the musical staged on that fateful October day at Dubrovka, Nordost. However, it is not a musical spectacle, but an understated small-audience piece focused on presenting the characters and their motives; a close-up of the attack as seen from three different angles, three points of view, three pairs of tearful eyes. Three women, which was not a coincidence, given their involvement in the terrorist attack, of different social status and views became entwined by the drama of the place. Different reasons brought them there. Zura is a Shahid participating in the terrorist attack and a widow of a Chechen named Aslan. The second woman is Tamara, a Latvian-born internist, widowed by a Russian named Nikolai; she helps the victims of the attack. The third woman is Olga, a Russian accountant, married to a Russian named Oleg, who came to watch the play with her husband and daughter. While each story is unique and personal, they share certain similarities. All will become widows, and tragedy and despair is identical for all three women, regardless of their nationality and social status.

Zura used to be a laboratory assistant back in Chechnya. A Shahid with the same name was involved in the actual attack of October $23^{\text {rd }}, 2002$. She was Movsar Barayev's aunt, a widow and a strictest Muslim, who even did not reveal her face. The heroine, much like the majority of women from that region, got married very young; however, she was lucky to marry the love of her life. Her husband was gunned down by a Russian in Grozny in wartime. The trauma that she experienced was severe, her husband being everything to her; and not only because she loved him dearly, but also because a widowed woman is hardly worth anything in Chechnya. After being rejected by her husband's family and society, she met Sela, a long-lost friend of hers. Because of her, she became a terrorist. She was motivated by one thing only, and that thing was love. Chechen women tying explosives to their hips want to reconnect with their husbands, restore their honor and secure themselves a place in heaven. When her husband died, she experienced her own death as well. A sense of helplessness took her straight to the Moscow theatre. Deep in her soul, however, she wanted to live a normal life. The story of that Chechen demonstrates the everyday dilemmas of women struggling with the reality, which only seemingly is a realm of men.

Tamara is a doctor from Moscow. While she was born in Latvia, she lives in this city because of her Russian husband, Nikolai, who served in Chechnya. 
As a result of wartime bloodshed and atrocious reality, he could not cope with himself any longer, ultimately committing suicide. Her story illustrates to what degree a lack of physical intimacy and, most importantly, a lack of acceptance and reciprocity in a relationship may affect the human psyche. Every woman wishes to be satisfied, which includes intimate sensations, although it may sometimes cause embarrassment.

Olga enjoys the most settled life of the three, working as an accountant and, like thousands of other Moscow women, living a simple life together with her beloved husband and daughters. The play is a long-awaited event for her, and an important moment for each family member. Her marriage is peaceful and based on trust and mutual respect. Dedication to her family is the joy of her life rather than great sacrifice.

The tragic events of the Moscow theatre unite the anonymous women in spite of many differences between them. The strength of the drama manifests itself in how it shows that while people may be different, they all react identically and experience the same when their loved ones' lives are at stake. After the peaceful initial part, full of melancholic reflection and reminiscences, the true spectacle begins. Surprise and disbelief among the audience is striking; initially, it is neither fear nor hate. Who are the terrorists? For Muscovites, the war in Chechnya is a remote campaign, which, according to official communications, has been concluded. The play brings a clash between the two sides, the oblivious Russians and the resentful Chechens. They do not understand each other, with words unspoken and silent mutual accusations, signaled by nothing more than meaningful glances, permeating the atmosphere. No one feels understood. The spectators are terrified, having no idea of what is expected from them and what they have to do with all this anyway. The problem remains, however, that it is impossible to tell the villain from the innocent. People believe that they are safe at home and, again, their sense of security is shaken. A crucial issue addressed by the play is shame, a human reaction. Both the shame of a woman, when Barayev demands that Zura take off her chador, and the shame of physiology, when the hostages need to relieve themselves into the orchestra pit. In order to do so, they have to stand in a long queue and endure other people's stares. A person is thus subjected to humiliation and animalization.

In Nordost, the author raises an important problem of humanity. One may ask: where does the fight end? Where are the boundaries for the fight against terrorism and the fight for freedom? The conclusion one may arrive at while watching the play is hardly optimistic. Human nature is so cruel that there is no such boundary. There is always someone for whom the other person means nothing. One of the central issues of the drama is the fight for another person; both the fight during 
the theatre attack and the struggle put up by Tamara for her husband's acceptance. The women fight for their husbands and children. At that moment, nothing is more important, even their own lives. Looking closely at the terrorists, one can notice that women are those who are ready to make the ultimate sacrifice. Men, conversely, have an escape route planned. The drama shows women who, in the name of Allah, are ready for the ultimate sacrifice and for 12 months had been trained to lay down their lives. A woman who fights for her loved ones thinks of nothing else, being entirely devoted to the fight, and fights until the end. Like Tamara, who fought for her daughter Tanya and her mother; like Olga, who fought for her husband and her daughter Maya; like many other women on that day. This is often a lost fight, but the fighter does not surrender. Many people died upon the raid, children included. Although the separatists released foreigners, they did not want to free children. Twelve-year-old boys were once taken by Russian troops; likewise, Russian children were to suffer punishment for government policies. Most of them had been separated from their parents and located in the upper circle. Thus, given the chemical agents used by the special forces in the raid, many of them were saved, as the heavier gas did not manage to make its way to the balcony so rapidly. Eventually, almost two days into the siege, it became clear that the attack from which the Chechens were supposed to benefit became a trap. The men were prepared for the escape, while the women had no idea what to do, being entirely objectified. They have been exploited, no one was going to care about them. Zura took it very personally, as treachery. This bitterness and disappointment gave her strength to run away and take revenge on Movsar, who seemed very close to her not a moment ago. As the Russian Spetsnaz proceeded to pump the gas into the building, she gave in to panic and started to fight for her own freedom. The final scenes are truly abrupt, with the entire play gaining momentum and spinning fast. After the special forces rush into the building, the execution follows, no captives spared; the order was to kill the militants subdued by gas and show no mercy to those who were still conscious. Tamara is looking for her daughter and mother. She no longer suppresses her emotions, looking for what is dearest to her - her loved ones. The epilogue poses the question whether the special forces were right in their actions. Once again, Russia has proved that it will yield to no one. The Russians, in turn, will not be able to rise from their knees for a long time. It would appear that the "Black Widows" took their revenge. Russian women lost their husbands and children. More women to be widowed and more tears of suffering to be wept.

Buchsteiner's play constitutes a very realistic image of what transpired in the Dubrovka theatre in October 2002. The author incorporated memories of those 
who took part in the attack. It is a classic theatre of fact, where the real events have only been minimally amplified by the author's fiction. Rather than recount the events themselves, it presents an account of feelings accompanying the attack. We are looking at the same event through the eyes of a terrorist, a hostage and a rescue worker. Three women, three equal stories and the same pain caused by the loss of love. With all the differences in character and experiences, the ability to experience feelings is similar. Initially, the narrative is cold and distant. As the story unfolds, it continues to gain momentum until it becomes a cry of women entangled in the terrorist attack. In Buchsteiner's play, a woman is a reflection of the entire society. We believe that the husbands are the victims, but for terrorists those who die are only a means to inspire panic and fear. Victims are not those who lose their lives, but those who survive and must live with the trauma. That women are heroes of the play is not a coincidence, as they are capable of bringing out the deepest meaning of tragedy, the social pain, not to mention the political causes and effects. A view on violence and aggression gains greater sharpness. The questions posed concern morality of some moves, the ethic behind actions of policymakers rather than technical means. One can see the simplicity of the motives that drive the women when they rescue others, make sacrifices or take revenge. It is a story about love, despair and pain.

In Poland, the task of staging the play was taken on by Grażyna Kania at Bydgoszcz Polish Theatre. The play premiered on November 23 $3^{\text {rd }}, 2007$ as part of the project entitled Terrorism/The Prisoners of Despair. A theatre without theatre, a minimalist performance, it offered the audience a matter-of-fact account and rhythmical monologues. The first part features three displays and a dry account from three women. Each tells her story, complementing one another, thus allowing the audience to understand their message. Actual acting is only introduced in the second part. Kania primarily shows people, their emotions and feelings, rather than a problem of the contemporary world, namely the Russian-Chechen conflict. A depiction of the issue of terrorism, unfamiliar to most spectators, was combined with what everyone could relate to, i.e. the feelings of commitment, anxiety, regret, fear and anger - emotions experienced by people who are intimate with each other. The spectacle terrorized the audience, forcing them to listen to the three women and their stories; making them reflect on their own sense of security, which turns out to be, in fact, very shaky. It is a psychological drama which appeals to the deepest and simplest impulses behind human actions. The audience are being emotionally blackmailed and forced to feel, at least for a while, as if they have lost everything of value in life.

A woman as a victim and a culprit, the entanglement of feelings and individual sensations become one of the most interesting artistic experiences when it comes 
to employing a terrorist act in the theatre setting. Pain and tragedy of the individual participants of the events deeply affected the audience. In a quiet theatre room, the voice of three women for whom love and sacrifice means more than life revealed the trauma of a terrorist attack.

\section{Terrorism and Pornography}

Thursday, July $7^{\text {th }}, 2005$ shook London with a series of terrorist attacks that occurred on public transport. The suicide bombers were British citizens; three of Pakistani descent and one Jamaican. They all came from the industrial city of Leeds in West Yorkshire, Northern England. It is a very peculiar city. Of all ethnic minorities, the Pakistani account for a staggering 40\%. Despite a well-developed manufacturing sector, almost a half of these people are unemployed, the reason being predominantly a lack of relevant experience. Each of the attackers grew up in penury; it follows that a certain kind of isolation, a lack of prospects and the stark contrast in the standards of living in Britain led those practicing Muslims to confront their reality. Britain does not pursue any detailed minority assimilation policy. Certainly, a major cause behind the 2005 attacks were the international affairs as well. A shift in policy following the September 11 attacks on the WTC resulted in the 2003 invasion of Iraq and intensified operations in Afghanistan. Many European Muslims fell victim to false accusations, profound distrust and derision. Such treatment, as in many other situations where worship is threatened, prompted Muslims to improve their knowledge of the Quran and deepen their perception of faith as well as to strictly observe the top-down principles of religious conduct. This time, a sense of alienation from the particular community triggered off the massacre of July 2005.

The four young suicide bombers are commonly referred to as the new independent generation of Al Qaeda, the so-called third generation. A Scotland Yard investigation helped establish the identity of each of the suicide bombers. The mastermind behind the operation was the 30 -year-old Mohammad Sidique Khan, who also recruited the remaining three men to carry out the attack, Shehzad Tanweer, Hasib Hussain and Germaine Lindsay. ${ }^{15}$ While preparing the attack, they travelled to Pakistan and studied the Quran assiduously. One should note that their communities pointed out that each of the attackers had undergone a deep spiritual transformation as regards their life and behavior prior to the bombings.

15 W. Dietl, Terroryzm...op.cit., p. 163. 
Their conduct had diametrically changed, and this re-evaluation resulted in the objective they accomplished on 7 July 2005.

Britain seems to be a country where confrontation with violence is not a distant topic. The combat against Irish extremists has continued for decades. That was not the first time when London witnessed bombings. Yet, despite all the experience and apprehension about the possible strike as a consequence of the British involvement in the anti-terrorist coalition, the attack came unexpected. The main targets were the London Underground network and a city bus. In a time of euphoria and glee, which the Londoners experienced after their city had been declared host of the 2012 Olympics, the trauma of a terrorist act crept in. The timing was perfect, the aim being to intimidate society and appear in the media. Executed in no time, the attack brought four explosions on public transport within an hour; three bombs were detonated on the underground and one on a double-decker. Responsibility for the attack was claimed by a previously unknown Al Qaeda group, the Secret Organization of Al Qaeda in Europe. Devised in response to the British engagement in Afghanistan and Iraq, the attack took 57 lives and left 700 people wounded.

The 7/7 bombings provided the setting for Pornography, a play by Simon Stephens (b. 1971), a British playwright and one of the most interesting younggeneration writers of the time. As noted by the author, "the play arose from a deep doubt in our culture, from the observation of chaos in which we live: not from honesty." ${ }^{\prime 6}$ The drama reflects on what people feel, how to reconcile the knowledge of being alive with the knowledge of death. The terrorist attacks recede into the background, being only a distant echo in everyday life. While affecting individuals, their attitudes and relationships, they are not the main subject of the play, which is full of convoluted thoughts, reminiscences, random dialogue and words left hanging in the air. Unwittingly, we begin to spy on people and their dilemmas. Out of this nonsense, we start to recognize figures, distinguish contours, and define the existing order of things. For the author, information overload, being an inherent part of the contemporary media, has become a reflection of the modern society and human relations. The information revolution witnessed in recent years has significantly depleted our reservoir of ways to communicate. Nowadays, our conversations resemble a fast food meal; they are simple, quick, superficial, and very bland. Idleness and freeloading, so prevalent these days, have caused those meals devoid of nutritional value and those bland and colorless conversations

16 As cited in the Programme for the spectacle by S. Stephens, Pornography, directed by a team of directors, Teatr Dramatyczny in Warsaw, Warsaw 2008. 
to become the norm. Simon Stephens sees a great similarity between those conversations and the eponymous pornography. Vulgar and hackneyed formulae, conversations without depth, instant satisfaction of simple needs; this is what conversations now look like, not only between colleagues at work, but also between relatives, married couples and friends. In this hectic world, there is not a moment of respite for a deeper reflection. Our existence comes down to a mere consumerist indulgence of the body, with spiritual fulfillment becoming a rarity of secondary importance. One may venture to call them "controlled conversations."

The play was written after the London Underground bombings, when the British capital, only just intoxicated by the vision of the 2012 Olympics, suddenly lost stability of everyday life. Society had to redefine its sense of security and reflect on the London events. The heroes are random people who, just as anyone, at the time of 7/7 were struggling with problems of everyday life. Snatches of conversation, while seemingly lacking emotional involvement or sense, are in fact filled with incomprehension, longing, and sometimes sorrow. The play itself is extremely flexible, allowing for any number of actors on stage, which only proves that it is a social analysis rather than a story about specific people. The first piece of dialogue introduces a young couple. Both avoid being honest, and they do not understand each other. Their replies are either arrogant and aggressive or terse. In the next scene, we see a mother. This is the character on whom the author focused most. Once again, a woman was given a central role in a drama. Her words emanate sadness and weariness. Her monologue is substantially more emotional than the preceding dialogue, and yet there is something missing. What is absent is closeness of another person, the father of her child. One can hear her quivering inside, slightly overwhelmed in a rush of everyday matters. The problems emerging in her life are brushed aside and masked with ordinary, trivial everyday concerns. However, she cannot abandon the feeling of suspicion and distrust toward her partner Johnathan. Every day she goes to bed beside him, and yet she does not trust him and cannot muster enough courage to have a candid conversation with him. The completely unrelated strands of thought are intersected by the reflections of her entire relationship, devoid of trust and understanding. The only actual joy in her life is her son, who nonetheless cannot offer her support and with whom she cannot talk. Although she is not alone, she is very lonely. The third act introduces a young half-Italian boy, who lives with his parents and his elder sister. Undergoing puberty, feeling neglected by his family and misunderstood, he is a typical teenager of today. Fascinated by a school teacher, he neglects his education. A sense of being misunderstood, a lack of stabilization, possibly including financial instability, spark his aversion to ethnic minorities he encounters at school 
and in the street. There is no place for an open conversation at his home, with his mother sidestepping his questions about his father's violence toward her. They pretend that there are no problems, in the false hope that those will simply fade away. The boy's aggression and anger well up; he does not feel masculine enough and attempts to comfort himself by imagining his power. He retreats into his own world. Then, one day, as he enters the underground with his sister, he finds himself standing next to a boy with a rucksack, the bomber. Thus unfolds a scene of hell, a scene filled with silence. There is also a story of an incestuous relationship. Another couple cannot get along with each other, yet they maintain sexual relationship, seeking physical closeness, since spiritual intimacy is out of their reach. Thousands of people, thousands of problems, reflections and emotions. Everything is incoherent, imprecise, beyond comprehension. What can be sensed, however, are human emotions: anger, sadness, sorrow. When the attacks come, there comes fear. All of a sudden, it turns out that despite the persistent feeling of loneliness, everyone becomes worried about someone, and panic begins to creep inside. A man on a train suddenly feels the need to talk to his wife, make sure that his children are not late for school. Then comes another scene that shows London shortly after the bombings. Everything is calm and quiet. The city seems desolated, a rare view in London. Most amazingly, among this chaos, disorientation and panic sweeping through the city, two people manage to plant a seed of understanding, a feeble sign of healthy communication based on positive human emotions. Each person is full of dilemmas and problems, which represents the contemporary world, brimming with words unspoken and emotions concealed.

\section{Conclusion}

The view on culture we have come to live in makes us doubt whether humanity's internal development keeps pace with technological progress. Superficial conversations are held properly. Somewhere deep down, however, the true emotions are repressed. At the moment of the catastrophe, the barrier cracks slightly, but does not break down completely. The fact is that only some people are able to overcome it. The world today resembles a crystal ball which, granted, does look impressive, but it effectively separates us from the rest, isolating us completely.

Terrorism sobers us up, offering food for thought and acting as a catalyst for certain changes that man needs to undergo in order to heal the entire society. The terrorism presented in Stephens' drama is a background, on which the author raises questions about ourselves. What is crucial this time is the attitude not toward the attack or the attackers, but toward the loved ones. Wondering what the everyday reality looks like in this fast-paced world, and whether one event can 
upset what society has laboriously built, the author asks about the things that are most important to us at the moment. In pursuit of material well-being, people irrevocably lose the ability to communicate with each other. One-time shock cannot change and redefine everything, but it certainly is a slight impulse to stand back and reflect on oneself.

The analyzed contemporary dramas show terrorist attacks being used to build autonomous artistic universes. The stories are not simple accounts of events. Brought to the fore is the human being, their motivations, feelings, thoughts and communication with another person. The contemporary drama, in reaction to what reality brings is trying to observe it, yet remains far from being a mere commentator. Authors become creators of our human worlds, for each of us may fall prey to this $21^{\text {st }}$ century plague - a terrorist attack.

\section{References}

E. Borowska, Obraz terroryzmu w europejskich dramatach XXI wieku, an essay under an academic supervision of D. Przastek. Warsaw 2011.

W. Dietl, K. Hirschmann, R. Tophoven, Terroryzm, Wydawnictwo PWN, Warsaw 2009.

Ł. Drewniak, E. Wójciak, Z. Jakubowska, G. Laszuk, M. Liber, Jak nie być Ulrike Meinhof. "Dialog" no. 5, 2007.

V. Grotowicz, Terroryzm w Europie Zachodniej. W imię narodu i lepszej sprawy, Wydawnictwo PWN, Wrocław 2000.

A. Krzemiński, Dzieci Hitlera?, "Dialog”, no. 5, 2007.

M. Kuleba, Szamil Basajew: rycerski etos a powinność żotnierska, Wydawnictwo Fundacja Odysseum, Warsaw 2007.

J. Minałto (ed.), Kronika wypadków cenzorskich. Ostatnie lata, "Notatnik Teatralny" no. 39-40, 2006.

E. Piscator, Teatr polityczny, Wydawnictwa Artystyczne i Filmowe, Warsaw 1982.

R. Schechner, Performatyka, Wstęp, Ośrodek im. Jerzego Grotowskiego, Wrocław 2006.

S. Semil, M. and E. Wysińska, Słownik wspótczesnego teatru. Twórcy, teatry, teorie, Wydawnictwa Artystyczne i Filmowe, Warsaw 1990.

M. Tomczak, Terroryzm w RFN i w Berlinie Zachodnim, Instytut Zachodni, Poznań. 1986.

A. Zaucha, Moskwa Nord-Ost, Wydawnictwo Bosz, Olszanica 2003.

Programme for the spectacle by S. Stephens, Motortown. Buchsteiner. Nordost, directed by G. Kania, Teatr Polski in Bydgoszcz, Bydgoszcz 2007. 
Programme for the spectacle by S. Stephens, Pornography, directed by a team of directors, Teatr Dramatyczny in Warsaw, Warsaw 2008.

\section{Dramas and plays:}

T. Buchsteiner T., Nordost.

M. Sikorska-Miszczuk M., Śmierć Człowieka-Wiewiórki.

S. Stephens S., Pornography. 


\section{Notes on Contributors}

Hallar Abderrahaman Mohamed - PhD Student in Law and Social Change at the University of La Rioja. Master's degrees in Equality and Gender/Culture of Peace, Conflict, Education and Human Rights/ in teaching secondary School and professional training. Expert degree in Social Work, Degree in Social Work, Bachelor in Social Work. She has experience working in NGO as social worker in the humanitarian aid program for immigrants, asylum-seekers and refugees from Syria.

Elżbieta Borowska - PhD at the Faculty of Journalism and Political Science, University of Warsaw, graduated in internal security at the University of Warsaw. She conducts research about the protection of cultural heritage and cultural politics. Polish politician, member of polish Parliament and member of the Committee of Culture and Broadcast Medium.

Claribel de Castro Sánchez - PhD at The National Distance Education University (UNED) in 2004 and undergraduate studies at Complutense University of Madrid in 1996. Is Lecturer in the Department of International Law at UNED where she has been a faculty member since 1998. She has been involved in the Master on Security and Master on European Union, developed in the UNED, and in Master on the Challenges on Peace, Security and Defense, developed by the Instituto General Gutierrez Mellado. In these moments, she participates as teacher and Module Convenor in two European Joint Master Degree Programs with CEPOL and FRONTEX. In recent years, she has focused on International Law of Human Rights and Security Matters. Her research interests lie in the areas of International Law and European Union Law. She has written several papers (books, chapters and articles) in these matters. She has collaborated in national and international research teams. In 2004, she was distinguished with the Defense Award-given by the Spanish Ministry of Defense for her work.

Fanny Castro-Rial Garrone - PhD of Law at the Complutense University of Madrid. High Studies of Defense Diploma. Is permanent Lecturer of IS International Public Law and International Relations, director of the University Institute for Domestic Security Research, established by the National Distance Education University (UNED) and the Civil Guard, coordinator of the UNED Law School Security Masters and professor at the Spanish School of Diplomacy. Author of 
publications, among others, on Maritime Security, Immigration, International Protection of Human Rights and International Administration of Territories. Honors: Civil Merit Commendation of the Foreign Office, Silver Civil Merit Cross of the Civil Guard

Pablo de Diego Angeles Ángeles - $\mathrm{PhD}$ in Law at the National Distance Education University (UNED) (Doctoral thesis about Wealth and Estate taxes in a comparative frame). Degree in Law 1972-1977. Postgraduate exam ("Grado de Licenciatura”, Thesis for Degree purposes) in Law, November 1977, University of Santiago de Compostela. Since 01/11/1981: Different categories in University professorship. Now he is Professor Titular (Senior Associate Professor). Deputy to Dean School of Law, since November 2004 until now. His develop as Professor is now in the Department of Public Finance, Economics of the Public Sector and Public Management (School of Law UNED). Recent Publications: "La acción y los retos del Sector Público" Editorial Delta, Madrid 2005, Manual de Derecho y Fiscalidad Inmobiliaria, Editorial Jurist\&Law Editorial, Madrid, 2008. Public Management in a Crisis context. Editorial Universitas Madrid 2014. Several publications in Tax Law reviews in Spain (Crónica Tributaria. Wealth local taxes in Spain, Inheritance Taxes in Comparative Law, 2013). Article The Housing Right as Human Right in International and Comparative Law (review of the Political Science Institut in Warsaww, 2014).

Magdalena Dobrowolska-Opała - PhD student at the Faculty of Journalism and Political Science, University of Warsaw, graduated in internal security at the University of Warsaw. She is a certified steward, director and co-founder of the Doctorals' Research Association of Social Science. Her research interests focus on the topic of the role of police forces in providing safety and security during football matches. In 2015 she took an internship in one of the football clubs in England.

Juan Manuel Goig Martínez - Professor holder of Constitutional right accredited by ANECA. He is a Professor of constitutional law and teaches in several masters in Spain and in several countries in Latin America such as Dominican Republic, Venezuela, Colombia, Bolivia and Ecuador. It is a member of the consolidated research group of UNED "Aliens and migration", and for two years was its Director. Author of several books dedicated to the Constitutional right. Has published is the two monographs on rights and freedoms of migrants in Spain. His research interests are: rights of immigrants, asylum and refuge; rights of minors; administrative divisions of the State and constitutional jurisdiction. He has participated in several collective works and is the author of numerous articles in high impact journals. 
Teresa Marcos Martín - PhD of Law at the National Distance Education University (UNED). Professor of International Public Law. International Law Department. UNED. "Vice Secretaria General Técnica". UNED. Lecturer of Public International Law and European Law at several Institutions (Spanish School of Diplomacy, Instituto Superior de Derecho y Economía, University of Santander, University of A Coruña). Publications: Multiple articles, papers on European Union Law (Institutions, European Court of Justice, Competition Law), International Protection of Human Rights (Children's rights, freedom of expression). Member of several R \& D Projects.

Ángeles Martínez Boyé - PhD from UCL: Doctoral Program: Social Dialogue in Europe. Department of Social Labor and Employment Law. Degree in Law from the at the Complutense University of Madrid (UCLM). Master's Degree in Integrated Quality, Environment and Occupational Risk Prevention, UNED. Degree in Social Work from the University of Granada. Accredited by the ANECA as Contracted Doctor. Assistant Professor Doctor at the Faculty of Law, UNED. Professor of Master of Social Intervention and Gender Violence (Faculty of Law) and Master of Social Problems (Faculty of Sociology and Political Science) UNED. Coordinator of Social Work degree. Career for more than 11 years in the field of social work practice in the Ministry of Social Welfare of the Regional Government of Castilla La Mancha. Co-author of several books, chapters and related research and career articles. Research interests: Gender and European Social Cohesion. "Welfare State-New Social Pact".

Andrzej Misiuk - Professor of humanities, head of Chair of Security Studies in the Institute of Political Science, University of Warsaw. His academic specialty is the study of internal security, especially the history of police institutions and special services in Poland. He is also interested in internal security systems at national and European level. He participated in the work of the editorial committee Police Review and Internal Security, he is a member of the International Association of Chiefs of Police. He is the author of the first monograph on the history of the special services in the Second Polish Republic.

María Acracia Núñez Martínez - Professor of Constitutional Law. Vice- Dean of Academic and Institutional Relations management. Member of the Council of Government of the UNED. She lectures the Constitutional status of the foreigners and the protection of the rights of immigrants; International Constitutional Rights and human development; International Mediation and Arbitration; rights of foreigners, constitutional, legislative and jurisprudential delimitation. Comparative 
Law Member of the research group Immigration and Migration. She has published two monographs and more than twenty articles.

Jesús Pérez Viejo - PhD in Social Work, Degree in Psychology. Master’s degrees in Social Work, Sexuality, Prevention of Gender Violence and Victims' Comprehensive Care. Expert in Psychological intervention with aggressors. Actually Assistant Professor at Carlos III University, Department of Social Analysis. Formerly an Associate Professor at the National Distance Education University (UNED). Over 15 years of experience in the NGO sector, developing key coordination and management functions. The last years has been working as Director of the Aspacia Foundation for Coexistence, specialized in fighting violence in all its forms as well as protecting victims and promoting equality in relationships, supervision, coordination and implementation of programs and research projects, dissemination, awareness and training of professionals and general public on violence-related issues. Coordinator and co-author of the books "Gender Violence: prevention, detection and treatment" and "Perspectives on Gender Violence".

Piotr Potejko - Advisor to the Head of the Internal Security Agency, assistant professor and lecturer at renowned universities and author of publications in the field of security, terrorism and crisis negotiations. Holder of a PhD in Philosophy, lawyer, pedagogue. Long year assistant professor at the Faculty of Law and Administration at the Adam Mickiewicz University in Poznań, currently assistant professor within the Chair of Security Studies at the University of Warsaw. Awarded the Minister of National Education prize for his scientific work. His scientific work is connected to deepening knowledge in the field of the internal and of the international security of the state. Participant of the work of the Foreign Affairs Committee of the Polish parliament as regards international agreements relating to information security. Representative of the Prime Minister in the area of proceeding and initialing international agreements and representative of Poland during meetings of NATO and EU Security Committees. Author of publications, among others, on special pedagogics, Polish intelligence services, terrorism. Editor in chief of the Przeglad Bezpieczeństwa Wewnętrznego (Internal Security Review), as well as Deputy Chair of the Internal Security Institute in Poznan and honorable cofounder of the Polish Association for Supporting National Security (SWBN).

Anna Potyrała - political scientist, lawyer, professor at the Department of International Relations of the Faculty of Political Science and Journalism at Adam Mickiewicz University (AMU). Member of the Polish Society of Political Science 
(PTNP) and Polish Society of International Studies (PTSM), board member of the Poznan branch of the latter. Assistant editor in the academic journal "Przegląd Strategiczny" ("Strategic Review"), member of the editorial board of the journal "Przegląd Zachodni” ("Western Review"). Her research focuses on involuntary migration, public international law, international criminal law and the area of justice and home affairs of the EU. Author of several monographs, the most recent: UN towards the refugee problem. Genesis, concept and practice of activities (Warsaw 2015).

Daniel Przastek - holder of a PhD in political sciences (2004), playwright and theatre artist. Academic researcher at the Institute of Political Science at the Faculty of Journalism and Political Science of the University of Warsaw, deputy director of the Institute, responsible for academic affairs and international cooperation. Holder of a scholarship awarded by the Polish Cultural Foundation in Buffalo (USA). In his work he focuses on modern history of Poland and of the world. His professional interests include also relations between art and politics, with particular emphasis on the relations between theatre and politics. Author of the book titled Srodowisko Teatru w Okresie Stanu Wojennego (The theatre circles during the martial law in Poland). Author of several dozen articles, both scientific and popularizing science. His works were published in: Notatnik Teatralny, Opcje, Przeglad Powszechny, Teatr, Nietakt!, Rocznik Nauk Politycznych, Świat i Polityka, Przegląd Europejski, Społeczeństwo i Polityka, Dzieje Najnowsze, Studia Politologiczne. He cooperated with directors Michał Zadara, Marta Streker and choreographer Krzysztof Pastor in productions at the Theatre Institute in Warsaw, Teatr Wielki-National Opera, the Warsaw Rising Museum, Teatr Nowy in Łódź, Teatr Polski in Wrocław, Z. Hübner Teatr Powszechny in Warsaw and Teatr Polski in Warsaw. Co-founder of theatre festivals and leader of the student theatre movement.

Anna Sroka - Assistant Professor at Institute of Political Science's within the Chair of Security Studies at the University of Warsaw. Graduate of the Institute of Political Science at Wrocław University (2001), where she also completed her $\mathrm{PhD}$ at the Institute of International Studies (2006). Received her habilitation from Warsaw University (2015). Lecturer at the Antonio de Nebrija University and the National Distance Education University (UNED). She has undertaken scholarship study visits at the Free University of Berlin, the Autonomous University of Madrid and the University of Trieste. A member of many scientific organizations, such as PTNP, AECPA, IPSA and ECPR. She is a member of the board of the IPSA "Quality of Democracy" scientific committee, coordinator of the Polish-Spanish 
Scientific Research Network, and a member of the ECPR Executive Committee. She has participated in numerous domestic and international research projects, including. Her research interests concern various aspects of quality of democracy, both at the domestic and the international level, with particular attention paid to the issues of inter-institutional and electoral accountability. She is the author of numerous articles, as well as co-editor and author of several books. Her most recent work is Accountability in Studies on Quality of Democracy on the Example of Poland and Spain, Peter Lang, Frankfurt am Main, 2016.

Stanisław Sulowski - Professor of Political Science at the University of Warsaw and Director of the Institute of Political Science at the same University. For the past six years he has been the manager of the University of Warsaw Think Tank: Centre of Political Analysis. Professor Sulowski is editor of the Studia Politologiczne (Political Science Studies) quarterly and editor of the book series published by Peter Lang Verlag: Studies in Politics, Security and Society. He is also Member of the Committee of Political Science of the Polish Academy of Sciences. He has served as Consul of the Republic of Poland in Germany, 1991-1995. His academic research focuses on German foreign policy, state theory, European integration and internal security. He has received several scholarships and had teaching assignments in Germany, Russia, Austria and Ukraine.

Damian Szlachter - PhD student at the Police Academy in Szczytno, civil servant, former employee of the Ministry of Foreign Affairs, the Prime Minister Chancellery, the Ministry of the Interior and one of the Polish law enforcement agencies, author of the book "The fight against terrorism in the European Union - new impetus", co-author of two other publications: "The radicalization of religious views in Muslim communities in selected EU countries (Poland - Netherlands United Kingdom)" and "Anti-terrorist information strategy". The author of several articles in magazines such as: Internal Security Review, Terrorism, Police. Head of the research project: "The prevention and counteraction of the phenomenon of religious radicalization among Muslims living in Poland - as a part of a national system for early detection of terrorist threats".

Rubén Darío Torres Kumbrián - PhD at Doctoral Program of Community law and European Union, Centers for European Studies at the Complutense University of Madrid (UCLM), and PhD by the UCLM at Doctoral Program in Employment, Industrial Relations and Social Dialogue in Europe. He is Professor and Director of Department of Social Work, Faculty of Law, UNED. Master Teacher FRONTEX for the management and control of European borders, led to the formation 
control of the security forces of Member States of the European Union. Member of the Scientific Committee Studia Politologiczne (Institute of Political Science of University of Warsaw). He has received Francisco Corell Foundation Award: Theory of Social Control Traffic.

Katarzyna Trofimowicz - PhD student at the Faculty of Journalism and Political Science, University of Warsaw. Graduate of International Relations and Spanish Philology at the Jagiellonian University, scholarship recipient under the Erasmus programme at Universidad Pablo de Olavide in Seville. Research interests: international and internal security, security strategies of Poland and Spain, strategic culture, political systems, Spanish territorial system, the history and politics of the Autonomous Community of Andalusia, history and culture of Spain and the countries of Latin America.

Sebastian Wojciechowski - Professor at Adam Mickiewicz University in Poznań and the Institute for Western Affairs in Poznań. Head of the Strategic Studies Department of the Faculty of Political Science and Journalism of Adam Mickiewicz University in Poznań. Security expert of the Organization for Security and Co-operation in Europe. Member of the Scientific Board of the Centre for Research on Terrorism, Collegium Civitas. Editor in chief of the Przeglad Strategiczny academic periodical. Awarded scholarships by the Foundation for Polish Science and the US State Department. Recipient of the Scholar's Award from the Prime Minister of the Republic of Poland and an award for a scholarly publication in a European Union-wide contest. Author of publications, among others, on asymmetric threats, global problems, security, international relations, terrorism, nationalism, and the Balkans. He is the author, or co-author, of, e.g. The Faces and Problems of Modern Europe. Case Studies, (ed. with J. Jeszka) Poznań 2010; Poland's Security. Contemporary Domestic and International Issues, (ed. with A. Potyrała), Berlin 2013; Relations Between The European Union and Egypt After 2001 - Determinants, Areas of Co-operation and Prospects, (ed. with A. Potyrała and B. Przybylska-Maszner), Berlin 2015. His most recent publications are: The Hybridity of Terrorism, Berlin 2013 and Understanding Contemporary Terrorism and Counterterrorism, (with A. Sadkowski), Dąbrowa Górnicza 2014. 
